\title{
SINGAPORE IN \\ GLOBAL HISTORY
}

Edited by

Derek Heng and Syed Muhd Khairudin Aljunied 
Singapore in Global History 


\section{icas Publications Series}

\section{General Editor}

Paul van der Velde

\section{Publications Officer}

Martina van den Haak

\section{Editorial Board}

Wim Boot (Leiden University); Jennifer Holdaway (Social Science Research Council); Christopher A. Reed (The Ohio State University); Anand A. Yang (Director of the Henry M. Jackson School of International Studies and Chair of International Studies at the University of Washington); Guobin Yang (Barnard College, Columbia University).

The ICAS Publications Series consists of Monographs and Edited Volumes. The Series takes a multidisciplinary approach to issues of interregional and multilateral importance for Asia in a global context. The Series aims to stimulate dialogue amongst scholars and civil society groups at the local, regional and international levels.

The International Convention of Asia Scholars (ICAS) was founded in I997. Its main goals are to transcend the boundaries between disciplines, between nations studied, and between the geographic origins of the Asia scholars involved. ICAS has grown into the largest biennial Asia studies event covering all subjects of Asia studies. So far six editions of ICAS have been held respectively in Leiden (I998), Berlin (200I), Singapore (2003), Shanghai (2005), Kuala Lumpur (2007), Daejeon, South Korea (2009) and Honolulu, Hawai'i (2011).

In 200 I the ICAS secretariat was founded which guarantees the continuity of the ICAS process. In 2004 the ICAS Book Prize (IBP) was established in order to create by way of a global competition both an international focus for publications on Asia while at the same time increasing their visibility worldwide. Also in 2005 the ICAS Publications Series were established.

For more information: www.icassecretariat.org 


\section{Singapore in Global History}

Edited by

Derek Heng and Syed Muhd Khairudin Aljunied

AMSTERdaM UNiversity Press 
icas Publications Series

\section{Edited Volumes 14}

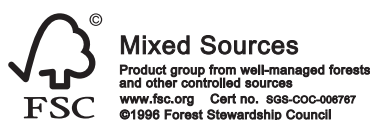

Cover design: JB\&A raster grafisch ontwerp, Westland Layout: The DocWorkers, Almere

$$
\begin{array}{ll}
\text { ISBN } & 9789089643247 \\
\text { e-ISBN } & 9789048514373 \\
\text { NUR } & 692
\end{array}
$$

(C) ICAS / Amsterdam University Press, Amsterdam 20II

All rights reserved. Without limiting the rights under copyright reserved above, no part of this book may be reproduced, stored in or introduced into a retrieval system, or transmitted, in any form or by any means (electronic, mechanical, photocopying, recording or otherwise) without the written permission of both the copyright owners and the authors of the book. 


\section{Table of Contents}

$\begin{array}{ll}\text { List of Tables and Illustrations } & 7\end{array}$

Foreword 9

I Globalising the History of Singapore II

Syed Muhd Khairudin Aljunied Q Derek Heng

$2 \quad$ Situating Temasik within the Larger Regional

Context: Maritime Asia and Malay State Formation

in the Pre-Modern Era

27

Derek Heng

3 The Singapore River/Port in a Global Context

$5 \mathrm{I}$

Stephen Dobbs

4 'Walls of Illusion': Information Generation

in Colonial Singapore and the Reporting

of the Mahdi-Rebellion in Sudan, I887-I89o

Torsten Tschacher

$5 \quad$ The Littoral and the Literary: Making Moral Communities in the Straits Settlements and the Gold Coast in

the late Nineteenth and Early Twentieth Century

Philip Holden

6 Social Discourse and Economic Functions:

The Singapore Chinese in Japan's Southward

Expansion between I9I4 and I94I

III

Huei-Ying Kuo

$7 \quad$ The Dynamics of Trans-Regional Business and National Politics: The Impact of Events in China on Fujian-Singapore Tea Trading Networks, I920-1960 Jason Lim 
8 Rambutans in the Picture: Han Wai Toon and the Articulation of Space by the Overseas Chinese in Singapore

Lai Chee Kien

9 The Global Effects of an Ethnic Riot:

Singapore, I950-I954

Syed Muhd Khairudin Aljunied

Io The British Military Withdrawal from

Singapore and the Anatomy of a Catalyst

I95

Loh Kah Seng

II Bringing the International and Transnational back in: Singapore, Decolonisation, and the Cold War S.R. Joey Long

I2 The Global and the Regional in Lee Kuan Yew's Strategic Thought: The Early Cold War Years Ang Cheng Guan

I3 A Brief History of the Hub: Navigating between 'Global' and 'Asian' in Singapore's Knowledge Economy Discourse

Leong Yew

About the Contributors

Bibliography 


\section{List of Tables and Illustrations}

\section{List of Tables}

Table 6.I The distribution of Chinese sub-ethnic groups in Southeast Asia

Table 6.2 Importers and wholesalers of Japanese shoes in Singapore

Table 6.3 Chinese textile wholesalers and retailers dealing in Japanese cotton cloth, sarong and rayon in Singapore, I933

\section{List of Illustrations}

Figure 8.I Shen Nong Medical Hall at Bras Basah Road, now demolished (courtesy of Koh Nguang How)

Figure 8.2 Han Wai Toon, Marco Hsü and guests at the Han Rambutan Orchard (image courtesy of the estate of Marco Hsü)

Figure 8.3 Detailed sketch of the orchard by Lim Mu Hue (courtesy of the estate of Lim Mu Hue)

Figure 8.4 The "Han Rambutan Orchard" by Lim Mu Hue, I964, Chinese ink on sepia rice paper, 6' $\times 4$ '

Figure 8.5 A detail of Lim's painting showing Han's Inarch grafting method 



\section{Foreword}

The basic premise of this volume of articles is that there is a need to respond to the challenge issued by Jerry Bentley - one of the pioneers of the now well-established field of 'World History' - for historians to attempt both to 'globalize history' and to 'historicize globalization'. Though directed at historians, it is a challenge that raises broader questions about the interplay between the global and the local in all fields of endeavour. While the joint editors of this volume are both historians, the contributions are from specialists in history, political science, international relations, sociology, literature, art history and architecture, all of whom address this issue to a greater or lesser degree with regard to Singapore. A major aim of the contributors was to emphasise the contribution of the 'local' to the 'global'.

Since the late I990s there has been a proliferation of studies on Singapore. ${ }^{\mathrm{I}}$ Initially, these works were written by non-professional historians and government bodies responding to the government's call as part of the official I997 launching of the National Education Programme, which was intended to educate the people about the struggles that led to the success story that was Singapore's. The response included publications on the "Singapore Story", especially the memoirs of Lee Kuan Yew and biographies of other political figures, such as S. Rajaratnam, Lim Kim San, and David Marshall. This form of historical writing culminated in the 20I0 publication, Men in White. ${ }^{2}$ Professional historians then became involved not simply in producing the standard histories of the nation state of Singapore, but also in offering an alternative 'history from below. Of particular note is the 2008 publication entitled, The Scripting of a National History: Singapore and Its Past. ${ }^{3}$ There has also been a trend towards giving greater emphasis to Singapore's international involvement from its earliest history, which has been reconstructed through archaeological finds, to the present day. The most recent example, published in 2009, is simply entitled Singapore: A 700-Year History, ${ }^{4}$ a book which discusses Singapore's position within a wider regional and global context.

This volume continues the latter trend by arguing that much of what has occurred in this island state is the result of powerful global forces that were adapted through local agency. A subsidiary theme is the re-assessment of Singapore history not as the story of 'big men and major 
events' but of the ordinary and the prosaic, which together provides an alternative version of the past. It eschews the laudatory tone adopted by some previous works on Singapore, which stress the nation's remarkable economic success in the world. Instead, it situates Singapore within a larger picture as one of many societies attempting to cope with the global movement of a vast number of peoples, ideas, and businesses. Here Singapore is not viewed as an isolated community with unique problems and solutions, but as a society that is always responding and itself contributing to rapid changes fuelled by an explosion of information made possible by the latest technology.

Singapore in Global History is a testament to the increasing sophistication displayed by those now engaged in reconstructing Singapore's past. These contributions should be viewed as examples of the way that Singaporeans have sought to explain parts of their past by adopting a global perspective while continuing to acknowledge local agency - an achievement that Jerry Bentley would have appreciated. This is precisely the type of study that is needed to create complementary narratives to balance the dominant political ones that focus on the achievements of the founding fathers of Singapore.

Leonard Y. Andaya

Department of History, University of Hawai i at Manoa

\section{Notes}

I An excellent overview of recent Singapore historiography can be found in Ho Chi Tim's "Past Trends and Future Possibilities for the Study of Singapore History", paper presented to the International Association of Asia Scholars, Singapore, 22-25 June 20IO.

2 Sonny Yap, Richard Lim, and Leong Weng Kam. Men in White: The Untold Story of Singapore's Ruling Political Party. Singapore: Straits Times Press, 2 ого.

3 Hong Lysa and Huang Jianli. The Scripting of a National History: Singapore and Its Past. Singapore: NUS Press, 2008.

4 Kwa Chong Guan, Derek Heng, and Tan Tai Yong. Singapore: A 700-Year History: From Early Emporium to World City. Singapore: National Archives of Singapore, 2009. 


\title{
1 Globalising the History of Singapore
}

\author{
Syed Muhd Khairudin Aljunied \& Derek Heng
}

World studies, which are more commonly referred to now as global studies, have become an increasingly important field of study, both in the social sciences and humanities since the early I970s. Beginning with discussions among economists and political scientists who sought to reconceptualise distributive and interactive dynamics between states and societies located in different parts of the world at the height of the Cold War, the boundaries of global studies have since widened as they gained the attention of geographers and sociologists in the final decades of the twentieth century. Their contribution to the institutionalisation of global studies in academia has mainly involved fresh approaches that enhance our understanding of the often unequal relationships between developed and developing countries. Keywords such as "interactive zones", "world systems" and "free markets" have become indispensable in any discussion about the world as a whole. The justification for the need to develop new vocabularies, promulgate new generalisations and invent new methodologies lay primarily in the assumption that humankind was facing "globality" and "globalisation", a condition and a process whereby traditional boundaries of space, knowledge and power are broken down, compressed, and intensified, by the advancement of information and transportation technology.

Where do scholars of the humanities fit into these developments? Historians in particular had a great deal to contribute to global studies, both as an academic discipline and as a subject of wider general interest after the Second World War. Historical monographs that sought to explain the evolution of human societies from earliest times up to the advent of modernity had long preceded the social sciences. Works such as William McNeill's Rise of the West (1963) and Marshall Hodgson's threevolume The Venture of Islam (I974) quickly come to mind. These two books represented a new wave of scholarship aimed at decentering the cyclical models of human development that had earlier been developed by Oswald Spengler and Arnold Toynbee. And yet the global perspectives that characterised these writings were quickly overshadowed by the pertinent concerns of the time. The dismantling of empires, the creation of new states and the outbreak of revolutions and insurgencies across the globe called for more formulaic, if not social scientific, approaches 
to understanding societies. Hence, McNeill's magnum opus was to give way to Immanuel Wallerstein's macroscopic study of modern capitalism; Hodgson's appeal for an inter-regional perspective to offset Eurocentrism in global studies did not gain the attention it deserved until the coming of the Saidian anti-Orientalist critique (Said I978). And it was only with the end of the Cold War that a change in academic praxis was ushered in, as discussions about the validity of past models and theories began to emerge in the social science circles and the work of global historians regained its much neglected importance. To understand the extensive effects and drastic changes wrought by modern-day globalisation and to give future generations an entirely new set of scholarly options, earlier patterns of global interactions became the subject of scholarly scrutiny approached in a more historically and empirically grounded way.

So what has emerged from this new wave of scholarship? Essentially three different modes of approaching, narrating and teaching global history. The first mode conceived global history as an extension of the study of Western civilisation. The fundamental theme such studies share is the rise of Europe as a world power. Appended to this master narrative are the roles and contributions of non-European states and polities in creating the conditions for Western hegemony in world affairs. The second mode aimed at decentering Europe's importance by giving more prominence to contemporaneous nations and civilisations. Here, Europe was portrayed as an equal competitor with other nations and civilisations in the struggle for primacy and survival within a global context. A recent variant of this mode tries to break down accepted ideas of nations, civilisations and the self to create more scope for 'cross-cultural' identifications and exchanges as well as overlapping boundaries. The third and perhaps most radical mode acknowledged the existence of nations and civilisations, while seeing these imagined spaces as mere nodes within intersecting political, economic and ideological systems that defined the course of humanity. Not ignoring the forces at play in local settings, this mode of representing global history sought to establish causal relationships between the structures and strictures of everyday life and patterns at more systemic levels, such as the flows of knowledge, capital and labour within a globalised economy (Dirlik 2005, 394).

This is, of course, not the place to discuss in detail the usefulness of each of these ways of approaching global history. However, one implicit feature that links all of these approaches is the prevalence of Eurocentrism and its attendant presuppositions. The notions of space, as a case in point, are unceasingly laden with assumptions that are inherent in western historiography. This can be seen in the consistent reliance on what Marshall Hodgon has termed a "Jim Crow world map", which is a projection of the "western image of the world". By placing Europe at the upper centre of the map and by assigning the land area the status of 
a "continent", Europe appears to be "far larger in scale than the Middle East, China and India" (Hodgson I994: 4-6). Europe then becomes a 'core entity' that had the upper hand throughout the march of modern history. The consequence of taking this perspective is to view and narrate global history, even in its most sophisticated form, around key themes such as the rise and decline of pre-modern empires, trans-regional socioeconomic interactions, the onset and impact of European colonialism from the late fifteenth century onwards, decolonisation and the challenge of globalisation, as well as postcoloniality (Lockard I995: 7-35). And, because of the continuing sway of such telos and paradigms, a sense of the universal applicability of concepts derived from the European experience to explain developments emerged across the globe (FernandezArmesto: 2006).

It is in the face of these trends and problems facing the field of global history that this volume was conceived. Southeast Asia's unique location at the interstices of the Indian Ocean, South China Sea and the Pacific Rim, the rapid flows of migrants and the movement of goods and natural resources in and out of the region necessitate, in our view, the employment of global history as a method for exploring and explaining continuities and transformations in the region. Indeed, over the past few decades, something fascinating has been taking place in Southeast Asian history. Once entrenched within the 'country' and 'nation-state' paradigms, the field has been challenged both by established specialists and new interlocutors, armed with fresh and often powerful global perspectives. Because of these new developments, Southeast Asian scholars have been forced to rethink, and at times to even abandon, their previous assumptions about the region's impact on the world and about how the world has shaped the region's tangled pasts. Scholars such as Wang Gungwu, Reynaldo Ileto, Benedict Anderson, Anthony Reid, James Scott, Victor Lieberman, Craig Lockard and Engseng Ho loom large in current attempts to look at Southeast Asian pasts through new global spectacles. The long-term implication is the widening of the scope of global history towards incorporating uncharted geographical spaces, enabling new modes of enquiry and rethinking long-held ideas of nationhood and regionalism.

Engseng Ho's The Graves of Tarim (2005), for example, deserves some elaboration here, as it has important methodical implications for the study of Southeast Asian pasts within a global historical perspective. Taking as its axis of analysis the tombs and shrines of the Hadrami Arabs, the book demonstrates the intertwined histories of people and places, of individuals and social collectives, texts and material remains located across the Arab World, South Asia and Southeast Asia. By grafting the fates and fortunes of a diasporic community - the Hadramis - within a global historical framework and devising new conceptual tools for discussing Southeast Asian experiences vis-à-vis the wider world, Engseng 
Ho has questioned the preponderance of the nation and its imagined borders within any unit of analysis. New ways of illustrating connectedness, convergences and parallels rather than variances and specificities - across oceans and continents - have sprung forth from this acute analysis of the trans-regional or internationalism that shaped the contours of the identity, politics, culture and ideas of a people in Southeast Asia. In that regard, Southeast Asian studies have a lot to offer to the global history discourse. By locating Southeast Asia in global history, which Engseng has eloquently done, we may at the same time rectify the undue relegation of the region to second-tier status in terms of academic importance - a phenomenon that is ubiquitous within academic circles in North America, China and even India.

It is in the light of such innovations in the wider Southeast Asian scholarly literature that the case for reinterpreting Singapore's past in global history can best be made. Although diminutive in size, the island's unique location at the southern end of the Straits of Malacca and midway between the Indian Ocean and South China Sea has made it a crucial site for contestations, negotiations and adaptations among a number of European and Asian powers, all of which were connected since pre-historic times through trade and migration (cf. Abu-Lughod I989 \& Chaudhuri I990). And, as the world became increasingly and intensively connected from the late fifteen century onwards with the advent of European colonialism, networks emanating into and out of Singapore were enlarged to include remote parts of North-east Asia, Australasia, the Mediterranean, the Pacific Rim, and West and North Africa. To be sure, these connections had implications for Singapore as had the island on the rest of the world. Put differently, the complex interplay of global and local developments in Singapore were in many instances moulded into new forms and relayed back to affect the larger external world. Charles Tilly's analogy of a flood to explain the outbreak of revolutions is instructive in this regard (Tilly I995). Several historical factors contribute to the occurrence of floods and, although these factors are often unrelated or, in their own terms, non-threatening, their confluence within a particular place at a particular time may result in the outbreak of major floods, or within the scope of Tilly's research, revolutions. The arena in which a variety of factors converge to provoke a flood could be likened to that of Singapore. While being shaped by global factors and developments from the tenth to the twenty-first centuries, Singapore's unique location has made the island a strategic launch-pad for individuals, organisations, polities and state machineries to influence, or at the very least, to predict major occurrences in the world.

In articulating a history of Singapore from a global perspective, it is also important to recognise that there are essentially two audiences that such an endeavour could address: the wider academic world and a domestic 
audience in Singapore and in Southeast Asia. With regards to the former, there are several reasons why such historical enquiries are important. Approaching Singapore from a global perspective would contribute to current developments in historical research, especially in the areas of identity formation and mobility across borders. Studies on the nature of the society, economy and politics in Singapore from a global perspective would open up new vistas for improving our understanding of other areas such as economic networks and business history, diasporic studies, as well as imperial, colonial and post-colonial regime change. Such contributions would no doubt be significant in the larger scheme of things.

The most important contribution has taken place in the field of citystate studies. In his recent seminal two-volume work, Victor Lieberman aptly demonstrates how analytical models of social and state developments that are derived from Mainland Southeast Asian experiences may be applied to further our understanding of such developments in such diverse localities as northern Europe, the Caucasus, China and Japan, by including such global factors as climate and disease, as well as assumed human commonalities such as the development of cultural singularities (2003 \& 2009). While Lieberman's work centres on agrarian states with substantial populations, this volume is an attempt to serve as a counterpoint, by interrogating nodal centres without extensive geographical or social hinterlands. In this regard, there are a number of regions in the world that share similar geographical, demographic and economic similarities with Singapore, including the Gulf of Mexico, the Arabian Sea, and the north China Sea, to name but three. A study of Singapore in global history could potentially serve as a basis for comparison by other historians working on the ebb and flow of city states. More to the point, in a world that is no longer confined to a bi-polar super-power order, but increasingly dominated by multinational corporations and a plethora of new post-colonial states, each with varying strategic significance, a study of Singapore as a city-state that was able to maintain a pre-eminent position throughout modern history would be an important step on the path towards questioning the current accepted narratives of global history. The core or dominant-centre perspective that is evident in the works of Ross Dunn (1985), Immanuel Wallerstein (I974), and Laura Benton (I996) could be redeveloped or even substantially revised. As a city-state well plugged into global historical experience, Singapore defies the argument that there was once a dominant European force that determined the dynamics of interactions between the core and periphery, as well as within the periphery itself. Rather, what comes out of all of the papers in this volume is a reinterpretation of what is assumed to be a periphery. In many ways, Singapore had established itself as a crucial centre within multiple and expanding global systems. The significance of this book is thus much wider than its title may at first sight suggest. 
Above and beyond academic concerns, global history as a framework for understanding Singapore's history is edifying as it addresses a changing domestic audience. As one of the contributing authors of this volume has correctly observed, the nation-state and 'big man' approaches to history appear no longer to be acceptable to today's Singaporeans. There seems to be an increasing desire among young and old in the country, as in Southeast Asia at large, to incorporate the collective social memories of the people into the official narrative. Alternative stories that go beyond great achievements of the founding fathers of the nation-state in the early years of decolonisation are being sought. Such new conceptions of the past are particularly pressing and relevant for nation-states that are currently affected by the wave of consumerist globalisation, changing social demographics, and economies that are overwhelmingly kept alive by migrant labour. We are compelled to conclude that a global mode of enquiry is indispensible for understanding the local. In this regard, global history, for these states and societies, is not merely an attempt at providing alternative narratives, but, as William Robinson observes:

Without understanding the existence of societies prior to the emergence of the nation-state, nation-states cannot be understood as isolated social systems under the assumption of a transhistoric symmetry between nation-states and social structure that rules out by ontological assumption and methodological fiat the study of social structure that is truly supra- or transnational in character. (1998: 566 )

It is important to bear in mind that ultimately it is not so much the notion that the official and nation-centred narratives are irrelevant, but that there needs to be a recognition of multiple narratives that should be accorded equal importance and attention. Even though each of these narratives is distinct, they exist in tandem with one another in a given historical timeframe. It is therefore not just the notion that a more coherent picture may therefore be developed when these narratives, like horizontal templates, are compressed vertically, but that each of these templates need to be understood and studied in their own right to complement and even interrogate the national narrative. In other words, these narratives should be interwoven to create an interactive historiographical dynamic that is distinct from the nation or country-centred historiographical trends in Southeast Asia, which are often saturated with teleological narratives.

Indeed, the teleologies, which largely centre on notions of innovation and change as well as development and progress under the auspices of the colonial and, in the post-I965 era, the post-colonial nation-state, have been projected back into the nineteenth and early twentieth century, and to an extent into the earlier, pre-modern history of Singapore. In particular, 
the focus has been on Singapore's commercial success and development as a major entrepot in the region, first under British rule, and then as a city-state after 1965 , with the colonial period as the foundation and precursor for its post-colonial success. This success story has also been cast as a unique history vis-à-vis the experiences of the surrounding region. Such a narrative relies heavily on the core-periphery model developed by urban geographers and macro-economists working on such regional and global issues as trans-border labour movements, capital flows and macrolevel vertical economic integration models, including those put forward by Saskia Sassen (1988), Yeung Yue-Man and Lo Fu-Chen (1996), and Scott MacLeod T.G. MacGee (I996), which locate Singapore in a semiperipheral space or at best as a secondary centre.

This volume, which is entitled Singapore in Global History, is a departure from both the teleological narrative of the successful nation-state that has hitherto been propagated internally and the location of Singapore in the semi-peripheral space in the larger global discourse that has been generated externally. Initiated by two historians based at the National University of Singapore and Ohio State University in the USA, this book, the content of which was partly presented at the International Convention of Asian Scholars (ICAS) in South Korea in the summer of 2009, consists of twelve papers spread across a broad chronological period and range of topics, bringing together scholars working in the fields of political science, international relations, history, sociology, literature, art history and architecture to explore ways in which Singapore's history could be examined from a global perspective. The volume makes a collective attempt at arguing in a radically different fashion that Singapore should be conceived as both core and periphery and that the logic of Singapore's success based primarily on the roles of big men and strong states is far from adequate. By locating the island as a central space between the major termini of maritime Asia and the world, Singapore comes out strongly in this volume as a location where global processes find their nesting place and where the roots of transformative processes that eventually emanated to other faraway parts of a globalising world could be traced. By adopting these new lenses, it becomes clear that states and organisations, elites and subalterns, and texts and other communicative media, have all added to the making of Singapore and the making of the globe of which Singapore is a constitutive part.

In the paper entitled "Situating Temasik within the Larger Regional Context: Maritime Asia and Malay State Formation in the Pre-Modern Era", Derek Heng argues that instead of taking the traditional view of the genesis and formation of a polity in the coastal Malay region as a consequence of human agency, abetted by the ability of the political progenitors to attract trade and people to settle at the newly founded port-city, the framework of analysis should be shifted towards the role of regional 
and international forces. By re-examining the history of state formation in the Malay region and its accompanying political, social and economic developments in the Indian Ocean South China Sea, Gulf of Siam and Java Sea region, Heng advances the point that even though states and port polities were dependent on human capital to ensure their sustenance, it is ultimately the prevailing external forces and circumstances that determine the nature of these entities within the Malay region. In that regard, Temasik, the port polity that existed on Singapore Island during the fourteenth century and which was active for only a little over a hundred years, serves as a prime example of the way in which the vicissitudes of a Malay port city almost entirely depends on the circumstances generated by external forces.

Following the same line of argument, Joey Long's paper, entitled "Bringing the International and Transnational Back In: Singapore, Decolonisation, and the Cold War", demonstrates the ways in which the strategic policies of the British government and the United States of America (USA) have had a direct impact on the fortunes of political parties, social movements, right down to individual personalities, in Singapore in the immediate aftermath of World War Two and, more so, in the period following the Suez Crisis in 1956 . By supporting anti-communist regimes and non-leftist political parties in Southeast Asia, both Britain and the USA have determined the course of Singaporean history and the lives of prominent political individuals in ways that would only become visible to us when the archives in both countries are mined extensively and fresh questions about the roles of great powers are asked. As it stands, much of the historical writing on Singapore has made questions about global influences secondary to the celebration of the local.

Even so, it is equally important to recognise that the unfolding of events in Singapore has had regional and international ramifications. The task of situating Singapore within a global framework need not entail a conception of the island as merely a recipient of international forces and influences, but also as a source which made global events possible. Syed Muhd Khairudin Aljunied paper, entitled "The Global Effects of an Ethnic Riot: Singapore, I950-54", observes that while scholarship on riots and rebellions in British colonial territories in Southeast Asia has, to a large degree, been dominated by the study of the causes, development and eventual suppression of these violent forms of popular resistance as seen through the lenses of national histories. Very little attention has been paid to investigating the effects and consequences of mass violence in a given setting, particularly during the period of decolonisation. His paper fills the lacunae in the available historical literature by exploring the global effects of the Maria Hertogh riots in colonial Singapore. He shows how news agencies and politicians in England reacted to the events that unfolded in the aftermath of the riots and brings to light the diplomatic 
fissures and tensions that developed between British and Dutch officials, as well as their Australian, American and Muslim counterparts as a result of the riots. By extending Tony Ballantyne's conception of the British Empire as “a complex web consisting of 'horizontal' filaments that run among various colonies in addition to 'vertical' connections between the metropole and individual colonies", Syed Muhd Khairudin Aljunied demonstrates that both the horizontal filaments and the vertical connections of the British Empire proved to be vital in ensuring that there were swift reactions to the protests of the various parties who were involved in the riots. He also show that, paradoxically, in an age of decolonisation the communication links and political networks established by the British also functioned as avenues of resistance and critique for politicians in newly-independent countries, as well as anti-colonial activists and news agencies in Singapore and Britain itself.

One implication of Aljunied's study is that global history can serve as a vital link between imperial and nationalist historiographies in Southeast Asia, which have often been regarded in historiographical terms as being largely irreconcilable. Stephen Dobbs, in a chapter entitled "The Singapore River/Port in a Global Context" bridges imperial and nationalist historiographies by arguing that the raison d'être for the founding of modern Singapore in I8I9 and its development through the nineteenth century was the changing global trading milieu in which the port of this tiny island - specifically the modern mega-port along the Singapore River - was to play a major role. The port of Singapore ranked as one of the busiest in the world, linking the island to the rest of the globe via a web of international maritime trade routes. While the modern state of Singapore has diversified its economic base significantly since becoming independent in 1965 , the role of the port in the modern city state is still emblematic of Singapore's place in global history. He makes the observation that, from its modern origins, Singapore has been inextricably influenced by global trends and forces, particularly in the realms of trade and migration, while at the same time shaping them.

In the same vein, Loh Kah Seng's paper, entitled “The British Military Withdrawal from Singapore and the Anatomy of a Catalyst", attempts to address the rupture between imperial and nationalist histories by reassessing the accelerated British military withdrawal from Singapore, which has been cast as a defining event in most narratives of the 'ends of empire'. Britain's decision in I968 to bring to a close its 'East of Suez policy and run down its military presence in Singapore has often been held as evidence of the city-state's tangled place in imperial history, whereas in the nationalist narrative of newly independent Singapore's meteoric rise as an economic 'Asian Tiger' under the enlightened leadership of the PAP government in the I970s, the British pullout has been cast as a "blessing in disguise". By approaching the withdrawal as a catalyst that 
not only enhanced Singapore's road to full industrialisation but also the state's efforts to socially engineer the citizenry, Loh's paper makes the argument that the Peoples' Action Party's efforts to convert the military bases, develop the industries, house the citizens, discipline the labour force, and socialise the youth were a continuation of measures introduced by the late colonial government after the Second World War in order to transform former colonies into viable nation-states. Alongside the colonial legacy which the PAP government inherited was the substantial assistance rendered by the British to ensure a successful withdrawal. Indeed, the post-war decolonisation and the military pullout that accompanied it - two sides of the same historical process - can only be properly understood if they are located at the interstices of nationalist and imperial histories.

Loh's paper, however, also demonstrates that the impact and ramifications of the global on the local, and vice-versa, can also be seen in the way that the international has had an impact on the experiences of individuals who were not necessarily of historically significance. His use of data from oral interviews with individuals from the lower strata of Singapore society, as opposed to significant individuals who tried to shape events in the immediate post-war and post-independence periods of Singapore's history, is an important contribution to integrating social historical methodology with global history.

The impact of the global on the local, and vice-versa, which are examined by Loh can also be seen in an earlier period - up to the Second World War - in the construction of an imperial order in Southeast Asia by the colonial powers on the one hand and negotiating pre-existing structures in the region on the other, with Singapore as the nexus where this mitigation process occurs. Huei-Ying Kuo, in her paper entitled "Social Discourse and Economic Functions: The Singapore Chinese in Japan's Southward Expansion between I9I4 and I94I" argues that in the face of the decline of British imperial power and the rise of Japan in the South China Sea, the Chinese bourgeoisie in Singapore, as a leading business group in the region, adjusted their business strategies to accommodate changing political-economic structures. While the literature has emphasised how the leading Chinese bourgeoisie supported anti-Japanese boycotts to rescue their business interests, Kuo, basing her research on Japanese intelligence reports, British colonial archives, and newsletters of Chinese business associations, argues that the development of Chinese sub-ethnic, or dialect, cleavages in Singapore in the first half of the twentieth century reflected the diverging responses among the overseas Chinese to the gradual but evident shift in the balance of power in Asia.

The paper shows that as part of Japan's intention to compete with the British for the support of the Hokkiens, the most important Chinese business dialect group in Singapore, British Malaya and Indonesia at that 
time, Japan recruited Hokkien Chinese living in Taiwan, then a Japanese colony, to take charge of Japanese ad-hoc business organisations in preparation for eventual southward military expansion. This trans-regional collaboration, the use of ethnic proxies and courtship only came to a halt in I928, when Chinese anti-Japanese feelings surged after the Jinan Incident in Shandong, China. The Japanese then shifted their efforts to securing economic collaborators among the Cantonese in Singapore and British Malaya. In the process, Japanese intelligence organs began to construct racial taxonomies to differentiate each major South Chinese dialect group, and this knowledge eventually became important for the formulation of plans to incorporate Singapore and British Malaya into the Greater East Asian Co-prosperity Sphere.

Kuo's paper reveals the vital roles that the Chinese in Singapore played in the realm of international trade and commerce, and why such analyses are indispensible in advancing our understanding of the dynamics of the economic interactions in East Asia and beyond. Traditionally, scholarship on this social group has focused on the nature of their commercial networks, social organisations, business models and socio-economic capital. This group has also been framed as peripheral, albeit important, to the key bastion of the East Asian economy - China - with terms such as "greater China" and "overseas Chinese" describing their wide-ranging activities. Counter to this grain, Jason Lim's paper, entitled “The Dynamics of Trans-Regional Businesses and National Politics: The Impact of Events in China on Fujian-Singapore Tea Trading Networks, I920-I960" casts the Singapore Chinese tea merchants as managing to build up an important economic activity, encompassing the production, processing, packaging, shipping and trade of tea produced in Fujian, China, with Singapore as the apex of their commercial activities, in the face of the general decline of the trade in tea in China itself. Singapore's status as a commercial hub in East Asia and the congregation of Chinese merchants and coolies, or blue collar labourers, on the island, enabled the Chinese tea merchants to develop what may be regarded as a precursor of the metropolitan region concept of economic production and consumption that economists and geographers have recently coined and articulated in detail, as well as the commercial phenomenon of outsourcing that has come to characterise the way that businesses operate in today's globalised economy.

However, in case one is tempted to get carried away with the triumphant sentiments that both Kuo and Lim's papers conjure up in terms of the regional and global reach of Singapore's commercial and economic activities in the early twentieth century, Lim also demonstrates vividly the limits of the ability of Singapore's business community - and the island's society at large - to mitigate the economic policies of states in the region, and by extension the world. He deftly shows that the ability 
of the Chinese tea merchants to build up their tea production activities and trade ultimately rested on their ability to seek out and leverage the loopholes that the political state of affairs in China accorded. Changes in the state of politics, particularly in the South Chinese province of Fujian, ultimately determined the fortunes and success of the trans-regional business model. In that regard, Singapore, as a global city of trade, was ultimately subjected to the vagaries of global political and economic forces and the flow of ideas.

Undeniably, attempts to connect the ideas and discourses of individuals, institutions and interest groups to the global context represent a growing trend among Singaporean historians in recent years (Heng \& Aljunied 2009; Kwa, Heng \& Tan 2009). While the primary focus has been the policies that these various actors were responsible for and the international implications that their policies and actions had, very little scholarship has attempted to link their ideas and discourses with developments in the wider world. Moreover, the extent to which the backgrounds, personal experiences, memories and political posturing of selected individuals had in shaping their beliefs - and in turn public policies that had international implications - remained unexplored. Ang Cheng Guan's paper, entitled "The Global and Regional in Lee Kuan Yew's Strategic Thought: The Early Cold War Years" is possibly the first by a diplomatic historian to look closely at Lee's strategic thought and its evolution from I965 to I990, when he stepped down as the Prime Minister of Singapore. Ang argues that in his capacity as the nation's first and longest serving prime minister, Lee Kuan Yew had unparalleled influence over Singapore's foreign and security policies. And as one of the world's leading statesmen, he was known for his proclivity for realpolitik when deliberating the state of global and regional affairs. By critically examining the speeches and writings made by Lee over the course of the last five decades, Ang successfully reconstructs Lee's thoughts on the Indo-Malay world, the regional institutions of Southeast Asia, the Indochina War, and the roles of the major global powers at the height of the Cold War. Ang's analysis is acute and nuanced, i.e. he shows how events around the globe influenced Lee Kuan Yew's thinking about his own country.

While Ang's focus is on the ideas of one of Singapore's most influential politicians, who viewed its history through the lens of major events in the region and their implications, Leong Yew's paper, entitled "A Brief History of the Hub: Navigating between the 'Global' and 'Asian' in Singapore's Knowledge Economy Discourse" critically analyses the disjunctures between the Global and the Asian in Singapore's knowledge economy discourse, as manifested primarily in the policies and programmes of major institutions such as the National University of Singapore. Yew's narrative interrogates the attendant implications of the state's attempts to fashion itself as a broker of Asian knowledge in the global arena. He 
brings to the fore the new missions which Singapore's universities innovatively promoted and the attempts by knowledge brokers to couch all disciplines, regardless of their orientation, toward scientific universality with an 'Asian' tint. This movement towards producing Asian' forms of knowledge displays a great deal of tension and ambivalence vis-a-vis the realities of the globalised present. More often than not, the attempts by the state and its related institutions to couch all things as Asian, and hence less foreign, are riven by paradoxes and contradictions, with Singapore becoming increasingly dependent on global processes of knowledge capital accumulation.

The brokering of globalised knowledge with an Asian tint, however, is not confined solely to the current context; it was evident as early as the late nineteenth century, when Singapore was plugged into the global order established by the British Empire. The essays by Lai Chee Kien, Torsten Tschacher and Philip Holden examine imaginings of the 'global' in relation to developments at the local level through a number of publications and art works produced by various social groups in Singapore at different points in time. In so doing, they provide us with the roots to the current penchant for promoting a "globalised Asian" identity, be it cosmetically or in forms that reflect the self-identifications of the individuals, social groups or institutions involved.

In "Rambutans in the Picture: Han Wai Toon and the Articulation of Space by the Overseas Chinese in Singapore" Lai Chee Kien asserts that the new environments and identities of the diasporic Chinese may be understood through negotiations between the urban and rural, labour class and the literati, sub-tropical and tropical lands, ethnic and subethnic communities, in order to create a particular overseas, but specifically southern Chinese, space. He marshals evidence from botany as an important and recurrent motif in shaping the literary, artistic and scholastic works of the overseas Chinese in Singapore, as well as the implications of this motif for identity construction. The Han Rambutan Orchard created by Han Wai Toon, a Hainanese who immigrated to Singapore in I9I5, is but one example of this construction of overseas identity in life and in works of art.

Tschacher's “'Walls of Illusion': Information Generation in Colonial Singapore and the Reporting of the Mahdi-Rebellion in Sudan, I887I890" narrates the role of newspapers in Singapore as purveyors of the stories and developments in Egypt and Sudan which, interestingly, had an impact on public sensibilities about major events the world over. As he explains, the texture of news and views presented in the Tamil and Malay language newspapers not only depended largely on the various newspapers' links to the larger information order, but also on the rerepresentations of received news made by the Tamil and Malay newspaper editors themselves, for the consumption of their readerships in 
Singapore. Hence, while The Straits Times, which had direct access both to Reuter's telegrams as well as to occasional letters from correspondents in Cairo, tended to provide lucid yet unsensational coverage of the Mahdiyya revolt, the Tamil Singai Nesan attempted to redress the balance by tapping into other flows of information which would not have been as accessible to the English press. The same could be said in regard to the Malay Jawi, Arabic and Chinese newspapers, which drew on alternative repositories of information and opinion in order to promote their unique versions of these events that shook the Muslim World as they did Europe. More crucially, arguing in parallel to the explanations of Aljunied as discussed earlier on, Tschacher's paper highlights the dynamic exchanges that were taking place within the Singaporean public sphere and the connections with the wider world, thus rendering the island as one among many fertile sites through which global knowledge and information were relayed and broadcast.

Similarly, Holden's paper, entitled "The Littoral and the Literary: Making Moral Communities in the Straits Settlements and the Gold Coast in the late Nineteenth and Early Twentieth Century", examines the formation of identities and cultures and the ways in which these self-identifications were transmitted in writing during the late nineteenth and early twentieth century, when knowledge and information were becoming more accessible especially to the literate elites in British colonies. This essay is important in another way in that it examines not just the Straits Settlements, but also elite self-constitution during a similar period in another British colony geographically remote from Singapore, the Gold Coast. Although located at opposite ends of the globe, the commonalities between these two places have been generally overlooked by area specialists and nationalist historians and this has implications for framing questions about the nature of colonial society. Holden thus breaks new ground by placing the texts produced in these two contexts within a single analytical framework. In reading the selected poems, biographical essays, and serialised fiction published in newspapers or magazines contrapuntally and highlighting the social and ideological contradictions embedded in them, Holden historicises the emergence of para-colonial elite discourses about the "moral community" that sought to challenge or even supersede the claims by states themselves at that time. In that sense, he has reinterpreted Singapore's historical pasts as one that traversed the same trajectory as Ghana, despite the dominant perception that these two colonies have had relatively distinct pasts.

Viewed as a whole, this volume corresponds to the vision that one of the doyens of global history, Jerry Bentley, has eloquently outlined: 'the need to globalize history and to historicize globalisation' (2006: I8). By globalising and reassessing the history of Singapore to include texts, events, processes and networks that had previously been conceived as 
either 'localised' or 'national' in character, what this volume seeks to achieve is to widen our understanding of the exogenous forces that have impacted the island and the endogenous variables that have made the island a site by which the world was coloured, shaped and transformed. Concomitantly and often obliquely, by historicising globalisation as a phenomenon that affected the world long before the coming of the digital age and McDonaldisation, each of the contributors to this volume has provided us with new insights into the dynamics of interactions and connections between the Southeast Asian region and the rest of the globe.

It is clear that the globalisation of Singapore and Southeast Asia as a whole had entirely different textures in the colonial and pre-colonial periods than those we see today. But underlying these surface differences are stark commonalities that came in the form of the movement of peoples, goods, cultures and ideas, which speak to the importance of this volume in deepening our understanding of the past and the present for the future. 



\title{
2 Situating Temasik within the Larger Regional Context: Maritime Asia and Malay State Formation in the Pre-Modern Era'
}

\author{
Derek Heng
}

\section{Introduction}

Singapore's history as a port settlement has, until very recently, been considered to date from around i8Ig. The general consensus had been that no significant settlement existed prior to that date. Indeed, the late Raffles Professor of History at the University of Singapore - Wong Lin Ken - once commented that "no historian has yet adequately explained why Singapore failed to be a major trading centre before the nineteenth century" (Wong I98I: I5).

Since the I980s, however, significant archaeological research, coupled with a reassessment of the historical documents relating to the island's history before the nineteenth century, have led to the conclusion that Singapore did have a history prior to the modern era. This history of the port settlement, which was known as Temasik, dates back to the late thirteenth and fourteenth centuries, after which there was a gap of around four centuries before Singapore was once again rejuvenated as a port city (cf. Heng I999, 2002; Miksic 1985).

While the historical genesis of Singapore has been successfully extended back into the past by more than five centuries, another issue remains: why did Singapore's history as a pre-modern state only start in the late thirteenth to fourteenth centuries? Archaeological data suggest that there was no settlement prior to the late thirteenth century and that the port settlement declined in the fifteenth century and ceased to exist in the early sixteenth century (Kwa, Heng \& Tan 2009: 59 \& 6I). More recently, research on Portuguese and Spanish textual accounts of the Straits of Singapore indicate that all the important events from the sixteenth to eighteenth centuries took place in the sea around the island, instead of on the island itself (Kwa, Heng \& Tan 2009: 63-82; Borschberg 2009). Its founding in the late thirteenth century has therefore been considered by historians to be an anomaly, leaving one to ponder why no port settlement of consequence existed before the fourteenth century or after the early sixteenth century. Wong Lin Ken's comment above is highly relevant here. The general pattern seems to contradict the inherent 
predisposition to settlement formation, given the island's strategic location at the crossroads of the Bay of Bengal, Java Sea and the South China Sea regions. The conclusion must be that an advantageous geographical location was, ultimately, only one factor in the eventual formation of this Malay state. How then, should the seemingly anomalous occurrence of Temasik's existence be framed within the study of pre-modern Malay state formation?

Indeed, attempts justify Temasik's existence have so far often led to its raison d'être being presented as a successful international entrepot. Attempts to situate Temasik within the longer history of states in the Malay region have often led to descriptions of the polity as the successor of Srivijaya, the mantle of which was then passed on to the Malacca Sultanate in the fifteenth century (Wolters I970; Kwa 2004). The premise of this argument appears to reconcile the short-lived success and tenure of the polity, although the actual reasons for this short tenure have never been satisfactorily elucidated or explained.

This paper aims to situate Temasik within the Malay region by moving away from a narrative of a series of successive states that dominated the region's political history in varying degrees of regional influence over the course of time and recasting the heterarchical nature of the Malay region as an integral part of the larger context of Maritime Asia. In this process, the logic of Temasik's founding and existence may be elucidated as part of pre-modern Malay state formation in the 'longue durée'.

\section{The study of pre-modern Malay state formation}

The study of state formation in the Malay region has had a long tradition of scholarship. Beginning with W.P. Groeneveldt (1876) and G. Coedes (I964), and more recently O.W. Wolters (I999), A. Reid (I988), L. Andaya (2008) and P. Manguin (2002), various scholars have explored the causes, motivations, and characteristics of these pre-modern states. However, there have to date been few coherent narratives about the fluid nature of the political history of these polities and the place of their relatively short life spans. In addition, no substantive attempts have been made to approach the history of pre-modern Malay state formation as a series of cycles or key periods over the course of time. The issues faced in historicising Temasik's history are therefore characteristic of the study of the region as a whole.

In an attempt to centre this history within the realm of Southeast Asian studies, studies on state formation history conducted to date have focused primarily on the localised context, the centrality of the various aspects of the Malay state under investigation and they have been confined to the period of the polity's existence. While this has raised the 
centrality of these polities within the larger discourse of Southeast Asian studies, as may be seen, for example, in Anthony Reid's seminal work Southeast Asia in the Age of Commerce (I988), there has been a tendency to view the process of state formation, chronologically and geographically, within the confines of Southeast Asia as a region. Indeed, much may be gained from exploring Southeast Asian state formation history within a much larger context.

The result may be seen in the historiographical processes that have thus far been employed. The first relates to the use of historical data. So far, indigenous materials have been given pre-eminence as the core data set from which the historical narrative and framework for understanding state formation has been formulated, while other materials, including exogenous data, have been accorded a secondary role.

While the place accorded by scholars to indigenous textual materials may have been based on the notion of maintaining a central focal point within the region (Reid 2007), these materials, all of which are oral traditions and literary traditions that have emanated from the Malay courts, are not without their limitations. First and foremost are the agenda and objectives for the textualisation of the oral traditions and courtly literature. In canonising the history of the state, of which the composers of these traditions and literary output are clients of the various royal courts, these literary sources tend to personalise the process of state formation (Wolters I970: 5 \& 6). To that end, even critical issues that are regional or extra-regional and largely beyond the mitigating efforts of individuals, such as trade and international diplomacy, have been presented as personal.

Exogenous textual data from outside of the Malay region, on the other hand, including primarily Chinese, Arab and Indian texts, have been used in two key ways. Firstly, the principle of first mention is used to trace or identify the genesis of Malay states and polities. Secondly, correlated links affecting the nature and development of states and polities, such as trade, may be extracted and worked into a historical narrative (Wolters I986). These data may then be supplemented by other sources, including archaeological data, to provide complementary evidence of the essential types of activities and reasons for the assumptions of the historical narratives, including a tentative indication of the occurrence of different stages of social and political organization.

Consequently, for the study of Malay state formation history, there has been heavy reliance on the oral traditions of the pre-modern era encapsulated particularly in the written traditions of the Hikayats and Sejarahs, the observations of Europeans of earlier centuries, such as the Suma Oriental and the accounts of such early western travellers such as S.J. Pere de Premare (de Querbeuf I780), and western-centric ethnological accounts of the nineteenth century onwards by such eminent scholars 
as Gullick (1958) and Braddell (1980). The resulting historical narratives of pre-modern Malay state formation have thus been subjected to the interpretative lens of the social and institutional imperatives of contemporaneous societies, both of the historians who produced the secondary works and the producers of the historical data sources themselves.

This trend in the scholarship on pre-modern Malay state formation may be seen in the works of such researchers as Wolters (I970), K. Hall (200I), and more recently Manguin (2002). Although spanning more than three decades, the primary thrust of the framework for understanding the process of state formation, as proposed by these scholars, may be summarised as follows. Firstly, Malay state formation and development has been premised on the scarcity of manpower, as opposed to the relative scarcity of arable land. Consequently, the success of state formation has been determined by the ability to attract manpower, as opposed to territorial acquisition. Given the context of the Malay region as the confluence of interaction between the Indian Ocean, Java Sea and South China Sea regions, the ultimate mark of the ability to attract manpower has been based on the ability of a port polity to control trade and garner trade goods, thereby leading to the formation of a cosmopolitan population. Finally, the state or polity has attained its most developed form when it has established and maintained external linkages - manifested by such channels as tributary relations with the key states of Maritime Asia - that are superior to those of its competitors in the region, thus enabling the establishment of a regional hierarchical structure with the state at its apex.

The result has been that while the current state of scholarship has advanced our understanding of pre-modern Malay state formation, the approach towards the use of the historical sources has resulted in a significant emphasis on both the indigenous process as well as the importance of human agency. The critical factor on which the polity's formation and survival is dependent is the ability of human agency to exploit these external factors. This is in spite of the fact that almost all of these factors have been beyond the mitigating efforts of individuals or groups in the Malay region. Leonard Andaya, for instance, has argued that while the physical conditions, which are determined by geography, have remained constant for the Malay region for centuries, the states and societies that have come and gone over time have been the result of human agency adapting varying strategies to the consistent geographical factors (Andaya 2008: 3-4). Manguin's study on political leadership and state formation in the Malay world also argues that external trade and the influx of foreigners into a port settlement were crucial factors that have led them to flourish as states and have conferred political legitimacy on their respective rulers, relying almost exclusively on indigenous traditions (Manguin I99I: 47-52). Finally, Hermann Kulke's discussion on Srivijaya's political structure, by nature of the fact that it relies exclusively on 'Srivijayan' 
epigraphic data, depicts the formation of the Srivijayan regional political structure as a wholly indigenous process (I993).

It is apparent that the current approach adopted by scholars, while clearly important, by and large addresses questions relating to the micro, or polity level. The macro level, where interaction between states, polities, economic spheres and cultural flows within the given region may be observed, has so far not been sufficiently studied. Some of the few exceptions are Wolters' work in the late Gos and early 7os on the Western Indonesian economy and state in the first millennium AD, Kenneth Hall's works on trade and state formation from the i980s, and that of the author of this chapter (Wolters I967; Hall I985; Heng 2009). In the case of the current state of scholarship on Temasik, for which indigenous texts, archaeological data, foreign records and colonial-era studies are currently available, there is still a lack of enquiry into these macro-level processes and the place of Temasik in the larger scheme of things. Discussions centre primarily on the dialectic between the dendritic model formulated by Bronson, and Karl Polanyi's port city model of political economy (Miksic 2004). The wider application of the heterogenetic model, which has so far been confined to the study of settlement patterns based on the material remains recovered through scientific field work (including archaeology), has by and large not been embarked on (Miksic 2000).

Taken together, it is clear that there are several issues that need to be addressed. The approach adopted in the use of historical information may require a move away from Southeast Asia to one in which all sources of information are examined from the same starting point. Such an approach may enable the various pre-eminent factors that led to state formation at various junctures in time and place to emerge, as opposed to being prematurely determined by the geographical field of study. It would also allow for a more nuanced understanding of the extent and limitations of the various indigenous and exogenous contexts, and both micro and macro-level issues, as circumstances that mitigated the nature of state formation over the course of time. Malay state formation may then be understood as a developmental process that occurred as a part of much larger contexts, rather than as self-contained, localised events. As Indian Ocean historian Sanjay Subramaniam has pointed out, the history of Southeast Asia needs to be viewed as part of a larger trans-regional development, simply because occurrences at one locality often had traceable effects in another (Subramaniam I999). In this regard, the interwoven dynamics between developments in the Bay of Bengal, South China Sea and Southeast Asia regions and their effects on the state formation process in the Malay region may be traced, and an argument may be made that Malay state formation was determined to a large extent within these larger contexts. It is on the basis of these discursive parameters that the current discussion will now endeavour to locate the port polity of Temasik. 


\section{Locating Temasik in the chronology of Malay polities in the first and second millennia $A D$}

In order to explicate the correlation between the larger regional context and the founding of Temasik in the late thirteenth century, it is necessary to first establish a working chronology of the rise and fall of the polities of the Malay region. The founding and demise of Temasik has been cast as a link in the chain of a series of chronological succession of Malay port polities that came and went through the course of the first and second millennia AD. In this way it is possible to reframe the polity's existence within the context of the region's political formation history.

The earliest references to Malay polities appear in Chinese textual documents. Kantoli, whose rulers are mentioned in the Chinese texts and which was mentioned in the Ming period texts by its former name Srivijaya, was noted to have dispatched envoys to China in 404. At the same time, according to Chinese texts a polity named Holotan dispatched missions to China, in 434 and 452 (Wolters I967: 152). The only indigenous source of information comes in the form of an inscription, dated between the $5^{\text {th }}$ and $6^{\text {th }}$ centuries AD and recovered at Kedah, alluding to the existence of a settlement of some form, although no ruler is mentioned in the epigraphic text (Wales I940: 8-IO). This period appears to have been characterised by competition between a few polities, all of which do not appear to have possessed any significant comparative advantage.

Up until this point, the regional political picture appears to have been one of several polities enjoying autonomy. By the 680s, however, this began to change. In 682, Srivijaya launched a military campaign against Java (Coedes I930). This campaign appeared to have been part of a larger political manoeuvre by Srivijaya to exert control over its immediate region. In 684, Srivijaya erected an inscription as a political compact between itself and its neighbouring polities, realigning the regional geopolitical framework into a different configuration. The first of its kind in the Malay region, the inscription details the formation of a two-tier system of polities in the region, with Srivijaya at the apex of the hierarchy. This event was followed in 686 by a second sea and land expedition against Java. By 692, Melayu became a part of Srivijaya (van der Meulen I977: 90). Srivijaya's sphere of influence also appears to have extended into the Gulf of Siam, as is evidenced by a Srivijayan inscription at Ligor dated 775. Finally, the Arab account Ahbar Akbar as Sin wa'l Hind suggests that by 9I6, Srivijaya had managed to extend its control up to the northern tip of Sumatra as well as South Kedah on the Malay Peninsula, although details as to what this 'control' constituted are not mentioned (Tibbetts I979: 32-36). 
By the late tenth century, more detailed information on the characteristics of the Malay regional political structure becomes available. Arab accounts note the existence of a "king of Zabag", 'Zabag' being the collective Arab term denoting Sumatra and Java, but more likely indicative of the Malacca Straits region. They also note that the kings of Kedah and other islands in the South China Sea, all of whom ruled under the king of Zabag, were known as 'Maharajas'. Thirdly, the raw produce of the region was regarded as the products of the land of the king of Zabag. This information suggests that the geo-political structure in late tenth century was primarily a two-tier system, in which a measure of local autonomy was exercised by the Maharajas of the polities that had submitted to Srivijaya, while Srivijaya maintained its pre-eminence in the international economy.

However, by the latter half of the eleventh century, the political situation in the region had begun to change. In IO7I, a port polity located on the north coast of Borneo Island sent a mission to the Song court that year, while Jambi sent a mission to China in Io79 (Tu I996: 42). Srivijaya's exclusive ability as a Malay polity to send missions to China was slowly coming to an end.

By the early thirteenth century, the Malay region had become more fragmented. According to the Zhufanzhi (1225), Jambi had by this time become completely independent of Srivijaya, both economically and politically. Although the text notes that Srivijaya continued to exercise some measure of influence over a significant number of settlements in the region, most notably Pahang, Trengannu, Langkasuka, Kelantan, Kuala Berang, Jiloting, Karimata, Tambralingga, Grahi, Sunda, Kompei and Lambri (Chen \& Qian 2000: 47), by I230, Srivijaya's influence over the Gulf of Siam had declined. A I230 inscription, recovered at Tambralingga, records that Tambralingga had annexed Grahi, formerly a dependent of Srivijaya, and that it had declared itself independent (Wolters I958).

Of the states that continued to be Srivijaya's dependents, they were experiencing a significant measure of economic autonomy. According to the Yunlu manchao (ı206), Kompei, Pahang and Kuala Beranang, all port polities located on the north-eastern coastline of the Malay Peninsula, were by this time maintaining direct trade links with the Chinese port city of Quanzhou (So I998), a situation that may be contrasted with the economic pre-eminence maintained by Srivijaya up until the eleventh century.

The decline of Srivijayan influence in the Malay region and the trend towards political and economic autonomy continued throughout the thirteenth century. More importantly, the void left by Srivijaya's shrinking sphere of influence was not filled by any state in the region. Rather it appears to have been filled by other Southeast Asia powers, notably Java, 
and later in the fourteenth century, Sukhothai. In I275, Javanese forces sacked the capital of Srivijaya, after which the Malay region witnessed the mushrooming of a large number of minor port polities. Marco Polo, passing through the region in 1292 en route from China to the Middle East, noted that there were eight independent port polities in Sumatra, each with its own ruler and language (Griffith 1997). The Daoyi zhilue (c. 1349) records a little fewer than twenty ports in the Malay region by the mid-fourteenth century, a number of which were newly nascent, including Trengganu, Kelantan, Pahang, Brunei (possibly Sungei Limau Manis) and Deli (Su I98I). It is during this period that Temasik, a port polity located on Singapore Island, was established. This state of affairs in the Malay region continued until the early fifteenth century, when the region was once again politically aligned under the authority of the Malacca Sultanate.

The key point to note in this chronology is that the histories of the Malay region's polities and states are not the sum total of random or disparate developments at the micro level, but that they concurred with the repetitive cyclical pattern of regionalization and fragmentation. This narrative thus serves to highlight the point that the history of Temasik needs to be seen as part of a larger regional political development and as a stage within the longer chronology of state formation history in the region. In this regard, the founding and tenure of Temasik is not as anomalous as may at first glance appear, but rather a logical outcome of regional events over time.

\section{Temasik within the larger maritime Asian context}

The above narrative, however, takes the context and reasons for Temasik's founding beyond the coherence of a regional narrative. If, as Subramaniam proposes, every historical event is connected in one way or another, then it follows that the genesis of Temasik may be found not only in the Malay region, but also within the context of larger forces at play within Maritime Asia. This larger context can be seen in how foreign policy, trade networks and economic imperatives of larger regional entities affected the viability and survival strategies of Malay port polities, as is evident in the political structures that were developed over time.

The Maritime Asian context, both centred on the Bay of Bengal and the South China Sea, and to a lesser extent the Java Sea and the Gulf of Siam, produced parameters which in turn functioned as constraints that limited or expanded the options that Malay polities had for state formation. The differences in the experiences of the varying areas of the Malay region - orientated either towards the Bay of Bengal or the South China Sea - suggests that the state formation process and the stages that 
the Malay region's polities went through varied significantly, depending on the policies of the larger states in these regions, resulting in diverse macro-level experiences that in turn determined the coherence of a given geographical region, in this case the Malay region encompassing the Malacca Straits and the Gulf of Siam. In the case of Temasik, its establishment and trajectory as an autonomous port polity was determined primarily by developments in the South China Sea and Java Sea.

Up until the seventh century AD, the polities or states of the Malay region appear to have been in mutual competition with each other, as is seen in the separate missions dispatched to China. Scholars have so far assumed that such a pattern in the dispatch of missions suggests a state of competition for the official recognition of China. However, China prior to the seventh century was in a state of political disunity, with only the Liu Song (420-479) in South China for a brief period maintaining an active interest in maritime trade coming into the Gulf of Tonkin (Liu Song Shu 5:I5a \& I6b). China's relations with the region, particularly in the economic realm, does not appear to have reached a critical mass that would have spurred a more coherent or concerted diplomatic strategy on the part of the Malay polities in their relations with China. More importantly, the absence of any mention of identifiable Malay port polities in Chinese official documents dating back to before the Tang period suggests that at least in the mind of the Chinese state, the Malay region did not figure significantly, if at all, in the maritime region south of the Bay of Tonkin. As such, it may be more accurate to interpret the pattern of missions as a situation where there was no coherent strategy in charting or determining the region's relations across the South China Sea.

On the part of the Malay region, it would appear that this state of affairs did not engender any circumstances that permitted any one Malay polity to supersede the others in any way, whether political or economic, at least in the context of the South China Sea. This appears to have had a significant impact on the nature of states in the Malay region. The known polities in the region at this time did not appear to have extended beyond the immediate areas around the key port settlements. Each polity appears to have maintained a small sphere of influence in the area immediately surrounding the key settlement location of the polity, with no epigraphic or textual data suggesting that these port polities had spheres of influence well beyond their core urban centres.

By the seventh century AD, however, a regional structure appears to have begun to appear. At least two more autonomous polities, located on the south-eastern coast of Sumatra, were noted by the Chinese. The travel account of the Chinese monk Yi Xing indicates that by 67I, Melayu and Srivijaya were active (Wolters I983). By the 680s, Srivijaya's ruler appears to have developed a political compact that continued the recognition of the 
local autonomy and position of the local chieftains of the Malacca Straits region, while binding them in an oath of loyalty. This two-tier system of politics in the Malay region was based, according to Kulke, on a structure that accorded political autonomy to the localised chiefs, while maintaining overlordship over their external dealings (Kulke I993: I7I \& I72).

This new regional geo-political structure appears to have been made possible, to a significant extent, by the end of the diffused pattern of interaction between the Malay region's polities and China. Jambi's diplomatic mission to China in 644 represented the last of the disparate diplomatic efforts by Malay polities. After that, the interactive pattern gave way to exclusive diplomatic relations between China and the Malay region, maintained under the sole auspices of Srivijaya and China, which had been unified under the Tang Dynasty ${ }^{2}$.

Previous conclusions that the six Srivijayan missions to China between 670 and 742 were most likely an indication of Srivijaya competing for China's attention and official recognition as part of its overall strategy to be the dominant polity in the Malay region do not take into consideration that there was in fact no more competition in the diplomatic realm after $644^{3}$. Indeed, the absence of any textual record to suggest that the Tang court was encouraging, implicitly or otherwise, some form of competition amongst the Southeast Asian or Malay states in attaining recognition by China as the representative state of the region, can only imply that China did not have a coherent foreign policy in its dealings with the Malay region. The Tang court only made three known attempts at engaging foreigners arriving via the South China Sea: a mission in 683 that called at Srivijaya, an edict in 695 stating that provisions were to be made for foreign traders at the port of Guangzhou before they left China, and the appointment of Superintendent of Mercantile Shipping at Guangzhou in 7I4 to manage maritime trade (Kuwabara 1928: 8). These efforts pale in comparison to China's efforts at engaging foreign trade and states during the Song period (960-I278), during which time there was a direct correlation between the maritime trade policies and foreign policy objectives of the Song court (Heng 2009: 72-IIO).

As such, the state of affairs in China did not directly result in the Malay region's geo-political reconfiguration. Instead, Tang recognition of Srivijaya by 683 allowed it to complete the construction of the Malay regional structure that it had begun to construct half a century ago. Srivijaya's exclusive prerogative in driving the Malay region's external interactions across the South China Sea and the two-tier geo-political structure in the Malacca Straits established by the late seventh century, appear to have been based on two key premises. The first pertained to China, the South China Sea and the Gulf of Siam. Given that Chinese citizens were not permitted to venture abroad for the purpose of trade, China was the recipient of whatever trade was brought to its shores by 
foreigners. China's economic relations with Maritime Asia were therefore perpetuated by its foreign partners, and its vision of these foreign regions was based on the information and images projected by the states that interacted with the Tang court. China's view of the Malay region would have been one that was largely based on Srivijaya's narrative of the state of affairs in the region. Chinese imperial perception of the Malay region most likely remained largely unchanged through the course of the eighth to early tenth centuries, even as the market demand for foreign products attainable from or via Southeast Asia grew, until 904, when political authority of Guangzhou was passed from the Tang to the Kingdom of Min (Clark 2002: 64-70). This stability allowed Srivijaya to concentrate its efforts on state formation in the Malay region.

The second premise pertained to the immediate neighbouring areas in Southeast Asia. The feasibility of developing the geo-political configuration of a two-tier system in the Malay region was actively attained through the military incursions initiated by Srivijaya into Java, the closest regional neighbour to the Malay region. Occurring in the late seventh century during the peak of the geo-political formation process in the Malay region, these incursions were probably due to the perceived need to create a competition-free zone at the periphery of Srivijaya's new sphere of influence as a concurrent requisite of the new framework. The epigraphic inscription commemorating the military campaigns launched in 682 and 686 , while not noting that territorial expansion was part of the objective, may have been over control of the Sunda Straits. The culmination of its military success against Java, the Tang court's recognition, and the political compact with a number of polities in the Malay region, enabled Srivijaya to absorb Jambi, its most serious competitor in the Malay region, into its political fold by 692 .

The availability of a regional competition-free vacuum that worked in the Malay region's favour was not entirely of Srivijaya's making. The ramifications of a unified China under the Tang, which translated both into a revitalized market as well as Chinese territorial ambitions along the southern borders, led to a reconfiguration of Mainland Southeast Asia's politics. The magnetism of the China market attracted the sustained attention of a number of newly emergent mainland Southeast Asian states, including Linyi (South Vietnam) and the Khmers in Cambodia, as is evidenced by the dispatch of several missions to China through the course of the late seventh and eighth centuries, causing a northward shift in the locus of prosperity in Mainland Southeast Asia (Coedes I964: 8I-IO9). The concurrent decline of Funan from the fifth century AD resulted in the Gulf area lacking any significant political force during this time. This enabled Srivijaya to extend its sphere of influence, in the second stage of its regional state formation process, into the southern half of the Gulf region, successfully bringing Ligor under its political authority by 775 . 
Srivijaya's regional hegemony being premised on the state of affairs in the South China Sea area that predisposed its success may be due, in contrast, to Srivijaya's limited fortunes in the north Malacca Straits. This area was clearly an important gateway and landfall for shipping and trade traversing the Bay of Bengal. Interaction between the Indian sub-continent and the Malay region began as early as the late first millennium BC. Indian activities across the Bay, which were vibrant as early as the third century $\mathrm{AD}$, were proactive, in contrast to China's passivity. One of the earliest records of Indian activity in the region is a stone inscription dated to the $5^{\text {th }}$ century, which contains a prayer by a sea captain for a successful voyage across the bay to Kedah. In addition, Kedah, known as Kadaram in Indian texts, was also noted in Pallava $\left(4^{\text {th }}-9^{\text {th }} \mathrm{c}\right.$. AD) texts as the first landfall across the bay. The implications for Malay state formation were consequently not the same as those resulting from the situation in the South China Sea.

Trade was the most important reason for communications across the Bay of Bengal. Yet, despite economic, cultural and social interaction, there does not appear to have been any significant state formation activity in the northern Malacca Straits area until the late first millennium AD. While such places as Lobu Tua and Kedah were well-known to traders from India and the Middle East (Tibbetts I979: II8-I34 \& I40-I49), a number of distinctive characteristics may be noted of these ports. Firstly, there was an absence of some form of political focal point at these settlements. The various locations of the pre-tenth century temple sites clustered around the Sungai Mas estuary in South Kedah do not reflect the presence of any spatial focal point. This characteristic can also be seen at Lobu Tua (Guillot I998). Secondly, the epigraphic relics erected in the area were commissioned by Tamil traders and not by the indigenous people. Thirdly, no missions were forthcoming from the ports of this region to China until the end of the thirteenth century.

Together, these characteristics suggest that the basis for the initial state formation process in the northern Malacca Straits area must have differed significantly from that of the southern Malacca Straits area. One major contextual factor may be noted. While itinerant traders would have formed a substantial portion of these traders, by the fifth century $\mathrm{AD}$, the South Indian merchant guilds, emanating from the structures of economy in South India under the Cholas and Pallavas, were beginning to make significant headway in the Bay area. This development coincided with the affiliation of the maritime merchant guilds on the east coast of the Indian Sub-Continent with those that controlled the inland trade in the sub-continent, linking the economies of these regions together through coherent, institutionalised socio-commercial networks (Hall I978 \& 2010). 
The four South Indian inscriptions recovered so far from this area at Kedah (c. $5^{\text {th }}$ century); at Takuapa (c. 820s-840s); at Lobu Tua (Io88); and at Neusu Aceh (c. twelfth century) - suggest that up until the twelfth century, Tamil merchants and Tamil guilds played a brokering role in the port settlements' rituals, trade and even taxes (Wisseman-Christie I998). The Takuapa inscription records the building of a tank and its subsequent placement under the protection of the members of the Manikkirmam, a Tamil guild (Sastri I949). The Lobu Tua inscription, commissioned by a Tamil guild, records the issue of tithes to be paid by arriving Tamil vessels to support the upkeep of a local Hindu temple, presumably built by the Tamil merchants in exchange for commercial access to the area (Wisseman-Christie I998: 257 \& 258). The Neusu Aceh inscription makes references to a Tamil guild, and possibly the issue of regulations concerning trading losses (Wisseman-Christie I998: 259). The language of the inscriptions suggests that the Tamil guilds had significant administrative prerogatives at these places.

The presence of these inscriptions is in stark contrast to the absence of inscriptions made by the settlements' indigenous populations. This state of affairs differs from that of the south Malacca Straits area, Gulf of Siam and Java, where the inscriptions were primarily erected by the indigenous people. It is likely, therefore, that the political structure of the north Malacca Straits settlements included the Tamil guilds in an integral manner.

The fact that the instructive contents of the Tamil inscriptions had not changed much from the fifth to the twelfth centuries AD suggests that nature of state formation and social formation in this part of the Malay region did not change much over the course of these eight centuries. Nonetheless, a brief interlude appears to have occurred during the ninth and tenth centuries. The overtures towards India initiated by Srivijaya in the mid-ninth century, involving the dispatch of a mission to the Pallava court and the building of Buddhist monasteries in Pallava territory in India in 860 (Sen 2003: 220), were unique efforts on the part of Srivijaya in its interactions with the states across the Bay of Bengal. These overtures also coincided with the peak of Srivijaya's influence over this part of the Malay region in the late ninth and early tenth centuries. Early tenth century Arab accounts note that Srivijaya had managed to exercise some form of control up to the northern tip of Sumatra as well as South Kedah on the Malay Peninsula. This control however, was short-lived. A 995 Arab text provides important data concerning this geo-political change. While the Malay region, including the Gulf of Siam and the north Malacca Straits, was known collectively as one geo-political entity and under the ruler of Srivijaya, Kedah was noted to have had its own ruler. Kedah's produce, however, was considered part of the trade commodities made available by Srivijaya to foreign traders. Hence, while Srivijaya's political 
influence over the north Malacca Straits area appears to have receded, it continued to maintain a pre-eminent role in the international economy of the area.

This rapid decline of Srivijaya's influence over the north Malacca Straits area may be seen in the nature of the overtures that it initiated with the Cholas between I005 and IоI6, during which time Srivijaya built at least one vihara at the Tamil port city of Nagapattinam, and made several gifts to various temple deities. While these overtures were attributed to the Srivijayan ruler, the Srivijayan agent who carried out these overtures was in fact the ruler of Kedah (Chandra 1957: I5).

The extent to which Srivijaya was able to project its influence into the north Malacca Straits area was therefore affected by Indian interests in the Bay of Bengal. Spencer and Hall have argued, for example, that the Chola court's favourable acceptance of these overtures made by Srivijaya at Nagapattinam was not an act of rescinding its sphere of influence across the Bay of Bengal, but purely for the purpose of encouraging the arrival of traders from across the Bay (Hall I978; Spencer 1976). In this regard, the political context of the north Malacca Straits could easily be subverted by the Indians whenever they were capable and willing to do so. This is clearly exhibited by the Chola raids in the Malay region between I025 and I028. The contents of the inscriptions in India commemorating the event suggest that the major gateways of the Malay region into the Bay of Bengal were most severely affected by the campaign. The treasures of Kedah were plundered, while the Srivijayan ruler was taken into exile in India (Sen 2003: 22I). Another Chola raid, conducted across the Bay in the Io6os, resulted in the retention of Kedah under Chola influence. A stone inscription dated to Io68, commissioned by the Chola ruler Kulothunka I and erected at Kedah, commemorates Chola overlordship over that port city. The extension of regional hegemony under the auspices of Srivijaya over the north Malacca Straits during the late ninth and early tenth centuries appears to have occurred at a time when there was a political transition in South India, which led to a temporary suspension of South Indian efforts in the north Malacca Straits. At other times before and after that transitional phase, the Malay regional political structure could not be extended into this northern area.

South Indian economic influence continued to be projected well into the twelfth century under the institutional auspices of the Tamil guilds. However, by the thirteenth century, this influence had begun to wane. The Tamil-language inscription recovered in the Padang Lawas area, dated to the thirteenth century, makes no mention of any Tamil guilds or traders, but instead refers to the founding of a settlement and the making of meritorious gifts (Christie I998: $262 \& 263$ ). This change in context, from direct references to links across the Bay of Bengal to references of indigenising South Indian settlement activities in the inland 
reaches of Sumatra, reflects the decline of Chola political power in South India, the remnants of which were eventually absorbed by Vijayanagar in the fourteenth century. Accordingly, institutionalised Tamil influence receded from the Malay region. Coincidentally, it is during this time that Lambri, Semudra and South Kedah emerged as autonomous polities (Heng 2009: I05). However, unlike the ninth century, when a similar political transition in India led to the extension of Srivijaya's regional influence in this area, the changed context in the South China Sea forestalled the recurrence of such state formation.

The extent to which the form of the polity and the nature and extent of the regional political structure of the Malay region depended on the dialectic pull of South India across the Bay of Bengal on the one hand, and China across the South China Sea on the other, is evident up until the late twelfth century. By the early thirteenth century, however, the convergence of differing developments across the Bay of Bengal and the South China Sea led the Malay region into another phase of state and regional political formation.

Up until the late tenth century, although the Song court (960-I278), which had unified China since the 970s, encouraged maritime trade between the states of Maritime Asia and China, the premise of this interaction remained largely the same as during the Tang period. Consequently, the Malay region's operative environment across the South China Sea remained largely unchanged. The major change during this period came, instead, from both Mainland and Island Southeast Asia. On the mainland, the rise of the Khmers, as well as Champa (coastal present-day Vietnam), posed significant competition to the Malay region in the purveying of trade products from Southeast Asia to China. Increased intensity of interaction also occurred with Java, with the Javanese kingdoms having substantial maritime interests both across the Java Sea into such places as South Sulawesi, and with China and South India, and had commenced competing for space in the west Java Sea area. A spectacular mission dispatched to China in 99I was well-received by the Song court, and a twelve-year Javanese naval blockade against Srivijaya was imposed in 990 (Heng 2009: 8I).4

While Srivijaya managed to maintain an upper hand in the Malay region's interactions with China, significant changes in the Chinese context were already under way. From 982, the Song court progressively liberalized the Chinese domestic trade in foreign products into private hands. Chinese private commercial shipping was permitted to trade abroad from 989 and by ro9० private shipping was fully liberalized along the Chinese coastline (Heng 2009: 38-54). These changes saw Chinese maritime shipping, import trade and the domestic trade in foreign products liberalized to its fullest extent up until that time in Chinese history, resulting in the integration of the economic production of the Chinese 
coastal hinterland, foreign markets reachable by sea, and Chinese market demand for foreign products, as well as the integration of commercial and distributive networks within China with Chinese shipping networks and maritime trade. One of the critical effects was that Chinese traders became increasingly involved in exporting Chinese products into Southeast Asia and procuring Southeast Asian products directly, and Indian Ocean products indirectly, from the region itself. Southeast Asian ports could now cater to the Chinese market by catering directly to the Chinese traders who were arriving in the region annual to trade (Heng 2009: I05-IIO). The increasingly pervasive presence of the Chinese in Southeast Asia, and the explosion of Chinese knowledge of maritime Southeast Asia, dramatically altered the operative environment for polities in the Malay region.

By the Io7os, the pattern of exclusivity in Srivijaya's intercourse with China was disrupted. Boni, a port polity located on the north coast of Borneo, and Jambi, dispatched missions to China in I07I and Io79 respectively. The disruption to the established pattern was emanating not just from within the Malay region, but from China as well. In II30, following the II 27 flight of the Song court south to Hangzhou, the court identified four states in Southeast and South Asia as key states in their respective regions, and accorded lands in China to these states so that a permanent representation, supported by regular visits of diplomatic representatives, could be established (Heng 2009: IOI-IO2) $)^{5}$. At the same time, tribute missions began to be regarded by China as acts of obeisance by lesser polities in response to the pre-eminence and attractiveness of the Song emperor's imperial virtue ${ }^{6}$. Sino-Malay diplomatic relations during this period deteriorated, marked by only three missions dispatched to China. The II37 mission was accorded honour belatedly, the II5 6 mission was told by the emperor that missions were not meant to be occasions to promote economic interests but as occasions for displaying admiration for the Song court's imperial virtue, and the II7 8 mission was never received by the Song court, but redirected while it was en route from Guangzhou to the court to Quanzhou and handled by the port authorities as ordinary trade?. These mission outcomes reflect a progressive decline in Srivijaya's status in the Song court's eyes. One of the key factors on which Malay regional hegemony was based was becoming inapplicable. The regional structure, centred on and perpetuated by Srivijaya, was no longer tenable.

By the beginning of the thirteenth century, Pahang and Kuala Beranang, polities in the Gulf of Siam that had previously subsumed under Sirvijaya's economic umbrella, had already established direct economic relations with the Chinese port city of Quanzhou (So I998: 205308). The fact that only the polities in the Gulf of Siam were beginning to exercise economic autonomy suggests that the core of the Malay regional 
structure in the Malacca Straits was still intact. The establishment of economic links with Quanzhou, rather than Guangzhou, so far the primary Chinese port of call that Srivijaya operated at, suggests that these polities were still exercising some diffidence towards Srivijaya within the South China Sea context.

The situation deteriorated quickly thereafter. By I225, Jambi seceded from the Srivijayan regional structure after an armed conflict with its former overlord (Chen \& Qian 2000: 46 \& 47). In I230, Ligor ceded from Srivijaya's sphere of influence, taking Grahi, a Srivijayan dependency, into its political orbit in the process (Coedes I964: I84). The former geopolitical structure of the Malay region - a two-tier framework bound by a political compact premised on the exclusivity of external interactions by the polity at the apex - which had served as the basis of Malay state and regional formation since the late seventh century, was no longer relevant nor sustainable by the early thirteenth century.

The growth of Chinese economic activities in the region, coupled with the changes in the foreign policy imperatives of the southern Song court, coincided with the decline of South Indian influence across the Bay of Bengal, mitigating whatever the transition in political power in South India may have had on the trajectory of Malay state formation. Previously in the ninth and early tenth centuries, the transition of power in South India, coupled with the unchanged situation in the South China Sea area, had opened a window of opportunity for Srivijaya to proactively extend its political authority into the north Malacca Straits. In the thirteenth century, however, the changed environment in the South China Sea, and the ascendency of Java and Thailand in maritime Southeast Asia, prevented any expansion of the Malay regional structure from taking place. Instead, these larger developments paved the way for the era of disparate autonomous port polities to recommence after a gap of five centuries.

China, although unified under Mongol rule by I279, did not show the same level of interest in re-establishing relations with the polities of Island Southeast Asia, with perhaps the exception of Java. Although the maritime route was used to carry official communications with the South Asian states, the Central Asian land route was reopened, becoming the primary conduit that connected the different khanates that spanned Continental Asia. The Malay region was therefore left, in the second half of the fourteenth century, to the pull of regional polemic forces of an ascendant Java to the south and Sukothai (Thailand) to the north (Miksic 2005).

Perhaps the most fundamental change in the thirteenth century, however, appears to have been the way in which the nature of state structure in the Malay region was transformed. Previously, the social polity in the southern Malacca Straits appears to have revolved around a charismatic individual. This framework had been evident in the structure fostered 
by Srivijaya since the political compact was initiated in the late seventh century. By contrast, the social polity in the northern Malacca Straits appears to have revolved around a collective. The investiture of a ruler, however, does not appear to have been part of the state formation process in the north until the thirteenth century, as evidenced by the local oral and subsequent written traditions of the area, such as the Hikayat RajaRaja Pasai and the Hikayat Aceh (McKinnon I984: 362-363; Hill I960).

These developments were given further impetus by the broader Southeast Asian context. The rise of Singhasari in East Java in the thirteenth century, with its regional political ambitions, may have been a major hindrance to the continuation of a Malay regional order. In I275, the capital of Srivijaya was sacked by Singhasari forces, thus bringing the centuries-old Malay regional structure to an end (Heng 2009: I06). This state of affairs was further exacerbated by Javanese expansionism in the Malay region in the fourteenth century. Between I329 and I357, Javanese influence under Hyam Wuruk extended over the southern half of the Malacca Straits region, to include Pasai, Palembang, Jambi, and Pahang (Robson I995). Consequently, the Malay region witnessed the mushrooming of a substantial number of port settlements in the late thirteenth and fourteenth centuries, each being fairly limited in scale and geographical extent. This is reported in Marco Polo's account of the region, in which he notes that there were eight polities in the Malacca Straits, all of which had their own ruler and language (Griffith I997: 215-222). The Chinese text Daoyi zhilue (c. I349) records at least eighteen port settlements in the Malay region, all of which had their own rulers or chieftains and maintained fairly autonomous economies (Su I98I).

A number of autonomous port polities were founded during this time, most notably Temasik, Kelantan and Trengganu (Su I98I: 99, I02, I96 \& 213), although a number of unrecorded port polities, including those located at such places as Sungei Limau Manis, present-day Brunei (Jabatan Muzium-Muzium Brunei 2004), also appear to have emerged. All the polities of the Malay region maintained sporadic, independent relations with China through the late thirteenth and fourteenth centuries, with missions dispatched to the Yuan court only when these were demanded of them by that court. This situation eventually led, by the third decade of the fourteenth century, to the various polities of the Malay region ceasing to make any attempts to reach out to the first tier states of Maritime Asia (Heng 2009: 64 \& 65).

It is in such a context that Temasik was founded in the late thirteenth century. It lasted as an autonomous polity until the beginning of the fifteenth century, when, according to the Sejarah Melayu, it was overrun by Majapahit forces and the last ruler of Temasik had to abandon the port city and flee northwards to Muar, modern-day Johor (Brown I970: 50). Temasik's short tenure as an autonomous port polity was also 
characterised by the localised extent of its influence within the Straits of Singapore area, only extending into the Riau Islands and possibly South Johor during its peak. It was one of a number of autonomous port polities that existed in the Malay region during that time, a state of affairs that did not exist prior to this period and after which all of them invariably lost their political autonomy to more powerful neighbours (during the fifteenth century). After the fourteenth century, it became a minor settlement whose population and economy was eventually hollowed out by Malacca, and which politically became the fief of the Admiral of the Malaccan court (Cortesao I944: 264).

This extended narrative demonstrates that Temasik's founding was an event borne out of the regional contexts that existed in Maritime Asia during the late thirteenth and fourteenth centuries. More importantly, it was also the culmination of developments that occurred over the course of almost a millennium and made possible by the unique set of circumstances in the Bay of Bengal and the South China Sea, without which the polity's founding would most likely not have been possible. In a sense, although the strategic significance of Singapore Island's geographical location was ultimately a minor factor leading to state formation on the island, the strategic importance of events and policies projected from both the Bay of Bengal as well as the South China Sea had a fundamental impact on state formation in the Malay region.

\section{Maritime Asia as the key determinant of the characteristics of Temasik}

While the above narrative argues for the case at the macro level, the impact of the parameters set by the larger maritime Asian context filtered down to the micro level, or the polity-level, as well. The characteristics of the Malay polities of the first and second millennia AD were, to a large extent, constrained by the parameters that the Maritime Asian context of this period have set in place, thus affecting the same characteristics that the polities ultimately developed. How did this process manifest itself in the case of Temasik?

The Sejarah Melayu, the only historical text containing a narrative of the founding of Temasik, narrates that Sri Tri Buana, originally a ruler of Palembang, had arrived on Singapore Island after a temporary sojourn at Bentan. He brought a significant entourage of political elite members and commoners of Palembang with him, including the Orang Laut of Bentan and their leader. The port polity eventually became great when the ruler managed to attract both international trade and foreign traders to the port city (Brown I970: 28-55). 
Three key points may be elucidated from this indigenous narrative. Firstly, Temasik's founding and tenure has been portrayed as a consequence of political rule from Sumatra. The continuity of this political succession is apparent when one considers that Temasik's tenure is followed by that of Malacca by the last ruler of Temasik. Secondly, human agency and the ability to attract followers and talented individuals and to command the waterways led to the success of the port polity. Thirdly, the port polity was proactive in attracting international trade and traders to its port.

Other sources of information on Temasik, however, portray a different picture. Firstly, Temasik's tenure was short, or more to the point, abrupt. Geographical texts dated to around the beginning of the fourteenth century, including Marco Polo's account, Ibn Said's account from the late thirteenth century and the Dade nanhaizhi (c. 1307) do not mention any settlement at the southern tip of the Malay Peninsula. It is only in the mid-fourteenth century that any mention of Temasik is made. No other textual record of Temasik is noted after the fourteenth century, with all references made being to the island and Keppel Straits, rather than to a port polity. The unique context of the late thirteenth to fourteenth centuries, when China, under Mongol rule, was more interested in keeping in contact with the other khanates across Central Asia, and when interaction with the kingdoms of the Indian Sub-Continent were more important than relations with Southeast Asia, only lasted until the advent of Ming rule in China in $\mathrm{I368}$. The absence of diplomatic overtures on Temasik's part was therefore reflective of the conditions in China, although the ability of Temasik to engage China diplomatically remains questionable.

Temasik's abrupt and short-lived existence is borne out in the archaeological record. Most archaeological remains date to the fourteenth century, with no artefact datable to before the late thirteenth century having so far been found. A small quantity of finds date to the post-fourteenth century period and the sites are sterile again between the sixteenth to early nineteenth centuries (Miksic I985: 52-54). The archaeological remains, in the absence of a much longer archaeological record on Singapore Island, effectively stand alone from a chronological point of view.

Secondly, the notion that there was a significant volume of international trade or the presence of foreigners in Singapore during the Temasik period is in fact not well-supported by the historical data from such exogenous sources of information as the Chinese texts of the period as well as the archaeological data accrued from the island. The Daopi zhilue, for example, records that Temasik only made hornbill casques, lakawood, tin and cotton textiles available for export (Su 1981: 196). The nature of Temasik's external economy, in which the port made select offerings available, as opposed to the notion of an international emporium that characterised Srivijaya some centuries ago, is in line with the economic 
context of Maritime Asia during this period, where foreign traders would travel around the Malay region to obtain products from specific ports known for the key products that they specialised in (Heng 200I \& 2008). The product range, and the extent to which Temasik was an emporium, was therefore constrained by the nature of foreign trade operating in the Malay region during that time, which in turn was the result of policies promulgated by the larger states of Maritime Asia.

Similarly, the archaeological finds do not portray the existence of a rich emporium during the Temasik period. The ceramic finds predominantly come from wares produced in the kilns of Guangdong and Fujian, in particular those located near the ports of Guangzhou and Quanzhou. A very small proportion of shards come from wares produced in the Jiangxi, Zhejiang and Jiangsu kilns. This suggests that the economic interaction between Temasik and the Chinese market was confined largely to the immediate hinterlands of Guangzhou and Quanzhou (Heng 2004: 78). In addition, the coinage recovered from the sites in Singapore are limited to slightly more than two hundred Chinese copper coins, possibly one Javanese coin, and two coins of Sri Lankan origin (Heng 2006: I99). While these finds suggest that there were economic exchanges between Temasik and Java, China and South India, the quantity recovered is significantly lesser than those recovered from such sites as Kota Cina (late eleventh to late thirteenth centuries, North Sumatra), and similar to those recovered from such contemporaneous sites as Sungai Limau Manis (McKinnon I984: 362 \& 363). Comparatively, the volume and extent of trade that Temasik experienced was therefore lesser than that experienced by Malay ports during the previous two centuries. In addition, the quantity of finds also indicates that there was not much trade with China, reflecting the larger nature of Sino-Malay trade when China was under Yuan rule. The predominance of South Chinese materials in the archaeological remains suggests that Temasik economy was almost entirely orientated to South China. The Daoyi zhilue's record of Fujian sojourners in Temasik, and not any other Chinese groups, is consistent with the nature of the material culture recovered from the Temasik sites (Su I98I: 213). Finally, the economy was orientated towards the South China Sea and Java Sea, reflecting the place of South China, Thailand and Java as the key economic markets that were accessible to Temasik and the southern Malacca Straits during this time.

As a polity, Temasik was, unlike Srivijaya in the late seventh to early twelfth centuries, unable to proactively influence the trajectory of its fortunes. This passivity, or general inability, to exercise human agency may be seen in the maritime characteristics of the Temasik. The Daoyi zhilue indicates that ships approaching Singapore Island from Karimun Island to the eastern entrance of the Keppel Straits were subjected to pirate attacks (Su I98I: 213), indicating that Temasik, even with its Orang 
Laut subjects, were unable to maintain security in the waterways around its immediate vicinity. This is in contrast to the projection of Malay naval capabilities as recently as the twelfth century, when security in the Malacca Straits was brokered by Srivijaya, and all ships passing through that passageway had to call at its key port city (Tu I996: 42).

The presence of such material cultural remains as the Chinese copper coins, as well as a horde of gold jewellery recovered from Fort Canning Hill, suggests that Temasik was economically and culturally under the influence of Java (Winstedt I926). The political pressure exerted by Java on the small port polity is eulogized in the Sejarah Melayu as a series of stand-offs involving the prestige of the courts of Temasik and Java, which eventually culminated in the overrunning of Temasik by Javanese forces during the reign of Temasik's fifth ruler (Brown I970: 50).

Taken together, the conclusion provided by all these different sources of historical data relating to the various characteristics of Temasik as a polity in the late thirteenth and fourteenth centuries is that the nature of Temasik, as with all the Malay polities that were active during this period, was determined primarily by the regional contexts of Maritime Asia. More importantly, the functional aspects of Temasik were determined to a large extent by the regional and international contexts that the polity found itself in. Indeed, the larger contexts, which were beyond the mitigating efforts of the Malay region, predisposed Malay polities to be small, limited entities, whose internal characteristics, including their respective cultures, were influenced by the larger polities of Maritime Asia. Temasik's size, its currency, material culture and cultural traits, including the style of its jewellery, reflect the larger influences that it faced during its tenure of a hundred years.

The overwhelming importance of the regional and international contexts as factors affecting and determining Malay state formation may be seen in the eventual demise of Temasik in the early fifteenth century. As Malacca was able to capitalize on the changes in the South China Sea context, initially under the auspices of the Thais, and subsequently under the new tributary system instituted by the Ming court and facilitated in the first three decades of the fifteenth century by the Zheng He imperial voyages, the various Malay polities and settlements reconfigured themselves under the umbrella of Malacca.

The inability of Temasik's ruler to control the polity's fortunes is poignantly recorded in the Portuguese text, the Suma Oriental. According to this text, after Malacca was founded, the Malaccan ruler managed to broker an agreement with the Thais, whereby he would send an annual tribute to the Thai court in return for permission for Malacca to engage in international trade in the Malacca Straits, and for Singapore Island to fall into the economic sphere of Malacca. The Portuguese text notes that after that agreement, Singapore's economy began to be hollowed out, as 
traders and the island's population gradually moved to Malacca (Cortesao I944: 264). In this account, which differs significantly from that in the Sejarah Melayu, Temasik's fate was determined by its regional overlord, with no input or reaction from the polity. From that time on, Singapore Island became part of the Malaccan admiral's personal fief, and remained a minor outpost of Malacca and Johor (the successor of Malacca) until the arrival of the British in I8I9. Temasik's demise and Singapore Island's subsequent insignificance was therefore a continuation of the Malay state formation processes witnessed through the course of the first and second millennia AD.

\section{Conclusion: the maritime Asian realm and Temasik}

The above discussion indicates that pre-modern state formation in the Malay region has tended to be triggered by external forces, particularly those in the Bay of Bengal and South China Sea, and to a lesser extent in the Java Sea and Gulf of Siam. The combination of all these external forces created a variety of climates in which the polities of the Malay region then reacted to, taking on the various forms and functions that they did over the course of the first and second millennia AD. These included the nature, and the extent to which these polities grew or receded and the nature of their influence over the various sub-regions of the Malay world.

It is apparent from this discussion that, although much of the Malay region's experiences has been narrated as a single regional entity subsumed under various political entities over the course of time, the region was in effect the sum total of several sub-regions whose various polities were subjected differing operative environments, which in turn affected the nature of the polities that were formed. Scholarly attempts at coming to terms with the nature and process of state formation should therefore incorporate the larger regional and international contexts as part of the emerging historical picture. This imperative is particularly crucial, given that the length of time that almost all pre-modern Malay polities were active, with the exception of Srivijaya, typically did not exceed more than two centuries. Such an approach would put the notion of place and continuity in the nature of states in the region in a different perspective, thus aiding our understanding of the nature of the region's pre-modern social polity both at the micro and macro levels. In this regard, a continuous historical narrative of Malay state formation may be based not so much on a succession of port polities strung together in a chronological fashion, but as concurrent and at times overlapping circles of spheres of influences, differing political structures and economic centres, which were initiated, perpetuated or ended by the constant changes experienced by Maritime Asia. 
Such an approach is particularly important in furthering our understanding of Singapore's pre-modern past. In trying to come to terms with Temasik as an independent polity in the pre-modern Malay world, the anomalous nature of the timing and length of its existence present significant challenges to historians. This paper shows that, in order to surmount these challenges, it would be more fruitful to attempt to understand the state formation and characteristics of the port polity by re-orientating the nature of the enquiry on two fronts - from its time as merely an autonomous polity to the 'longue durée' of Malay state formation history; and from the indigenous or localised, to the exogenous or regional as the starting point of enquiry. Such a shift in the orientation of historical enquiry, from viewing the history of a polity with different lenses, one lens at a time, to viewing that history through several lenses simultaneously, would inevitably place Temasik in a much longer regional tenure that would consist of several parts or stages that occurred over the course of a significant period of time. As a consequence, while Temasik occupies a minor place in the overall narrative, its raison d'être and role during its tenure as a port polity is given rightful significance and coherence within the larger framework of regional and international contexts.

Indeed, the place that Temasik occupies in this paper reflects the reality that the history of Malay polities is a mosaic of several smaller narratives that may be set within the parameters of a regional and Maritime Asian 'frame'. In the process, Malay state formation history may be 'decentred', moving it away from the narrative of the ingenuity of human agency and importance of the port polity's functions in the region's international economy, towards locating it as a subset of a much larger canvas. While such a result may subvert the centrality of a specific polity's history, the short tenure of the polity's existence in the pre-modern era would nonetheless be suitably reflected in the 'longue durée' of the region.

\section{Notes}

I The author wishes to express his gratitude for the research funding and support accorded by the Isaac Manasseh Fellowship (Faculty of Arts and Social Science, National University of Singapore), and the generosity of the Department of History, National University of Singapore, in the summer of 2009 , which have made this paper possible.

2 These missions arrived in China between 670 and 673, in 695, 702, 716, 724, and between 728 and 742 .

3 Tanghuiyao, I00: I790.

4 Wang Yunwu, Ma Duanlin: Wenxian tongkao (henceforth WXTK) (Shanghai: Shangwu yinshuguan, 1936), 332: 2610; Tuo Tuo et. al. (eds.), Songshi, 489: 14089.

5 WXTK: 332: 2606, 3; Songhuipao jigao (Beijing: Zhonghua shuju, I957), Fanyi (henceforth SHYFY): 4: 97a-98a.

6 SS: 489: 14090 \& SHYFY: 7: 28 a.

7 WXTK: 332: 2610,3 \& SHYFY: 7: 55b-56a. 


\title{
3 The Singapore River/Port in a Global Context
}

\author{
Stephen Dobbs
}

There is little question that Singapore in the twenty first century is a global city that is heavily dependent on international economic forces for its existence, success and even failure into the future. Singapore meets many of the criteria to qualify for global city classification (Sassen I99I). At the same time it is also quite unique compared with other cities that might make similar claims. It is an island city state with no natural resources (beyond the much vaunted resource of its people), dependent on its neighbours and the global community for even the most basic commodities necessary for human survival, especially food and water. This dependence and connectedness with a wider global environment is not a recent phenomenon. Over the past couple of decades, debate about globalisation, what it is and what it means has often obscured the fact that interconnectedness and flows in terms of trade, culture, religion and politics have long been a 'global' reality (Frank I998). In the context of Singapore there is little doubt that in pre-modern times, such as during the Temasik and Singapura periods, it was already linked to various international trade, political and cultural networks by virtue of its place in the realms of the great regional kingdoms of Srivijaya and Majapahit, as testified to by various archaeological artefacts and documentary sources that have been uncovered (Murfett I999). Raffles arrival at Singapore on the $28^{\text {th }}$ of January I8I9 marked the beginning of another phase of global interconnectedness for the island as it took its place in modern history and became inextricably linked to and dependent on new global forces and waves of change. This chapter examines how the settlement and port of the island evolved along the Singapore River, linking the island to an international capitalist system and trading network during the first five decades after Raffles arrived. The changes brought about by this integration with a new global system would ultimately see Singapore become a prosperous home for millions of migrants from around the Asian region and the wider world. The same forces that shaped modern Singapore would see the world transformed ultimately from one of European hegemony, achieved via imperialism/colonialism, in terms of political and economic power, between the mid-nineteenth and twentieth centuries to one of independent nation states loosely bound together by structures and dependencies created in the previous century. These were 
processes that would involve and disrupt the lives of millions of people as new economic, political and cultural forces transformed traditional societies and states that faced the challenge of an expanding capitalist Europe and United States. The political, economic and cultural consequences of these global developments are still being played out.

When Stamford Raffles made a claim for the British East India Company on the island of Singapore in I8Ig, he had a vision of extending the commercial influence of the company and, by default, Britain throughout Asia. Singapore was ideally suited to the immediate purpose Raffles had in mind of securing a foothold for Britain in a part of the Malay world that others had already largely conceded was a stronghold of the Dutch (Raffles I991: 374-75). Singapore, situated at the southern tip of the Malay Peninsula, with a sheltered harbour for vessels travelling routes between India and China, provided the "inch of ground" (Raffles I99I: 374) Raffles needed for his imperial ambitions in Southeast Asia. For some time he had been concerned with what he said was Dutch aggression in the Malayan Archipelago and a whole litany of purported violations of agreements with local rulers as well as interference with British trade $^{\mathrm{I}}$. His view of the Dutch was that they were doing everything in their power to prevent the British from being able to carry on rightful trade in the archipelago. This was a period of intense rivalry, with the leading political and commercial powers of Europe competing to extend their spheres of influence, which were already global, ever deeper into Asia.

According to Raffles, England had behaved honourably in returning control of Java and the Moluccas to the Dutch following the end of the Napoleonic Wars in I8I4. By I8I9, however, Dutch efforts to restrict British trade were a key motivating factor in his quest for a British colony south of Penang and Malacca and ultimately establishing a trading factory on the island of Singapore (Wurtzburg I954: 519). Raffles was well aware of the strategic significance of Britain securing a geographic position for itself that would guarantee its growing East-West trade through the all-important Straits of Malacca. The trade with China had grown in significance for the balance sheet of the British East India Company by the early nineteenth century (Wong I960: II-I5) and a secure base in the region of Singapore was crucial to the company's future in the seas further east. As various acts of parliament in Britain opened maritime trade to allow greater freedom of passage for free traders and British cotton goods manufacturers sought bigger markets in China the pressure for a stronger British presence in the region grew (Wong I960: 3I-34). While Raffles was clearly driven by motives linked to the expansion of British colonial power and wealth he was also laying the foundations for what has now become one of Asia's most prosperous nations, still linked to sea-borne commerce through one of the world's busiest ports ${ }^{2}$ and now also a global commercial hub. 
The establishment of a port in Singapore cemented the island's place in the European imperial maritime trading system that was emerging in the nineteenth century. The island's central place in the international commercial system that emerged has been maintained by Singapore up to the present day. The new settlement grew at a spectacular pace despite the fact that it would be a number of years before British sovereignty would be legally recognised by the Dutch, their main competitors in the region. There was a very real fear for a time that the Netherlands would resort to force to try to dislodge the British from their strategic settlement at the southern end of the Straits of Malacca. The use of force would probably have succeeded if taken quickly enough, changing the course of Singapore's history and undoubtedly its modern status as a global emporium.

Not all of Raffles' compatriots shared his enthusiasm or vision for the place that Singapore would come to hold in Britain's eastern empire. The claim on Singapore exacerbated tensions between the two European maritime and commercial superpowers in the region and this was cause for concern amongst some of Raffles' contemporaries. The Government in India seemed indecisive and Governor Bannerman, in Penang, did not support the new factory idea because of personal feelings of rivalry towards Raffles (Wurtzburg I954: 475-524). Even Raffles' closest peers in the enterprise were not as sure as he of the island's destiny as a British factory and major global emporium. His old friend Colonel William Farquhar, who had been left in charge of Singapore, wrote to Raffles in I822 pointing out the precarious nature of the port's status and the fact that Raffles had himself given seemingly contradictory orders as to how the settlement was to be viewed, wavering between "extensive mercantile establishment" and later strictly a "military post”. Clearly, Raffles understood that the political future of the settlement was far from certain even whilst he seems to have clearly comprehended its future importance as a global trading centre. It was not until late I823 that the Advocate-General felt confident enough to state that "Singapore may now be fairly considered as a British Settlement" even though no formal agreement had yet been reached with the Dutch 4 .

For a brief time in Singapore official equivocation and the general sense of uncertainty it engendered hindered development of infrastructure for the port and town despite the fact that merchants and others continued to arrive. However, the ambiguity surrounding Singapore's political situation with respect to trade rivalry was resolved in March I824 with the signing of the Anglo-Dutch treaty. This agreement effectively demarcated the relative spheres of interest in the archipelago that were to be controlled by each power. The treaty was followed by a new agreement between the local Malay authorities and the East India Company, in August the same year, which effectively signed over Singapore and the 
surrounding islands to the 'honourable' company and extended Britain's imperial reach further into Southeast Asia ${ }^{5}$. By the time of this formal recognition of British sovereignty under existing international law, the settlement and port was already a magnet for merchants and a growing volume of international trade.

\section{The origins of a global emporium along the Singapore River}

With the vista of Singapore's expansive modern container terminals in mind, it is difficult to envisage the rather humble beginnings of this mega port along the Singapore River. Even in the early years of the settlement it was not uncommon for this tiny waterway to be described as a 'creek ${ }^{6}$. Nonetheless, this is where the modern mega port's roots lie. To speak of the port of Singapore or even the settlement of Singapore during the first fifty years of the island's modern history is to speak of the river, for on its banks was where most of all global goods traded in the settlement were handled and also where the physical centre of the town lay. The economic, political and social life of the young community literally developed on and along the Singapore River's banks.

The purely functional benefits of the river were quickly recognised by those charged with turning the vision of a regional port and global emporium into reality. It provided a safe avenue for the landing of cargo as well as a sheltered mooring for small craft. In fact, the river provided the only site for wharfage in the early years of the settlement?. It was particularly suited to the kind of regional commercial activity being carried on at the foundation of modern Singapore, which consisted of much bulky, low value, produce being imported or transhipped, then re-exported. Such cheap high-volume goods were more easily handled in the sheltered waters of the river. All the principal merchants who made their way to the settlement in the early years were unanimous in voicing approval of the river as the trading heart of the town. For example, Alexander Guthrie noted that the ocean front offered no protection or facility for trading activities and stated that in his opinion "the most eligible situation here for carrying on a general extensive commerce is the banks of the Singapore River" ${ }^{\text {. }}$. His compatriot D S Napier noted in a similar vein: "the Singapore River is certainly the best place adapted for carrying on trade, you have every convenience that can possibly be required for trading to any extent, and the facility with which boats can approach your godown to enable you to ship your goods" 9 .

The Singapore River had a very different shape and appearance to its present form. Even if the modern urban landscape were to be erased in an attempt to visualise what it was like in the past, it would be difficult to associate the snake-like symmetry of its current course with how it 
first appeared in those early years. Its shape and size have been radically transformed over the years and during the early years of the port's development in particular. To make the river an artery of international trade it first had to be contained and controlled. The north bank and a small hill near the present-day Fullerton Hotel, on the opposite side, were the only areas near the river mouth which provided ground suitable for the construction of buildings and landing platforms. The south bank beyond the rise at the river entrance was some nine feet lower than the opposite shore, resulting in what, at high tide, was a vast inland lake up to twelve feet deep, engulfing the entire China Town area as far as Pearl's Hill. This same area at low tide turned into a marshy bog unsuitable for building and certainly not practical for the landing of goods being transported from ships in the bay ${ }^{\mathrm{T}}$. As Raffles had already decided that the north bank of the river was to be set aside for government purpose ${ }^{\text {II }}$, the south bank had to be engineered to allow for the construction of portage facilities such as quays and godowns (warehouses). Without these engineered changes to the river system there would be no Singapore emporium. The problem of tidal overflow and flooding was to be overcome by embanking the river and backfilling the marshy south bank.

Initially, the main task was to construct a crescent-shaped embankment from the road opposite Ferry Point (Fullerton Hotel) to the proposed bridge (Elgin Bridge) ${ }^{12}$. The previously flood-prone south side was built up and reinforced to provide a permanent embankment between the river and the land behind. With the river thus contained, the hinterland could be drained providing, "expensive grounds... rendered permanently dry and salubrious" ${ }^{\text {"13 }}$. The huge amount of land fill required for this public works programme came from a small hill which stood where Raffles Place is today. An eyewitness account of how this was achieved is provided by Munshi Abullah, in which he describes how the hill was levelled by pick and shovel, an arduous job undertaken by Chinese, Indian and Malay labourers who were paid one rupee a day to carry the soil and stone to the reclamation site (Abdullah: 1970). The riverside land reclaimed in this manner was set aside for the business sector to conduct commerce and build godowns. The reconstruction of the bank was done so to create a natural wharf where lighters could load and discharge cargo. It was originally anticipated that between twenty to thirty spacious godowns would be created along this line (Logan I854: I08). In time this would prove to be a very conservative approximation of the space and needs of the port, as godowns and the associated trading activities extended the full length of the river, stretching for several kilometres. This work of levelling the hill and embanking the river took some time. When Singapore's second Resident, John Crawfurd, arrived in I823, the leading European merchants immediately petitioned that he continue this important river work, pointing out the difficulties associated with 
landing goods via the beach. Correspondence from various traders noted that for a "great part of the year" and at certain times every day, depending on the tide, there simply was no alternative but to use the river and the "facilities it affords" I4. The transformation of the river environment with quays and godowns was crucial to the development of Singapore as a major global port and trading centre.

By the time of Raffles' final departure from Singapore in June I823, much of the work of laying out a town plan for the fledgling settlement had been completed ${ }^{15}$ and the river was taking on the appearance of a major regional port with international connections. With the river thus contained and transformed, extensive building work commenced as communities of people from China, India and all over the archipelago world of Southeast Asia arrived to conduct business or to work in industries serving the port and island's commerce. One contemporary observer wrote about the feverish work in progress as follows: "we may soon look for a well-built town, with numerous and convenient wharfs along the banks of the river, or rather an inlet of the sea, contiguous to which the principal mercantile part of it is marked out, and already partly occupied with... warehouses" ${ }^{\prime \prime 6}$.

The river was now recognised as the centre of commercial activity and as the economic lifeline of the port colony. Resident John Crawfurd, under pressure to cut costs in the colony including the port works around the river, wrote to the colonial authorities in India highlighting the role of the river stating: "the existence of the river or rather creek of Singapore as the Government is already aware forms one of the most valuable and striking features of the place, as a commercial port" ${ }^{17}$. Though under explicit instructions from India to bring down the factory's expenses by halting public works, he authorised the completion of reclamation work along the south bank of the river and the levelling of the hill in what became Commercial Square (Raffles Place). In correspondence with his superiors, Crawfurd described as "impractical" the attempts to reduce expenditure in this way, as it would impede trade and the future growth of the settlement, which was not in the "best interests of the Government" ${ }^{\prime 18}$. The extent of work required is testified to by the fact that as late as 1858 there was more than one thousand acres of mangrove swamp within a quarter of a mile of the city's centre - the river (Wheatley I954: 64). Even into the I830s, sections of Boat Quay were still walled using "mangrove logs" (Norris I878: 6), suggesting this important work was still incomplete more than a decade after the settlement was founded.

By March I824 the number of brick-and-tile warehouses and shops erected for conducting business along the south side of the river had already reached twenty-six ${ }^{19}$. Many other plank-and-tile and thatch buildings also dotted the reclaimed land bordering the river. In the space of just several months the population living on the south side of the river had swelled to several thousand. The population increase and near 
instant success of the port pushed land prices in the best quarters of the town, including around the river, to between three and four thousand Spanish dollars per $\operatorname{lot}^{20}$. Where several years earlier there had only been jungle, swamp and mud, there now stood the completed buildings of Government and those of the more prosperous merchants. Economically and socially, the transformation of the river into a major emporium linking British trading interests with Asia and beyond was proceeding apace. A new landscape was taking shape around the river and the prosperous port with trading companies, shophouses, godowns and shipping.

As the town and population grew and spread out in relation to the demands of regional and global trade, the river was contained and transformed to accommodate this growth. All manner of businesses and housing spread along the river's banks as the number of people, attracted to the island by commerce, increased. The importance of the river as the lifeline of the settlement and port continued unchallenged over the next few decades. Improvements to the town and port facilities were made, with bridges being constructed between the two banks of the river and general road construction and various other public works undertaken.

By the I86os, the business sector - now housed around Commercial Square in impressive multi-storeyed buildings with adjoining Chinese enterprises running along South Boat Quay towards the new Elgin Bridge - looked across the river to where government offices stood with the Town Hall, St. Andrew's Cathedral and the Singapore Institution clearly visible behind them. In appearance, the town was a model colonial establishment. It was the "Queen of the Further East" (Earl I97I: I45). The development of the port away from the river in the latter part of the nineteenth century never completely displaced the underlying assumption that the river and surrounding area should be reserved for commerce. By the time the Suez Canal opened in 1869 and with the advent of the steamship revolution in the latter half of the nineteenth century, this small settlement and outpost of British imperialism had become a global port that could rival any other in the world, with the Singapore River still continuing to play a major role. The river's importance as a commercial artery and centre of the port city did not alter significantly until major urban renewal schemes got under way in the I970s and these developments, coupled with changes in technology, finally brought to an end the role of the river in Singapore's maritime history.

\section{The river's global trade}

As riverine development proceeded in step with the port's burgeoning trade, Singapore's geographical and other commercial advantages became clear. The island's fortunate geography placed it strategically on 
the main sea routes between east and west, making it an ideal location for a redistribution centre and market. However, geography alone does not tell the whole story of Singapore's success. Raffles had determined that the port of Singapore would be a free port and this more liberal trade policy helped ensure that Singapore stood out from rival trading ports in the region in what became an era of burgeoning global commerce ${ }^{21}$. Similarly, as new enterprises such as tin mining and plantation agriculture developed in Malaya and beyond, the port of Singapore became a key shipment point for these resources. Its location and status as a free port soon attracted vessels involved in regional trade from Siam, Malaya, Burma, Dutch East Indies as well as China and India. Thus, Singapore by virtue of its location, colonial policies and historical opportunity became a global entrepot. The governor of the Straits Settlements noted in a letter to Bengal in 1863 that "Singapore is a mere depot, where goods, the produce of other countries, are stored, until a favourable opportunity for their reshipment to their final destination." (Wong 1960: 159)22. It was surrounded by many states and islands, all within reasonable sailing distance of its shores. In the years of its foundation, when sailing craft literally "ruled the waves", Singapore's prime location made it a natural emporium for the region and world beyond. Vessels wanting to journey to countries east of the Malay Peninsula, such as Indo-China, Philippines, China and Japan had three main routes open to them during the Southwest Monsoon, all of which brought them within easy reach of Singapore (Wong 1960: 195). The port opened up trade to various states in the region which had previously not even considered the idea of "foreign trade" (Wong I960: 34), thus helping to incorporate even more regions into a global trade system. Singapore would be the emporium for many of these states' own goods and a collection point for trade goods from around the region and world. Consequently, the trade passing through the port quickly began to reflect the diversity of goods and produce emanating from virtually all points of the globe, as Northeast and Southeast Asia were integrated into a rapidly shrinking world and new global economic system.

With trade as the raison d'être for British occupation of Singapore, the river was the focal point of regional and global trade passing through the island for around half a century. Even as the port's trade grew and new facilities opened up at New Harbour (Keppel Harbour) to cater for technological changes and developments in shipping, the river would continue to play a vital role in the island's trading activities into the I980s. Singapore thus became a central port of call in Southeast Asia for sailing vessels of all nationalities, forming a vital link in the sea route between East and West. Its free port status and central location in the region proved an immediate attraction for maritime trade from China, Cochin China (Vietnam), and Siam, with annual voyages during the monsoon season being made to 
the island. Similarly, perahus (outriggers) and other craft from the archipelago world of Southeast Asia increasingly traded in the harbour. Like a magnet, the promise of free trade and convenience attracted all manner of shipping, and in a comparatively short space of time the flags of most European and Asian nations were to be seen flying over the harbour, which was "filled" 23 with sailing vessels and perahus of all descriptions. Throughout the I830s and 40s visitors to Singapore seldom failed to mention the large number of craft in the harbour or the amount of commercial activity which animated the river as "native vessels of all classes" moved to and fro between the anchorage and river quays (Bennett i967: I40). It seems Raffles had barely departed the new settlement for Bencoolen before Farquhar was writing to inform the Government at Fort Williams of how well received the establishment was by neighbouring merchants and traders. In a report brimming with conviction, Farquhar declared that, in spite of Dutch attempts to hamper the progress of the British factory, including the cutting off of fresh food supplies from nearby islands ${ }^{24}$, "everything has gone on in the most prosperous manner inhabitants are flocking in from every quarter" ${ }^{25}$. By late I820 Farquhar reported to Raffles:

It affords me the greatest satisfaction to be able to state to you that although scarcely one and twenty months have yet elapsed since the first formation of the port, [it] already far exceeds what Malacca could boast of during the most flourishing years of its long continuance in our possession. ${ }^{26}$

After giving details of vessels from various countries in the region, he added that Singapore had become “... the favourite rendezvous for all descriptions of Eastern traders" and that "cloths of various kinds of British manufacture are in great demand" 27 . The burgeoning cross-cultural commerce passing through Singapore and the general feeling of optimism continued, almost unabated, in the ensuing years.

It is difficult to determine the total volume of goods that were handled along the river, as no specific record of river trade distinct from other areas of the port was kept. However, based on the fact that the river was the principal area offering facilities for handling goods prior to the development of New Harbour, it is reasonable to suggest that the rising trade figures for the period I8I9-I860s largely reflect trade conducted along the river. As late as I864, there were only a "few godowns on the western side of the town" with their own wharves, taking some business away from the river and the central portage facilities at Boat Quay (Cameron I965: 58). While some commercial services opened in New Harbour during the I86os, more than three-quarters of all shipping business continued to be conducted along Boat Quay (Cameron I965: 57). The river trade was as varied as it was increasingly vast. 
The assortment of merchandise that passed through the port was staggering and evidence of the port's increasing global trade and status. In the early years of the settlement it was largely of a rather 'exotic' nature with much marine and jungle produce being recorded (Turnbull I989; Wong I960), while later in the nineteenth century primary commodities such as rubber, tin, copra and sugar became the main products transhipped through the port. In the early years the trade very much reflected the Chinese and Western demand for the natural produce of the region and beyond. An examination of the commerce of Singapore for this period reveals the port's dependence on such items as spices, ivory, dragon's blood (resin used for varnish, medicine and incense which is derived from various trees and palms), tortoise shell, sticlac, seaweed, sea cucumber as well as a multitude of other exotic items and of course the ever pervasive opium (Trocki I990; Turnbull 1989; Wong 1960) ${ }^{28}$. The godowns and shops that sprung up along the riverbanks were filled with such trade goods and produce from neighbouring countries and regions. The streets and alleys in the commercial part of the town were filled with the sounds of barter in a variety of languages and dialects and enlivened by numerous wares to be found on offer outside merchant's shops. Eye witness accounts clearly bear testimony to the extent and global nature of Singapore's trade from the earliest years. As one observer noted: "here you stumble at every step over the produce of China, and the Straits." ${ }^{29}$ There was a carnival-like atmosphere, which pervaded that part of town, a permanent "bazaar" as it was called by one observer "crammed", with the "productions of almost every nation in the world" (Yvan I855: 59).

Trading activity in Singapore was concentrated in two main seasons: "the junk season and the Bugis season" (Turnbull I972: 183). The socalled junk season saw vessels from South China arrive in Singapore between January and March each year. Their arrival was one of the most anticipated events on the Singapore calendar during the early decades of the settlement. Their arrival provided evidence of the settlement's success and its growing importance to global trade. The Chinese vessels came from all points along the mainland coast, from as far north as Shanghai, carried to Singapore on the Northeast Monsoon (Wong I960: IIO-III). The arrival of the junks each year marked the beginning of a notable increase in commercial activity, especially in the Chinese community. As soon as the first junk was sighted, a swarm of small craft would race out to escort it to the anchorage and runners would spread the news of its arrival through the town (Earl I97I: $365-367$ ). The excitement that surrounded the arrival of these junks was not without good reason, as the value of cargo that could be carried on a single junk was significant. One six hundred-ton junk from Canton in I824 had a cargo valued at between seventy and eighty thousand Spanish dollars. Another from Fukien Province, of two hundred-and-fifty tons burthen, had a cargo 
worth seventy thousand dollars ${ }^{30}$. These vessels mainly carried goods to meet the needs of the growing Chinese population in Singapore and surrounding islands and countries. The Singapore Chronicle reported on the volume and value of this trade in 1829 as follows:

The whole of the Chinese Junks for the season have arrived and the principal part, if not the whole of their cargoes are already disposed of... The number which have arrived this year, is eight, three from Amoy, and five from Canton; and they are of the burthen of from 250 to 400 tons. The import cargoes, of both the Amoy and Canton junks are very similar, and they bring the same articles, year after year, with little or no variation. The cargoes from Amoy are chiefly composed of - earthenware tiles - granite slabs - paper umbrellas - vermicelli - dried fruits joss sticks - joss paper - and a few nankeens, raw silk \&c., and are said to be of the value of from $\$ 30,000$ to $\$ 60,000$ Dollars. The cargoes from Canton, consist of the same articles, with the addition of - silk camlets - satins - camphor - sugar candy, and tea; and a much greater number of nankeens (in blue, green and yellow), and raw silk. ${ }^{31}$

The inventory of cargoes also often included such commodities and products as tea, medicines, twine, flour, crackers, paint and combs. A survey of merchandise carried to Singapore by junks over the years shows little variation in the type of goods shipped. Another important 'cargo' brought from China was people, known as 'flesh'. The legal and forced trade in human beings was profitable and played a major role in Singapore's commercial intercourse with China as millions fled their homeland seeking better lives abroad. Singapore became a clearing house for the traffic in human beings on their way to all parts of Southeast Asia where they would, if successful, set up businesses, but most often provide labour for mining, construction, plantations and various service industries, and, in the case of many women, brothels.

An important source of merchandise found in warehouses and on the wharves of the river was the archipelago itself. Collectively known as 'Straits Produce' the marine, agricultural, jungle and mineral products of the archipelago were a major component of Singapore's trade with China. The trade in these products formed the traditional basis of China's commercial links with Southeast Asia and created a monopoly for the junk traders (Wong I960: 51). Most of the export trade from Singapore consisted of Straits Produce and among the most desired goods from the region were edible seaweed, birds nest, tortoiseshell, gambier, gutta percha, sea cucumber, gold dust, ebony, shark fins, rattans, bees wax, rice, all manner of spices, tin and sandalwood. Like products that 
originated from China, there was always a certain amount of variation in what constituted Straits Produce, and, at different times, certain items took on greater importance than others in regional/global patterns of trade and exchange.

The Bugis of south and east Sulawesi were by far the biggest carriers of Straits produce to Singapore. Large numbers of their craft - between forty and one hundred tons carrying capacity - could be found in the outer roadstead during the 'Bugis season', which was between June and November each year ${ }^{32}$. Adept mariners and traders, the Bugis had traditionally traversed the archipelago collecting the natural produce of the seas and various islands for inter-regional trading. With the establishment of Singapore, much of what they collected found its way into the godowns along the river. Their voyages began with the start of the Southeast Monsoon and ended weeks or months later in Singapore, depending on how far they had travelled in the process of assembling their cargoes (cf. Pelras i996; Trocki i979).

There was a truly international and cosmopolitan feel to the port as its significance grew in tandem with trade flows. The official records show that a regular flow of Malay traders from Sumatra also made their way to Singapore carrying spices and other goods. Pepper, coffee and sago formed an important part of this trade (Moor I968: IOI-IO2). In I825 a fleet of twenty-five craft arrived in Singapore from northern Sumatra carrying two to three thousand piculs ${ }^{33}$ of pepper ${ }^{34}$. George Bennett witnessed a fleet of eighteen Sumatran prows arriving in the Singapore River in the I830s, loaded with unprocessed sago, and he reported that "regular fleets of ten or more" such craft were resorting there (Bennett ig67: 2I0). There was also a number of sailing vessels each year from Java which were called the "Arab ships", due to their being owned by Middle Eastern traders resident there. These craft, crewed by Javanese, carried large quantities of coffee, sugar and rice to Singapore (Davidson I846: $62 \& 63)$. Similarly, there were many smaller craft owned by Chinese working along the coast of the Malay Peninsula and islands close to Singapore. The Malay states provided a range of commodities that would become increasingly important to global trade including such items as tin, gold, cotton piece goods, black pepper, rattans, salt and aloes-wood (Wong i960: 78-82).

Continental Asia provided further trade products for Singapore's global emporium, in particular those from Siam (Thailand) and Cochin China (Vietnam). Until at least the I86os there was a steady stream of junks from both these countries sailing to Singapore each year on the Northeast Monsoon. Between I829 and I866 an average of thirty Siamese and seventy-eight Cochin Chinese junks arrived annually (Wong I960: tables IVB \& VB, 278-279). Their arrival and the principal goods carried by them were detailed in the Singapore Chronicle on a regular basis. For 
example, in 1824 it was noted, that thirteen Siamese junks had called carrying the 'usual' articles, including sugar, rice, salt, coconut oil, cast iron, culinary utensils and sticlac. The article also enumerated the cargoes of the Cochin Chinese junks that had arrived: "they have brought rice, sugar, raw silk, Tonkin lead, pickled pork, hog's lard and livestock". They also carried tea and other important items from China ${ }^{35}$.

Clearly the trade and commerce of the Asian region was central to Singapore's early and later success as a major port. However, the river/ port was truly a global entrepot and not simply a regional trading centre with growing quantities of goods arriving from Britain, continental Europe and North America. Trade with Britain and India was a particularly important factor in Singapore's early commercial success. Between I823 and I869 almost twenty percent of Singapore's total trade annually was with Britain while commerce with India accounted for a further seventeen percent (Wong I960: 255-256). It was after all a primary objective in establishing Singapore to further the commercial interests of Britain. John Cameron notes the extent to which European goods were readily available in Singapore; describing the scene along the riverfront in the I86os, he stated: "from morning til night may be seen the landing of huge cases, casks and bales of British manufactures, as well as machinery and iron-work of all descriptions" (Cameron i965: 57 \& 58). Commercial tables show the following articles as 'principal' goods imported from Britain, Europe and America: anchors and grapnels, arms, beer, canvas, copper sheathing, cordage, cotton twist, earthen ware, gold and silver thread, gunpowder, iron and steel, lead, paint, provisions, cotton piece goods, spelter, spirits, sundries, glass ware, wines, woollens and iron ware and mongery ${ }^{36}$. From India, the following marketable goods were found in Singapore: opium, piece goods, wheat, rice, gram, gunnies and saltpetre ${ }^{37}$. Opium and arms were particularly profitable and these were sold extensively to Chinese and Southeast Asians to finance the colonial enterprise. Singapore became the biggest drug (Wong I960: $27 \& 29$ ) and guns market (Turnbull I960: 179) of the archipelago. The scene along the river and in the outer harbour, as attested to by numerous contemporary accounts and illustrations, was one of intense activity as cargo carrying lighters and a variety of small craft carrying provisions and trade goods moved to and fro amongst the ships at anchor outside the river mouth.

\section{Conclusion}

By the time new wharfage facilities opened at the New Harbour on the Keppel Straits in the I86os, there were more than five hundred small craft moored in the lower reach of the river, near present-day South Boat 
Quay, which were devoted solely to transporting the trade of Singapore between ships in the harbour and godowns along the river. Though vulnerable to the vagaries of global trading and economic trends, by the I86os, the river/port of Singapore was one of the most important in the British Empire and a vital link in global trading activities. From the deck of a ship in the harbour looking to the river-mouth it would have been difficult to imagine the wilderness scene described by Farquhar only a half century earlier. The jungle-covered hills and shoreline had been replaced by impressive merchant houses and a growing number of public buildings flanked the river/port and prosperous commercial town centre. The post-Suez and steam era would usher in a new phase in Singapore's internationalisation and global connectedness, but the river's role in this global port continued to play an important role in the overall functioning of the port into the I970s. Much regional trade continued to pass through the river before being transhipped, often from the new deep water facilities at Keppel Harbour which was becoming a central focus of port activities by the I86os. However, the overall increase in trade from the late nineteenth century, which was indicative of the growth of global commercial activity in which Singapore has played a crucial part, meant that, even as the port's deep water facilities became more important, overall river trade continued to increase. As late as I959, Singapore's finance minister was telling the Legislative Assembly that the total amount of goods shipped via the river was greater than the total quantity of goods handled by the Singapore Harbour Board ${ }^{3}$. Though Singapore would remain part of a European colonial empire into the ig6os, by the i86os it was already a cosmopolitan and international hub, with a population made up of people from Asian, European and Middle Eastern descent. Its dependence on commerce and maritime trade meant that from its foundation it was a global port/city connected to a web of flows that have included not just commercial activities but also people and ideas.

\section{Notes}

I The Asiatic Journal and Monthly Register for British India and its Dependencies, I8I9, 7, pp. 206-I3.

2 The port of Singapore is one of the world's major maritime hubs. Methods used to quantify which ports are busiest vary depending on what is being measured. Typically, the measures used are total tonnage of goods handled, tonnage of shipping that passes through the port and/or total number of containers handled measured as "twenty-foot equivalent units" (TEUs).

3 Straits Settlements Records (SSR), Singapore: Letters to Bencoolen, Oct-Nov I822, L9, pp. I62-84.

$4 S S R$, Singapore: Letters from Bengal to the Resident, Dec I823-March I824, M2, No 23.

5 SSR, Singapore: Letters from Bengal to The Resident, November I823-March I824, MI, No. 50. 
6 SSR, Singapore: Letters to Bencoolen, Feb I8I9-I820, Lio, Singapore National Archive, pp. 23-24.

7 SSR, Singapore: Letters to Bencoolen, Jan-April I822, L7, Singapore National Archive, pp. I8I-83. This record contains a collection of letters from the leading European merchants.

8 SSR, Singapore: Letters to Bencoolen, Jan-April I822, L7, p. I83.

9 Ibid., p. I82.

IO SSR, Singapore: Letters to Bencoolen, Oct-Nov I822, L9, p. I92.

II SSR, Singapore: Letters to Bencoolen, Feb I8I9-Jun I820, Lio, p. 7I.

I2 SSR, Singapore: Letters to Bencoolen, Oct-Nov I822, L9, pp. 62-67, Report of the Land Allotment Committee.

I3 Ibid., p. 64.

I4 SSR, Singapore: Miscellaneous Letters In I823, BBI, pp. II7-I9.

I5 Of course much work would continue and the town plan that Raffles envisaged would be repeatedly modified out of practical necessity by those who followed him.

I6 The Asiatic Journal and Monthly Register for British India and its Dependencies, September I822, I4, p. 308 .

I7 SSR, Raffles: Letters to Singapore, May-Dec I823, Li9, pp. 286-87.

I8 SSR, Raffles: Letters to Singapore, May-Dec i823, Li9, pp. I54-59.

I9 The Asiatic Journal and Monthly Register for British India and its Dependencies, October I824, I8, p. 429 .

20 Asiatic Journal and Monthly Register for British India and its Dependencies, I823, I6, p. 246.

2I Having a free port meant the colonial state had to raise revenue via other means including opium revenue farms. For a comprehensive examination of the way opium helped finance nineteenth century colonial empires, see Carl A. Trocki, (1999), Opium, empire and the global political economy: a study of the Asian opium trade, 1750-1950 (Asia's transformations; London: Routledge).

22 SSR, Governor's Letters to Bengal, Jan I862-Feb I867, R44. See also, Lin Ken Wong, 'The Trade of Singapore, I819-69', p. I59.

23 Asiatic Journal and Monthly Register for British India and its Dependencies, April I820, 9. pp. 402-03.

24 Asiatic Journal and Monthly Register for British India and its Dependencies, September I820, IO, p. 293.

25 SSR, Singapore: Letters to Bencoolen, Feb I8ig-Jun I820, Lio, p. 24.

26 SSR, Singapore: Letters to Bencoolen, July I820-July I82I, L4, pp. 205 -06.

27 SSR, Singapore: Letters to Bencoolen, July I820-July I82I, L4, pp. 205 -06.

28 "Chinese Junks", Singapore Chronicle, 23/4/1829, "Chinese Junks", Singapore Chronicle and Commercial Register, 28/4/1831.

29 Singapore Chronicle, $15 / 2 / 1827$.

30 Asiatic Journal and Monthly Register for British India and its Dependencies, September I824, I8, p. 326.

3I "Chinese Junks", Singapore Chronicle and Commercial Register, 28/4/183I.

32 Singapore Chronicle, I/2/I824.

33 A local measure used widely in trading ports in Asia. I picul equals approximately 6o kilograms.

34 Singapore Chronicle, $17 / 2 / 1825$.

35 Singapore Chronicle, I/2/1824.

36 See for example, Singapore Free Press, 5/II/1835, Singapore Free Press, 26/II/1835, Singapore Chronicle, 29/12/1831.

37 Singapore Chronicle, 29/I2/I831.

38 Singapore Legislative Assembly Debates, I4/I2/1959, p. II74. 



\title{
4 'Walls of Illusion': Information Generation in Colonial Singapore and the Reporting of the Mahdi-Rebellion in Sudan, 1887-1890
}

\author{
Torsten Tschacher
}

\begin{abstract}
"News of what is going on in one corner of the world is quickly known in another corner." (Singai Nesan [Cinkai Nēcan], I3 May ı889: ı80).
\end{abstract}

\section{Introduction}

News spreading in an instant from one corner of the world to another this quote conjures up terms all too well-known in the world of the twentyfirst century: new media, knowledge-based economies, information technologies. But it relates to a time which few of us would think of in this manner: written in early I889 by a Muslim newspaper-editor in Colombo (Muslim Nesan [Muslim Nécan], 24 Cittirai ı889: 29) and reprinted somewhat later in a Tamil weekly newspaper in Singapore, with reference to events unfolding in the steppes and deserts of the Sudan. Surrounded as we are by the trappings of a technology which allows news to be transmitted almost instantaneously, it may be difficult for us to see the late-nineteenth century as experiencing its own 'information revolution'. And yet, at least as far as Singapore was concerned, in a sense this was the case.

There were two developments which helped transform Singapore's 'information order' in the late-nineteenth century (Bayly I996: 3-6). The new technology of the telegraph, which linked Singapore to Europe since I870, revolutionised the transmission of information. At the same time, a fundamental development took place in Singapore's newspaper market: the appearance of the first newspapers not printed in English, but in Asian "vernaculars", as they were known in the language of the time (cf. Birch I879). These newspapers all formed part of what Timothy Harper has called a "diasporic public sphere" in colonial Singapore, "a polyglot migrant world... in which communities not only had to find ways to relate to distant homelands, but had to learn to speak to each other, in many cases for the first time" (Harper I997: 263). 
Yet what role Singaporean newspapers played in this public sphere in the late-nineteenth century remains an open question. While important work has been done on the role of Singapore newspapers in the public sphere in the twentieth century (e.g. Chua 2008b), the early history of these developments still needs to be traced. Few studies of early newspapers in Singapore go beyond catalogues of newspapers and an outline of their individual histories. Vernacular newspapers are largely looked at in the context of their respective 'communities' (e.g. Chen I967; Roff I967), and, in particular, research on the Malay press has focused on the role of Malay newspapers in developing and formulating Malay nationalism. But very little work has been done on how the newspapers related to Singaporean society at large and the role they played in Singapore's inhabitants 'learning to speak to each other' is far from clear.

Historians have mainly been interested in two aspects of Singapore's early newspapers. One is the simple aspect of the newspaper serving as a primary source of information about Singapore's history. It is not at all surprising that one of the earliest histories of Singapore (Buckley I902) was mainly based on clippings from the Singapore Free Press. The other has been, as mentioned above, the newspapers' reactions to events which concerned their respective constituencies or communities. This chapter, rather than focusing on the way early Singaporean newspapers reported local events, will investigate how these newspapers related to an event in a region remote from Singapore's shores, namely the events around the movement known as the Mahdiyya, which had arisen in the early I88os in the Sudan and kept the British and Egyptian military busy until I898. As a movement of Muslim revival that had developed against the background of domination and exploitation of the Sudan by Egypt and its European administrators, the Mahdiyya had the potential to generate very different responses among Singapore's diverse diasporic communities. Which elements did Singaporean editors consider of interest to their readers regarding this movement and how did they make sense of it? How did they get their information and how did they evaluate it? And, finally, what does all of this tell us about the information order of late-nineteenth century Singapore? Are we witnessing a 'diasporic public sphere' in the making, or rather isolated publics engaged in a conversation with themselves?

In order to address these questions, I will discuss articles about the Mahdiyya published in Singaporean newspapers between I887 and I890. The period from I 887 to I 890 was important in the development of the Mahdiyya (cf. Holt 1977). While the original Mahdi had passed away in I885, his deputy, the khalifa Abdullahi, had begun to exert renewed pressure on Egypt as well as the British-controlled port of Suakin on the Red Sea, but the Mahdiyya were repulsed on both fronts in I888-89. At the same time, rumours of unrest in the Darfur region of western Sudan 
reached Europe, kindling hopes that the Mahdiyya might succumb to internal unrest. Finally, continued attention to the affairs of Sudan was guaranteed by the Emin Pasha Relief Expedition, led by the renowned explorer Henry Morton Stanley to rescue Emin Pasha, the German-born governor of Equatoria, the southernmost province of the Egyptian Sudan, who had been able to fend off the Mahdiyya forces. Yet the reason for focusing on the period between I 887 and I89o has above all to do with the vagaries of the archive. While vernacular newspapers were being published in Singapore since I875, it is not before 1887 that we actually have continuous copies of these vernacular newspapers. ${ }^{I}$ My discussion draws on three Singaporean newspapers, the English Straits Times, a daily, as well as the Tamil Singai Nesan and the Malay Jawi Peranakkan, both weeklies. The cut-off date of $\mathrm{I} 890$ is due to the closure of what was probably the newspaper that published most actively about the Mahdiyya in colonial Singapore, the Tamil weekly Singai Nesan.

\section{Singapore newspapers in the late-nineteenth century}

The late-nineteenth century was a crucial period for the development of newspaper publishing in Singapore. In this period, the Straits Times established itself as Singapore's main English daily. An even more momentous development was the emergence of a vernacular press catering to the majority of Singaporeans not educated in English. Within a rather short span of time (between I875 and I88I), newspapers were established in all of the three major Asian languages of Singapore, starting with the Tamil weekly Singai Varthamani in I875, the Malay weekly Jawi Peranakkan in the next year, and the Chinese daily Lat Pau in I88I (cf. Tan \& Soh I994: I-23; Turnbull 2009: I30-2). ${ }^{2}$ Newspapers in these languages came to constitute the core of vernacular publishing in colonial Singapore before the Japanese occupation of I942, though in the first half of the twentieth century, periodicals in other Asian languages were also published in Singapore as well.

A fundamental problem that seems to have beset all of the early vernacular newspapers in Singapore was to carve out a market for themselves. Among the Asian elites of Singapore, knowledge of English was fairly widespread, thus putting vernacular papers in an uneven competition with the English-language newspapers, while the habit of newspaperreading was not yet widespread among those who were more comfortable with their own vernaculars. Circulation was low in many cases. For the year I887, the Blue Book of the colonial government records circulation figures of I68 daily copies of Lat Pau and 300 weekly copies of Jawi Peranakkan and Singai Nesan, respectively, which are rather low compared to the 350 and 220 daily copies of the Straits Times and the Free Press, 
respectively (Colony of the Straits Settlements I888: Sa2). At the same time, the readers of vernacular newspapers were not confined to Singapore. Jawi Peranakkan had readers all throughout the Malay-speaking world, in Malaya as well as the Dutch East-Indies. Subscribers to Singai Nesan were found in the Malay Peninsula, Sumatra, Siam, the Mekong Delta, and South India, as well as Singapore. Similarly, Lat Pau had agents in many places throughout Southeast Asia (Birch I879: 53; Chen I967: 4I; Tschacher 2009: 60).

The main support for newspapers in nineteenth-century Singapore came from the mercantile elites of the respective communities and commercial interests also shaped the outlook of all these newspapers to a certain degree. The first publisher of the Straits Times was an Armenian merchant - Catchick Moses. Later, the paper was run for some time by its editor, Robin Woods, a law agent, and from I86I onwards by two ex-mariners, E.M. Smith and John Cameron (Tan \& Soh 1994: 3; Turnbull 2009: 85). During the period we are concerned with here, the Straits Times was very much the mouthpiece of Singapore's expatriate European settler community, a community as wary of attempts by the local colonial government to curtail its privileges as it was of the rise of Asian elites operating outside of its own ambit. While prepared to accept English-speaking Chinese as members of Singapore's public, Malays and "bullock-cart Klings," as well as their newspapers, were thought to be unfit to participate in the public debates of "an English colony" (Straits Times, II November I889; cf. Harper 1997: 282-6).

Yet the Asian-language newspapers were similarly rooted among mercantile and clerical strata of Singapore's society. Lat Pau was founded by See Ewe Lay, a comprador of the Hong Kong and Shanghai Bank, and it seems to have mainly targeted the local Chinese mercantile elite, to judge from occasional addresses to local merchants and its interest in trade policies (cf. Chen I967: 28, 45-9). The editor of Jawi Peranakkan, Muhammad Said, was a teacher and printer. According to Roff, "mercantile interests" defined most its readers (Roff I967: 51). At the same time, this paper was concerned with "vernacular education" and the standardisation of the Malay language, perhaps a reflection of the fact that it counted a number of Malay-language teachers among its audience, many of which were locally-born South Indians or of mixed Indian-Malay parentage. These were known in official publications as "Jawi Peranakkan", though the paper tended to identify them rather as peranakan kling in the period under consideration (cf. e.g. Jawi Peranakkan 20 Rabiulakhir I306/24 December I888; 9 Rabiulakhir I307/2 December I889; cf. Roff I967: 49-55; Turnbull 2009: I30-I).

This same class of people also played a role in the Tamil publishing industry. Muhammad Said had himself edited a Tamil newspaper for a short time in the I870s, while C.K. Makhdum Sahib, the owner 
of Denodaya Press and publisher of Singai Nesan, was apparently born in Singapore. ${ }^{3} \mathrm{He}$ had been in the printing and publishing business since the early i87os and had already edited two Tamil newspapers in Singapore before he established Singai Nesan in I887. As the lists of subscribers for Singai Nesan reveal, this newspaper was again primarily patronised by traders, though not exclusively so. While more than half of the subscribers had a mercantile background (especially trade in cloth and livestock as well as money-changing), at least a quarter of the subscribers were engaged in clerical occupations, often as cashiers or even peons (labourers) for various institutions. Almost 70\% were Muslims, though there were also a sizeable number of Hindus among them, predominantly from mercantile and landholding castes such as the Chettiars and Vellalars (Tschacher 2009: 60).

None of the early Singapore newspapers (and this is as true for the English as it is for the vernacular newspapers) would have been able to finance themselves through subscriptions and sales alone; even the Straits Times had nearly had to close down in I869 due to a fire, showing the precarious situation of journalism in nineteenth-century Singapore (Tan \& Soh I994: 3). Advertisements and notices were a source of additional income for all papers. With the Straits Times and Jawi Peranakkan, these usually filled the first page completely as well as a substantial part of the second page of these four-page newspapers. Furthermore, Straits Settlement newspapers in the late-nineteenth century were usually still closely connected with individual printing presses, which published books and other printed material as well as newspapers. Indeed, the editor of Singai Nesan, who was at the same time the proprietor of Denodaya Press, claimed in 1889 that he derived sufficient income from his printing press and that the newspaper was largely published for the benefit of the public than as a source of income (Singai Nesan, 24 June I889: I97; I July i889: i).

In the case of Singai Nesan, the roles of publisher, editor, and printer were still combined in one and the same person, whereas with both the Straits Times and the Lat Pau, the editor was an employee of the publisher, a development which had already taken place in Europe in the first half of the nineteenth century and which had an important impact on the role of the editor, as his or her autonomy increasingly became circumscribed by the interests of the publisher (Chen I967: 31; Turnbull 2009: 130; cf. Habermas I990: 275-8I). The case seems least clear in the case of Jawi Peranakkan, which was published by an association with Muhammad Said as its editor. Birch writes that the Jawi Peranakkan Association also set up the printing press, though prior to Muhammad Said's death in I888, the press seems to have been more commonly known as 'Saidi Press'. In an obituary published on the occasion of Muhammad Said's death, Singai Nesan noted that it was he who founded (stäpittu) the press 
and even called him (in English) the "proprietor" of the newspaper. Thus, it would appear that the situation regarding Jawi Peranakkan was similar to that of Singai Nesan, with one individual combining the roles of publisher, editor and printer, at least prior to I888 (Birch I879: 5I-2; Proudfoot 1993: 633; Singai Nesan, 25 June I888: 206).

While readers of today's newspapers are used to the idea that most of the content of the newspaper is written by the paper's staff, this was not the case in nineteenth-century Singapore. Singapore's newspapers at that time drew on a variety of sources for their articles. Besides Reuter's Telegrams (which the vernacular newspapers probably drew from the English press rather than subscribing to Reuter's themselves), these included articles from other newspapers, both local as well as foreign. Articles culled and translated from the Free Press and occasionally the Straits Times even formed a separate section of Jawi Peranakkan. Lat Pau and Singai Nesan similarly drew on Singapore's English press to augment their contents, but did not usually identify these items as such (Chen 1967: 37). By the end of the I880s, both the Straits Times and the Free Press also occasionally published articles from Lat Pau. But it would be wrong to assume that the vernacular press depended solely on the English newspapers for its articles. In autumn I887, for example, Jawi Peranakkan and Singai Nesan both reported a story culled from an Urdu newspaper from Madras (Jawi Peranakkan, 23 Zulhijjah I304/12 September I887; Singai Nesan, 24 October 1887: 72). Vernacular newspapers of the period were just as capable as English newspapers when it came to exploiting the growing number of newspapers world-wide as sources for articles, editorials and information (cf. Frost 2004: 86-7). For foreign news, all Singaporean newspapers, including the English ones, drew on news published outside Singapore. This is particularly true with regard to those articles which dealt with the activities of the Mahdi and his successor in far away Sudan.

\section{The Mahdiyya in the Singapore press}

In the period between June I 887 and June I890, the Straits Times published at least twenty longer items which in one way or the other related to the Mahdiyya, not including short telegrams. While this does not form a particularly large part of reported news, given that the Straits Times was a daily, the affairs of the Sudan nevertheless seem to have been regarded as important. Yet it formed a visible part among those news items which neither dealt with local events nor with news from the metropolitan centre. The Sudan maintained a certain visibility in the Straits Times throughout the period under consideration here - readers were regularly reminded of the existence of the Mahdiyya. 
The English press in Singapore was not the only institution to publish news concerning the Mahdiyya and the events in the Sudan and Egypt. Vernacular newspapers also sought to provide their readers with information on the topic. Of particular interest in this regard are the Malay Jawi Peranakkan and the Tamil Singai Nesan, since both newspapers were edited by Muslims, and had a largely Muslim readership, ${ }^{4}$ imbuing the topic of the Mahdi and later his deputy confronting Muslim states as much as Christian powers with a particular relevance. It is therefore surprising that the two newspapers exhibited very different approaches to the topic. Jawi Peranakkan hardly published any news about the Mahdiyya that was not taken from the English press. Beyond what was published in English newspapers, only a handful of short notes can be found, most of which consist of just one sentence (e.g. Jawi Peranakkan, I Jamadil Awal 1307/23 December I889). This is in sharp contrast to the interest in the events in the Sudan demonstrated by Singai Nesan. More than fifty articles going beyond the length of a telegram were published, some of them taking up almost a complete page of the newspaper. The number of articles about the Mahdiyya not only outnumbered those in the Straits Times - they also presented a different image of the conflict in the Sudan.

Of considerable interest are the sources of information used by Singapore newspapers in their reports about the Sudan. As mentioned, Jawi Peranakkan was largely dependent on the English press for its reports. The Straits Times at least seems to have had a correspondent in Cairo (cf. Straits Times, I4 October I887; i9 November i887), who wrote about Egyptian affairs, touching on the topic of the Mahdiyya occasionally. Most of the items in the Straits Times seem to have been written by the editor himself on the basis of telegrams (e.g. Straits Times, 3 December I888; Io July i889), while a few were taken from other sources, for example the English-language Egyptian Gazette (Straits Times, I December I888). While being largely dependent on telegrams, the editor of the Straits Times nevertheless made his own opinion about the events clear by commenting directly on the news received.

The situation looked different with Singai Nesan. At no point was news about the Mahdiyya the basis for the editorial at the beginning of the weekly edition. Rather, most items followed the section on Reuter's telegrams. Some of the items may well have been composed by the editor himself (e.g. Singai Nesan, 22 October I888: 64). However, Singai Nesan was clearly determined to make up for the fact that it had no independent means of gathering news about the Sudan in the form of a correspondent by drawing on as wide a pool of sources as possible. Some items were lifted directly from the Straits Times and given a special slant through additions and changes, as we shall see below. While such 'borrowings' from the local contender were usually not identified as such, the editor of Singai Nesan was keen to point out sources from beyond 
Singapore. These included references to Arab newspapers, both named and unnamed (e.g. Singai Nesan, 26 December I887: I07-8; 27 May I889: I88; I July I889: 4). But Singai Nesan's most important sources were the two main Muslim newspapers of the Tamil-speaking world at that time, Muslim Nesan and Sarvajana Nesan [Carvajana Nécan], both published in Colombo. No less than eleven articles about the Mahdiyya published in Singai Nesan were taken from Muslim Nesan, while Sarvajana Nesan contributed at least six articles with direct bearing on the events in Sudan. On one occasion, Singai Nesan published an article with an account of the death of General Gordon taken from Muslim Nesan which the Straits Times had received more than a month earlier "by German Mail" (Singai Nesan, 25 March I889: I52; Straits Times, I6 February I889), giving the impression that the editor of Singai Nesan preferred to publish an article with considerable delay in order to not appear to be dependent on the Straits Times for his news items. ${ }^{5}$

Both the Ceylonese newspapers used by Singai Nesan were of course themselves dependent on yet other sources for their reports about the Mahdiyya, but at least Muslim Nesan had a special asset regarding news from north-eastern Africa: Muslim Nesan's editor, M.C. Siddi Lebbe [Cittilevvai], was personally acquainted with the Egyptian nationalist leader Ahmad 'Urābī Pasha, who had been exiled to Ceylon by the British in I882 (Azeez I968-69: 759-60). This acquaintance made Muslim Nesan a particularly 'acceptable' source for news about the Sudan and Egypt, even more so since 'Urābī Pasha was known to be an acquaintance of the Mahdist general Osman Digna ['Uthman Diqna] (Straits Times, 7 January I889). As we shall see, the articles from the two Colombo newspapers published in Singai Nesan were anything but uncritical of British policy in the Sudan, providing a subtext to Singai Nesan's coverage of the events that complicates the relationship between Singapore's vernacular press and British imperial discourse in the late-nineteenth century. Reporting on the Mahdiyya thus provides an interesting starting point for probing the relationship between English and vernacular press in colonial Singapore.

\section{The origins and motivations of the Mahdiyya}

The Straits Times' ideas about the origins and aims of the Mahdiyya were simple: the Mahdiyya was a dangerous group of religious fanatics out to conquer 'infidel' countries. In the context of what has been written about British attitudes towards the Mahdiyya in the late I88os, this is somewhat surprising. In his study on Islam, Europe and Empire, Norman Daniel has argued that interest in the Mahdiyya had lapsed in Britain after I885. This, in his eyes, indifferent attitude towards the Sudan changed only in 
the early I89os, primarily through the agency of Sir Reginald Wingate, who had long experience of fighting in the Sudan, headed the Egyptian Military Intelligence after 1892 , and became Governor-General of the Sudan in I899 (Daniel I966: 426; Holt I977: 224). Wingate published his own account of the Mahdiyya in I89I, as well as translations of the account of two Austrians, who had escaped with his help from the Sudan in the I89os. These accounts were calculated to revive interest in destroying the Mahdiyya by identifying it as a group of religious fanatics rather than a proto-nationalist movement struggling against foreign domination.

Yet it is important that, as Daniel himself admits, "the legends to which he gave life already existed" (Daniel I966: 426), and they also existed in Singapore before Wingate published his account. An article published in the Straits Times reminded the readers that the Mahdiyya was "not only a political, but also a religious movement," and thus unlikely to make peace with those who did not share their creed (Straits Times, Io July I889). The Mahdi and his successor were commonly identified as "false prophets", while the "Dervishes", as the troops of the Mahdiyya were known, were usually characterised as "fanatic" (e.g. Straits Times, I August I888; 3 December I888; II December I888; 6 July I889; I0 July I889). There was certainly no trace of a positive evaluation of the Mahdiyya, as Daniel has found in some British accounts and novels, nor an idea of the Mahdiyya being primarily a movement against Egyptian imperialism (cf. Daniel I966: Chapter I5). It should also be noted that letters and notes about "How Europeans are Treated at Khartoum" from both of Wingate's Austrian informants had reached Cairo as early as I888 and were reported in the Straits Times (I August I888).

By and large, what was published in the Straits Times about the Mahdiyya between I887 and I890 conformed to what Daniel has written about Wingate, who "tended always to blame Mahdism specifically, although the tradition that he was exploiting was quite simply anti-Muslim" (Daniel ig66: 428). In the same vein, the Straits Times occasionally differentiated "Mahdism" from Islam in general, and even claimed that the "inhabitants of the Nile region... would, it is said, welcome a liberating army of Mahomedans" (Straits Times 5 January I889). Such statements, though, worked in two directions. On the one hand, they characterised the Mahdiyya as an aberration. Yet on the other hand, they reaffirmed that the people who had originally contributed to the success of the Mahdiyya were Muslims, and that the Mahdiyya, if an aberration, was nevertheless an Islamic aberration, thereby reinforcing through its use of the image of the "false prophet" with his "fanatic" followers existing negative stereotypes about Islam.

This becomes nowhere clearer than in a long article written by the Straits Times' Egyptian correspondent, which placed the events in Sudan in a wider context of disaffection in the Arab-Muslim world (Straits Times, 
I9 November I887). The article, entitled "A Mahomedan Crisis," begins quite innocuously by recounting the special reputation Cairo enjoys among the world's Muslims as a centre of learning. Yet not all is well in Egypt:

For some time past a deep under-current of bitter fanatic feeling has been running through the Mahometan world... Carriers from Mecca and Medina have been bringing in startling tales how Islam is rousing itself, how the preachings of excited dervishes in Arabia have stirred up that long-hidden fanatical feeling, which only finds a vent in deeds of bloodshed and destruction.

The main aim of this undercurrent, the writer asserts, is opposition to the Turks and ambitions to depose the Ottoman Sultan as Caliph and replace him with an Arab. The Mahdiyya is presented both as a result of this sentiment as well as providing an example to emulate:

What [the Arabs] will do will be to act as the Soudanese rebels, with whom every true Arab Mahomedan sympathises, and put to flight the armies of the aliens. We hear from all parts that the bold tribesmen of Arabia have expressed their sympathy with Mahdism, and they wish to do that which their congeners in the Soudan have put into practice under the leadership of the Mahdi.

This movement, the article stressed, posed not only great dangers to Egypt and Turkey, but also to Europe, if the "flood of fanaticism" were to be let loose. While in contrast to the original expansion of Islam, "Europe would not be endangered by such a flood" today, the interests of European nations in the Muslim world would certainly be, and that should be prevented.

Mass the descendants of the Saracens in the Soudan and give them the discipline and enginery of modern armies, and they become as terrible as gunpowder, if touched by the electric spark of religious fanaticism. With sympathy and aid from without, the Moslem world on fire, they would change the face of Egypt, for no ordinary force could stand before their fiery valour.

The article contextualised the Mahdiyya against the background of a number of threats perceived by British public opinion in the r88os. The first stirrings of Arab nationalism are here integrated with notions of Muslim revival and then blended with the centuries-old spectre of the Saracen induced by a violent religion to wage war against the infidel. Against this dark vision of a global Muslim conspiracy, the Mahdiyya assumes more threatening proportions than it ever attained in reality. 
This article, one of the longest published about the Mahdiyya in the period under consideration, would certainly have impacted the way the readers of the Straits Times evaluated events in the Sudan.

One of those who were obviously impressed by the article was the editor of Singai Nesan. Just two days after its original publication, a note appeared in Singai Nesan that a translation would appear in the next issue. The article, tellingly, was not identified as being from the Straits Times, but simply as what "a person" (oruvar) had written from Cairo (Singai Nesan, 2I November 1887: 87). The next issue duly carried the translation, though not without the editor introducing some subtle and not-so subtle changes (Singai Nesan, 28 November 1887: 9I-2). Already the title had been changed from "A Mahomedan Crisis" to the simple "Cairo." The changes in the text are even more telling. The "undercurrent of bitter fanatic feeling," which was observable in the Muslim world according to the English version, simply became "an idea of sorts" (or [sic] vitamāna ennam). Most tellingly, while the Straits Times warned that "the preachings of excited dervishes in Arabia have stirred up that long-hidden fanatical feeling, which only finds a vent in deeds of bloodshed and destruction," Singai Nesan presents its readers with the positive prospect that through the teachings of dervishes "all truths that have been forgotten" (maraintupōykkitanta unmaikal elläm) are being made known. Where the English article presents its readers with a gloomy conspiracy of world-shattering proportions, the Tamil translation tells the optimistic story of Islamic revival.

The alarmist warnings of the original regarding what impact a general wave of sympathy for the Mahdiyya could also have on European nations and the comparisons drawn with the time when "Saracen" armies swept away a largely Christian political order in the Mediterranean world are again largely absent in the Tamil translation. True, the translation also predicts the possibility of a "great disturbance" (perunkalakam), but its outcome would certainly have appeared as much more positive to its readers (at least the Muslims among them), than the one presented in the Straits Times:

... it seems as if the time is quickly approaching when perhaps a great disturbance will happen in the world, all Muslims unite, bring the affairs of religion into the pure, old condition, make a sultanate from amongst themselves, perceive someone from those of the lineage of the Lord of Prophets and make him Caliph.

However, Singai Nesan was not content to tell the story of the Mahdiyya through English eyes, even if modified. In August I889, when everyone was waiting for news of the great battle expected in the environs of Wadi Halfa, the paper published a two-part article originally printed in the Ceylonese newspaper Muslim Nesan with the provocative title: "Will the 
Dervishes Win?" (Singai Nesan, I9 August 1889: 28; 26 August I889: 32). ${ }^{6}$ Most of this article was devoted to an account of the events which had made the Mahdiyya possible and led to the present situation. According to the article, the problems began when the Egyptian Khedive Ismā'îl, covetous of the riches of the Sudan but unable to defeat the "obstinate Arabs" (murattarapikal), called in the English to help him. General Gordon subdued the Sudan and introduced harsh laws. On pain of punishment, "some parts of that country were reformed and slowly became stable." It was in this situation that the Mahdi appeared in El Obeid. His knowledge and piety attracted people to him and this made the Egyptian authorities uneasy. They called for troops, but were unable to defeat the Mahdi's followers. Next followed the English, who controlled the Khedive by now, but they were similarly roundly defeated: "It is easily imaginable for our readers how much blood of the English was spilled in vain in the Sudanese wilderness. So many renowned commanders of the English army were sacrificed" (Singai Nesan, I9 August I889: 28). Yet in the eyes of the article, the worst deed was actually that the English now decided to abandon the Sudan.

It it clear to the readers how debased a deed it was that the English sundered the Sudan, which had been conquered by Ismā'îl Pasha with much loss of life and wealth, from the Egyptian state and that they did not go after the Sudanese Arabs (Singai Nesan, 26 August I889: 32).

For, the article stated, the English actually had another agenda. As the Sudan brought much revenue to Egypt, it was clear that the Egyptian state would experience financial difficulties once sundered from the Sudan. While outwardly feigning sympathy, the English planned that, "after it had come so far that Egypt would be unable to pay its debts, they should take charge of that country themselves."

While this article clearly had its own agenda, it revealed a quite detailed knowledge of the events that had led up to the Mahdi's rebellion (cf. Holt I977: 32-5). While displaying some amount of sympathy for the Sudanese, and being restrained in its evaluation of the Mahdi, the real sympathies of the writer of the article nevertheless lay with Egypt. The Sudanese Arabs were described as savages, noble maybe, but in need of "reform" nevertheless, which was after all good for the stability and prosperity of their own country as well. 7 Yet the English were from the beginning only out for revenge and gain for themselves, which they ultimately realized could be achieved more easily by denying Egypt Sudanese revenues than by launching a war with an unsure outcome against the Mahdiyya. This seems directed at the relatively common claim on the part of the British government, that Britain was devoted to restoring financial stability in 
Egypt and that the Mahdiyya was the main obstacle to it (Straits Times, 5 January I889; cf. Straits Times, 9 May I890). Given that the article first appeared in Muslim Nesan, it is most likely that 'Urābī Pasha was the main inspiration behind it. Yet as much as the article criticised the actions of the English, in one important regard it agreed with the opinion of the Straits Times, namely, in regarding the withdrawal from the Sudan in the early i 880 os as a grave mistake.

\section{The exigencies of politics and war}

Reporting on the Mahdiyya in late-nineteenth century Singapore was not simply a matter of information. Newspapers were directly commenting on matters of policy when discussing the latest news from the Sudan. In particular, one thing seemed to be clear, at least to the Straits Times: that the decision to evacuate the Sudan in I883-84 had been a mistake. "When the inglorious scuttling of the British troops from the Soudan had been carried through under the second Gladstone administration, it was hoped that the Mahdi would rest from his labours and be thankful for having it all his own way in the interior" (Straits Times, II December I888). Yet, after enumerating the dangers which the Mahdiyya posed to Egypt, the paper concluded: "The policy of allowing the Mahdi free play has been tried and found wanting." The editor repeatedly lamented that British troops had failed to proceed to Khartoum in January I885 when they heard of General Gordon's death (Straits Times, 6 July I889; Io July I889). This "inglorious" British retreat was contrasted with the behaviour of the German-born Emin Pasha, who remained in the province of Equatoria and resisted the Mahdiyya: "three years after Gordon's death, his most trusted lieutenant was still devotedly and unflinchingly making head against the False Prophet” (Straits Times, I9 December I888). These statements came in the wake of parliamentary debates about sending British troops to support Egyptian soldiers against attacks by the Mahdiyya. The Straits Times noted: “The opposition in Parliament to the retention of Suakim has been strong enough to induce the Home Government only the other day to promise that no expedition there was at all involved [in despatching British troops to Suakin].” The editor of the newspaper was clearly on the side of those who proposed abandoning this policy, calling several times for campaigns against Dongola and even Khartoum itself, but also had to admit that there was opposition to such moves (Straits Times, 3 December I888; 5 January I889; I8 November I889).

In the articles appearing in Singai Nesan, things were not quite so clear. In general, the newspaper seems to have been cautiously in favour of deploying more British troops in the region. As mentioned above, the 
British were severely criticised for allowing the Mahdiyya to take the Sudan from Egypt by withdrawing their troops. When General Grenfell shifted his troops from Suakin to Egypt after his victory over the forces of the Mahdiyya there in December I888, an article which originally appeared in Muslim Nesan criticised this decision as improper, since the troops would still be needed in Suakin (Singai Nesan, 25 February I889: 136). ${ }^{8}$ Similarly, Singai Nesan published several articles largely based on articles from the Straits Times which advocated a greater British involvement in the affairs of the Sudan (Singai Nesan, Io December I888: 92; I7 December I888: 96; these are based on Straits Times, 3 December I888 and II December I888, respectively). But at the same time, some articles seem to urge greater caution. In April ı888, Singai Nesan remarked that there were still some parliamentarians who did not accept that it was wise to abandon Suakin, though "vain financial expenses and loss of lives" were happening to English and Egyptians alike (Singai Nesan, 30 April ı888: I80).

One important aspect in all of these considerations was the value and qualities of the combatants, English, Egyptian and Sudanese. The Straits Times generally held a dim view of the Egyptian soldiery, who were believed to be neither a match for the Mahdiyya nor particularly enthusiastic about fighting them (Straits Times, 3 December I888; II December I888). Yet at the same time, there were also reservations about endangering British troops in what was after all officially an affair of the Egyptian state:
But the British soldier is a scarce and valuable article and we cannot afford to "use him up" for any but the most necessary purposes. The Egyptian is not absolutely a hero, and we should be sorry to set a thousand of him in the open before half that number of the men who barred our road to Khartoum; but he can fire a rifle from behind a wall, and he can reinforce the police, and for present purposes in Egypt that suffices (Straits Times, II October i888).

Similarly, the troops of the Mahdiyya were generally seen as being successful only on account of their "fanaticism" and the fact that they stood against troops even less skilled than they were. Victories against them were taken as proof "that the fanatical hordes of the Mahdi cannot stand against disciplined valour" (Straits Times, 6 July I889; cf. also Straits Times, ig December I888). The superiority of British troops over their Mahdist counterparts also seems to emerge from statements in the Malay press (cf. Jawi Peranakkan, 27 Safar I305/I4 November I887). Yet time and again, the Straits Times was also forced to acknowledge the skill of commanders such as Osman Digna (e.g. Straits Times, 
I3 November I889), that "the Mahdists have a knack of rising up again after each defeat" (Straits Times, 28 September I888) and that "no matter how often beaten off, they returned to the charge" (Straits Times, II December I888). The latter quote was put into a more Southeast Asian context when translated by the editor of Singai Nesan, who compared this quality of the Mahdiyya to the Malays of Aceh fighting the Dutch (Singai Necan, I7 December I888).

On the whole, the articles published in Singai Nesan seem to present a much bleaker picture of British military prowess and consequently a better image of the abilities of both Egyptian troops as well as the Mahdiyya's forces. Indeed, when translating an article from the Straits Times, Singai Nesan predicted that despite the arrival of British troops in Suakin, the British would have difficulties in wresting the region from the Mahdiyya, whereas the English original had celebrated the arrival as "a significant turn of events" (Singai Nesan, I7 December I888: 96; Straits Times, II December i888). Yet the divergence becomes most salient in two reports about the battle of al-Jummayza near Suakin in December I888, which, like many articles critical of the British published in Singai Nesan, were taken from Muslim Nesan. The first of these articles stressed the importance of Arab troops in obtaining victory. A week later, an oral account of an English soldier was published, apparently received from the Central News Agency, in which the soldier complained about problems with the revolvers and the swords the British troops were using (Singai Nesan, I8 February I889: I32; 25 February i889: I36). Indeed, both news items had been published in the Straits Times, but rather inconspicuously: the news about the problems with revolvers and swords as a short notice and the positive evaluation of the Egyptian troops as a quote from the Queen's speech in parliament (Straits Times, 5 January i889). By giving prominence to news which had hardly been considered in the English press, Singai Nesan was highlighting a problem that was widely known though not always considered when publishing news about the Sudan in the Straits Settlements: the importance of unverified rumors in reporting about the Mahdiyya.

\section{The mists of rumour}

"We are ignorant of the truth in the affairs of the Sudan" (Singai Nesan, I3 May I889: I80; first published in Muslim Nesan, 24 Cittirai I889: 29-30). This was the exasperated conclusion of yet another article from Muslim Nesan which was republished for the benefit of a Singaporean audience. While telegraphy had revolutionised the speed of transmission of news around the globe, it had not solved the question of to what extent these news items were trustworthy. It was clear to everyone that information 
being transmitted from the Sudan was problematic and often contradicted the very next day by yet another telegram. "Reuter's telegrams... contrast strangely with previous advices," the Straits Times noted with more than a hint of disbelief when a telegram in September I888 announced the bad condition the garrison of Suakin was in, despite indications to the contrary (Straits Times, 28 September I888). Evaluating what happened behind enemy lines was among the most difficult of tasks. In the same article, the editor of the Straits Times noted about the Mahdist general Osman Digna that he "continues lively and troublesome, notwithstanding the many times rumour has killed him."

One way for newspapers to deal with the problem of rumours and untrustworthy news was to diversify the sources from which information was gathered and adopted. While English newspapers, with their subscriptions to telegraph services and foreign correspondents, were best equipped in this regard, vernacular newspapers tried their best to compete by drawing on information published in other vernacular papers which drew on sources unavailable to English newspapers or provided different perspectives on an issue. Singai Nesan's reliance on Colombobased newspapers, with their access to Arabic newspapers and the opinions of Egyptian exiles, is a case in point. But Singapore's only Tamil newspaper in this period was not simply a recycler of news from elsewhere; the flow of information worked both ways. For example, during I889, Sarvajana Nesan published a couple of articles expressly taken from Singai Nesan, Among these was a two-part article entitled "The Story of the Nile" (nīlarrin varalāru), which in itself was apparently taken from an Egyptian newspaper (cf. Singai Nesan, 6 May I889: I76; I3 May i889: I80; Sarvajana Nesan, Io June I889: 75-6; I7 June I889: 80). But this was an exception; for the most part, much like Colombo-based newspapers served Singai Nesan as sources for events in the Middle East, Singai Nesan and correspondents from Southeast Asia supplied Muslim Nesan and Sarvajana Nesan with information on events in eastern Asia.

Among these were news items which bore an uncanny resemblance to the war in Sudan. In Southeast Asia as well, colonial powers became embroiled in wars with local powers which were not always successful. The most glaring example was the protracted conquest of Aceh by the Dutch. For supplying news on the events in Aceh, newspapers in Ceylon drew on contacts in the Straits Settlements. During its first year of existence in I883, when it was still published from Kandy, Muslim Nesan had already published a long account of the war in Aceh which had been sent by "a Muslim" from Penang, a town which was directly connected to the war through refugees and smugglers (Muslim Nesan, 23 Cittirai I883: IIO-I; 30 Cittirai I883: I25-6; I4 Vaikāci ı883: I34-5; 2I Vaikāci ı883: I4I-2). Six years later, Ceylonese newspapers could also draw on the Tamil press in the Straits Settlements. Thus, a note quoted as being from Singai 
Nesan on negotiations between the Dutch and the Acehnese Sultan was published in Sarvajana Nesan (Sarvajana Nesan, 28 January I889: I2).

At the same time, they could still rely on correspondence from Penang regarding Aceh. In a letter published in Muslim Nesan later in I889, an anonymous correspondent from Penang likened the war in Aceh to "a game of little kids" (4 Purattāci ı889: I07). Nevertheless, it became clear that the correspondent's sympathies lay with the Acehnese, pointing out that "the distress of being afraid of the Acehnese is troubling the Dutch night and day," and that in a recent battle, the Acehnese had performed "admirably." By recounting the conflict over Aceh in this way, the correspondent described it in terms similar to the way that Muslim Nesan portrayed the conflict between the English and the Mahdists in the same period. In addition to the obvious benefits which the Ceylonese newspapers obtained from receiving independent information on the war by this means, this practice therefore also allowed Tamil Muslims in Southeast Asia to express unabashed sympathies for Muslim struggles against colonial domination and to draw parallels between them. While such a letter might have been difficult to publish in a Penang-based newspaper, its publication in Muslim Nesan would have ensured that it would ultimately be read in the Straits Settlements, where the Colombo-based paper also had an audience. In the process of trying to diversify their sources, vernacular newspapers also strengthened the formulation of a wider Muslim identity as the wars in Sudan and Aceh became part of a vernacular flow of information. It was certainly not by chance that the editor of Singai Nesan compared the Mahdists to the Acehnese, as mentioned above.

Nevertheless, independent sources did not protect newspapers from falling prey to unsubstantiated rumours and so newly-published information still needed to be subjected to close scrutiny. Among the most productive aspects of the events in Sudan, at least as far as its rumourgenerating potential was concerned, was Emin Pasha and the deeds of the Emin Pasha Relief Expedition led by Stanley. Emin was conveniently isolated in Equatoria and Stanley had to choose to approach Equatoria through the Central African jungle (a demand of the Belgian king, Stanley's employer), so that news about these two people was hard to get. When news spread in August I888 that a "White Pasha" was advancing down the Nile against the Mahdiyya, the Straits Times, after initial reluctance, jumped to the conclusion that it was Stanley assailing the enemies from the south. Yet the only evidence on which this conclusion could be based was "the persistence of the rumour" (Straits Times, 23 August I888; cf. I7 August i888). Singai Nesan and the Ceylonese Tamil newspapers on which the editor drew failed to be convinced by such rumours. The editor rather tended to believe the reports that Emin and Stanley had been captured by the Mahdiyya, "considering the situation in those parts and the news gathered with the Arabs" (Singai Nesan, 4 March I889: 140). 
A similar event was the supposed uprising of the important Sufi-Sheikh Muhammad al-Mahdī b. al-Sanūsī against the Mahdiyya in Darfur, which for a short time in early I889 triggered news that his followers had taken El Obeid and even Khartoum (cf. Straits Times, 2I February I889; Singai Nesan 20 May I889: I84; I July I889: 4). While "hopes ran high that El Sanoussi, a rival prophet, would overcome the Mahdi” (Straits Times, 6 July i889), the Tamil newspapers remained highly sceptical. The Colombo-based Sarvajana Nesan was quoted in Singai Nesan: "As countless telegrams like this about the Mahdists have come on many occasions earlier and turned out to be bare-faced lies within a few days, we will not believe this before proper news are published as evidence for this" (Singai Nesan, I5 April I889: I64; first published in Sarvajana Nesan, 23 March I889: 38; 30 March I889: 4I). In addition to the fact that such telegrams had turned out to be untrustworthy before, the evidence of the Arab press and what was known about al-Sanūsī was also quoted in Singai Nesan to counter hopes of a Sanūsī-uprising (I July I889: 4). In contrast to the case of Emin and Stanley, where the rumours of their capture by the Mahdiyya later turned out to be false, in this case the Muslim Tamil press was right to be sceptical: the whole matter turned out to be a localised conflict in Darfur (Holt I977: 157-9). But the Straits Times, rather than admitting that wishful thinking had made the English press throughout the Empire accept these rumours as true, preferred to claim that simply, "events have taken the opposite turn" (Straits Times, 6 July I889).

The supposed uprising of al-Sanūsī inspired what was probably the clearest exposition of the problems editors faced when reporting on the events in the Sudan. In a long article republished in Singai Nesan, the editor of Muslim Nesan lamented:

The Sudan is first among those countries one is unable to enter and gather true news. When seeing each and every day in each and every manner news about the Sudan coming in, it becomes clear that the things going on there do not reach the world in a proper manner. From the day the rebellion of the Mahdi began, there was not one among the news from the Sudan that was not contradicted or corrected by news that came afterwards (I3 May I889: I80; Muslim Nesan, 24 Cittirai I889: 29-30).

Not too little, but too much news was in a sense the problem editors were faced with. However, the article insinuated a further problem:

From the day the English got entangled in the war between the Mahdi and the Egyptian government, we know that news which came in about the unrest in the Sudan have been inspected in a 
few places before they reached us and have been corrected when the need was perceived.

In short, the article blamed the Egyptian and especially the English government for censoring, changing, and fabricating news. A similar charge had been made a few months earlier by Sarvajana Nesan regarding reports by English and Egyptian newspapers that Osman Digna had been defeated. Sarvajana Nesan advised its readers not to believe this claim lightly, pointing out that during the Crimean War a Russian general had covered up news about his own defeat by reporting a victory (Singai Nesan, I8 February I889: 132; first published in Sarvajana Nesan, I6 January I889: 7). While this article left it up to the reader to imagine a similar deed from the side of the British, the editor of Muslim Nesan found clear words to close his article: "The English... have raised a wall of illusion (māyaiyāna matil) between us and the things which we see. We are ignorant of the truth in the affairs of the Sudan." Many editors of vernacular newspapers in the British Empire would have agreed with him.

\section{Conclusion}

What does the analysis of reporting on events in remote Sudan tell us about the role of newspapers in Singapore's information order in the late-nineteenth century? The evidence reveals several asymmetries which impacted the way in which editors responded to reporting about a series of events that they could evaluate only on the basis of news gathered by others. In this, they knew themselves to be part of an information order far larger than Singapore. Everywhere in the British Empire, from London to Australia (cf. Singai Nesan, I July I889: 4), and beyond it, people commented on and evaluated what they had heard about the Mahdiyya and fed those comments into an ever increasing stream of news. Political interests, both those of the Mahdiyya and of its enemies, added further rumours to this stream, making it even more difficult for editors to decide which news to trust. The choice was far from being apolitical or neutral: it was part of a larger set of editorial policies, which were calculated to intervene in public debates, even if, on the part of the editor, neutrality was pure pretence.

In this situation, access to reliable information was crucial to staking a claim in the public debate about the Mahdiyya. The Straits Times had direct access both to Reuter's telegrams and to the occasional letter from a correspondent in Cairo. While the Malay Jawi Peranakkan seems to have remained content with being dependent on the English press in reporting on the Mahdiyya, the editor of the Tamil Singai Nesan attempted to redress the imbalances in the medial playing field by tapping into flows 
of information which would not have been as accessible to the English press. This included the opinion of non-English newspapers, both Tamil and Arabic, as well as information about Muslim networks and personalities, as revealed in the discussion about al-Sanūsī. Behind much of this stood the shadowy authority of 'Urābi Pasha in the form of articles by the Tamil press of Colombo, where the Egyptian nationalist leader lived in exile. Regarding the availability of alternative flows of information, Singai Nesan had an advantage over Jawi Peranakkan or even Lat Pau. There were neither many Malay nor Chinese newspapers in existence in the late I88os. In contrast, at least 35 Tamil periodicals, ranging from monthlies to dailies, were founded in I887 alone (Samy 2000: 130-42). But this alternative repository of information and opinion was Singai Nesan's only advantage in the context of Singaporean publishing.

In contrast to Jawi Peranakkan, with its large potential readership throughout the archipelago, and Lat Pau, with a sizeable Chinese community in Singapore, Singai Nesan was, like the Straits Times, catering to a small migrant community. Like the Straits Times, Singai Nesan was essentially a provincial newspaper compared to the press in London or Madras. The degree to which the editor of the Straits Times seems to have ignored this fact is striking. Throughout the period, the Straits Times reported on the issue of the Mahdiyya as if it was a big London newspaper shaping the outlook of a public which could influence the decisions that would be taken by the government regarding the Mahdiyya. In reality, of course, despite all its counselling and supporting various policies, the Straits Times was a minor voice from a remote outpost of the empire, which would be heard in London only long after the decisions had been taken, if it was heard at all. Reporting on the Mahdiyya removed the Straits Times further from its Singaporean context by allowing it to imagine itself and its readers as part of an infinitely wider metropolitan public.

On the vernacular side, there is relatively little sense of coverage about the Mahdiyya contributing to the way the nascent publics created by vernacular newspapers imagined themselves. The Malay press seems to have not taken much interest in the matter, while on the Tamil side, Muslim editors may have felt sympathies for the Mahdiyya's struggle against the British, but tended nevertheless to favour Egypt and the Ottoman Empire as recipients of Muslim loyalties. If anything, the conjunction of news about the Mahdiyya with those about other Muslim struggles against colonial powers, such as the war between the Dutch and the Acehnese, helped to sharpen an idea of a wider transnational Muslim community beset by colonial policies. While the images of Muslim revivalism transmitted in the course of reporting about the Mahdiyya may have contributed to a greater receptivity regarding this topic among Muslims in Singapore, they certainly had much less of 
an impact than, for example, the coverage of Meiji Japan had on the formation of "Islamic nationalism" in the Dutch East Indies (Laffan 2003: I60-5). True, the criticism levelled against the British in the articles published in Singai Nesan was substantial for its time, but it would be wrong to portray it simply as resistance to a British colonial order. Much more, reporting on events occurring beyond the confines of Singapore was an attempt by the nascent vernacular newspaper to communicate with the established English press as equals, a first effort at "learning to speak with each other" (Harper 1997: 263) and attempting to overcome the limitations and fragmentations of Singapore's public sphere.

Yet the case should also alert us to the fact that fundamental questions about the nature of the public sphere in colonial Singapore still need to be addressed. As this article reveals, the Habermasian idea of the public sphere as a sort of middle ground between the private and the state is problematic in a situation of empire, where the state can be imagined both in terms of the local colonial government and the overarching imperial structure. Reporting on the Mahdiyya allowed vernacular editors in other parts of the British Empire to voice criticism against a proxy, namely British imperial policies in north-eastern Africa, without having to implicate their own governments in Singapore or Ceylon directly. Mark Frost has noted similar tendencies among the Chinese settled in Southeast Asia (Frost 2004: 89-90). Frost's highlighting of the importance of maritime linkages for the development of a colonial public sphere are highly pertinent in this regard. Singapore's colonial public sphere - almost from its inception reached beyond the confines of the island, connecting to other parts of the Empire way beyond the places where Singapore's cosmopolitan population had links.

\section{Notes}

I This was clearly due to the effects of The Book Registration Ordinance I886, which came into operation on I January I 887 and required printers to deliver three copies of every book printed in the Straits Settlements to the government (Garrard I898: vol. 2, 967-9).

2 Tan \& Soh (I994: 22) claim that Singai Varthamani [Cinkai Varttamāni] was first published in 1876 . Yet an article published in 1890 by the editor of Singai Nesan, who had after all also edited Singai Varthamani, states that this paper, of which no copies are extant, was originally founded in I875 (Singai Nesan, 9 June I89o: 186).

3 This is suggested by the title page of a Tamil book printed at Denodaya Press (Cevattamaraikkāyar I886). I wish to thank the Roja Muthiah Research Library in Chennai for allowing me access to and supplying me with copies of this book.

While the readership of Jawi Peranakkan, as a Malay newspaper, would have been overwhelmingly Muslim, the readers of Singai Nesan of course also included Hindus and 
Christians. Nevertheless, as the lists of subscribers reveal, there was a clear Muslim majority among the subscribers.

5 The article in Muslim Nesan was apparently itself a translation of a local English newspaper, the Lanka Examiner (6 Pankuni I889: 4).

6 The second part of this article was first published in Muslim Nesan, 3I Āti I889: 85-6. The first part was apparently published a week earlier, on 24 Âti I889, but this issue is missing at the Department of National Archives in Colombo, Sri Lanka.

7 The Sudanese Arabs are described as 'obstinate' or 'rough' (murattu) and 'savage' (kättu, literally 'of the forest'), exactly the terms used in South India for communities perceived as 'criminal', such as the Kallars (cf. Pandian 2009: 35-40).

8 This article appears to have been published in volume 6 (I888) of Muslim Nesan, of which no copies seem to be available anymore. 


\title{
5 The Littoral and the Literary: Making Moral Communities in the Straits Settlements and the Gold Coast in the late Nineteenth and Early Twentieth Century
}

\author{
Philip Holden
}

In late 2009, I returned to Singapore after several months abroad. Eager to catch up on the popular history I had missed, I started browsing in the relevant section of Borders on Orchard Road. I picked up, not without some effort, the weighty 8oo-page Men in White: The Untold Story of Singapore's People's Action Party. Opening the first few pages, I scanned its table of contents. The name of a single politician, understandably, was prominently featured early on in the story, yet he kept returning and returning, almost two decades after he stepped down as prime minister of Singapore. "Can PAP," the book's authors wondered even in their last chapter, "survive LKY?" (Yap, Lim and Leong 2009: 64I).

Historians in Singapore over the last two decades have, of course, worked to problematise the identification of a national history with a single life. Kevin Tan's and Lam Peng Er's Lee's Lieutenants (I999) was an early attempt to tell the stories about other prominent politicians in Singapore's governing party since independence; much recent work in both history and memoir has concentrated on the period of decolonisation from the late I940s to I965 and told the story of political actors who have often been excluded from - or misrepresented in - the national narrative. ${ }^{I}$ Further studies have questioned the building blocks that serve as a foundation for national story-telling: the division between the 'Chinese-educated' and 'English educated,' for instance, or between 'Communist' and patriotic nationalist. ${ }^{2}$ Taking a longer perspective, Kwa Chong Guan and others have placed Singapore's colonial and post-independence history within a much longer narrative of the island's situation as a node in networks of trade. According to this view, Singapore's history is cyclical, rather than linear, intimately connected to the region in which it is located, and a product of negotiation between communities rather than the fiat of colonial governors or post-independence prime ministers.

Yet, for all such historical revisionism, popular history in Singapore often defaults to a focus on Stamford Raffles and Lee Kuan Yew as representative figures in a developmental narrative. In this paper, I want to trace the 
roots of what we might call a popular national imaginary in Singapore. In doing so, I am particularly interested in examining how the concepts of cultural difference and community were made use of in the emerging selfidentification of para-colonial elites as moral communities in the Straits Settlements in the late nineteenth and early twentieth centuries. These elites, we will see, have largely been disavowed in nationalist historiography. If we return to them, however, we will learn much about the formation of modern communities during an earlier period of globalisation, and in particular two elements of their self-constitution that remain as their legacies in Singapore today: the manner in which the modern individual and the new community operate as moral signifiers for each other, and the manner in which culture comes to be reconstructed and defined as a moral good under modernity.

In examining elite Anglophone discourse on the moral community, I make two further strategic moves. The first is comparative: this essay looks not only at the Straits Settlements, but also at contemporary elite self-constitution at a similar period in another British colony geographically remote from Singapore, the Gold Coast. To a degree, the choice is arbitrary: similar conclusions might be drawn from the study of other indigenous or migrant elites in other areas of the British Empire, such as India or Hong Kong. Yet the Gold Coast does have connections with Singapore. There were commonalities in colonial leadership: from I895 to I920, the Gold Coast had three governors with extensive prior experience in Malaya or the Straits Settlements and whose names are inscribed onto the landscape of postcolonial Singapore: William Maxwell, John Rodger, and Hugh Clifford. The two countries' experience of decolonisation also went in parallel. The year I957 marked not just the independence of Malaya, but also that of the Gold Coast as Ghana: the centres of the two new national capitals, Kuala Lumpur and Accra, became the sites of modernist buildings which embodied the promise of the newly independent states. Two years later, the People's Action Party came to power in Singapore in I959 as a socialist party with strong links to national liberation movements in Africa and Asia. Lee Kuan Yew, as first Prime Minister of independent Singapore, knew Ghana's first Prime Minister and later President, Kwame Nkrumah and indeed sent him a letter of condolence after he was ousted in a I966 coup, praising "the vision and unity which you strove" and expressing the continued hope that "what you stand for, a united Africa and a great Ghana, [would] triumph and flourish" (Milne I990: 24). Yet historical developments over the last half century have resulted in Africa in general, and Ghana in particular, coming to stand for failed modernity within nationalist discourse in Singapore. In his memoirs From Third World To First, looking back three decades, Lee now only remembered the excesses of the end of Nkrumah's regime, seeing Ghana's failure as a developmental state due to "tribal 
loyalties" exceeding a "sense of common nationhood" and exacerbated by the absence of "long years of training and tutelage in the methods and discipline of modern government" (Lee 2000: 399). The way this chapter plots parallel elite histories and historiographies that have diverged to the extent that they are now incommensurable may help us to question the manner in which history is scripted and indeed to think through the ideological 'common sense' that equates modernisation with the disciplinary culturalism on which it is based.

If the importance of para-colonial elites has been excluded from nationalist historiography, much the same might also be said of the types of the historical text this chapter concerns itself with. Nationalism and the novel have often been closely associated, both in projects to create a national literary canon in post-independence periods and in retrospective scholarly accounts of the construction of national imaginaries. This chapter, however, looks at more ephemeral and less monumental forms of literary production: poems, biographical essays, and serialised fiction published in newspapers or magazines over which members of these elites exerted editorial control. Concentrating on such texts has two advantages. First, they are part of tight circuits of production and consumption. Early novels written by West Africans and members of the Straits Settlements elites were often published abroad: Joseph J. Walters's Guanya Pau (I89I) in the United States, J.E. Casely Hayford's Ethiopia Unbound (I9II) in London, and Lim Boon Keng's Tragedies of Eastern Life (1927) in Shanghai, whereas newspapers and magazines, in contrast, were read locally and regionally, and drew their contributors from a more tightly-bound local community.

Second, the brevity of such writings makes it easier to question the ideological field in which they are situated than is possible within the longer narrative of the novel. The novel in a single volume is immersive, drawing the reader away from a social world for hours at a time. Reading short stories, poems, and serials, a reader must continually surface into a social world as each piece ends. The effect, in contrast to the composed picture of the novel, is one of a fragmented, multi-perspective collage. Thus short literary narratives, while at times enforcing social and ideological norms, also offer readers the ability to question them. Their formally literary qualities distance or defamiliarise readers from the events that they describe, creating the paradigmatically modern experience, in Theodor Adorno's words, of not being "at home in one's home" and thus opening up a space for questioning the process of historical representation (I974: 39). It was perhaps in this respect that the anti-colonial activist and short story writer Frank O'Connor referred to the short story as expressive of a quintessentially modern "attitude to life" (2003: I); its brevity, he argued, extracted it from larger ideological fields. If the novel, by its nature, needed to present a vision of 'normal society' to which its 
protagonists might respond, the short story centred on a moment frozen from a larger narrative - frequently the product of a specific "submerged population group" and such stories dramatised an intense "awareness of human loneliness" (2003: 5), promoting a certain remoteness from a sense of community. This negotiation between individual and community at the formal level may be useful when we think about the metaphorical connection between community and individual that para-colonial elites strove to make.

\section{Making the Moral Community}

The Gold Coast and the Straits Settlements in the late nineteenth century had emerged from parallel histories of trade, followed by colonisation by a succession of European powers before finally gaining formalised status as British Crown colonies. ${ }^{3}$ In the Gold Coast, African polities had coalesced around forts set up by European powers and had then gained autonomy from inland states, with representatives of different groups jostling for overall political control. Missionary activity from the I830s onwards resulted in the formation of Creole mercantile elites who were literate in English and contemporary writings often make a distinction between the 'better' and 'poorer' or 'literate' and 'illiterate' classes; this distinction was reinforced by the selective adoption of European dress and by 'residential segregation' according to class in coastal towns such as Cape Coast and Accra (Gocking I999: 54). Crucially, the formation of the Gold Coast elites was not simply a process of Anglicisation. One scholar has noted that a parallel process of "Akanisation" took place, in which, through mechanisms of colonial indirect rule, the hierarchical structures of Akan polities were privileged over the looser social groups of ethnic groups such as the $\mathrm{Ga}$ and the Ewe (Gocking I999: 4).

By the late nineteenth century the Gold Coast elites were well established in towns such as Accra, Cape Coast, and Elmina. While many elite families could locate a European trader in their family tree, they had, if anything, become more African as the century progressed. West Africans from the Gold Coast or Sierra Leone occupied most of the positions in colonial service, including many senior ones. Indeed, on one occasion in the I88os seven of the nine district commissioners in the colony were Africans (Gocking 2005: 4I). Yet in the late nineteenth century the elites were also subject to new pressures. Renewed racism and a growing emphasis on the partially invented traditions of indirect rule resulted in Africans being removed from positions of authority in the colonial service, perhaps most clearly epitomised by Governor William Maxwell's dismissal of John Farrell Easmon from his position as Chief Medical Officer in I897 (Patton 1989). At the same time, the rise of a 'scholar' class of 
primary-school educated Africans threatened the 'native gentlemen' of the elite from below (Gocking I999: 59). The elite's literary societies and clubs, which were established in most of the coastal towns in the I89os, their social rituals, the newspapers they published, and their participation in an albeit circumscribed colonial public sphere have been seen by one scholar as an active negotiation with acquired cultural capital, their imitation and appropriation of elements of English culture considered a pragmatic and "highly selective performance of an identity which was adopted at strategic moments to secure their social and economic position" (Newell 2002: 33). Yet if Englishness was performed, so was a modern African identity. the community imagined various circles of proto-national identity (Fanti, Aborigine, West African, and African) as it attempted to discover a locally-inflected modernity.

The Straits Settlements also emerged not simply from acts of imperial foundation but from a history of trading networks into which European powers gradually inserted themselves. As with the Gold Coast, the islands and littoral settlements of Penang, Malacca and Singapore did not formally become a Crown Colony until the second half of the nineteenth century. ${ }^{4}$ The British "Forward Movement" and imposition of indirect rule over the Malay States of the Malayan peninsula in the late nineteenth century has parallels with British movement inland into Asante on the Gold Coast: the ports of the Straits Settlements, like those of the Gold Coast, had hybrid populations and non-European political organisations that supplemented the rule of the colonial state. While these communities have often been seen as distinct, recent historical research has suggested the importance of a heterogeneous but nonetheless identifiable Anglophone community of Asians in Singapore, in particular. ${ }^{5}$ This chapter concentrates on the Straits Chinese, a hybrid community of residents of Chinese descent in the Straits Settlements which absorbed cultural elements of both Malay and European culture, and whose members often served as a comprador class in the colony. While the contemporary heritage industry in Singapore tends to fetishise Straits Chinese or Peranakan identity through the markers of clothing, food, and custom, recent historical research has suggested that the category of 'Straits Chinese' in the late nineteenth was much more fluid than is now popularly thought. Historian Mark Frost has conceptualised the Straits Chinese as a "transcultural diaspora", in which a public performance of Chinese identity masked a hybrid social reality (2003: 2). Similarly, sociologist Jürgen Rudolph has described Straits Chinese community identity as historically situated, moving from a largely political identity under colonialism to an ethnic one in contemporary Singapore (I998: 67). As we will see, elements of the Straits Chinese also sought other identities that would reach beyond ethnicity in the colonial public sphere, at times campaigning on behalf of all "Straits-born" subjects, or reaching out to a community of "Asiatics" 
("Our Programme" I897: I; "Editorial" I905b: 4I). Like the coastal elites in Ghana, the Straits Chinese sought to create a culturally inflected modernity expressed at least partly through the English language that invoked a new relationship to tradition. The quarterly Straits Chinese Magazine, for instance, saw its purpose to 'restore' to all Straits-born people "the knowledge of their forefathers in English dress" ("Our Programme" I897: 2). The scale of recent indentured migration and the presence of a cultural although not political - homeland far away from the colony itself did, of course, make the details and context of cultural performance different for the Straits Chinese compared to their Gold Coast elite counterparts. Nonetheless, we can see significant parallels: the presence, for instance of literary and debating societies, and also difficulties in working with less and less room for political manoeuvre, as race became a increasingly important mechanism in colonial governance, exemplified by the colonial authority's ambivalence regarding non-European participation in the Straits Volunteer Force.

The socio-political concerns of elite communities of this period in the Straits Settlements and the Gold Coast appear unusual when viewed from the present, across the historical watershed of decolonisation. While they demanded equal treatment for all colonial subjects, they frequently did so through elaborate effusions of patriotism, requesting, in the words of a Straits Chinese Magazine editorial, that there be "strict and impartial administration of justice" by the colonial authorities, but rarely questioning the legitimacy of the colonial order itself ('Editorial' I905a: 6). A poem representing an imaginary history of the Fante people that was published in The Gold Coast Leader in I9O2 describes a search for liberty in opposition to "mightier foes" such as the Asante. Although European colonialism involved the past imposition of "might o'er right," it might yet be reformed through recognition of the equality of all peoples:

England at last becomes the mistress

Of all our coast, Assinee to Volta,

Confederate as Aborigines strive to stand,

Safeguard our rights our customs all.

We seek our rights not ungrateful

To sing with Her, 'God Save the King.' ('The Fanti Land' I902: 4)

The Straits Chinese Magazine, similarly, published a black-bordered editorial to mark Queen Victoria's death in I9OI, lauding in the monarch's reign a "peaceful transition" in the British empire from "the regime of personal rulers to that of a pure Democracy united by allegiance to a constitutional head" ('Her Late Majesty' I9OI: I). An accompanying poem expressed hope for the continuation of both nation and empire: "May it 
never once be weak/In the cause of truth and justice in the days that are to come!/Loving liberty, may strangers "neath the Old Flag find a home!" (Scabose igor: 3).

If we peel back the surface of such pro-imperial rhetoric, however, we notice other deeper, and ultimately more persistent, structures of thought. Like many elite communities throughout colonial empires, both the Gold Coast and the Straits Settlements elites took on modes of Victorian, and normatively masculine, self-fashioning in order to be able to act in a colonial public sphere. These involved a series of disciplinary practices, in which manliness - and thus, by extension, civilisation and responsible citizenship - was enacted through a rational restraint on the appetites of the body. Martin Danahay has noted that male Victorian identity was modelled on a Weberian Protestant work ethic that stressed "self-discipline, self-denial and hard work" (Danahay 2005: 7). Idealised bourgeois masculinity was also enacted in the dual spheres of the public and the domestic, the respectable inner life of the home fortifying the male protagonist as he strode forth into the external world of work. ${ }^{6}$ Articles in the Straits Chinese Magazine urged respectability upon members of the community and the adoption of suitable domestic roles. An article addressed to "Straits Chinese Fathers," for instance, urged them to cease "a career of dissipation," exchanging the "temporary exhilaration in the caresses of a mistress" for "the deep, constant and abiding devotion of a pure wife, and "the excitement... of the gaming table, or of the opium pipe of the music halls" for "the joys of a united family circle" (Lew I9ога: 50). Such disciplinary practices should also extend to exercise, diet and dress: young men were urged to take up "riding, cycling, tennis, football and boating" (Lew I9orb: I39) to avoid the excesses of "costly garments, dandy shoes or fancy hats," and to avoid the "excitement for the material body" characteristic of the "wealthy gourmand," in which "the Malay sambal, the Indian curry, the European dishes and pâtés and Chinese pork" were "served at one meal, accompanied by the choicest and strongest wines and drinks of all nations" (Lin I900: IIO). Contemporary articles in newspapers in the Gold Coast made similar pleas: "The impenetrable jungle around us is not darker than the dark primeval forest of the human mind uncultured," wrote the reformer Joseph Ephraim Casely Hayford (I9I0: 3). Cultured respectability, other writers noted, was founded on a domesticity that acknowledged separate 'spheres of labour' for men and women (Brew I898: 4).

Such structures of thought, however, did not result in the whole-scale adoption of contemporary English bourgeois social practices. Both the Straits Settlements and Gold Coast elites disputed elements of English social custom. Newspaper articles relished showing how much resident Europeans failed to live respectable or disciplined lives, yet they also made a parallel and more significant argument - that distinctive 
elements of non-European cultural traditions contained the possibility of a modern rationality that might exceed that of Europe, with its Classical and Christian foundations. The Straits Chinese Magazine, for instance, noted that Confucianism concurred with "all the best teaching of the Roman and Greek Stoics, without the excesses which disfigure European stoicism" ('News and Notes' 1899: 70), while another article argued for a return to traditional Chinese costume for women, since it was "unimpeachable from the standpoint of decorum" (Soh 1907: 3). What appears to be happening here is that individual self-fashioning, which under the codes of Victorian masculinity has little cultural specificity, acquires cultural markers. An article in the Straits Chinese Literary Association Recorder expressed this succinctly:

The past fifty years have witnessed the adoption of numerous European methods in the East; but unfortunately the innovation has not always been advantageous. Whereas the Asiatics have been benefited in many ways, they have been taught habits of luxury and intemperance through their contact with Western people. It should be borne in mind that temperance and frugality have been regarded as two of the best traits in Asiatic character. (Tan I9I8: 7)

Such comments do, of course, draw on an elegiac element of colonial discourse, exemplified by the fictional writings of administrators such as Hugh Clifford, that mourn the erosion of indigenous cultures when confronted with modernity. Yet what is surely important here is that the essence of such cultural difference is imagined in terms of 'character,' 'temperance and frugality.'

In the Gold Coast, similar energies were spent exploring the underlying rationalities of Fante and other cultures. One focus of discussion that united community and individual conduct was the question of polygamy. Methodist churches mapped ideas of 'civilisation' and 'progress' onto the domestic, promoting the idealised nuclear family, monogamous marriage, and the figures of the 'frock lady' and 'respectable' man. Many members of the elites, however, resisted, arguing - mostly from an androcentric point of view - that monogamy undermined the stability of traditional society and, due to the difficulty of divorce, promoted social hypocrisy and illicit sexual relations (Newell 2002: 4).

The production of moral communities based upon notions of disciplinary cultural difference was enabled by a continual slippage between political and individual governance, with each serving as a metaphor for the other. In the words of a contemporary in a parallel colonial situation, Mohandas Karamchand Gandhi, "[r]eal home-rule," was "self-rule or selfcontrol" (I997: II8). Indeed, later anti-colonial nationalism took up this story of internal and external struggle, while changing the identity of its 
actors. The old elites were seen by both Nkrumah's Convention People's Party and by Singapore's People's Action Party as weak and compromised by collaboration with colonial power, and were now described in terms of unmanliness and lack of discipline. Nkrumah initially worked with the United Gold Coast Convention and its leaders, who were largely drawn from the Coastal elites, but then dismissed them as "reactionaries, middle class lawyers and merchants" in his quest for identification with the masses (I957: 62). In Nkrumah's autobiography and elsewhere, members of the elites are described as lacking in manliness. After hearing of the coup that deposed him in I966, Nkrumah describes the terror of the ministers who accompanied him, "in striking contrast to the calmness and courage of the 66 other personnel - the security officers and members of my personal secretariat. These were men. Compared with them, the politicians were old women." Significantly, he concentrates predominately on the reaction of his foreign minister, Alex Quaison Sackey, who came from an elite family and had been educated in Cape Coast (Nkrumah I968: II). In Singapore, much of the energy of Lee Kuan Yew, Goh Keng Swee and other political leaders immediately after self-rule in I959, was directed to castigating the "English-educated," who lacked the discipline of the masses. In a I959 speech, Lee referred to English-educated Malayans as "devitalised, almost emasculated, as a result of deculturalisation" (Lee I959), while Goh, in two articles in the People's Action Party's journal Petir in I960, called for their "rectification" as a class (i960a 7; ig6ob 4). As we move to look at the literary production of Gold Coast and Straits Settlements elites, it is germane to remember that while as groups they have been disavowed by nationalist histories, their structures of thought regarding culture, modernity, and morality have perhaps remained more central to a deep structure of such history than we might imagine.

\section{Literature, cultural capital and the moral community}

In both the Gold Coast and the Straits Settlements, elite uses of the literary looked both inwards and outwards. Literary texts might, it was felt, enable the imagining of a modern community and then bind it together through knowledge of shared cultural history. At the same time, the presence of a literature in English would increase the cultural capital of elite communities in a colonial public sphere at a time when the tightening of mechanisms of government threatened to close it down. Armed with this capital, the community might become an actor both within the colony and potentially internationally.

In the Gold Coast, newspaper editorials and articles stressed the importance of a literate reading community. In part this was no doubt simply a question of self-interest, with newspaper editors concerned 
about increasing sales; editorials discouraging the lending of newspapers to friends were frequent, and young men in particular were enjoined to buy their own personal copies of a newspaper and "read it through" ('What's in a Name' I902: 3). Literacy was seen as a means of entering the modern world and participating in a colonial public sphere for both men and women, but articles also emphasised that the passive act of reading should evolve later into a more active engagement in writing. "[F]rom Assinee right down to Togoland," the Gold Coast Aborigines editorialised, "we may have a few, manly, well-bred men who possess the talent of writing off-hand pungent paragraphs expressing with clearness and courage their opinion on any person or performance: for the good of the dear fatherland, we hope these may not hide their talents" ("The Gold Coast Aborigines' 1898: 3). Both the Aborigines and the Gold Coast Leader published articles giving guidelines to potential contributors with regard to both content and form. While most were implicitly addressed to male readers, the Western Echo ran a "Ladies' Column" from its inception, urging women in the colony to send "contributions to this Column... Anything, even in the shape of extracts or notes from whatever papers or Journals you may have read, would always be acceptable" (Cancoainid I885: 2). Several newspapers held competitions for the best letters or other contributions from their readers.

Print for many journalists in the Gold Coast was perceived as a peculiarly modern form of expression, at a time in which, one commentator noted: "The power of the Pen had been... fast superseding that of the voice" ('Journalism' i899: 4). Not all print culture was necessarily literary expression, but the concept of literature, in the sense used by writers in the Gold Coast at that time and in common with contemporary English and European practice, was not confined to fiction or poetry, but also included history, biography, and accounts of travel and ethnography that were expressive of the elites' own unique experience of modernity. Editorials and articles frequently bemoaned the absence of a local literary culture and the ignorance regarding local history and society that its absence fostered, both within the colony and abroad. Works such as John Mensah Sarbah's Fanti Customary Laws (1897) or J.B. Anaman's The Gold Coast Guide (I894) were praised in contrast to the proliferation of writing on the Gold Coast by "Colonists and Travellers" in which "we are maligned, traduced, vilified and disgraced for the simple reason that things are viewed from an impossible stand-point" ("By the Way' I899: 3). Literary self-representation and the construction of a literary tradition, articles repeatedly noted, were a prerequisite for nationhood, with the newspaper itself becoming "the universally-acknowledged "voice of the nations," the weekly or daily history of the world" ('Journalism' I899: 4). Such control over the way in which history and tradition was told was not merely a matter of bourgeois accumulation of cultural capital; it also 
had real consequences in terms of political autonomy. Struggles between the colonial government, the churches, and different elements of elite communities with respect to the introduction of the Marriage Ordinance in I884 and changes to the Gold Coast Native Jurisdiction Ordinance in I9IO often centred on the ability of social actors to put forward the most persuasive interpretations of traditional custom and law, appealing to historical precedent.

One literary form that incorporated community attributes in individual expression was biography.The genre was present in the Gold Coast newspapers in a variety of forms, including obituaries. ${ }^{7}$ The Gold Coast Aborigines commenced, soon after its foundation, a series of biographies in which "there will be given now and then brief sketches of the lives and labours of some of the flowers of this land who have come, done great deeds and noble but whose works have followed them and seem as it were to have been written on water"; the specific object of telling the stories of such lives was to encourage emulation by a younger generation ('Sketches' I898a: 3). The first life chosen was that of Philip Quaque, born in the Gold Coast in I74I, who at fourteen went to study in England, eventually gaining an MA at Oxford and returning to the Gold Coast as missionary: the outward contours of Quaque's life were sketched, but attention was also given in a subsequent article to "the inner man" ('Sketches' I898b: 3). Biographies tended to emphasise the acquisition of a metropolitan higher education, professional qualifications, and honours as cultural capital. An article on William Addo, for instance stressed both his study for the Bar at the Inner Temple in London, but also a love of literature in which books were "his constant companion" ('William Addo' I896: 2). At times, editorial comment made the goals of biographical representation explicit. J.E. Casely Hayford concluded his biographical account of the life of Hendrick Vroom, itself occasioned by Vroom's being awarded a C.M.G., with a stark warning: "It goes without saying that it would be a retrograde move if in the second century of our existence the policy initiated by the Colonial Office and followed by several of our Administrators be now set aside and the system of importing Europeans, as in the early stage of the Colony, to fill up posts that had been occupied by natives, be reintroduced" (Casely Hayford I896: 2). Casely Hayford was prescient: only five years later, governor George Maxwell would halve Vroom's salary as district commissioner on the grounds that he was a "native of the Gold Coast" (Gocking 2005: 47).

Even articles following generic conventions closer to our contemporary understandings of the literary were heavily - and transparently - didactic. "The Sorrowing Mother," published in the Gold Coast Aborigines, for example, presents the current state of the Gold Coast in the guise of a great grandmother whose daughter and grand-daughter have died young, soon after giving birth to a child. Having endured such circumstances 
because "her religion had taught her that such was the cross that she must bear," she realises in a vision that the problem is something that she herself is empowered to solve. She undertakes a domestic house maintenance and cleaning programme with unmistakable parallels to contemporary improvements in municipal hygiene and, as a result, her great grandchild now prospers ('An Allegory' I896: 3).

Literary texts in the Straits Chinese Magazine were similarly concerned with the reclamation of history and the accumulation of cultural capital. The stress on literacy in the Gold Coast newspapers was to an extent replaced with a concern for translation between three written languages: English, written Chinese - a language in which many Chinese members of the elite were not literate - and romanised Malay, reflecting the patois spoken in the Straits Chinese community but also, more crucially, the lingua franca in the colonial entrepot. The first issue of the magazine featured a version of "Annie Laurie" in Malay and several articles over the decade-long publication history of the magazine introduced Malay texts to non-Malay-speaking readers. Chinese literary texts were also translated, and articles appeared targeting those partially literate in Chinese, in which parallel English and Chinese versions of a classical text were given. Much critical energy was devoted to illustrating the fact that literatures in Malay and Chinese had literary canons that equalled that of English. Tan Teck Soon's series of essays on "Some Genuine Chinese Authors," for instance, began by noting the absorption of Chinese in the Straits Settlements in commerce and work, remarking that "we seldom associate any of them with literature or literary achievement of any kind," before proceeding to enlighten readers regarding "some of the best products of the Chinese mind" (Tan I897: 63, 64).

As was the case with their Gold Coast counterparts, the writers in the Straits Chinese also aimed to reclaim history and the means of representation through literature. The fact that Singapore and the other Straits Settlements were migrant societies resulted in less attention being given to local history and a greater concern for parallel Asian experiences of modernity in the Dutch East Indies, the Philippines, Japan, and in particular China. As in the Gold Coast, writers confronted misrepresentation by colonial officials and travellers. One editorial, for instance, attacked the representation of Chinese characters as avaricious and deceitful in the writings of the colonial official Hugh Clifford and indeed implicitly critiqued the rhetorical economy of the "Native States romance" which presented Malays as nature's gentlemen in constant need of British protection from rapacious Chinese capitalism ('Chinaman in Pahang' I898: 38). Unlike the Gold Coast newspapers, the Straits Chinese Magazine did feature many articles by Europeans, such as the colonial official and amateur linguist Richard James Wilkinson, and D.J. Galloway, the founding president of the Singapore Medical Association. However, their presence 
if anything increased the cultural capital of the Straits Chinese writers, who wrote most of the articles, often based on professional expertise. For example, the two founding editors of the magazine, Song Ong Siang and Lim Boon Keng, were university graduates in law and medicine, respectively.

The Straits Chinese Magazine also carried model biographies, commencing a series of accounts of "Some Local Chinese Worthies" with an account of the 'intrepid' Teochew immigrant Seah Eu Chin, who rose to become a member of the Singapore Chamber of Commerce and a Justice of the Peace. In such stories, literature as cultural capital is emphasised in tandem with a narrative of self-making through the accumulation of wealth: Seah's last years, readers are told, "were most happily spent in the cultivation of Chinese literature of which he was by no means a poor scholar" (Lin I899: 84). Unlike the Gold Coast newspapers, the magazine did not serialise a novel or long travelogues, but it did feature a considerable number of short stories during its decade of publication. These, too, were heavily didactic in tone and often concerned to make a specific intervention in a colonial public sphere. Thus the short story "A Victim of Chap-ji-ki" centres on the discovery by a man that his wife has become addicted to gambling. The news drives him mad, but at the narrative's conclusion his brother and friend resolve to form an "Anti-gambling Society" (Lew I898: 72). In "Lost and Found," an employer finds that a trusted Straits Chinese engineer is imprisoned on suspicion of being a member of a secret society: he is taken to the Chinese Protectorate and threatened with deportation until it is established that Singapore is his birthplace. At the conclusion of the narrative, he is found to be innocent despite this treatment: "contrary to the spirit of British justice deprived of my liberty before trial and conviction" and his employer notes with satisfaction that as a Straits Chinese his employee is "a creature with some backbone and stamina in him" (Lew I900: I76). The story exemplifies a concern that was much discussed in the magazine's pages: the precise status of the Straits Chinese as British subjects, and their right to be tried under British, not Chinese, legal jurisdiction. ${ }^{8}$ As in many of the stories, individual discipline becomes a metaphor for the disciplinary mechanism that a modern community needs to enact to ensure its coherence and survival.

\section{Literature's other face}

Up to this point, we have seen how literary texts function as both cultural capital and as disciplinary technologies in the creation of modern communities made up of autonomous individuals, how they place the self and community in history. The production of moral selves and communities is a response to colonial govermentality enacted through racial 
categories. The elites in both the Straits Settlements did not put aside such categories, but they reworked them, alternately trying on a dizzying variety of universal, cosmopolitan, regional and local identities in order to gain purchase within a colonial public sphere. It is undeniable that there were clear historical differences between the Gold Coast and the Straits Settlements, accompanied by marked differences in languages, social practices, and lifeworlds. Yet parallels perhaps also suggest that culture itself has a history - which the modern imagining of a cultural community necessitates a certain placing of a newly-imagined ethnicised self with reference to both past and future.

In this process, literary texts may serve as something more than cultural capital goods or as guides to conduct for the production of modern individuals. For literary texts operate according to a different rationality from historical ones, often achieving their effects through juxtaposition or association rather than transparent representation or causal connection. The work of Russian literary theorist Mikhail Bakhtin on the novel is helpful here. Novelistic texts, Bakhtin argues, are not univocal, but contain "a diversity of social speech types... and a diversity of individual voices, artistically organized" (Bakhtin I98I: 262). The formal qualities of the text - its artistic organisation in Bakhtin's terms - thus allow what Bakhtin terms "heteroglossia" to enter the text of the novel, in which a "multiplicity of social voices" overlap (I98I: 263). A reader of "artistic prose," as opposed to non-fictional or non-narrative reportage is thus confronted with a "socially heteroglot multiplicity" of meaning caused by intersecting languages and the socio-ideological positions which they represent (I98I: 278). The novel, in Bakhtin's terms, orchestrates such diverse voices, bringing them into dialogue, but it does not reduce them to a single voice. Thus the novel - and 'artistic prose' in general - at a formal level resists simple didacticism or transparent allegory, foregrounding contradictions central to the social order from which it emerges.

Bakhtin is useful in considering two of the most complex literary texts produced by the Gold Coast and Straits Settlements elites. The novel Marita: or the Folly of Love was published in instalments in the Western Echo from I886 to I887, and, after the newspaper closed in December I887, continued to be serialised in the Gold Coast Echo in I888, although it appears never to have been finished. Its author "A. Native" may possibly be either J.E. Casely Hayford or John Hutton Brew, but it is likely we will never know the true identity behind the pseudonym. "The Travels of Chang Ching Chong" - the most generically complex of all the stories in the Straits Chinese Magazine - was published in four instalments in I898: the title's adoption of a Chinese name used as a racial insult from the late nineteenth century onwards is the first indication that it is something more than the 'autobiography' it purports to be. While both texts have didactic elements, they are also complex enough to exceed the apparent 
intentions of their authors, revealing, in their layering of different voices, the constitutional contradictions involved in the fashioning of ethnicity in a colonial public sphere.

Marita's plot concerns the struggles of Mr Quaibu, a member of the Gold Coast elites who is initially a churchgoer but not a 'class member' baptised into full membership of the Methodist church. Quaibu and his partner Miss Wissah have lived "as man and wife for more than eight years, enjoying all the blessings of married life" but her growing religiosity causes the "innocent and harmless pleasures that used to amuse her" to be "considered by her as sinful" (2002: 45), and she demands a full church wedding (2002: 4I). The intricacies of the plot concern Wissah's wilfulness after the ceremony and the manner in which she is exploited by a group of 'scholars' - men with primary education - who hold religious gatherings outside of church. The narrative frequently diverges into discussions regarding the nature of marriage between Quaibu, his friends as well as both African and European church officials and a series of embedded stories of the failure and success of other marriages. The didactic function of the text is clear: Fante modernity consists of picking and choosing elements of European modernity - and Christian marriage is not one of them. The Fante people, indeed, are critiqued as "excessively imitative in their nature" (2002: 4I). In striving to advance as a "nation" they have "acquired all the evil but very little of the good qualities of the European" (2002: 42). Yet the refusal of Christian marriage is hardly progressive: it makes an androcentric demand for female submission central to Fante identity. Indeed, in disputing Christian marriage in the colonial public sphere, Marita paradoxically makes use of colonial discourse concerning the unfitness of Africans for modernity. In discoursing on the difference between the "white virago" and the "black scold," Quaibu notes that African women are culturally unable to appreciate the benefits of modern life:

Whilst the white lady has, by the highly civilized society in which she was brought up and moved, wholesome checks to or upon her natural wicked propensities, as in this instance; the black woman could never dream, at all events according to the present state of society, of being so fortunate, the society in which she moves being primitive, consequently she could have no checks upon her waywardness. (2002: II5)

Wissah's illiteracy and consequent vulnerability are repeatedly foregrounded in the narrative, yet at the same time no model of female education or social advancement is proposed. Educated African women, indeed, are portrayed as inverting a necessary social hierarchy. One of the embedded narratives, for instance, explores the fate of a self-made 
man who marries Mrs Allen, a "woman of the first water in the town of Dobblesie [i.e. "double C" - Cape Coast]". Her continued control over property and marital assets results in her husband, in his own words, selling "my virile qualities, and to a woman too who does not scruple to make use of my helplessness in order to trample upon it!” (2002: 105, 109).

At the formal level of the narrative, we can detect some of the stylistic qualities illustrative of Bakhtinian heteroglossia and dialogisation. Marita, as we have noted, contains many staged - and often overly stagey - discussions of issues to do with polygamy and monogamy, which represent the voices of different elements of Gold Coast society: the Church, native 'gentlemen,' 'primary-educated scholars,' and women. Yet the schematic pedagogy of the text is undermined by a further stylistic quality. The novel contains a series of embedded narratives nestled within each other, almost like Russian dolls, to the extent that their relation with the framing narrative of Quaibu and Wissa is lost. These narratives commence with the consciously allegorical story of a man who leaves his homeland and prospers in another country, only to find his closest friend and business partner grows cold towards him under the influence of his new wife, who has been attracted to a new religion that has recently arrived in the country. The result, the man's friend tells him, is that she has become "so proud and unbearably independent of the man who has made her what she is that at times I have even conceived a notion of killing her and myself to end my misery" (2002: 87). After taking advice, he adopts a firm attitude towards her, which results in her submission.

In the first of a number of ambiguities, this embedded narrative is introduced to readers directly by a first-person narrator who may or may not be Quaibu's friend, Bonsoe Penin; we return to the main narrative, only to be guided away into further sub-narratives. The first, which concerns the Allens and their imbalanced marriage in terms of class, immediately gives way to the second, which introduces the aptly named young man Mr Littlemonie and his marriage to the spoilt Miss Peckdore. Finally there is a third story of marital conflict set in England. Stylistically, the narratives differ: the first of the four narratives is Bunyanesque in its use of allegory, for example, while the story featuring Littlemonie is more Dickensian, or perhaps influenced by contemporary melodrama in its setting up of conflict between characters whose names mark them out as representative types. A common response of scholars to both the narrative digressions and stylistic unevenness has been to see them as evidence of a lack of skill on the part of the author. Roger Gocking, for instance, notes the "rambling" nature of the narrative and its frequent "melodramatic excesses" (I999: 90, 9I). A Bakhtinian reading, while not discounting questions of authorial skill, might focus on the way in which such stylistic variance gives a textual embodiment to "the co-existence of 
socio-ideological contradictions" of the society in which the text is written and read.

While the four narratives share a similar structure, their final denouements differ. In the narrative of the old man, the woman eventually surrenders to her husband's authority, significantly, in narrational terms, the encounter between husband and wife occurs in private and readers only see its results in the wife's renewed submissiveness. The narratives of the Allens and the Littlemonies both conclude with a marital breakdown that deprives the man of his masculine self-sufficiency. Mr Allen complains of being forced to "sacrifice my manhood, ... sell my virile qualities" (2002: I09), while Mr Littlemonie also finds that "his virile quality" has "been taken away from him by the woman" who has become his wife. (2002: II2). In the story of marital conflict in England, there is a different outcome, in which the married couples' young child appeals to his mother to acquiesce to a more passive role and, on hearing him, she sheds "tears of contrition" (2002: II5).

In Bakhtinian terms, we might say that two 'languages' are at war with each other: one that seeks to maintain a traditional patriarchal order, and a second that seeks to refashion society in what Carole Pateman has termed a new specifically modern (or fraternal) form (I989: 35). The paradox, as we have seen, is that a vigorous assertion of imagined African patriarchal difference also appears to obviate any possibility of achieving an indigenous or indigenised modernity. There is no possibility of African women becoming 'highly civilised' - and the possibility of her providing a motor for masculine self-development by civilizing the domestic sphere is thus discounted. Marita's author continues by using the analogies of clay and iron vessels with reference to Christian marriage. "Is it not better," the narrator asks, "to be contented with our clay vessel which we can repair when it breaks until by education, trade, or profession and general habits or custom we could mend the iron vessel when it does break?" (2002: II6). Yet such an argument provides no illustration of how such a change might occur; it thus comes dangerously close - although this is clearly not its intention - to reproducing the colonial rhetoric that Africans are not fit subjects for modernity and must remain in perpetual tutelage. The repeated iterations of the same narrative with different actors thus produces not the insight that allegory often brings - its defamiliarisation of the present through analogy - but rather a sense of confinement within immutable structures of thought, in which the tradition of a moralised community is reified.

"The Travels of Chang Ching Chong" is a narrative that, while less lengthy than Marita, also displays a dizzying mixture of generic slippage and narrative recursion. The story is putatively the 'autobiography' of a young Chinese man Ho Yuan, who is taken on board a Spanish ship and transported overseas. He rather implausibly learns Spanish during 
a fifty-day voyage that ends in shipwreck on an island near the Philippines which has "never been visited by civilised man" ('Travels' i898: I5). The protagonist and his Spanish companions establish a model colony called Santa Maria, but he is restless, and leaves the island with several other crew members on a raft. After further adventures, he is captured by cannibals and then rescued by a Chinese pirate who lives among the savages, whom he terms "sycophants", having made futile attempts to civilise them. Despite the pirate's offer of his daughter's hand in marriage, the hero of the story leaves for the nearby port city of Ganiserop, a transparent anagram for Singapore. In Ganiserop, gender hierarchies are reversed: women beat their husbands and the protagonist eventually enters a ladies' club, where he learns to "dress myself in fancy costume, wash my body with rose water, powder my face, trim my hair in approved fashion, learn to dance and sing, and become initiated in the difficult art of pleasing the ladies" (I898: I42). He is rescued by a woman who falls in love with him; they marry, and return to China, committed to living in "equality" and becoming "objects of admiration to the villagers[,] for we still reside in the hamlet of my forefathers" (I898: I44).

As in the case of Marita, a number of languages are present in "The Travels of Chang Ching Chong" and indeed the story's artistic failure may lie in its inability to orchestrate them meaningfully. As with Marita, two key concerns are metaphorically intertwined: the question of cultural tradition and self-governance, and the question of gender relations in modern society. The protagonist's voyage out into the world allegorises the historical experience of European colonialism: he first travels with the Spanish, founding a colony named after one of Columbus's ships and indeed the initial shipwreck is reminiscent of Columbus's loss of the Santa Maria off the coast of Haiti in I492. His second experience of the colonial order of things is one of ruling subject peoples through a scientised from of racism: Chen, the Chinese pirate who rules over the race of 'sycophants' has given up his initial hopes of civilizing the 'black' natives. What menaces the small Chinese community in particular is the spectre of miscegenation: he complains of "the degradation of his companions" who have married "natives," and in particular the presence of "half-castes" who mimic Chinese identity:

"I had often wished" said he "that some natural calamity would blot out these effete descendants of our great nation. The only connection they have with the traditions and customs of our country is the queue." (I898: 86)

While such conscious identification with ethnicity vanishes in Ganiserop - several characters have Chinese names and reference is made to Chinese languages, although Mullio, the protagonist's lover, has 
a non-Chinese name - it is re-asserted at the end of the story in the return to China and "the hamlet of my forefathers" (I898: I44).

A parallel language to the public one of community identification through race is a more private one, that of gender. The gender roles of Chang's parents follow conventional prescriptions and he escapes into the masculine space of the ship and the Spanish colony. Women only return in the person of Chen's daughter, who bears the conventionally feminine Chinese name Kwei-hwa and is described as a personification of Chinese female beauty. The women in Chen's domain have an ambivalent place. The narrator claims that he has "lifted his women folk out of the degraded position they were in our native land," and yet they remain cloistered at home, and are praised for their modesty and their skill in weaving (1898: 87). In Ganiserop Kwei-hwa is unaccountably forgotten by the protagonist and the inverted gender regime there is presented as monstrous - although the nature of its monstrosity suggests that colonial or patriarchal regimes orders may be similarly preposterous. The return to China is marked by Mullio's marriage, childbearing and the adoption of a demeanour within Chen's extended family that might be described as modern yet modest, very much in line with strictures regarding women's education in order to be better wives in accompanying articles in the Straits Chinese Magazine. ${ }^{9}$

The contradiction in "The Travels of Chang Ching Chong" comes not through reiteration, as in Marita, but in a failure of allegory. Discussing Ganiserop, Chang hears that its prosperity is largely the result of the presence of a race of visitors:

Not very long after the white men had established themselves as masters in Ganiserop, there arrived in the harbour a fleet of strange ships, the bows of which carried two painted eyes. The sails also were unlike anything known to the natives. The men were mostly young or middle-aged, but there were a few old men. Of women and children there were none. These men speak a language so strange that they are not understood in their own tongue to this day. They began to exchange commodities and carried on a brisk business. When the fleet left after four months' stay, about twenty men remained to establish a depot for the sale of the rare products of their land. For many years these people came and went; and every time a fleet of ships came they brought with them a new band of adventurers. No one knew how this nation had been able to produce the wares which everybody so much admired. It transpired afterwards that these men came from the wonderful land of Tasugan, where gods walked among men, and mortals possessed the wisdom of the gods. To make my story short, I may say that the Tasuganese in course of time settled very largely in 
the island, and through their influence and industry, the town of Ganiserop is now a model city and is the seat of a very high civilisation. (I898: I39)

The Tasuganese are clearly the Southern Chinese immigrants who settled in Singapore in the nineteenth century and yet the narrative cannot represent them as being Chinese. In part this is no doubt due to a lack of skill - and indeed planning - on the part of a writer who has already used up all his allegorical options, but slippages in literary texts are significant. The Chinese identity that Chang has constructed during his travels: based on being "a disciple of Confucius," following the "sacred doctrines of our sages," and cultivating a sense of racial difference, ancestry and belonging to a homeland, has no place in the lifeworld of the colonial entrepot (I898: 84, 87). The Chinese lifeworld in the Straits Settlements - and indeed Straits Chinese identity - is not based on the disciplinary creation of a moral community, but on the traffic of goods, languages, and cultures. The story responds to colonial critiques of Chinese immorality and obsession with money by producing a perfected, moralised view of Chinese culture that cannot find a place in Ganiserop/Singapore. Chinese culture in Singapore is represented in terms of fullness, luxury, the 'exchange of commodities' and 'rare products,' yet it cannot explicitly be named Chinese and indeed the protagonist can only claim ethnicity by returning to China.

Literary texts do not undo social and ideological contradictions, but in their representation of different languages of community they illustrate the fault-lines of elite self-fashioning, of repeated attempts to manufacture a culturally specific modernity that undercut themselves. The similarities of the experiences of Anglophone elites in two very different parts of the world enables us, as retrospective readers, to historicise the way in which culture has been taken as central to the construction of the modern community. We look back at these literary productions through the experience of more than a century of a particular historical narrative: the rise of anticolonial nationalism, independence, and then the growing challenges to national sovereignty brought by neo-liberalism and its associated renewed migrations of capital and labour in the late twentieth century.

The experiences of Ghana and Singapore in this narrative have been very different. Singapore's economic development has continued in a linear fashion under single party dominance. Ghana's has been interrupted by economic mismanagement and coups, but the country has also recently experienced genuine political competition in a vibrant multi-party democracy and the state has largely avoided the violence that has afflicted much of the rest of West Africa. If Ghana has served as Singapore's other, it, like all others, emerges on examination as surprisingly similar. What may be most interesting in this period of reconfiguration of state sovereignty 
is the emergence of other claims of moral community that challenge or supersede the disciplinary authority claimed by the state and the manner in which their proponents deploy culture to authorise them, in contrast to the claims of citizenship and secularity made by the state.

Both Marita and "The Travels of Chang Ching Chong" conclude with the establishment of a stable, nuclear family divorced from the sphere of economic production. Their uneasy homologies of individual and communal self-rule find temporary resolution here; the family is a rhetorical place that will soon be appropriated by the nation-state and be sacralised as a space of cultural and social reproduction, even as it begins to lose its status as an economic unit. As Singapore and Ghana live, with both uneasiness and some dexterity, with the consequences of the globalisation of capital, we find haunting similarities in claims of moral community made from outside the state, with sexuality now replacing gender as an object of disciplinary attention. ${ }^{10}$

\section{Notes}

I Works providing historical re-assessments of the period include Barr and Trocki's edited volume. Among the many works that incorporate direct testimony and memoir, see Chin (2003), Chin \& Hack (2004) and Poh, Tan and Koh (2010).

2 See, for example, Huang (2008) and Chua (2008a).

3 Inevitably, there are also key differences between the two colonies. Whereas the Gold Coast was historically the site of the export of forced labour through slavery, the Straits Settlements, at a later period, were the sites of the importation of indentured labour from both China and the Indian subcontinent. Such a difference explains the manner in which the enforced migrations of peoples produced under colonialism are configured very differently in present-day Ghanaian and Singaporean historical imaginaries. I owe this suggestion to Ross Forman.

4 For accounts of Singapore history that emphasize the place of colonialism within a much longer historical process, see Kwa (2004a), and Kwa, Tan and Heng (2009).

5 For a discussion of a slightly later period that nonetheless has important conceptual implications, see Chua (2008).

6 See Tosh (2007); Tosh further notes that there were increasing tensions in the domestic ideal in Britain by the end of the Nineteenth Century.

7 For a discussion of the role of biography in Gold Coast Newspapers, see also Kimble (I963): 520-522.

8 See, for example Song (I899): 6I-67.

9 It is tempting to relate the figure of Mullio and the gender regime of Ganiserop to the figure of the New Woman in Britain and the debate surrounding women's changing roles in society. As Sally Ledger has noted, British feminists of the late nineteenth and early centuries had complex relationships to imperialism that spanned both "complicity and resistance" (I997: 63). However, the object of attention here seems not to be colonialism, but rather the preservation of cultural identity in modernity. As Partha Chatterjee notes, the notion of the New Woman in anti-colonial nationalist discourse is moulded into a "specific ideological form" by an emergent nationalist bourgeoisie, with women's status in society now related to the construction of a moral cultural community (I993: I3I). 
IO I owe the connection between current struggles regarding homosexuality in South and East Africa and colonial conflicts regarding polygamy to Neville Hoad. Similar parallels can easily be found in West Africa. Polygamy has had a different valence in Singapore, given its identification as a feudal practice by anti-colonial progressives paralleled by the postcolonial state's acceptance of polygamy in Muslim marriages. Attempts by conservative Anglicans to make homosexuality an object of social contention, however, bear close parallels to the situation in West Africa. 


\title{
6 Social Discourse and Economic Functions: The Singapore Chinese in Japan's Southward Expansion between 1914 and 1941
}

\author{
Huei-Ying Kuo
}

This chapter examines the strategies and effects of the Japanese-Chinese alliances in Singapore as well as their impacts on changing Japanese views of overseas Chinese in the South Seas (present-day Southeast Asia). The literature on Chinese in Singapore in the first half of the twentieth century has emphasised how the British colonial city port developed as the centre of Chinese anti-Japanese nationalism in the region from the I920s to the I930s (Akashi I970; Leong I977, I979; Wang I981; Yong 1987; Heng I988; Yen I989; Ku I994; Horimoto I997). Based on research into Japanese intelligence reports on the South Seas, this chapter, nonetheless, emphasises Singapore's role in shaping Japanese strategies in dealing with the Chinese in the South Seas in the early twentieth century.

The importance of Singapore in the formulation of Japan's strategies during its southward advance rested not only on trade but also on the Chinese responses to the Japanese expansion. The responses varied among the different Chinese sub-ethnic groups. The latter, who were organised along origin and dialect lines, developed into different immigrant and business networks such as the Hokkien, Teochew, Cantonese, Hakka, and Hainanese. In the late Meiji (I868-I9II) and Taishō (I9I2-I926) eras, Japan's main aim was to cultivate 'Japan-China friendship' (Nisshi Shinzen [日支親善]) in dealing with the Chinese in the South Seas. It successfully incorporated the transnational Chinese networks, above all the most influential Hokkien networks in Java and Singapore, into the Japanese state-sponsored programmes centred in Taiwan, then a Japanese colony. This agenda, however, failed after the late I920s, when the Chinese bourgeoisie, especially those from the Hokkien and Teochew circles, began to organise Chinese anti-Japanese nationalist movements. After that, Japan began to work more closely with the non-Chinese merchants, including the Malays and Indian merchants, while framing the Chinese as outsiders and exploiters of the natives in the region. Although some Chinese (especially those from the Cantonese sub-ethnic group) continued to import goods from Japan to Singapore despite the surge of Chinese anti-Japanese nationalism throughout the I930s, Japan viewed these Cantonese merchants as competitors rather than collaborators. On the eve of Japan's territorial expansion into the South Seas in the late 
I930s, Japan coined sophisticated racial discourses to emphasise the essential differences among various Chinese sub-ethnic groups in the South Seas as well as emphasising their distinctiveness from the generic Han Chinese. These discourses, while heavily influenced by Japan's experiences of earlier encounter with various Chinese groups in the region, reflected a Japanese strategy to prevent the formation of a unified Chinese solidarity among the South Seas Chinese with allegiance to the Republic of China. This chapter concludes that the Japanese changing views on the Chinese in the South Seas in general and in Singapore in particular represented not only the influences of German racial science, but also Japan's unconvincing attempts to establish partnership with certain Chinese subethnic groups in the South Seas between the I9Ios and the I930s.

This chapter is organised as follows: the first section points out Japan's contradictory views on the status of the Chinese in the South Seas in the Meiji discourses, characterised by disparaging the Chinese and China on the one hand and praising the economic achievements of the Chinese in the South Seas on the other hand. The second section introduces the Japanese strategy of building up goodwill with the Hokkien merchants in the South Seas through the Taiwan connections between the I9Ios and I920s. The third and fourth parts elaborate how the Chinese bourgeois communities in Singapore - especially those of the Hokkien and Teochew vis-à-vis the Cantonese groups - responded differently to the expanding Japanese power between the late I920s and throughout the I930s. The Hokkien and Teochew elites organised Chinese anti-Japanese movements, while the Cantonese continued to trade Japanese goods. The Japanese empire reacted to both developments as threats to its interests in the South Seas. To prevent the formation of pan-Chinese solidarity transcending the sub-ethnic cleavages, Japan began to emphasise the essential differences among various Chinese sub-ethnic groups. In conclusion, I point out that as a late industrial country and the only non-white imperialist power in the early twentieth century, the Japanese empire did not set up a consistent economic strategy, nor was there a stable racial or civilisation discourse to articulate the relationship between Japan and the Chinese in general and the Chinese in the South Seas in particular. Japan's changing dispositions toward different Chinese sub-ethnic groups in the South Seas were related to the latter's divergent and variable responses to the expansion of the Japanese empire.

\section{The limits of Meiji Japan's Nan'yō Kakyō [南洋華僑] discourses}

Nan'yo [南洋], literally meaning the South Seas, is the Japanese term for the region surrounding the South China Sea. The Japanese post-Meji documents call overseas Chinese in the region Nan' ${ }^{\prime} \bar{o}$ Kakyō [ 華僑], that 
is 'Shina' [支那]: emigrants to the South Seas. To begin with, the use of the term Shina shows the Japanese sense of positional superiority over China and the Chinese. The use of such disparaging terms began in the Meiji period (I868-I9I2). Before then, Japan viewed China as its cultural mentor and designated it as Chūgoku (the Middle Kingdom [中国]). After the Meiji Restoration, Japanese thinkers blamed China's poor leadership for East Asia's subjugation by the Western powers (Tanaka I993). As early as the I870s, "the idea of a distinctive Japanese national identity was intricately linked to imagining differences from people in China" (Sato 1997: 135). Japanese discrimination against China and the Chinese was further justified after the Japanese triumphs in the first Sino-Japanese War (1894-95), the Russo-Japanese War (1905), as well as the formulation of the Anglo-Japanese alliance between I902 and I923. Japan began to adopt the model of the West's conception of the 'white man's burden' and to view its Asian neighbours as its "Oriental others" and the "yellow man's burdens" (Tanaka I993).

In addition, the Japanese 'yellow man's burden' justified their self-proclaimed mission to civilise other Asian peoples, including those in the South Seas (Weiner I995; Young I999: IOO-IOI, IO5; Gotō 2003). Beginning in the late 1870 , Japanese merchants, workers, and prostitutes started to go to the South Seas for work (Yano I975: 32). Japanese Meiji intellectuals such as Shiga Shigetaka [志賀重昂] and Takekoshi Yosaburō [竹越与三郎] viewed this region as an under-civilised area, where rich and as yet uncultivated resources represented economic opportunities for the Japanese (Yano I975: 52-55). The Meiji discourse continued into the early Taishō era (I9I2-I926). At the Tōkyō Taishō Exhibition held between March and July I9I4, in which cultures and artefacts from Korea, Taiwan, and other "colonial" (takushoku) districts including Hokkaido, southern Sakhalin Island, and Manchuria, as well as the South Seas were exhibited to "display the Empire", peoples from the South Seas were introduced as underdeveloped and barbarian natives (Sakai 2007: 67). In August I9I4, immediately after Japan joined World War I under the Anglo-Japanese alliance, Japan took over German territories in the Southern Pacific (i.e. the Marshall Islands, Mariana Islands and the Caroline Islands). These areas, which were later ruled by the Japan's Southern Pacific Mandate, became known as the Inner South Seas (Uchi Nan'yō). In December i9I4, Japanese anthropological studies of Micronesian people in the Inner South Seas concluded that they were "lazy", "sexually loose" and "uncivilized" (Sakano 2005: 356-357). In the words of the contemporary historian Gotō Ken'ichi, "the South Seas region was regarded as an inferior cultural zone, a narrative that allowed Japan to exercise a free hand in ruling the area. The inhabitants were called islanders, a legal term that drew a clear line between them and imperial Japanese subjects" (Gotō 2003: IG). 
However, when the Japanese began to launch its systemic business expansion into the South Seas in the I9IOs, they soon realised that neither the disparaging Shina discourse nor the Japanese claim of 'yellow man's burden' in the South Seas provided a valid basis for understanding the Chinese in the region. ${ }^{2}$ In I9I2, when the Bank of Taiwan opened its first branch office in the South Seas in Singapore, it tried to approach the Chinese in the region. In I9I4 the bank organised a survey tour to investigate trade and the financial system in the South Seas. It discovered the supremacy of the Chinese far-flung wholesaling and retailing networks in the Dutch East Indies, America's Philippines, French IndoChina, Siam as well as British Malaya. The survey also highlighted the importance of Western banks in Singapore for Chinese remittances from the South Seas to China. Among the ten most popular banks for Chinese remittances in Singapore, eight were run by British, German, Dutch or French capital, alongside the Japanese Bank of Taiwan and the local Chinese/Teochew's Sze Hai Tong Bank. And the British Hong Kong and Shanghai Banking Corporation was the most popular one, because of its fine connection with remittance houses in Hong Kong, the other British colony in Asia (Taiwan Ginkō I9I4: II7). In other words, the Japanese encounters with the Chinese in the South Seas showed that the latter were neither inferior Shina nor were they subjugated people in the Western colonies. The Chinese merchants in the South Seas were taking advantage of intra-Asian trade under the British status quo.

How should the Japanese empire deal with the dominance of the Chinese merchants in the South Seas? This became the key issue in the Japanese ad hoc organisation for southward business expansion, the South Sea Association (Nan'yō Kyōkai, referred to as the SSA hereafter). It was founded in January I9I5 in Tōkyō by top politicians such as Uchida Kakichi [内田嘉吉], Chief of the Home Affairs, the Taiwan Office of the Governor-General (Taiwan Sōtokufu) and Den Kenjirō [田健治郎] from the Japanese Diet as well as by an advocate of Pan-Asianism, Inoue Masaji [井上雅二]. ${ }^{3}$ The SSA specialised in collecting commercial intelligence reports for Japanese zaibatsus [economic conglomerates] and in nurturing Japanese retailers in the region. Consistent with what the survey tour organised by the Bank of Taiwan has observed in I9I4, during World War I, Inoue points out that "[b]ecause the Shina people had long migrated to the South Seas, business power of the region was in their hands" (Inoue I9I7: 200).

What was unclear among the leaders of the SSA was the way that Japan, as a late comer in the South Seas trade, should deal with the Chinese dominance of regional trade. Sometimes the same person proposed mutually contradictory views in this regard. For example, in May I9I9, Kimura Masutarō [木村増太郎], then the director of the Singapore Commercial Showcase (an organisation associated with the SSA), identified the 
Chinese merchants in the South Seas as obstacles to Japanese business expansion in the region. According to his suggestion, to secure its newly gained economic influence in the region, Japan should be ready to compete with the returning European powers as well as the long-established Chinese business networks. Because the Chinese merchants had aligned themselves with the European powers, the two challenges to Japanese influence in the South Seas became one (Kimura 1919: 32-38). In the following year, in Kimura's lecture at the SSA's Taiwan Branch, he pointed out the importance of Japan plugging into the Chinese retailing networks. Given the political chaos in China, overseas Chinese merchants in the region did not receive any home country support. Kimura therefore concluded that Japan needed to cooperate with the Chinese in the South Seas; together they would be able to compete with Western interests in the region (Kimura I920: 9-2I).

\section{Chinese trade under the Japanese agenda of 'Japan-China Friendship', 1910s-1920s}

Without a consistent ideology to define the relationship between Japan and the Chinese in the South Seas, Japan tried to use its Taiwan connections to plug into the Chinese business networks in the region. As 80 percent of the Chinese residents in Taiwan had a Hokkien background, a Japanese survey in 1904 could state that "most Taiwanese were Chinese immigrants from the Fujian area; therefore we can use the Fujian customs as means of understanding the customs in Taiwan" (Taiwan Sōtokufu I904: 59). After the opening of the Singapore office in I9I2, the Bank of Taiwan further established three more branches in the South Seas: in Surabaya (I9I5), Samarang (I9I7), and Batavia (I9I8), all located in the Dutch East Indies. Around the same time, following the establishment of the first overseas branch of the SSA in Taiwan in August I9I5, the second overseas branch was set up in Singapore in September I9I8. In the early I920s, two more offices were opened in Surabaya (I92I) and one in Manila (I925) in the Philippines. ${ }^{4}$ Both the Dutch East Indies and the Philippines were regions where most of Chinese came from the Hokkien sub-ethnic group (Table 6.I). The strategy of using the Taiwan connections to plug into the Hokkien networks in the South Seas was framed as part of the project 'Japan-China friendship' using the support of such prominent Chinese elites in the South Seas as Kwik Djoen Eng ([郭春秧] and Guo Chunyang).

Kwik was the most prominent Chinese merchant connected to the Japanese southward agenda. As a China-born, Java-based merchant, Kwik established businesses that spread throughout South China and the South Seas. His Kwik Hoo Tong Trading Society of Samarang handled 
Table 6.1 The distribution of Chinese sub-ethnic groups in Southeast Asia

\begin{tabular}{|c|c|c|c|c|c|c|}
\hline $\begin{array}{l}\text { Chinese } \\
\text { sub-ethnic } \\
\text { groups* }\end{array}$ & Siam & $\begin{array}{l}\text { British } \\
\text { Malaya }\end{array}$ & $\begin{array}{l}\text { Dutch East } \\
\text { Indies }\end{array}$ & $\begin{array}{l}\text { French } \\
\text { Indo-China }\end{array}$ & Philippines & $\begin{array}{l}\text { British } \\
\text { North } \\
\text { Borneo }\end{array}$ \\
\hline Hokkien & $\begin{array}{r}250,000 \\
(10 \%)\end{array}$ & $\begin{array}{r}812,211 \\
(34 \%)\end{array}$ & $\begin{array}{r}825,000 \\
(55 \%)\end{array}$ & $\begin{array}{r}100,000 \\
(20 \%)\end{array}$ & $\begin{array}{r}240,000 \\
(80 \%)\end{array}$ & $\begin{array}{r}498,000 \\
(30 \%)\end{array}$ \\
\hline Cantonese & $\begin{array}{r}250,000 \\
(10 \%)\end{array}$ & $\begin{array}{r}573,326 \\
(24 \%)\end{array}$ & $\begin{array}{r}225,000 \\
(15 \%)\end{array}$ & $\begin{array}{r}250,000 \\
(50 \%)\end{array}$ & $\begin{array}{r}60,000 \\
(20 \%)\end{array}$ & $\begin{array}{r}116,200 \\
(70 \%)\end{array}$ \\
\hline Teochew & $\begin{array}{r}1,500,000 \\
(60 \%)\end{array}$ & $\begin{array}{r}286,663 \\
(12 \%)\end{array}$ & $\begin{array}{r}150,000 \\
(10 \%)\end{array}$ & & - & - \\
\hline Hakka & $\begin{array}{r}200,000 \\
(8 \%)\end{array}$ & $\begin{array}{r}429,994 \\
(18 \%)\end{array}$ & $\begin{array}{r}300,000 \\
(20 \%)\end{array}$ & 150,000 & - & - \\
\hline Hainanese & $\begin{array}{r}250,000 \\
(10 \%)\end{array}$ & $\begin{array}{r}143,331 \\
(6 \%)\end{array}$ & - & (30\%) & - & - \\
\hline Others & $\begin{array}{r}50,000 \\
(2 \%)\end{array}$ & $\begin{array}{r}143,332 \\
(6 \%)\end{array}$ & - & - & - & - \\
\hline Total & $\begin{array}{r}2,500,000 \\
(100 \%)\end{array}$ & $\begin{array}{r}2,388,857 \\
(100 \%)\end{array}$ & $\begin{array}{r}1,500,000 \\
(100 \%)\end{array}$ & $\begin{array}{r}500,000 \\
(100 \%)\end{array}$ & $\begin{array}{r}300,000 \\
(100 \%)\end{array}$ & $\begin{array}{r}166,000 \\
(100 \%)\end{array}$ \\
\hline
\end{tabular}

"Indicated as Chinese 'races' in the original source.

Source: Taiwan Sōtokufu gaiji-bu (1943: 11-14)

sugar trade between South China and the Dutch East Indies, tea trade in Taiwan, and real-estate development in Hong Kong, among other activities. He belonged to the transnational Hokkien networks in the South Seas. His connection with the multiple jurisdictions in the South Seas can be shown by the fact that he simultaneously held Japanese, Dutch and British nationalities. Beginning in I913, he sought funds from the Bank of Taiwan to establish an ad hoc bank for Chinese merchants in the South Seas (Masao I9I9: 6; Guo I9I9a: 4I-44, I9ı9b: 83; Taiwan Ginkō I939: 258-259; Lin Man-houng 200I; Post 2002).

Kwik's request was well received. In I9ı8, the president of the Bank of Taiwan, Yagyū Kazuyoshi [柳生一義], pointed out the importance of establishing a reliable bank for overseas Chinese to use to send remittances back to their home country, especially to the Fujian and Guangdong provinces, where most of them came from (Yonozu Chōhō i9i8: 74-76). The report also listed potential overseas Chinese co-operators, including "the Cantonese capitalist Loke Yew [陸裕], manager of tin mines and cocoa and pineapple plantation as well as... owner of sugar business in Java”, as well as “Fujian tycoons such as Seah Lian Seah [余連成], Seah Pek Seah [余北成], Lee Choon Guan [李俊源], among others” (Yorozu Chōhō I9I8: 75). The two Seah's were brothers. They belonged to one of the most influential Teochew clan in Singapore in the early twentieth century (Xu Jiaozheng I965: Vol. I. A54-56; see also Song I967: 21, 55, 212-219). The Teochew people backed their native place of origin in the 
eastern part of Guangdong, but not Fujian. Given the paramount influence of the Seah family in Singapore, this mistaken analysis suggests that the Japanese lacked understanding of the Chinese communities in the region. Kwiks participation in the SSA helped the Japanese better understand the Chinese in the South Seas. In Kwik's analysis:

Frankly speaking, overseas Chinese in the South Seas today do not really appreciate the Japanese. For example, comparing the Japanese with the Dutch in Dutch settlements, the Japanese with the British in British settlements or the Japanese with the French in French settlements, the [Chinese] feeling toward the Japanese was worse. I think we should seriously consider the fact that this phenomenon is because of what the Europeans throughout the South Seas have done. Extending from economic ties, political relationships (between the Chinese and Europeans) were also operating in a way that was mutually beneficiary. The key rests on the well organization between [European-American colonial] officials and people as well as very fine communication between them. In short, because of the more skilful strategies of the European and American people, the latter were more popular among ordinary Chinese sojourners than the Japanese. This is my humble explanation about why the Japanese way was unfavourable... Japanese way of interacting with Chinese sojourners should better be conducted along the following approach: while calculating the economic progress, Japan must also take care of the moral dimension to cultivate the emotional bondage. After all, to attract the emotional support [of Chinese sojourners to the Japanese], on the one hand we have to make progress on moral dimension, on the other hand, we have to make the cooperation fit the economic interest (Guo I9I9a: 42-43).

Kwik further pointed out that among all of the overseas Chinese in the South Seas, Japan should specifically work with those coming from Fujian province, not only because the "most wealthy merchants in the South Seas came from the Fujian", but also because "they had the most special feeling toward the Japanese" (Guo I9I9a: 43). By this, Kwik referred to the Hokkien-speaking group coming from Fujian's south-eastern coast like himself.

In I9I9, after six years of negotiating with top politicians in Tōkyō, Kwik was able to take part in founding the China and Southern Bank (Kanan Ginkō [華南銀行]), which attempted to serve both the Japanese small and medium-sized enterprises and the Chinese in the South Seas. Kwik was appointed as a supervisor of the bank. Japan also recruited prominent Taiwanese elites to the board of directors of the bank. 
These Taiwanese elites came from the 'big five families', including Lin Hsiung-cheng [林熊徵] from the Lin family at Banqiao in northern Taiwan and Lin Hsien-tang [林獻堂] (Lin Xiantang) from the other notable Lin family at Wufeng in central Taiwan (Masao I9I9: 6; Guo I9ıаa: 4I-44, I9I9b: 83; Taiwan Ginkō 1939: 258-259; Lin Man-houng 200I). These Taiwanese elites sat on the board of directors of the Taiwan branch of the SSA (Nan'yō Kyōkai I9I7: 4). They were also important shareholders and managers of the other Japanese ad hoc business association for southward business expansion, the Southern Godown Company (Nan'yō Sōko, est. I920). The Bank of Taiwan contributed only 2,450 shares, or 5 percent of the total five million yen of the founding capital of the company, the remainder came from forty-three independent investors based in Japan and Taiwan (57 percent), twenty-seven from Java (22 percent), thirty-one from Singapore (9 percent) and twenty-seven from Java (7 percent). Among them, seven leaders from the big five families of Taiwan held I, ০০o shares each. Kwik Djoen Eng's Kwik Hoo Tong Trading Society and its members held 2,000 shares, equivalent to one fifth of the total IO,I50 shares from overseas Chinese capital in Java (Nan'yō Sōko I936: I2-2I).

In addition to the use of Japan's Taiwan connection to connect with dominant Hokkien business networks via Java to Singapore, Japan also used Taiwan as a stepping stone to develop a direct shipping and trading network between Japan and the South Seas, especially Java and Singapore. In I9I2, the Japanese government sponsored the establishment of the South Seas Mail Steamship Company (Nan'yō Yūsen Kaisha). It operated the shipping routes along Kōbe and Moji in Japan, Jilong in north Taiwan, as well as Hong Kong, Singapore, Batavia, Semarang, and Surabaya (Unekawa I927: 3II-3I3). From April I9I6 onwards, the Taiwan Office of the Governor-General mandated and sponsored ocean liners and tramp steamers to connect the waterway between Jilong and Singapore via Java. Singapore became the centre of the Japanese triangular Java-Singapore-Calcutta shipping route (Unekawa I927: 386; 647-649).

The progress of Japan-Singapore trade was significant. Before I9I4, only five Japanese companies were registered in Singapore. Between I9I 6 and I9I8, about twenty Japanese trading companies and individual merchants opened offices there. These included leading zaibatsus such as the Mitsui Bussan Kaisha, Mitsubishi Shōii Kaisha, and Suzuki Shō ten (Shimizu and Hirakawa I999: 68). To facilitate the Japanese trade in Singapore, in I9I8, the Japanese Department of Commerce and Industry in Tōkyō sponsored the establishment of the first Japanese merchandise showcase in the South Seas in Singapore, the Singapore Commercial Showcase. Affiliating with the SSA, it was an exhibition, education, and reception centre for Japanese merchants and their business partners in the South Seas. The centre also recruited ten to thirty students or interns 
from high-school graduates in Japan and provided them with courses on the business skills needed in the South Seas, such as fluency in the English, Dutch, and Malay languages as well as economics, law, and finance. The second overseas office of the SSA was opened in Singapore in February i919 (Nan’yō Kyōkai 1918: 67-73; Kimura I921: 14-22). By then, the Singapore Japanese Business Association listed 50 founding members. All were Japanese banks, shipping or trading firms (Nan'yō Kyōkai I9I9: 7I).

When the European powers returned to the South Seas after the end of World War I, Japan tried to retain its influence in the region. One strategy was to further develop the Japan-Taiwan-Singapore shipping route. In addition to the South Seas Mail Steamship Company, which engaged in Japanese shipping to the South Seas from I9I2 onwards, the Japan Mail Steamship Company (Nihon Yūsen Kaisha) and the Ōsaka Mercantile Steamship Company (Ōsaka Shōsen Kaisha) also managed their own regular shipping lines in the region after 19I9. Among these shipping lines, the monthly South Seas line of the Ōsaka Mercantile Steamship Company was mandated by the Japanese colonial office in Taiwan (Unekawa I927: 533). In April I9I9, the Ōsaka Mercantile Steamship Company established a direct shipping line between Jilong and Singapore (Unekawa I927: 65I). Overall tramp tonnages from Japan to the South Seas increased from 52,50I in I9I6 to I43,734 in I9I9..$^{5}$

An SSA leader, also a representative of the House of Peers, Baron Tōgō An [東郷安], stated that "the colonisation of Taiwan was the first step of our Empire's southward advance. Taiwan is located in the subtropical area that is separated from the Philippines in the South Seas by only a narrow strip of water. The twenty years of experience of Japanese development in Taiwan could provide a valuable asset for us to explore South Seas resources" (Tōgō I9I9: II2). The Office of the Governor-General, Taiwan, played a more important role than the Japanese Ministry of Foreign Affairs in setting up the SSA's operations during its first twenty years (Kawarabayashi 2007).The Japanese government became aware of the importance of Taiwan in Japan's southward advances in the I920s, when SSA-associated leaders in Taiwan were promoted to higher ranks in the colonial government in Taiwan. One of the SSA's founding members, Den, became the governor of Taiwan between I9I9 and I923; Den was succeeded by another SSA leader Uchida, who became governor between I923 and I924. In addition, the Japanese Treasury offered funds to help the China and the Southern Bank reopen after it closed for three weeks in April 1927.6

The success of the Japanese attempt to cultivate 'Japan-China friendship' in the South Seas prior to I928 can also be verified by the fact that, between I9I9 and I928, although sporadic anti-Japanese riots had flared up in Singapore, the Hokkien elites in Singapore remained indifferent 
(Kenley 2003: 52-53; Kuo 2006a). In addition, in September I923, when an earthquake destroyed Tōkyō, top Hokkien leaders - including the rubber tycoon Tan Kah Kee [陳嘉庚], the comprador of the Hong Kong and Shanghai Bank See Tiong Wah [薛中華], as well as the leader of the Ho Hong Group of Companies Lim Peng Siang [林秉祥] - organised the I923 Singapore Chinese Relief Fund for Earthquake Victims in Japan (NYSP: 28 Sept., I923; Tan Keong Choon I98I: Reel I3, p. II9). The beneficence went both ways. In the following year, the Singapore Japanese Association organised a relief fund to assist victims of China's floods (NYSP: II, Sep., I924).

Furthermore, the Hokkien-based Home Salvation Campaign of the Fujian Sojourners in the South Seas (the Nanyang Minqiao Jiuxiang Hui or $\mathrm{NMJH}$ ) also became a platform for potential economic and political cooperation between Taiwan-associated Hokkien and British-associated Hokkien in the South Seas, including Singapore. The NMJH was founded by the Manila-based Hokkien elite Li Qingquan [李清泉] in March I926. About 28 Hokkien merchants from the Philippines, Java, Malaya, and Shanghai participated in the founding meeting. Among them were merchants associated with Kwik's Semarang Tea Agent Association, which imported tea from Taiwan (NYSP: 20 Aug., I926; Chen Tian-lai I938: 29, 37; Kawarabayashi 2000: I07-II3). The association also recruited the Singapore-based Hokkien elite Lim Boon Keng [林文慶]. Lim was a notable 'King's Chinese', who became the first Chinese recipient of the Queen's Scholarship in I887 and received the Order of the British Empire for his various services to the Straits Settlements (Song I967: 235-238). Addressing the importance of the Hokkien's cooperation, Lim stated that "today, only overseas Chinese can save the Fujian province" (Nanyang minqiao jiuxianghui linshi daibiao dahui I926: 22). To save Fujian province, the NMJH's top priority was to found the Fujian Railway Company. Its goal was to reactivate the railway project in southern Fujian, which had been initiated in 1905 but was soon thereafter aborted due to a shortage of funds. In the IgIos, Japan expressed an interest in participating in the southern Fujian railway project, but the Chinese government did not approve the Japanese proposal (Mi ed. 2002: 225-229). In the early I920s, Lim Boon Keng became one of the eleven members of the preparatory committee for the inauguration of the railway agenda, together with the project's primary planner Oei Ik Tjoe [黃奕住] (NYSP: 28 July, I924; I9 Jan. I925; 29-30 Nov. I925). It is worth noting that Oei, the China-born, Java-based merchant who founded a bank in Shanghai in the I920s, became the largest shareholder of the Japanese Southern Godown Company among its investors based in China. ${ }^{7}$ Although the railway project remained on hold throughout the I920s and I930s, the $\mathrm{NMJH}$ connected the Japanese-associated and the British-associated Hokkien elites into the same network. 


\section{The rise of Chinese Anti-Japanese nationalism in the Singapore Chinese business communities}

Despite the increasing amicability between Japanese interests and the Hokkien elite in the South Seas in the I9IOs and I920s, the Jinan Incident on 3 May, I928 interrupted this improving Chinese-Japanese partnership. In response to clashes between the Japanese Kwantung Army and the Chinese Nationalist Army in Jinan in Shandong province, the Hokkien leader Tan Kah Kee organised the first and foremost Chinese nationalist fundraising campaign in Singapore, the Shandong Relief Fund. From then on, Tan Kah Kee became one of the most influential Chinese anti-Japanese nationalist leaders in Singapore (Yong 1987). Prior to the Jinan Incident, Tan had been friends with Kwik Djoen Eng and the influential Taiwanese Hokkien Lin Hsien-tang. When Lin visited Singapore to supervise the businesses of the Southern Godown Company in May 1927, he was received by both Kwik and Tan (Lin Xiantang 2000, Vol. I: I2I). Tan also admitted that, before the Jinan Incident, he used glass bottles from Japan to pack his medical products (NYSP: 20 June, I928).

The surging Chinese anti-Japanese nationalism jeopardised the Japanese Taiwan-Singapore connections. Taiwanese concerns were considered to be indistinguishable from Japanese interests. A local Chinese newspaper identified the establishment of the Singapore Taiwan Association (founded in I9I4) as the first Japanese association in Singapore (NYSP: 9 May, I924). Beginning in May I928 and throughout the I930s, whenever anti-Japanese sentiments were stirred up, Taiwanese merchandise suffered; they were labelled 'inferior goods' (liehuo). Chinese agents involved in trading Taiwanese or Japanese goods had either to stop doing business temporarily or to change their trading partners permanently (Kuo 2006b).

This Chinese boycott of Taiwanese goods, especially Taiwanese tea, was not only an expression of patriotic fervour; it was also related to business competition. Exports of Taiwanese tea to the South Seas, which grew rapidly in the early I920s, challenged the Chinese tea trade. Chinese tea agents in Singapore tended to substitute Chinese tea with tea from Taiwan. But after the I928 Jinan Incident, many Hokkien tea merchants in Singapore declared they would no longer import tea from Taiwan, but from Fujian only. For example, the Lim Ho Thye Tea Chop (Lin Hetai cha zhuang) posted a notice in a Chinese newspaper, which read as follows:

Previously we have ordered tea from Taiwan. Now these inferior stocks [sic] are gone, but we decided not to abandon our previous trademark as it has been used for years. We will keep the same Thye Chuan Yellow bottle-gourd trademark, but the content will 
be replaced by tea imported from our Amoy head office. These tea stocks were all collected from [China's] Wuyi Mountains (NYSP: 28 July, I928).

The owner of the store, Lim Pun Tao [林本道], became the first chairperson of the Singapore Tea Merchants Association. ${ }^{8}$ One of its aims was to boycott Taiwanese tea and to promote Chinese tea (NYSP: 26 June, 28 July, 27 Sept., and 5 Oct., I928; Singapore Tea Importer-Exporter Association 1928). Another leader of the association was Lim Keng Lian [林慶年] (1893-1968), owner of the Chop Lim Kim Thye. He became an active Chinese nationalist leader in the I930s. ${ }^{9}$

The Taiwanese tea trade slumped sharply thereafter. In I925, the total value of Baozhong tea (a semi-fermented tea) imported from Taiwan to British Malaya was 487,884 Japanese yen. This was reduced to Io6,076 yen in 1928 and 22,990 yen in I929, and represented only 4.7 percent of its 1925 value. Although the trade recovered after 1933, its value in I935 was 267,496 yen, barely more than 50 percent of its I925 value (Taiwan Sōtokufu shokusan-kyoku tokusan-ka I935: 254-255). The amount of Taiwanese tea carried by overseas Chinese merchants also declined. In I929, overseas Chinese merchants were responsible for selling I7 percent of Taiwanese Baozhong tea, the Taiwanese contributed 72.6 percent of the trade, and non-Chinese merchants, including the Japanese and other ethnic groups, accounted for the remainder at 3.7 percent and 6.7 percent of the trade, respectively. But in I934, the amount handled by overseas Chinese merchants fell to I4.2 percent, the trade handled by the Taiwanese slumped to only 58.5 percent, and the Japanese trade in Taiwanese Baozhong tea rose to II.6 percent, while the share of other ethnic groups also jumped to I5.7 percent (compiled from Taiwan Sōtokufu shokusan-kyoku tokusan-ka I935: 303). Against this backdrop, the closure of the Singapore Taiwan Association marked the failure of the Japanese attempt at using Taiwan connections to plug into the Hokkien business networks in the South Seas (Straits Settlement I934: II27).

Concomitant with the surging Chinese anti-Japanese nationalism after the late I920s and throughout the I930s, "buy Chinese" movements appealed to Chinese merchants in Singapore to import merchandise from China to substitute Japanese goods. Some Chinese stores, especially those located on Circular Road and South Bridge Road, emphasised that they sold only Chinese textiles (Shingapōru shōhin chinretsu-sho I933a: 47). And shoes imported from Hong Kong and South China were sold by those "Cantonese, Hainanese, and Teochew merchants who carried cheap products" (Shingapōru shōhin chinretsu-sho I932a: 24, I932b: 28). Thanks to the implementation of British preferential tariffs, these "made in Hong Kong" products could be sold in Singapore and other British 
territories at lower prices. ${ }^{10}$ But favourable price was not the only reason that the Chinese goods were competitive. Cotton blankets, knitwear, underwear, cotton handkerchiefs, and cotton towels from Hong Kong also appealed to Chinese consumers because of their special designs and colours (Shingapōru shōhin chinretsu-sho I933a: 32-33, I933b: 27, 38, I933d: I03). The inflow of Chinese industrial goods from Hong Kong therefore intensified the business competition between Chinese and Japanese goods in Singapore.

It is, however, noteworthy that despite all the anti-Japanese nationalist boycotts, overall exports from Japan to Singapore continued to grow. During the period between 1928 and I937, Japan's exports to the Straits Settlements (including Singapore, Penang, and Malacca) rose 3.3 times (compiled from Nihon Naikaku Tōkei-kyoku, I996). British intelligence reports pointed out that not all Chinese unanimously supported the antiJapanese boycotts: in the wave of anti-Japanese boycotts beginning in January 1932, major distributors of piece goods on Circular Road (most of them specialised in the trade of British textiles) stopped carrying any Japanese goods for almost an entire year. But outside Circular Road, Chinese, Arabian and Indian merchants continued to trade Japanese textiles (Kuo 2006a). SSA newsletters further revealed how Chinese trading in Japanese goods stubbornly continued, despite increasing anti-Japanese feeling. One survey showed that, from I June to I8 June I934, among the 58 companies that ordered Japanese cotton textiles to Singapore, 15 Chinese agents handled 33.3 percent of the trade $(3,748,475$ yards out of total Io,336,24I yards), surpassing the Indian, Japanese and other European agents in the same line of business. II The other one-year survey between I October I930 and 30 September I93I showed that near 99\% of Japanese rubber shoes, such as rubber-soled canvas shoes and rubber boots exported from Kōbe, Ōsaka and Moji would eventually enter the markets in Singapore (Shingapōru shōhin chinretsu-sho I932a: 26). In addition, nearly half of Japan's rubbersoled shoes imported to Singapore were handled by Chinese dealers. Some of them ordered the shoes from Japanese import-export agents or manufacturers in Japan, while others built up long-term business ties with their co-Chinese counterparts in Japan. The latter, eleven Chinese merchants on High Street (Table 6.2), contributed to nearly 30 percent of the total sales of Japanese rubber-soled canvas shoes as well as other rubber products shipped to Singapore through commission trade.

Another of SSA's report reveals that among the High Street Chinese companies, only one was run by a Hakka, while the rest were all run by Cantonese (Nan'yō Kyökai chosa-ka I940: 127). All 'High Street' Cantonese textile merchants were active in the commission trade - usually in the form of deferred payment for 30 to 60 days - along the Köbe-Singapore networks (Shingapōru shōhin chinretsu-sho I933c: 28-29). It has been estimated that in the early I930s, about 53 percent of 
Table 6.2 Importers and wholesalers of Japanese shoes in Singapore (survey period: 1 Oct. 1930-30 Sept. 1931)

\begin{tabular}{llc}
\hline Import channels & $\begin{array}{l}\text { Number and ethnic } \\
\text { origin of trade agents }\end{array}$ & $\begin{array}{c}\text { \% of trade amount } \\
\text { (based on quantity) }\end{array}$ \\
\hline Import through exports agents and & 7 Japanese merchants & 4.4 \\
manufactures in Japan & 10 Chinese merchants & 20.5 \\
& Indian merchants & 0.4 \\
Import through its own head office and & 3 Japanese companies* & 44 \\
associated manufactures in Japan & & 30.6 \\
Import through agents in Kōbe & 11 Chinese agents & \\
or Ōsaka & & \\
\hline
\end{tabular}

* The three companies were Mitsui Company, Mitsubishi Company, and Nichinan Bōeki Kabushiki Kaisha. Among them, Mitsui Company controlled 60\% of this portion of trade.

** All eleven Chinese agents in this category were located on High Street.

Source: Shingapōru shōhin chinretsu-sho 1932a: 26-28

Japanese goods (worth 80,000,000 yen) exported from Köbe to central and southern China as well as to the South Seas were handled by Chinese merchants. By July 1937, 48 of the 98 Chinese stores in Köbe were run by people from Guangdong province, $\mathrm{I} 8$ of them from Fujian province and the other 32 from the Lower Yangzi area (Chūka Kaikan 2000: I87). Given the fact that "the Cantonese only traded closely with the Cantonese, the Hokkien only trusted those who were also Hokkien" (Nan'yō Kyōkai chosa-ka 1940: 127), it is reasonable to assume that more than half of the Japanese exports from Kōbe to Singapore were handled by the Chinese merchants, most of them Cantonese merchants on High Street.

To summarise, while Hokkien elites became leaders of Chinese antiJapanese nationalism after the late I920s, thus ending Japan's earlier attempts to cultivate the 'Japan-China friendship' via the Hokkien networks between Taiwan and the South Seas, Cantonese merchants in the Kōbe-Singapore networks picked up the slack in the I930s, coming to constitute an important channel for about one third of growing Japanese export to the region. What follows will explain why this development did not lead to a Japan-Cantonese alliance in the same way that earlier Hokkien trade facilitated a Japanese-Hokkien partnership.

\section{Cantonese merchants as competitors to Japan's southward advance}

From the perspective of the Japanese empire, the Cantonese monopoly of Japanese trade in the South Seas was as disappointing as the Hokkien's support of anti-Japanese Chinese nationalism. In I932, an internal report of the China and Southern Bank concluded that Japanese southward 
economic expansion had failed. Twenty years after Japanese official sponsorship of southward business expansion, "commerce, industry, and maritime navigation in the South Seas were still under the control of overseas Chinese" (Kanan Ginkō I932: 6).

The Japanese disappointment can be explained by the following factors. First, the Chinese merchants of Japanese goods, the Cantonese Kōbe-Singapore network in particular, were not exclusive channels for the sales of Japanese goods. In the Japanese textile trade for instance, throughout the I930s, whenever there were Chinese anti-Japanese boycotts, the Chinese merchants ordering Japanese goods would temporarily give up the trade - either to shift to selling Chinese products or to deny that the merchandise that they had ordered from Japan was Japanese when it arrived (Shingapōru Sangyōkan I94I: 6r). Among the Chinese/Cantonese companies that shifted from carrying Japanese goods to competing merchandise from China/Hong Kong and England were the Cantonese 'High Street' agents Ng Hong Hing Company and Kwong Wah Long. The latter had dominated the import trade in Japanese cotton blankets to Singapore by I930 (Shingapōru shōhin chinretsu-sho I93I: 5I; Table 6.3).

In addition, unlike the Taiwanese elites who were recruited into Japanese ad-hoc organisations engaged in a southward advance, such as the SSA, the China and the South Seas Bank, and the Southern Godown Company, the Cantonese merchants carrying Japanese goods were not included in any Japanese business associations in Singapore. In the Japanese rayon cloth trade, the Japanese had the Japanese Textiles Importers Association of Malaya, the Chinese/Cantonese established the Chinese Importers and Exporters Association (Lianyi Gongsuo in Chinese), the Indians had the Siudi Merchants Association, and the Europeans had the Singapore Importers Association (Shingapōru shōhin chinretsu-sho I936: 30). These groups operated as separate entities that competed with one another.

Last but not least, the development of Cantonese middleman trade in the South Seas did not help the expansion of Japanese zaibatsu such as Mitsubishi Company and Mitsui Company. Although some agents of the Kōbe-Singapore trade, mostly Cantonese, would use Japanese banks, these merchants were not exclusive clients of Japanese state-sponsored banking, shipping, insurance and trade enterprises (Shingapōru shōhin chinretsu-sho 1936: 31). As the Japanese initial goal of southward business advance in the I9IOs was to establish a direct connection between manufactures in Japan and overseas exporters in the South Seas, the control over the export of Japanese goods by the Chinese/Cantonese merchants in Kōbe was viewed as an obstacle to Japan's agenda (Shimizu and Hirakawa 1999: 68-73). Nonetheless, in the early I930s, the Japanese direct export handled near 30 percent of the textile trade (Nan’yō Kyōkai I934: 96). And, among the Chinese merchants importing rubbers shoes from Japan to Singapore, the eleven Cantonese merchants 
Table 6.3 Chinese textile wholesalers and retailers dealing in Japanese cotton cloth, sarong and rayon in Singapore, 1933

\begin{tabular}{|c|c|}
\hline Company" & Address \\
\hline Kyen Ho Loong \& Co. & 68 High Street \\
\hline Him Woo \& Co. & 66 High Street \\
\hline Wing Hing Loong \& Co."* & 70 High Street \\
\hline Yue Tai \& Co. & 72 High Street \\
\hline Woo Song Loong \& Co. & 76 High Street \\
\hline Chong Futt (chop) & 86 High Street \\
\hline Loe Sang Yuen Sing Kee & 81 High Street \\
\hline Chop Yick & 79 High Street \\
\hline Kwong Wha Loong** & 75 High Street \\
\hline Ng Hong Hing \& Co."* & 73 High Street \\
\hline Kwong On (chop) & 26-28 South Bridge Road \\
\hline Sam Yik \& Co. & 20 South Bridge Road \\
\hline Kwong Fook Tai & 231 South Bridge Road \\
\hline 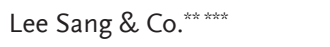 & 241 South Bridge Road \\
\hline Chop Kwong Yick & 234 South Bridge Road \\
\hline Nam Sang (chop) ${ }^{* \ldots * *}$ & 232 South Bridge Road \\
\hline Choon Fat & 230 South Bridge Road \\
\hline Wing On & 32 South Bridge Road \\
\hline Chop Nam Seng & 16 South Bridge Road \\
\hline Wing Wah Cheong & 34 South Bridge Road \\
\hline San Lee Guan & 24 South Bridge Road \\
\hline Ming Kee \& Co. & 219 Beach Road \\
\hline Teck Sang Hing (chop) & 116 Rocher Road \\
\hline Thakordas Chhotalal \& Co. & 26 Kandahar Street \\
\hline Masiamull Nagindas & 578 North Bridge Road \\
\hline Mehamad Kasin \& Co. & 12-13 Boat Quay \\
\hline Hasannasan \& Co. & 20-22 Chulia Street \\
\hline G. A. M. Gabriel \& Co. & 24-26 Chulia Street \\
\hline Kimatolai \& Co. & High Street \\
\hline Chop Yick Tai & 467 North Bridge Road \\
\hline
\end{tabular}

"There is no record of the Chinese names of these companies. All were reported to substitute the sales of Japanese with Chinese products in 1932 when Chinese anti-Japanese boycotts peaked.

** Companies also carrying British rayon in a survey in 1933.

*** Companies also carrying Chinese cotton towels in 1933.

Sources: Shingapōru shōhin chinretsu-sho 1933a: 46-48, 1993d: 101-104, 1933e: 105-108

on High Street who controlled 30 percent of the trade did so without forming direct connections with either Japanese exporters or manufactures (Table 6.2). Furthermore, in the late I930s, when Chinese anti-Japanese boycotts included violence against the Chinese merchants selling 
Japanese goods, Chinese wholesalers of Japanese goods would try to use Indian merchants to retail these products in Singapore (Nan'yō Kyōkai I939: I6). The original document refers to Chinese not Cantonese wholesalers, but given that these importers neither imported goods from Japanese factories nor used Japanese export agents, it is reasonable to assume that this was exclusively Cantonese commission trade. The salience of this Cantonese trading network accounts for the Japanese response. The Singapore branch of the SSA viewed the Cantonese-Indian cooperation as the Cantonese attempt to monopolise the supply of Japanese goods in Singapore. The office therefore decided to introduce exporters from Japan to the Indian retailers in Singapore, in an attempt to marginalise the Cantonese wholesalers (Nan'yō Kyōkai i939: i6; see also Post i995; Shimizu and Hirakawa I999).

\section{After 'Japan-China Friendship': South Seas Chinese as different racial groups}

Competition with the Cantonese Japan-Singapore trading network aroused Japanese concern about the domination of the Chinese middleman trade in the South Seas. In the I930s, Japan began to identify the exploitative nature of the dominance of the Chinese in the South Seas. In I930, the director of the Singapore Commercial Showcase, Masubuchi Sahei [増淵佐平], emphasised the exploitative relationship between the Chinese merchants and the native Malays in agrarian communities in the Malay Peninsula. He also pointed out the importance of developing Japanese small enterprises in the region to replace the Chinese exploiters (Masubuchi I930: 32-33). In 1932, a report by the China and Southern Bank suggested that the success of the Chinese middleman trade in British Malaya was based on the Chinese control over the livelihood of the local Malay communities. For example, in the trade of marine goods, Chinese merchants controlled loans and the supply of groceries for entire fishermen's villages. Local fishermen, therefore, simply had no alternative but to sell their products to the Chinese, regardless of price (Kanan Ginkō I932: 3-II). Furthermore, Watanabe Kaoru's [渡辺薰] article, published in the newsletter of the SSA in April I934, used parallels with anti-Semitism to criticise the Chinese middlemen merchants in the South Seas. According to this view, Chinese traders controlled the trade in commodities. Instead of trying to increase the competitiveness of Chinese products in the markets, the Chinese in the South Seas organised anti-Japanese boycotts to devastate the Japanese trade in the region. Together with rising protectionism in European and American markets, Japan should treat the Chinese in the South Seas as challengers to the Japanese economic growth (Watanabe i934). 
Wanatabe's statement marked a departure from Japan's previous agenda that had sought cooperation with the Chinese merchants in the South Seas. After the middle of the I930s, the Office of the GovernorGeneral in Taiwan also reconfigured Taiwan's role in Japan's imperial advance. In I936, the Taiwan Colonisation Company Ltd. (Takushoku Kabushiki Kaisha) was established, with half of the funds coming from the Taiwanese colonial government and the other half contributed by leading zaibatsus, banks and individual investors. Lin Hsiung-cheng and other Taiwanese/Hokkien elite, who had been involved in Japan's earlier southward expansion, also invested in the state-run company. But the rationale for the Taiwan Colonisation Company was not to create a bridge to Japan's connections with the Chinese in the South Seas. It was to use the resources of the region for Japan's military, especially naval, expansion (Gotō I995: 85-88; Wang Shiqing 2008: 2-3). Furthermore, from January I939, the SSA became a legally incorporated foundation, directly supervised by Japan's Ministry of Foreign Affairs and Ministry of Colonial Affairs. One of its aims was 'to clarify the misunderstandings with the South Seas Chinese [about Japan] and to introduce them to the ideas of coexistence and co-prosperity' (Kawarabayashi 2007: I2I). Accordingly, small and medium-sized enterprises as well as the Chinese bourgeoisie in Western colonies in the South Seas were no longer seen as instrumental to the Japanese agenda of southward expansion after the middle of the ig3os.

The Japanese problematisation of the Chinese domination in the South Seas and their emphasis on the Japanese state-led agendas of co-prosperity resonate with the formulation of Japan-led Pan-Asianism (Meishuron Pan-Asianism). Departing from earlier advocates of cultural links between Asian peoples, especially those between the Chinese and the Japanese from the Igoos to the I920s, the nascent Japan-led PanAsianists in the I930s emphasised Japan's responsibility for freeing other Asian peoples from the "immaterial, historical deadlock of Eurocentricism" (Hotta 2007: I68). In other words, they legitimised Japan's expansion into other parts of Asia in order to rescue peoples subjugated by Western colonial rule.

Alongside these changes, Japan also adjusted its discourse on the Chinese in the South Seas from the I93os onwards. The Chinese in the region were no longer regarded as an undifferentiated part of the Shina people, but were viewed as different 'races', divided by origin and dialect ties. This classification itself is nothing new. Colonial censuses in British Malaya, Dutch East Indies, and Japanese Taiwan all differentiated the Chinese by their dialects. What distinguished the Japanese understanding of overseas Chinese from the other sub-ethnic classifications from the I930s onwards was the association between each dialect group and essential racial traits. Under the influences of Japan's experiences of 
forming amicable partnership with the Hokkien in the I9Ios and I920s as well as its intensifying competition with the Cantonese after the late I920s, the discourses developed in the I930s emphasise the differences between the Chinese from Fujian and Guangdong provinces and the generic Han Chinese.

In I93I, a Japanese bureaucrat based in Singapore, Kobayashi Shinsaku [小林新作], provided detailed descriptions of the economic status as well as the ethnic characteristics of each of the major Chinese sub-ethnic groups with mutually unintelligible dialects: the Hokkien "mostly engage in trade, their key personality trait is endurance" (Kobayashi I93I: 90-9I). The Cantonese are "quick and smart" and, due to their greater exposure to an overseas atmosphere, they are more educated (Kobayashi I93I: 92). Kobayashi also pointed out the difference between those born in China (China-born Chinese) and their foreign-born counterparts in the South Seas. These new immigrants from China, because their "biological characteristics are not yet affected by the tropical hot summer", became more diligent than their foreignborn counterparts (Kobayashi I931: 88-89). These observations, on the one hand, reflected the shift in the Japanese anthropological paradigm from cultural to physio-anthropology after the late I920s (Sakano 2005: 404-406); on the other hand, they also reflected Kobayashi's concern about soaring Chinese nationalistic feelings among the China-born Chinese, who, unlike their lukewarm local-born counterparts, became enthusiastic about boycotting Japanese goods in Singapore after the I928 Jinan Incident (Kobayashi I93I: 295-342).

After the Jinana Incident and throughout the I930s, a series of Chinese anti-Japanese boycotts in the South Seas in general and in Singapore in particular marked the limits to Japan's earlier attempts to seek 'JapanChina friendship' by aligning with the Hokkien elites via Taiwan. Through its earlier efforts Japan had nonetheless accumulated valuable insights into the Chinese in the region. In I938, the ex-Japanese officer from Taiwan, Ide Kiwata [井出季和太], coined the term Fujian people (minzoku). ${ }^{\mathrm{I2}}$ Ide emphasised the fact that the Fujian people, as well as the Chinese sojourners who originated from this province, were different from the Han Chinese. Although Fujian is known as an important destination for several waves of southward migration by the Han Chinese from the Yellow River basin (which was identified as the heartland of the Han Chinese civilisation) from the fourth century onward, long periods of intermarriage between the northern Han immigrants and the indigenous people in Fujian had created a unique coastal people (minzoku) (Ide I938: 25-36). Overall, his approach established a framework within which Japan could deal flexibly with different Chinese groups.

Ide was not alone in this respect. In the same year, a report by the Taiwan Greater Asiatic Association (Taiwan Dai-Ajia Kyōkai) pointed out 
that "the Hokkien in Fujian and the Cantonese in Guangdong have very different ethnicities. [Their distinctions] are like the differences between dogs and monkeys. They do not like each other" (Taiwan Dai-Ajia Kyōkai I938: 27). It also highlighted the way Japan should deal with these different groups: "the Cantonese have the most strenuous and special ethnicity among the Shina peoples. They [the Cantonese] lack understanding of Japan's true merits. Their feelings toward Japan are careless and funny. We therefore have to make a special effort to guide them" (Taiwan Dai-Ajia Kyōkai I938: 27; see also Kikakuin I940: I8). To make a "special effort", a survey by the Taiwan Colonisation Company emphasised the different political connections between the Cantonese and Hokkien leaders in Singapore (Taiwan Takushoku Kabushiki Kaisha I942: II2-II4). It also pointed out that Japanese territorial expansion into the South Seas would create an opportunity to "liquidate the network of the unreasonable overseas Chinese merchants in the region", and to "set up reasonable economic ties with the natives" (Taiwan Takushoku Kabushiki Kaisha I942: I49). In a nutshell, in addition to political considerations, a core concern of Japanese intelligence work remained gathering information to facilitate the establishment of a new economic order in the South Seas.

Discussion of Japan's relationship with other Asian peoples, according to the contemporary sociologist Oguma Eiji, involved not only an understanding of the Japanese past, but also the debate as to "whether Japan's independence could best be protected by returning to native traditions or by assimilating modern civilisation" (Oguma 2003: I4). Given that Japanese competition with other colonial powers in Asia was also crucial to Japanese independence, especially after the outbreak of the Sino-Japanese War in July I937, one may well question how Japan's strategies to expand its power into colonial Asia reflected the Japanese racial understanding of the Chinese in the South Seas. The construction of racial boundaries among the Chinese in Singapore can be seen as a Japanese pre-emptive attempt to challenge rising Chinese solidarity, in concert with growing Chinese anti-Japanese sentiment. Because the Hokkien had been earlier targets of Chinese-Japanese cooperation, while the Cantonese had been identified as competitors for Japanese direct trade to the South Seas, the mistrust and derogatory descriptions of the latter are therefore not surprising. Different from Western colonial expansion, which approached Asia from a perspective of racial superiority and with a Eurocentric 'civilizing' mission, the Japanese empire never developed a consistent racial or civilising discourse about itself, about the foreign peoples under its rule, or about the peoples that the empire aspired to conquer. Japanese racial discourse on Chinese during its imperial expansion, therefore, cannot be explained solely in terms of any single theory 
about the formulation of the Japanese nation or any monotonic portrayal of the Chinese (cf. Oguma 2003; Sakano 2005; Hotta 2007).

\section{Conclusion}

So far the literature has explained Japan's anti-Western imperialism and antagonism towards the Chinese nationalist movements in the South Seas between the I930s and early I940s in terms of Japan's diplomatic setbacks after the end of World War I. These included the rejection of including a racial equality clause at the Paris Peace Conference in I9I9 as proposed by Japan, the Japanese navy's disagreement with the naval cuts agreed at the Washington and London naval conferences in the I920s, and last but not least, Japan's reluctant decision to withdraw from the League of Nations because of the disputes over the Japanese military presence in Manchuria in March I933 (Gotō 2003: I8-23; Shimazu I998: 89-II6; Horne 2004; Hotta 2007). This chapter, however, explains the evolving Japanese views of the Chinese in the South Seas from the oftneglected history of the Japanese-Chinese interactions in the trade in South Seas from the early igios up to the i930s. Beneath the Japanese derogatory term 'Shina' for the Chinese, Japanese policies in cultivating Taiwan-Singapore ties between the I9Ios and I920s were rooted in their awe of the economic success of the Hokkien in the South Seas. From the I930s onwards, when the Hokkien people in Singapore became leaders of Chinese anti-Japanese nationalism, the Cantonese middleman trade continued to present an obstacle to Japan's plan of controlling the Japan-South Seas trade. Both the Hokkien-led Chinese nationalism and the Cantonese-dominated trade of Japanese goods in the South Seas became threats to the expansion of the Japanese Empire.

Throughout these years, the Japanese recognition of Chinese economic dominance in the South Seas in general and Singapore in particular challenged its self-proclaimed 'civilizing mission.' The South Seas Chinese, as well as other Asian peoples in the region such as the Indians and native Malays, were not Japan's yellow man's burdens. They were either strategic allies or critical challengers to the growth of the Japanese empire. And Japan's views of them were continuously shaped, to a large extent, by different Chinese sub-ethnic groups' responses to Japan's expansion. Japan's ideological construction of other Asian peoples and its own relationship with them in the Age of Imperialism, therefore, cannot be fully understood in terms of theories of colonial identities developed from observation of Western colonialism alone. And this construction continued to evolve and to shape Japan's conception of its relation to Asia after the failure of empire in the post-war years. As a major hub 
of Japan's connection with the Southeast Asian region, Singapore will continue to play an important role in this process.

\section{Notes}

I The rest of the region, such as Siam, French Indochina, British Malaya, and the Dutch East Indies, is called the Outer South Sea (Soto Nan' $\gamma \overline{0})$. Later, the geographical scope of the Japanese South Seas expanded. Publication of volume two of the Great South Seas Yearbook (Dai-Nan'Yō Nenkan) in I943 refers to the Nan'yō region as not only contemporary Southeast Asia but also Australia, New Zealand, the Pacific islands as well as India (Nan'yō Dantai Rengōkai I943).

2 Although the Japanese zaibatsu Mitsui Bussan Kabushiki Kaisha set up its first branch office in the South Seas in Singapore in I89I, large-scale expansion of Japanese business to the region did not start until Japan settled its northern affairs with Russia following the Russo-Japanese War and with Korea after colonizing it in I9Io (Yano I975: 68).

3 Among his various involvements in Japan's overseas activities in the I900s, Inoue was a member of Duke Konoe Atsumaro's East Asian Common Culture Association (Tōa Dōbunkai). Konoe's goal was to assist China's modern transformation so as to guard the whole of Asia from further Western encroachments. In I9II, with financial support from the tableware manufacturer Morimura Ichizaemon, Inoue founded a rubber estate in Johore, Malaya (Inoue I942).

4 Based on Nan'yō Kyōkai's 'Annual Business Reports of the South Seas Association', various issues of Nan'yō Kyōkai Zasshi (I9I5-I942).

5 The growth of Japanese tramp tonnages during World War I did not go smoothly, however. It declined to I4,753 in I9I7, probably due to the threat of German unrestricted submarine warfare, which sunk several Japanese steamers in Europe, the Indian Ocean, and in the waters near the northern coast of California. One year after the American participation in the war, in I9I8, the Japanese tramp tonnages in the South Seas rose to I82,330. After the end of the war, the returning European steamers in Asia directly competed with the Japanese shipping businesses in the South Seas. Tramp tonnages therefore declined slightly in I9I9 (Unekawa I927:384; 403-404; 503).

6 The crisis was triggered by financial turmoil in the Taiwan Bank, which followed the bankruptcy of the Suzuki Shōten. The latter left Taiwan Bank with 348,000,000 yen in outstanding debts (Taiwan Ginkō I939: 287-315).

7 In I935, Oei held I60 shares among the 394 shares of the Southern Godown Company from China (Nan'yō Sōko I936: I2-2I).

8 Born in Anxi, China, Lim Pun Tao went to Singapore at the age of 2I and established the Lim Ho Thye Tea Chop. A sideline of the tea agent was a remittance service (Chen Kezhan ed. 1994: 242).

9 Lim Keng Lian was born in China, graduated from Beijing University, and moved to Singapore in the Ig2os to take care of the family tea business, the Chop Lim Kim Thye. The Chop Lim Kim Thye was an established tea agent in Amoy. Through the efforts of Lim Keng Lian's father, the business extended to Malaya. Like other tea agents in Nan'yang, the Chop Lim Kim Thye also engaged in remittance services (Chen Kezhan ed. I994: I80-I8I). For more about his business and life, see Sim (I950: 19-20) and Xiamen Huaqiao zhi bianzuan weiyunhui (I99I: I59).

Io The British tariff became effective after I932. Its initial goal was to protect the markets of British homeland industrial goods (such as textiles from Lancashire), but Chinese manufacturers in Hong Kong and trade agents in Singapore also took advantage of the low tariffs (Kuo 2009). 
II In addition to the I5 Chinese/Cantonese merchants, the other $30.2 \%(3,120,764$ yards) of the trade was carried by 25 Indian merchants, $29.8 \%(3,083,223$ yards) by 10 Japanese companies, and the rest, $3.7 \%$ (383.779 yards) by 8 European agents (Nan'yō Kyökai I934: 96).

I2 Ide associated with Japan's earlier attempts to cultivate 'Japan-China friendship' through his bureaucratic service in Taiwan between 1920 and I938, which included a period as a secretary at the Customs Bureau and a manager of the Association for the Investigation of Tropical Industries (Nettai sangyō chōsa-kai)).He was thus able to build up considerable experience by investigating the trade and customs systems in South China and Hong Kong. He resigned his official posts in December I 938 and after that, his connection with the Japanese government was through writing reports for various intelligence bureaus such as the Mantetsu (Manchurian Railway) on a commission basis. In I94I, he became a professor at the Takushoku University (Kaneko I980). 



\title{
7 The Dynamics of Trans-Regional Business and National Politics: The Impact of Events in China on Fujian-Singapore Tea Trading Networks, 1920-1960
}

\author{
Jason Lim
}

\section{Introduction}

This chapter examines the business network of the Chinese tea merchants in Singapore and the impact of events in China on it. Large numbers of overseas Chinese who had migrated from Fujian to Singapore were familiar with Fujian tea and continued to consume it. This consumption pattern led to the merchants in Fujian opening new firms in Singapore to trade in Fujian tea, especially semi-fermented wulong varieties such as Anxi tieguanyin (安溪铁观音) and Wuyi shuixian (武夷水仙). These merchants arrived in Singapore either to start branches of their families' tea businesses from Fujian or to establish new companies to import, reprocess, and re-export teas.

Before 1949, the National Government of the Kuomintang (KMT) played a negligible role in promoting Fujian tea overseas. It was left to the Chinese merchants in Fujian to seek new markets in Southeast Asia as Chinese tea exports to Western Europe, North America and Japan declined (Buck I997: 9). Southeast Asia was the last place they looked, but their work was made easier by the Chinese community, which was eager to consume home-grown tea. However, cracks in the networks began to appear from the I930s onwards. Political events in China after I949 eventually brought these networks to an abrupt end in I960. Although the Communist government had tried to promote Fujian tea, it was determined that trade should be conducted on the political leadership's own terms.

\section{Expanding the business network}

Since I8I9, Chinese merchants in Singapore had imported tea from China as part of a British colony involved with the entrepot trade. However, they were usually classified as 'general merchants' because tea was only one among many commodities imported. This situation changed 
in the early 2oth century with the arrival of new merchants from Anxi County (安溪县), a tea-growing region in Fujian province, who specialised in the sale of tea in Singapore. The first Anxi merchant to arrive was Koh Beng Jin (高铭壬), who started Koh Beng Huat Tea Merchant (高铭发茶庄) in I905 (the Singapore Ann Kway Association 1974: 357). This firm was the first tea re-processor in Singapore. It would import tea from China, wither the tea to remove excess moisture, mix it with other teas, and then sell the product under a trademark label registered in Singapore. Subsequent tea merchants in Singapore from Anxi would conduct their trade in a similar manner.

Fujian tea production and trade had been on the verge of collapse by the time the Republic of China (ROC) was born in I9I2. Rice, not tea, was the main crop for farmers in Fujian. Tea was grown only to supplement their income. Moreover, the farmers used traditional methods of growing, harvesting and processing tea ( $\operatorname{Lim}$ 20I0: 39-72). The merchants who bought tea from these farmers soon found that there was very little they could do to expand businesses in the province. The ROC was also in chaos with armies loyal to various warlords and the KMT fighting each other for control of the country. The government in Beijing and its rival in Guangzhou were not in a position to help the merchants promote the tea trade. With Japan, Taiwan (a Japanese colony since I895), India and Ceylon all producing and promoting their teas overseas, the merchants had only one area left to promote their products - Southeast Asia, especially the British territories of Malaya and Singapore. This was not surprising as, according to the I92I census, about $74.5 \%$ of Singapore's population was Chinese. Among the Chinese, about 43\% were 'Hokkien' (in other words, people from southern Fujian and their descendants) (Nathan I922: I8, 29 \& 78).

New tea firms were opened in Singapore in the I920s despite a trade depression that had forced many Chinese retail businesses to close (Choo 1976: 32-35). In I920, Guan Cheong Bee Tea Merchant（源崇美茶 庄）was started by Gan Wei Hoon (颜惠芸). In I925, Pek Kim Aw (白 金讴) started Pek Sin Choon Tea Merchant (高建发茶庄). ${ }^{\mathrm{I}}$ An advertisement in the Nanyang Siang Pau in February 1928 reported that a branch of Lim Kim Thye Tea Merchant (林金泰茶庄) had been officially opened in Singapore by Lim See Kok and his nephew Lim Keng Lian（林庆年） (Nanyang Siang Pau, 2 February 1928). Gan, Pek and the two Lims were all from Anxi County. These firms were "small ventures started by enterprising immigrants who provided goods and services required by the local population and could build or sustain a clientele base" (Loh 2004: 64). This base ensured that these firms survived a number of economic crises. Firms in Singapore were often part of a Fujian-Singapore business network. Chip Hong Tea Merchant (集芳茶庄), for instance, was a Chinese firm in Singapore with a factory in Anxi. ${ }^{2}$ Koh Kian Huat Tea Merchant（高建发茶庄） managed three factories in Anxi in I939. ${ }^{3}$ Guan 
Cheong Bee Tea Merchant owned a factory at Zhangzhou and another in Anxi. ${ }^{4}$ Lim Kim Thye Tea Merchant was to be a major tea import/ export company in Singapore until the death of its proprietor Lim Keng Lian in 1968. Lim Keng Lian came from a family of tea merchants. His firm was opened in Xiamen in I9I7 and sold tea harvested from the Wuyi Mountains. The tea would be picked, processed and then exported. In I925, the family decided to expand its business and open branches of Lim Kim Thye Tea Merchant in Southeast Asia. In I927, Lim Keng Lian formally registered the Singapore branch of his family business. By December that year, the firm had eleven factories in Fujian province producing and selling shuixian, Anxi tieguanyin and the expensive dahongpao (大红泡) teas (Nanyang Siang Pau, 8 December 1927). Each year, the firm in Xiamen would also export about 53,300 pounds of wulong to its branches in Malaya and Singapore (Zhongguo Minzhu Jianguohui Fujian Sheng Weiyuanhui \& Fujian Sheng Gongshangye Lianhehui, volume I, I986: I85). Some firms, however, expanded their business in reverse. Guai Sin Kee Tea Merchant, for example, was founded in Singapore, and after accumulating enough capital, the proprietor opened a branch in Xiamen (Yu I991: 159).

The average annual tea crop harvested in China was about $\mathrm{i} 60$ pounds of leaves per acre (Ukers, volume I, I935: 302). Tea harvesting remained a family and/or community affair in Anxi. The dominance of particular families could be seen during the harvesting season. Although picking leaves was generally handled by the family members, regardless of sex or age, the merchants who owned the tea gardens often hired additional pickers from the village. The family of Wee Tiong Yew, for example, who opened Guai Sin Kee Tea Merchant in Singapore in the I930s, hired about four or five villagers to work in the tea gardens. ${ }^{5}$ The family of Guai Lian Kee, who also worked in Guai Sin Kee Tea Merchant, owned large tracts of gardens and hired several dozen odd-job labourers to pick the leaves. These labourers were farmers who owned smaller plots of land and would finish picking leaves from their own plants after one or two days. With no other work in sight, they went to work for the Guai family as paid labourers. Guai estimated that up to sixty per cent of the farmers in Anxi picked leaves for other tea growers. ${ }^{6}$ The tea thus harvested would be processed and shipped to Singapore. Each year, the merchants in Singapore imported about I,322,770 pounds of processed Fujian teas, mostly from Anxi County (Chen I993: 43). As neither China nor Singapore kept official statistics on how much tea the Chinese merchants in Singapore imported from China, an estimate has to be based on the amount imported by the merchants. Guai Sin Kee Tea Merchant imported 3,000 to 4,000 chests of tea per year in the I930s. Since each chest weighed I8 kilogrammes, the annual import for Guai Sin Kee Tea Merchant must have been 54,000 to 72,000 kilos. ${ }^{7}$ 
In addition to supervising the harvesting of leaves from their own tea gardens, the merchants in Singapore would also return to China to purchase as many different types of tea as possible and have them shipped to Singapore. ${ }^{8}$ They could be absent from Singapore for very long periods. Wei Jingzhe (魏静哲) went to Singapore for the second half of the year to settle accounts in Singapore, Malaya, Siam and the Dutch East Indies before returning to China early the next year in time for the Chinese New Year celebrations; he would then not return until the second half of the following year. ${ }^{9}$ Chinese merchants in Singapore also conducted their import/export business with very loose standards of quality control. Some merchants used the tea processed by the Guai family in Anxi as the main standard because of the reputation the family enjoyed as manufacturers of good wulong tea. Merchants from Thailand, Malaya and Burma would flock to Anxi or Xiamen to compare their tea with that of the Guai family's. Should these merchants' tea be better than that of the Guais', the merchants would ask for a higher selling price. In other words, the 'standard' of the tea was up to the tea merchants to decide. ${ }^{10}$ New challenges, however, were appearing over the horizon. The merchants had commenced new family businesses in Singapore throughout the I920s, but their optimism about expanding their networks slowly evaporated from the late I930s onwards. China became embroiled in military conflicts - eight years with Japan and another four years of civil war between the Kuomintang (KMT) and the Chinese Communist Party (CCP). The final victory of the CCP in 1949 brought even more problems for the overseas Chinese merchants.

\section{The first crack in the network: export controls in China}

When war broke out with Japan in I937, the National Government in China saw the need to control external trade and currency exchange in order to finance the country's war efforts (Chi I980; He 1997: 40-53). Tea was a major Chinese export commodity, but much of costal China had fallen into the hands of the Japanese. In May I938, Xiamen, the port where Fujian teas were exported to Singapore, fell, disrupting the Fujian-Singapore trade. The National Government ordered the Foreign Trade Commission (FTC) in the Ministry of Finance to formally exercise control over tea exports. Xiamen could not be used as a port for the Fujian-Singapore tea trade and the FTC shifted its operations to Britishheld Hong Kong. Merchants had to obtain a 'foreign exchange certificate' issued by the Fu Hua Trading Company - the subsidiary of the FTC based in Hong Kong - to be allowed to export tea. ${ }^{\text {II }}$

Since the National Government made it compulsory for the merchants to export tea from Hong Kong, the merchants in Singapore felt compelled to respond to the new regulations. The Singapore Chinese 
Tea Importers and Exporters Association (SCTIEA), founded in I928, decided to respond by expanding their business networks. No details of how and why they did this were recorded in the minutes of the SCTIEA, but an expanded network may have made 'block purchases' to create economies of scale. Furthermore, rather than limit themselves to their own parochial business interests in Singapore, the merchants began to contact other tea merchant associations in Southeast Asia. An association representing all Chinese merchants in the region was ideal since it could negotiate with both the National Government in Nanjing and the Fujian Provincial Government (FPG) in Fuzhou. In I939, the SCTIEA discussed the feasibility of creating an organisation that would be a single voice for the merchants in Singapore, Malaya, Burma, French Indochina and Siam: the "Federation of Overseas Chinese Tea Merchants in the British, French and Siamese Territories" (英法暹三属华侨茶商联合会)..$^{22}$ This proposal remained an ideal as the merchants were naïve, underestimating the difficulty of setting up an organisation that cut across territorial boundaries. They would have to work with the regimes in the different territories of Southeast Asia at a time when anti-Chinese policies were introduced and when the region had only just recovered from the effects of the Great Depression. Since the reign of King Vajiravudh (I9IO-I925), the Siamese had shown a disdain for a people considered to be the "Jews of the Orient" (Vella 1978: 193-I94) within their borders and the French aimed to reduce Chinese business influence in Indochina. With the end of the Great Depression, the governments in Malaya and Siam introduced greater regulation of their economies (Chen I978: 264 \& 270; Tay I962: 35). The difficulty of setting up such an organisation made the SCTIEA aware of the political and economic situation around Singapore, and a year later, it scaled down its proposal and put forward the possibility of setting up a “Malaya Tea Company” (马来亚茶叶公司). . $^{3}$

Despite the greater feasibility of this plan for purchasing Fujian tea on behalf of all Chinese merchants in Malaya and Singapore, it was never discussed again in the meetings of the SCTIEA, as war loomed closer. Exhibiting overseas Chinese nationalism targeting Japan was more appealing than planning regional business deals. Drinking tea had become a symbol of patriotic behaviour by the Chinese community and the merchants had to show that they were promoting Fujian tea as a Chinese 'national product' (Lim 2008). The roots of the 'national products' movement lay in China in I928; the promotion and sale of Chinese goods were regarded as patriotic because money accruing from the transactions was returned to China. 'National products' exhibitions had been organized in Singapore in 1932, I935 and 1936 and the tea merchants had participated in them. The merchants were also expected to exhibit their patriotism by boycotting Taiwan tea (including the famed 'Formosa Oolong') in their purchases, as Taiwan was a Japanese colony. ${ }^{14}$ 
Unfortunately, tea export controls by the National Government badly affected the merchants' business network, at least until the end of the war in I945. The supply of tea for the merchants in Singapore was no longer assured. Businesses suffered even more when the National Government insisted that the merchants must comply with new regulations introduced on I5 March I940 that allowed the FPG to keep track of sales to ensure that tea was exported only to overseas Chinese merchants. The FPG monitored the sales so closely that merchants could not even carry small quantities of tea out of the province to distribute to their relatives or for personal consumption. ${ }^{15}$ In desperation, the merchants in Singapore, having failed to organise a single organisation of tea merchants in Southeast Asia or a company representing them in Malaya, appealed directly to the China National Tea Corporation (CNTC), an organisation founded by the National Government in I 937 to work on national tea production and trade.$^{16}$ As if the merchants did not have enough troubles, the CNTC responded by drafting another set of regulations called the "Supervisory Plan for Settling Remittances from Tea Exports to the Overseas Chinese" （侨销茶叶结汇出口鉴定办法） in November I940. The merchants now had to register their firms with the Chinese Consulate in Singapore. ${ }^{\text {I7 }}$ These additional measures were strictly applied to any merchant who had purchased tea from Fujian, Guangdong and Yunnan provinces, who owned a factory to process such tea, or who had opened an overseas branch of the firm. The measures introduced by the National Government to control tea exports continued to be a major source of concern for the merchants until war broke out in the Pacific in December 194I. By the time the British surrendered Singapore to the Japanese in February I942, the tea merchants had begun to cease business operations. Some firms even remained closed throughout the three-and-a-half years of the Japanese occupation of Singapore.

\section{Another crack in the networks: rivalry from Taiwan tea}

The end of World War II in September I945 brought a new challenge for the merchants in Singapore. Contacts with their families, friends and business partners had been re-established and there was a hope that the old pre-war business networks could be revived and expanded. Trade routes re-opened in 1946 and there was a steady increase in the demand for tea. ${ }^{18}$ Yet the war had a devastating effect on the Fujian tea industry. Tea plantations had been laid to waste. High overheads and transportation costs added to the problems. There appeared to be no hope for a revival of exports. A war-weary commentator wrote about how "it appears that shipments were effected solely to remind foreign customers that Fukien tea is still being grown" (Chen I947: 270). 
Fujian tea now faced competition from another source: Taiwan. The return of Taiwan to the ROC in I945 actually presented another challenge to the merchants in Singapore as both provinces processed and exported semi-fermented teas such as wulong to Southeast Asia. In October I948, while Fujian exported about Io,००० chests of tea to the region, Taiwan had exported a million chests (Xiamen Shi Dang'an Ju \& Xiamen Shi Dang'an Guan I997: 74). Even more perplexing to the merchants was that Taiwan tea was cheaper. Should they forsake Fujian tea and use the cheaper Taiwan tea as a substitute for their trademark labels or should they remain loyal to their home province by continuing to import and sell Fujian tea?

The problem was magnified with the end of the civil war on mainland China. In December I949, the KMT moved the seat of the National Government of the ROC to Taipei and most of Fujian province (including Anxi County) became part of the CCP-governed People's Republic of China (PRC). Purchasing Taiwan tea could be misconstrued as a message to the PRC that the merchants were KMT loyalists. Several merchants such as Lim Keng Lian were indeed sympathetic to the KMT cause (Lim 2007: 2IO-2II) but, bearing in mind that Fujian tea was still consumed by Fujian immigrants in Singapore, it might be detrimental to their business interests if they were seen to be actively importing and selling Taiwan tea in place of Fujian tea. The end of the civil war also saw both the ROC and the PRC wooing the merchants for continuation of the tea trade even though the continuous rise in Fujian tea prices made the cheaper Taiwan tea an obvious alternative. The price difference could be substantial. In June I950, the SCTIEA noted that while Wuyi Qizhong tea (武夷奇种茶) from Fujian cost S\$ 36 per catty, Taiwan Nankang tea（台湾南港茶） imported through Hong Kong cost about S\$200 per picul (or S\$ 2 per catty), although members had to factor in foreign exchange rates in Taiwan and export fees in Hong Kong. ${ }^{\text {I9 }}$

The picture became clearer to the merchants as the years passed. Whereas in I949 the merchants found the price of Fujian tea to be too high, they knew by the mid-I950 that there had been a shortfall in tea production in the province since I949. The Fujian wulong tea trade registered a shortfall in I956, but the continued importance of Anxi for the production of wulong tea was evident as this county alone produced almost $83 \%$ of the entire provincial output. While the shortfall in production was a source of concern for the Department of Agriculture in the Jinjiang Prefectural Commissioner's Office, it noted the advantage that Fujian enjoyed as it faced no competition from Taiwan in the production and export of highgrade wulong. The Department proposed that Anxi County should export more tieguanyin since a huge overseas demand was expected. ${ }^{\circ}$

The merchants in Singapore also accepted the claim put forward by the China Tea Company (CTC) - formed in November I949 to co-ordinate tea production in China - that higher prices meant better 
quality teas. The new assertion was made at a crucial time, coming barely a week after the merchants had been assured of favourable exchange rates from Taiwan. In July I957, the SCTIEA was one of three organisations invited by the KMT Government to join an official trade mission from Malaya and Singapore to Taiwan. In that same month, the Xiamen branch of the CTC informed the merchants that Fujian tea prices had increased again, but claimed that the improvement in the quality of exports had led to higher production costs for the farmers. This resulted in an increase in the price of exports with the prices of low-grade teas increasing by as much as 30 per cent, while prices of high-grade teas rose by 25 per cent (Nanyang Siang Pau, 24 July I957). During an official visit to Taiwan, members of the SCTIEA had met Taiwanese tea producers and merchants to discuss the possibility of enhancing trade relations (Lim 2007: 2II). Not long after the mission returned home, the Xiamen branch of the CTC sent free samples of wulong to the merchants.

In reality the purchase of tea was more a matter of taste than related to production methods. In I958, the best tea from Taiwan - 'Biao Zhun Dui' tea - cost S\$ I.5O per catty, which was equivalent to the price of third-grade wulong from China. Tieguanyin from Fujian cost S\$ I2 per catty, but the price difference was now accepted by merchants in Singapore as evidence that the quality of China tea was better than that of Taiwan tea. ${ }^{2 \mathrm{I}}$ Yet, the merchants continued to wait for the prices of Fujian tea to fall. In October that year, the Nanyang Siang Pau finally reported that the price of China teas in 1958 had fallen by I3 per cent. ${ }^{22}$ This was the first time in a long while that the merchants in Singapore had any good news concerning tea prices. The merchants did not equate falling prices as a sign that the quality of tea might have dropped.

\section{The final straw: the new political agenda in China}

Most pre-war firms in Fujian continued with 'business as usual' in the early years of the Communist regime. Private businesses were encouraged to continue trading with overseas Chinese enterprises to get foreign currency (Zhongguo Shehui Kexue Yuan \& Zhongyang Dang'an Guan 199г: 6I8). The production of tea for Southeast Asia continued much as before (Zhongguo Chaye Gufen Youxian Gongsi \& Zhonghua Charen Lianyihui 200I: 223). However, the first years after the victory of the CCP in I949 were difficult ones for the tea merchants in Singapore. Their trade was cut off by both the Central People's Government in Beijing, who were suspicious of private enterprise and by the ROC Navy, which was blockading the Chinese coast. There was every possibility that the merchants might lose their tea gardens and family businesses. This 
would have a significant impact on their business networks, because their supply of tea could be suddenly cut off, reducing their business to just retail outlets in Singapore (and across Southeast Asia if they had any). It did not help that merchants were victimised by the land reform programme introduced by the CCP. A renowned firm in Fujian such as Zhang Yuan Mei Tea Merchant (张元美茶庄), founded in I9I8 in Anxi with branches in Xiamen, Zhangzhou, Hong Kong, Rangoon and Guangzhou, had their tea gardens in Anxi and the Wuyi Mountains confiscated and redistributed to the tea farmers by I950 (Zhang I997: 22I). The importance of this would not be missed by the merchants in Singapore.

Over the next few years, the merchants in Singapore all suffered in some way as their business networks slowly crumbled. Despite having capital assets of C\$200,000 and another C\$200,000 invested in Xiamen from branches in Southeast Asia, Lim Kim Thye Tea Merchant closed its Xiamen office in I949 (Lin 2004: 86). Guai Sin Kee Tea Merchant also lost its gardens, a factory and the old head office in Xiamen to the Communist government in I950. Its landed properties in Xiamen were all seized by the CCP, which went on to accuse the firm of being 'big landlords' (大地主). ${ }^{23}$ Wei Jingzhe, the proprietor of Guai Sin Kee Tea Merchant, had to flee China after his family business assets were seized. He settled down in Singapore and his wife and children eventually joined him in $1956 .{ }^{24}$ Although the Central People's Government later allowed the overseas Chinese to return home to cultivate wasteland for agriculture, the official position was that they had to work towards a 'socialist transformation' of their private businesses (Hughes \& Luard I961: 20-22; Mao I993: 75-78). In I95I, the 'Five-Antis' campaign targeted owners of private firms (Sun I992: 79-82). It is not known how many tea merchants in Fujian were targeted as a consequence of the campaign. It is, however, known that, across China, many merchants were publicly humiliated, fined heavily or driven to suicide. Political pressure was imposed on the merchants to discredit them in public and subject them to state control (Hughes \& Luard I961: 90).

Nonetheless, by the late I950s, the attitude of the overseas Chinese merchants towards the PRC had changed. They no longer believed that the KMT would recover the mainland; the Fujian-Singapore tea trade had to continue with the CCP administering the province. With the mainland under the CCP, each tea merchant felt safer to restart business operations, using Singapore as the nexus of a new business network. Their suspicions of the political agenda of the CCP, which included 'socialising private enterprise, made them regard China now as a potential trading partner rather than their homeland (Huang I995: I6I-I92). Despite the loss of political and cultural connections with Fujian, the merchants wanted to maintain economic and business links. This demonstrates 
that "the maintenance of economic ties with China was mainly for personal economic gains rather than out of their burning desire to be of service to the motherland" (Goh I987: 62). The merchants were prepared to ignore different political viewpoints in favour of economic realities. When citizenship was introduced in I957, the tea merchants applied to be Singapore citizens. There was no reason for them to return to a China where the government had seized landed property and now controlled tea production and trade.

After all, tea continued to be exported to Southeast Asia from Xiamen - from 998,317 catties in 1950 it increased to 266,307 catties in 1952. In August I953, out of 34 tea firms in Xiamen, at least eight exported tea to Singapore. ${ }^{25}$ It was under these circumstances that Koh Kian Huat Tea Merchant opened its first branch in post-I949 Xiamen in December $1953{ }^{26}$ The situation, however, changed for the worse by the end of I953 with the announcement by the Central People's Government that there was no place for private enterprises in China. Their work would be taken over by state enterprises and co-operatives. The CTC purchased all the tieguanyin produced by farmers in Anxi County and then sold the tea to the merchants in a bid to 'replace the free market'. ${ }^{27}$ The tea industry was now a state enterprise but the commodity continued to be sold in small packages like before, with 50 different brand names of Fujian tea. Exports of wulong tea exceeded the 1936 peak level by thirty-five per cent in 1957 and were mainly exported to 'capitalist countries' such as Burma, Malaya, the Philippines, Borneo and Canada (Fujian Ribao, 7 March 1957). In I956, a government campaign absorbed private businesses into new 'joint state-private enterprises' as part of a programme to enforce state control over trading activities (Hughes \& Luard I96r: 94-95). State enterprises in China increased from I9.I per cent of all firms in 1952 to 33.2 per cent in I957; co-operatives also increased from I.5 per cent to 56.4 per cent in the same years. Conversely, sole proprietorships fell from 7I.8 per cent in 1952 to a mere 2.8 per cent in I957 (Xie \& Luo I990: 9). With Fujian tea production and export now under state control, the merchants in Singapore found it difficult to get a continual supply of tea - they had lost their personal contacts with the end of private enterprise and the state had decided that the commodity should also be exported to other countries.

\section{The end of the business networks}

The increasing awareness of the PRC as a potential trading partner in Fujian tea did not improve matters for the merchants in Singapore. Their business networks also suddenly came to an end. In January I959, 
the manager of a Taiwanese tea firm was introduced to the SCTIEA. He urged members of the association to continue purchasing Taiwan tea. He reiterated that Taiwan tea was cheaper than tea exported from mainland China. Unfortunately, the members of the SCTIEA were unimpressed by his appeal because the prices of Fujian tea were falling even before he arrived in Singapore. Some of the members became even less impressed when they noted the low sales of Taiwan teas in Southeast Asia. This reinforced their belief that Taiwan tea was inferior. ${ }^{28}$ In June, members of the SCTIEA were shown nine boxes of tea samples - a gift from the CTC. This attempt to raise the stakes came at a time when Fujian tea exports to Singapore were decreasing just as Taiwan was trying to increase its exports. In July, the ROC Government in Taiwan made 'strong efforts' to export more tea to Malaya and Singapore, apparently because of a decline in imports of China tea. ${ }^{29}$ Taiwan tea was shipped to Singapore via Hong Kong, and yet sold at prices about Io per cent lower than China tea. While Taiwan tea was regarded as 'generally inferior' to China tea, Taiwan had offset this to some extent by making more special offers and introducing more varieties to the Singapore market.

The Taiwanese plan to export more tea to Singapore was matched, however, by a push from the PRC offering exclusive rights to particular Singapore merchants who sold Fujian tea. The Xiamen branch of the CTC offered three local tea firms - Koh Kian Huat, Kim Leng Thye and Guan Cheong Bee Tea Merchants - a deal whereby they could purchase all their Fujian tea from the Xiamen branch of the CTC. Unfortunately, this discussion had occurred without prior approval by other members of the SCTIEA, who understandably were upset. However, the CTC continued to send letters to Kim Leng Thye Tea Merchant, urging the formation of a single company for trade in Fujian tea. ${ }^{30}$ The CTC wanted to trade with a single trading company rather than many individual firms in Singapore. It was also likely that the tea firms in Singapore had very little influence on the Fujian-Singapore trade by this time and they were forced by the CTC to organise a single trading company. Hia Huan Quee, proprietor of Tian Hiang Tea Merchant, recalled that the 'Chinese authorities' had imposed restrictions on the tea trade between China and Singapore. From now on trade would only be conducted by the 'Chinese authorities' with a single company in Singapore and the merchants were expected to purchase tea in bulk through this company from the 'Chinese authorities', who would take a one or two per cent commission from the merchants. ${ }^{31}$

With pressure from the CTC and fears that the Fujian-Singapore tea trade could be adversely affected, the merchants in Singapore decided to comply and Giam Kay Tea Company (Pte) Ltd was registered on 9 July I960. ${ }^{2}$ The proprietors of the member firms joined the Company as 'Singapore citizens' and all trade in China was now in the hands of the 
Central People's Government. The tea firms in Singapore had to place their purchase orders to the CTC through Giam Kay (Singapore Ann Kway Association I992: I74). After the tea arrived in Singapore, it was distributed to member tea firms for re-processing and packing in their trademarked packets. ${ }^{33}$

\section{Conclusion: regional connections and business networks}

Claudine Salmon once wrote that "we still know little about the regional networks formed by merchants of Chinese origin" because "they did not document their history, which they preferred to keep secret for understandable political reasons" (Salmon 2000: 329). While it would not be appropriate to generalise and assume that the experiences of the tea merchants were similar to those of all Chinese merchants in Singapore, there was always the possibility that some merchants did experience the same process, as they observed the slow breaking up of their business networks and/or business empires. A merchant would open new businesses if there were opportunities for him/her to do so. However, whether the merchant could maintain and use the business contacts may be beyond his/her control.

Singapore enjoyed a unique position in history, being declared a free port when the British arrived in I8I9 and remaining a port for the entrepot trade until full independence was achieved in I965. This unique position made the island very attractive for trade, usually at the expense of other states, which were facing dire circumstances, both politically and economically. The business environment was also a major factor in drawing the merchants to Singapore to trade. In the case of the tea merchants, the presence of large numbers of Chinese who consumed Fujian tea became the main pull factor. This was the impetus that brought tea merchants from Fujian - either seeking a better livelihood or merely in order to open new businesses - to come to Singapore in what came to be regarded as a good outlet for trade.

Yet, leaving China and starting a new business meant that for those involved in the China trade, the nexus of their business networks was China, not Singapore. They were at the mercy of regional and/or international events that had an impact on China even though they were miles away in Singapore. With their status as 'overseas Chinese', they were also tied politically with China as there was no such identity as 'Singaporean'. When Japan became increasing belligerent towards China, the merchants felt justified in campaigning for Chinese goods such as tea to be labelled 'national products' and boycotting Japanese and Taiwan teas as 'enemy goods'. Their identity as 'overseas Chinese', however, also meant subjecting themselves to the government of the day in China. When the National 
Government introduced export controls in I938, it was in response to the national concern that hard-earned currency could find its way to Japan and/or the Japanese puppet regimes of Wang Jingwei and the Emperor of Manchukuo. Export controls, however, affected the merchants' business networks badly. Would criticism of export controls by the merchants then be considered as an act of self-interest or anti-government protest in a time of war? The merchants had to tread the nationalistic ground very carefully, as their actions could be misconstrued as treacherous.

The end of the Chinese Civil War effectively marked the death knell for the tea merchants' business networks. Cheaper Taiwan tea entered the market just as prices of Fujian tea soared. The situation in Fujian after I949 brought new problems for the merchants, especially when the communists decided it was time to eradicate private enterprise and bring all the merchants under the control of state enterprises. None of the tea merchants in Singapore were known to have spoken out openly against this 'socialist transformation' of private enterprise in Fujian from the I950s, but the new regulations on the conduct of trade in Fujian ultimately ruined their business networks. The merchants in Singapore lost their gardens to land reform schemes and their family's assets in Fujian were seized. The merchants in Singapore now had to operate on their own. Throughout the I950s, they tried to establish new networks by importing the cheaper Taiwan tea, but ultimately the appeal of Fujian tea drew them back to the negotiating table with the Chinese government. In I960, as the Chinese government insisted on trading with one company instead of several Chinese firms in Singapore, the Giam Kay Tea Company was established. With that, the 'independence' the tea merchants in Singapore had enjoyed as a result of their business network came to an abrupt end.

Despite the obvious regional connections in the Fujian-Singapore trade - through business networks - the merchants still need stability in their personal lives. While trying their best to tackle these predicaments, the Chinese tea merchants in Singapore remained largely powerless as the root of their problems lay in China itself. They could not depend on their networks and their experience had taught them that they could not look to China for stability even though Fujian was central to their business interests. The answer was to adopt Singapore citizenship when it was introduced in I957. First, in an ironic twist of history, stability in the China trade could only be achieved if China did not remain the nexus of their business networks. As Singapore citizens, the merchants were freed from depending on their old networks for business stability. They could now purchase semi-fermented tea from Taiwan or green tea from Japan if they wanted to. The merchants simply had to make Singapore the nexus of their business networks after I957. Second, since the entire Fujian tea production and 
trade became the responsibility of the CTC, the merchants knew they could not depend on their pre-1949 business networks as these had been effectively destroyed by the communists. The formation of the Giam Kay Tea Company (Pte) Ltd in I960 confirmed their suspicions that the old networks could no longer be used for their trade. Similar arrangements were made by the textile traders in Singapore in response to the call from China for a single textile trading company to trade with. It would be impossible to negotiate with the CTC or even Chinese government officials if they retained their status as 'overseas Chinese', a term which implied politically loyalty to the PRC. The KMT loyalists among the merchants also knew they would not be welcomed by the communists should they return to China. Calling themselves Singaporeans was a way of ensuring their own protection and that of their business interests.

The pre-I949 Chinese business networks also morphed into a network of regional connections after the mid-I950s. Before fighting began in the Pacific theatre of World War II in December I94I, the trade networks were based on the consumption patterns of their clientele. The tea merchants from Fujian opened up new businesses in Singapore because of their belief that the large numbers of Fujian immigrants would consume Fujian tea. Their familiarity with the buying, selling and re-exporting of the commodity also put them at an advantage over tea merchants from other provinces in China. The Fujian tea merchants might not have moved to Singapore if a large section of the Chinese population was to consume, say, Zhejiang tea, since their knowledge of the production and selection of semifermented teas from Fujian would then be useless. After 1949, the familiarity of a commodity was no longer what the merchants offered to their clientele. They were no longer loyal to a particular product - if another state or territory produced similar products, the merchants would attempt to purchase them. The Chinese in Singapore were still consuming Fujian tea in the I950s even as the tea merchants were looking for cheaper alternatives from Taiwan. The merchants learned not to rely solely on the China trade as they sought new areas of production and markets across East and Southeast Asia. Chinese control of the Fujian trade continued for the next two decades. It survived the Cultural Revolution and the death of Chairman Mao Zedong in China. When China finally opened its doors to the world for international trade in 1982, these controls ended and the merchants could once again trade freely with China. 


\section{Notes}

I Chinese Newspapers Division, Singapore Press Holdings (SPH-CND), Yinlia Gongye 饮料工业 (Beverage industries), newspaper clippings from I950 to I996, 'Bai Xinchun Chazhuang - Pinming Zhijia’ 白新春茶庄〜品茗之家 (Pek Sin Choon Tea Merchant A Tea Company), Lianhe Wanbao, ig June I996.

2 Second Historical Archives of China (SHAC), Foreign Trade Commission Archives, Accession No. 309/3152, Letter from Xie Chuanji（谢传集） of Chip Hong Tea Merchant to the Foreign Trade Commission (henceforth FTC), I6 January I940.

3 SHAC, Foreign Trade Commission Archives, Accession No. 309/3152, Letter from Koh Hoon Peng of Koh Kian Huat Tea Merchant to the FTC, 22 January I940.

4 SHAC, Foreign Trade Commission Archives, Accession No. 309/3134, Letter from Ministry of Finance to the FTC, 5 December 1939.

5 Oral History Centre $(\mathrm{OHC})$ at the National Archives of Singapore, Wee Tiong Yew, Accession No. Aooo660/06, 1986, reel 2.

6 OHC, Guai Lian Kee, Accession No. Ao02252/IO, 2000, reel I.

7 OHC, Guai Lian Kee, Accession No. Ao02252/10, 2000, reel 3.

8 SPH-CND, Yinliao Gongye 饮料工业 (Beverage industries), newspaper clippings from I950 to I996, 'Gulao Chazhuang, He Gongfu Cha'古老茶庄, 喝工夫茶 (Old tea firm, drinking Congou Tea), Shin Min Daily News, I7 July I986.

9 SPH-CND, Yinliao Gongye 饮料工业 (Beverage industries), newspaper clippings from I950 to I996, 'Chaxiang Liufang Yibai Nian' 茶香流芳一百年 (Reputable tea for a hundred years), Lianhe Wanbao, 9 July I992.

Io OHC, Guai Lian Kee, Accession No. Ao02252/Io, 2000, reels I and 4.

II SHAC, Foreign Trade Commission Archives, Accession No. 309/2395, Memorandum from Foreign Trade Commission to Ministry of Finance, 20 June I938; SHAC, Foreign Trade Commission Archives, Accession No. 309/2395, Telegram from Ministry of Finance to the Kowloon Customs Service, Hong Kong, and 26 June I938.

I2 National Archives of Singapore (NAS), Microfilm No. NA 53I, Records of the Singapore Chinese Tea Importers and Exporters Association (henceforth SCTIEA), Minutes of Annual General Meetings and Executive Committee Meetings, 2nd Staff Meeting on 29 March 1939.

I3 NAS, Microfilm No. NA 53I, Records of the SCTIEA, Minutes of Annual General Meetings and Executive Committee Meetings, 3rd Emergency Meeting on 3I July I940.

I4 Chinese Business History Research Centre, Economic Institute, Shanghai Academy of Social Sciences (CBHRC), Accession No. 05-029, Shangye, Neiwai Maoyi: Chaye Shengchan Yu Shichang 商业、内外贸易: 茶叶生产与市场 (Businesses and Domestic \& Foreign Trade: Tea Production and Market), page oor8, 'Nanyang Huaqiao Aiguo Xinqie Juyong Taiwan Cha' 南洋华侨爱国心切拒用台湾茶 (Overseas Chinese in Southeast Asia eagerly reject Taiwanese tea out of patriotism), newspaper unknown, 26 May 1938.

I5 Old Periodicals Repository, Xiamen University Library (XMUL), Chaye 茶业 (Tea trade), 'Chaye Wulun Duoshao Buzhun Xiedai Chuyang' 茶叶无论多少不准随带出洋 (Tea not allowed to brought out of the country), 'Hui Zhong' 惠钟 (newspaper), I9 April I940; and XMUL, Chaye 茶业 (Tea trade), 'Chuguo Qiaomin Buzhun Xiedai Chaye’ 出 国侨民不准携带茶叶 (Overseas Chinese not allowed to bring tea out of the country), 'Fu Xin' 福新 (newspaper), 22 April I940.

I6 SHAC, China National Tea Corporation Archives, Accession No. 273/39I, Letter from the Foreign Trade Commission to the China National Tea Corporation, 22 August I940.

I7 SHAC, China National Tea Corporation Archives, Accession No. 273/39I, 'Plan of Appraisal of Remittances through Tea Exports to Overseas Chinese', undated (probably August 1940). 
I8 Archives of the Institute of Modern History Academia Sinica (IMHA), Economic Archives from Mainland China, Accession No. 20-00-2I-II-3, Fujian Sheng Zhengfu Fuyuan Gongzuo Baogao 福建省政府复员工作报告 (Report on rehabilitation work by the Fujian Provincial Government), Report by Zhang Tianfu (张天福), Director of the Fujian Province Agricultural Improvements Bureau（福建省农业改进处）, to the Minister of Agriculture and Forestry, March I947, n.p.

I9 NAS, Microfilm No. NA 53I, Records of the SCTIEA, Minutes of Annual General Meetings and Executive Committee Meetings, Executive Committee Meeting on Io June I950.

20 Quanzhou City Archives (QZCA), Quanzhou City Agriculture Bureau Archives, Accession No. I2I-2-42, 'Guanyu Wulongcha Chanxiao Wenti De Baogao' 关于乌龙茶产销问 题的报告 (A report about the problems concerning the production and sale of wulong tea), 5 January 1957.

2I SPH-CND, Yinliao Gongye 饮料工业 (Beverage industries), newspaper clippings from I950 to I996, 'Chashi Fengguang' 茶市风光 (Overview of the tea market), Nanyang Siang Pau, I9 September 1958.

22 SPH-CND, Yinliao Gongye 饮料工业 (Beverage industries), newspaper clippings from I950 to I996, 'Zhongguo Chaye Shoujia Yidi' 中国茶叶售价抑低 (Chinese tea prices lowered), Nanyang Siang Pau, 27 October 1958.

23 OHC, Guai Lian Kee, Accession No. Ao02252/IO, 2000, reels I and 5.

24 OHC, Guai Lian Kee, Accession No. Aoo2252/10, 2000, reel I.

25 QZCA, Quanzhou City Trade Development Bureau Archives, Accession No. I33-I-5I, Xiamen Chaye Shichang Diaocha Baogao 厦门茶业市场调查报告 (Investigative report into the tea market of Xiamen), August I953, n.p.

26 NAS, Microfilm No. NA 53I, Records of the SCTIEA, Minutes of Annual General Meetings and Executive Committee Meetings, Executive Committee Meeting on 3I December 1953 .

27 XMUL, Yancha Chanxiao 烟茶产销 (Production and sale of tobacco and tea), 'Anxi Chaye Shengchan Zai Buduan Fazhan Zhong 安溪茶叶生产在不断发展中 (Production of tea in Anxi continues to develop), Xiamen Ribao 厦门日报, 27 October I954.

28 NAS, Microfilm No. NA 53I, Records of the SCTIEA, Minutes of Annual General Meetings and Executive Committee Meetings, Executive Committee Meeting on I3 January I959; and NAS, Microfilm No. NA 53I, Records of the SCTIEA, Newspaper Clippings, Nanyang Siang Pau, I6 January I959.

29 English and Malay Newspapers Division, Singapore Press Holdings (SPH-EMND), Beverages - Tea, newspaper clippings from I959 to I99I, 'Taiwan Plans to Send Us More Tea', The Straits Times, 3 July I959.

30 NAS, Microfilm No. NA 53I, Records of the SCTIEA, Minutes of Annual General Meetings and Executive Committee Meetings, Executive Committee Meeting on 8 February I960.

3I OHC, Hia Huan Quee, Accession No. Aooo685/05, I986, reel 4.

32 SPH-EMND, Beverages - Tea, newspaper clippings from I959 to I99I, 'Tea: Singapore Traders Accused of Move to Corner Mart', Singapore Free Press, 8 March 1960.

33 SPH-CND, Yinliao Gongye 饮料工业 (Beverage industries), newspaper clippings from I950 to I996, 'Gulao Chazhuang, He Gongfu Cha' 古老茶庄, 喝工夫茶 (Old tea firm, drinking congou tea), Shin Min Daily News, I7 July I986; and OHC, Gan Tiong Siew, Accession No. Aoo2915, 2005, reel I. 


\title{
8 Rambutans in the Picture: Han Wai Toon and the Articulation of Space by the Overseas Chinese in Singapore'
}

\author{
Lai Chee Kien
}

Around eighty percent of the estimated 25-30 million overseas Chinese in I4O countries around the world live in the countries that comprise Southeast Asia. (Wang 2005: 4) This large number is due to Southeast Asia's proximity to China, with outmigration from its southern coastal areas commencing around the I6th century at a time when the region's polities gradually became colonised or determined politically by European powers. The ratio of overseas Chinese to other ethnic populations in the region's nations has remained more or less constant through ensuing settlement, trade and social relations.

Up to now, scholarship on the space inhabited by the Chinese diaspora around the world has focused on sites of labour or enclaves known as 'Chinatowns' and the socio-economic spheres and built environments created in the new host cities as hybrid renditions. The coalescing of constitutive communities into a common 'Chinese' identity in those countries is an essential premise for such work. The overseas Chinese spaces or enclaves in Southeast Asia, however, need to be discussed differently from the Chinatowns of America, Australia or Europe because of their large populations, histories and spatial make-up.

The history of Singapore and its large ethnic Chinese population may be aligned along such a general narrative of diaspora in Southeast Asia. In this case, the British colonisers welcomed external populations in their colonies to drive imperial commerce and to compete and disrupt pre-existing local/regional economic patterns. From textual accounts, it is known that the human landscape soon after the establishment of the island's free port in I8I9 was cosmopolitan, but the exponential increase in immigration from Southern China and the immigrants' eventual control of various spheres of influence would alter the island's subsequent history. At the beginning of World War II, $43 \%$ of the population was registered as ethnically Chinese. This statistic is now about $75 \%$ and the Chinese are currently the majority ethnic category in censuses.

Chinese immigration to Singapore can be seen as a continual process since British colonisation in I8Ig. The first Chinese immigrants were mainly contract and indentured labour, but the communities grew and soon the need for schools to educate the locally-born was advanced. 
This was perceived as vital in order to augment their social and economic positions as settler communities and as individuals. At the turn of the 2oth century, Chinese language newspapers and vernacular schools were established and this attracted more literate Chinese to the South Seas (南洋, Nanyang) to fill the various teaching and administrative positions. This new group of immigrants eventually became the key movers and leaders of diasporic cultural and literary spheres through their involvement in newspapers and schools, as well as in the formation and stewardship of business guilds, societies and institutions. From primary and secondary schools, other educational facilities would also be started, for example an art academy (the Nanyang Academy of Fine Arts) in 1938 and a Chinese language university (Nanyang University) in 1956.

In this chapter, I discuss and compare the various enclaves of a minority Chinese community in Singapore. I describe how the British colonial project was originally concentrated on the southern part of the island and trace the formation of the urban Hainanese enclave in relation to two areas of overseas Chinese settlement on either side of the Singapore River. I then follow the movements of one particular Hainanese immigrant from his arrival in the early part of the 2 oth century, his settlement in the urban enclave and then in the suburbs, before his return to China in the I96os, after almost half a century of residence in Singapore. I also argue that botany and the engagements with plants and plant products were central to interpreting the literary, artistic and scholarly interests of the overseas Chinese and their acclimatisation to new conditions and milieus in the equatorial tropics. This gained potent intellectual and spatial expression in the Hainanese immigrant's creation of a rambutan orchard during the inter-war period. By discussing a commemorative painting of that orchard by a locally-born artist, I contrast the perceptions, attitudes and experiences of two generations of the overseas Chinese in Singapore, as well as the forms and tenors of their intellectual spaces.

\section{Enclave formations and the Hainanese community}

In Singapore, the categorisation of ethnic denominations was an attempt to map its diverse communities and also as a means of surveillance and control by British administrators. Besides glossing over the distinctions that existed between the different sub-ethnic communities, the use of simple categories such as 'Indians' and 'Chinese' for spatial division in the early colonial town plans subjugated the hegemonies among the different settler groups and discounted the dynamic nature of such multi-ethnic communities.

It is recorded that a number of Chinese gambier farmers were already establishing plantations on the island under the aegis of descendents 
of the Johor-Riau Empire in I8I8. Thomas S. Raffles, acknowledged as the first British settler of colonial Singapore, altered its southern coastal landscapes soon after arrival in I8I9 by creating a cantonment between two river systems. The European Town was located to the northwest of this cantonment and both were connected by four roads running parallel to the coast. The perpendicular road to the four, Middle Road, marked the midway line between the Sultan's residential compounds and the cantonment at the Singapore River. Many institutions such as churches and schools are indeed located on the fringes of the government area today to mark the Europeans' early settlement in the designated town area, but they were later displaced by Chinese and other ethnic groups for a number of reasons.

Chinese immigrants, perceived as 'an industrious race' and integral to the British enterprise, increased exponentially in number from 3,317 in I824 to 86,800 in I88I. This number was to double again in two decades by г9ог. The immigrant sub-ethnic Chinese groups of the Hokkien, Teochew or Cantonese, had settled earlier along the south-western side of the Singapore River, leaving other sub-ethnic Chinese groups to settle within the European town. At that time, the Europeans were beginning to move to the interiors of the island cleared by Chinese gambier farmers, dwell in bungalow houses within their plantations, and be distant from the city quarters and landscapes which were increasingly cramped by the mercantile and 'servant' populations.

In deference to the earlier settlement on the south-western side of the river, this later settlement at Middle Road was known colloquially by the overseas Chinese as 'Siao Bo' or 'Small Town' / 'Lesser Town' to its counterpart ' $\mathrm{Da} B \mathrm{~B}^{\prime}$ ' or 'Big Town/Greater Town' on the Singapore River. North Bridge Road and South Bridge Road, the two names of a continuous street that connected the two 'towns' across the river, was acknowledged as 'First Street' or 'Big Street'. The parallel roads north of North Bridge Road in Siao Bo were sequentially numbered, with Short Street near Mount Sophia designated as 'Seventh Street.

At Siao Bo, the distances of the minority Chinese enclaves away from the Singapore River also suggested the sequence of their settlement: first the Hainanese, then the Hakka, followed by the Hokchia, Foochow and Henghua groups. Together with the 'Malay' groups (that included the Sultan's families and retainers, the Arabs and the Bugis), Indian groups, and the Europeans who continued to reside in these areas, a truly multi-ethnic and multi-religious landscape was established northeast of the original settlement area around the Singapore River.

Of the various Chinese sub-ethnic groups that occupied Siao Bo, the Hainanese community was the largest, although they were almost always only marginally larger than the next group, the Hakkas. They must have been the first of the minority Chinese groups to settle in this area as their 
enclave is located immediately adjacent to the remaining European monuments of churches, army camps and Raffles Hotel. The enclave, which extended from the sea shore along Beach Road, westwards towards the interior of the island up to North Bridge Road, had a docking area. The three streets that run perpendicular to these two roads: Middle Road (colloquially Hainan First Street), Purvis Street (Hainan Second Street) and Seah Street (Hainan Third Street) were used by the Hainanese and other Chinese communities to conceive the space of that enclave.

The first Hainanese settlers in Singapore probably arrived in the I840s. As they were late on the scene and not located near the main godowns at the Singapore River, most of the early Hainanese settlers worked in the plantations or as sailors. Others were employed in the early service industries and operated provision shops, ship-chandling and remittance services, small hotels and coffee shops. However, it was the food and beverage businesses that would bring them most regional fame. For example, Wong Gong Chan mastered a rice dish served with steamed chicken, which was made famous by his apprentice Mok Fu Swee through his restaurant 'Swee Kee Chicken Rice' and later 're-exported' to Hainan Island and the East Asia as 'Hainanese Chicken Rice'. A gin tonic called 'The Singapore Sling' was first created in I9I5 by Ngiam Tong Boon, a bartender at the Raffles Hotel.

The first Hainanese association and clan temple building was built in I857, in three shophouses along nearby Malabar Street. In I879, the association / temple was moved to its present location along Beach Road. There is evidence that the Hainanese were a closely-knitted society through the compulsory social practices and treatment of new migrants as well as the welfare provided for the community through the services and facilities near Beach Road. Besides the main association complex on Beach Road, there were numerous clan associations along the three main streets, which were differentiated not just by the various districts or villages on Hainan Island, but also in combination with clan surnames. Most of its residents, however, had all but moved out of the enclave by the Ig 8 os to other parts of the island.

\section{The Island's Interiors and its Manipulated Landscapes}

As discussed above, the colonial conurbation that was Singapore Town was originally built on its southern edges between the two river mouths, but was eventually extended to the island's northern, eastern and western 'hinterlands.' Even after World War II, the Rochore River and Canal served as the main town's imagined northern boundary as the areas on its other bank were considered rural or countryside. We may sense the shape and speed of development by comparing early travel accounts. 
Five years after the founding of Singapore in I824, Munshi Abdullah needed eleven hours to reach an inland triad society living in the jungle. In I827, the Resident Councillor John Prince took five hours to walk from town to Bukit Timah (Blythe I969: 47-48; Buckley i984: I98). By the mid-Igth century, four main roads - Bukit Timah, Thomson, Serangoon and Changi - had intersected the island to reach its northern and eastern areas, but in I901 a bicycle journey from Cavenagh Road to the northern Kranji village still required an entire day (Brown 2007: 69-7I).

Among other uses, the plantation of crops was designated to land areas on the fringes of Singapore Town or further afield. Crops such as sugar, cotton, nutmeg, taro, rice and coffee were experimented with, while the numerous gambier and pepper plantations increased in number in the northern areas, financed by merchants in the Town. Within a decade or so, the gambier and pepper plantations had expanded to Johore across the straits, and subsequently the kangchu (river lord) system that was managed by mainly Teochews became formalised by the I83os with the Johore rulers. Such plantations in Singapore, which averaged 20 to 50 acres in size, employed shifting cultivation that led to the clearing of large tracts of land, denuding them of jungle trees and plants, as well as causing soil exhaustion (Jackson I968: 9-24; Pitt I987: I95-6; Trocki 2007: I04-IIO). Road construction to these plantations from the mid-Igth century onwards and the enforcement of land tenure and quit rents for these estates exacerbated the rapid formation of villages and plantations within the island's interior, creating peri-urban or semi-rural landscapes.

The plantation history of Singapore may be located within larger histories of resource acquisition and development projects elsewhere in the world. In the western hemisphere, colonial expansion beginning in the I6th century inscribed the world through the production of maps and ethnographic data, which systematically rationalised the land forms, peoples, as well as the flora and fauna encountered for the imperial cause. The Judeo-Christian belief in dictating and subordinating nature - founded on enlightenment ideals, imperial frameworks and scientific rationality - led to inscribing and controlling nature in these new 'frontier' lands. In the colonies, landscapes were reconfigured and demarcated for crop cultivation and mineral extraction to fuel colonial economies.

In Raffles' I822 town plan, the defensive advantages of a hill overlooking the indigenous settlement and anchorage areas of the Singapore River was recognised and he duly commissioned a hilltop fort for military surveillance while 'natives' were displaced from the plains. A contiguous artificial landscape strip in this area was established, stretching from the sea shore to the closest inland hill, comprising an open, manicured square protected by a battery wall and Fort Fullerton, the 
botanical and experimental gardens in between, and Fort Canning on Bukit Larangan (Forbidden Hill). The three man-made landscape components conspicuously displayed to the indigenous settlers how nature itself could be subjugated and manipulated to form a flattened field (the Padang), a garden for experimentation on trees and plants, and defensive arrangements on a hill. The construction of buildings on this artificial conurbation was highly selective, including a church, court house and government offices between the square and gardens, and the residence of its 'founder' on the hill.

From the Cantonment, the formal Padang space was inflected and copied elsewhere in Singapore. Colonial governments dispersed smallerscale open spaces in cities as part of infrastructural works for articulation and control of its various constituencies and enterprises. For example, a string of intermittent open areas were designated as greens or playgrounds that punctuated coastal settlements on both sides of the main Padang in Singapore. These became the secondary 'necklace' of cleared areas in congested and dense urban areas or ethnic enclaves that served as civic green or relief spaces for its urban populations.

Besides the colonial government, the locals were also responsible for creating some of the public spaces. Similar to the main colonial Padangs in layout and configuration, these served as corollary spaces that mimicked spatial power via arrangements of particular structures built around artificial fields to suggest socio-political hierarchy and alliance with colonial policies. Cheang Hong Lim, for example, donated three thousand dollars to convert land adjacent to the Central Police Station and the Police Court Building into a public field in 1876 for games and recreation. The location of the existing open space was by no means accidental, as it was placed strategically next to the Central Police Station, the wharves and godowns at the Singapore River, and the sub-ethnic 'Chinese' shophouse enclaves to its southwest.

As the island started its urban development, private estates were also formed with adjacent public gardens. In the mid-Igth century, Hoo Ah Kay was a notable businessman whose own estate comprising "avenues, fruit orchard, hanging gardens, Dutch walks, dwarf bamboos and orange trees" was occasionally opened to the public. He also donated a 23-hectare land plot near the Tanglin area to form the revived Botanic Gardens (Thomson I99I: 308). The Alkaff family developed the Alkaff Lake Gardens featuring verdant grounds, lakes and a Japanese garden and which was opened to the public for two decades from 1929. Elsewhere in the southwest, the Aw brothers of Aw Boon Haw and Aw Boon Par developed parts of their cliff-side estate in I937 to create the Haw Par Gardens, comprising mainly figurines from Chinese folklore set amidst a garden so that the overseas Chinese public could appreciate aspects of 'Chinese' culture. 


\section{Botany in literature, art and academic writing}

The early literary works in Singapore and Malaya for overseas Chinese, which were understandably Sinocentric, were influenced by the 'New Literature' that emerged around the time of the May Fourth Movement. In the I930s, a more vernacular form of poetry and prose emerged to express the consciousness of local subjects in Southeast Asia. The existence, intersection and negotiation of protagonists in political and sociocultural spheres took place in local places and settings, with climate and place adjustment as important backgrounds to the narratives. This was known as 'Nanyang Chinese literature' - a term that specifically referred to work from Singapore and peninsular Malaya, by then acknowledged as its mature production centres.

Themes such as coming to terms with colonial society, bearings in relation to China and the new locales, and inter-ethnic identities would figure prominently in such work. The development of such a genre in the 2oth century corresponded with the progressive clarification and adoption of subject identities as Nanyang or overseas Chinese instead of labour or soujourners in their host country, or indeed as erstwhile 'mainland Chinese.' Such consciousness could be found not only in literature but also in other creative forms during that time, such as everyday language which incorporated expressions influenced by the Malay patois.

Botany played a role in imagining the spaces of Nanyang Chinese in literature as metonymic or metaphoric connotations. For example, the rubber tree and the rubber plantation were leitmotifs for colonial occupation and exploitation, while the trope of Chinese or native females being raped in these plantations was used to symbolise the malfeasances of imperialism and capitalism (Wong 200I: I2I-I33). The tenor and feel of the tropics is eventually captured in the common literary expression 'jiao feng ye yu' [蕉风梛雨], which roughly translates as "winds through banana groves and rain-drenched coconut trees." Many plants and their fruits and products similarly became metaphors for contexts, settings and local conditions. Both 'banana' and 'coconut' became banners for literary supplements: Jiao Feng [蕉风] is a literary magazine started in 1955 and still in circulation, while Ye Lin [椰林] - a column in Singapore's earliest Chinese newspaper Lat Pao for literary works - ran for three years beginning in 1928.

As an example of literature employing tropical fruit tropes to suggest acclimatisation that continued even after World War II, we may examine the writings of Liu Yichang, a newspaper journalist originally based in Hong Kong. Liu lived in Singapore and Kuala Lumpur in the I960s and his articles and verses filled many newspaper columns and - eventually - also novels. Describing local scenes, Liu, who was seemingly self-Orientalist, waxed lyrical about observed kampong or rural life, in which imagery of 
tropical fruit and vegetation abounded alongside that of fighting fish, sunsets and Malay women, etc. In I972, Liu wrote the novella Intersection or 'Dui Dao,' [劉以它, 對倒], on which the Wong Kar-wai movie In the Mood for Love was later based. The work was seemingly semi-autobiographical, as the lead character in the novella and subsequent film was also a journalist in I960s Singapore. In both novella and film, the act of consuming fruit became synonymous with acclimatisation in Singapore:

It was the second week after his arrival in Singapore. He had gone into the outlying areas to visit a relative whose family managed a farm. He saw many durian trees there and heard stories about the fruit. They told him that the durian was the king of fruits: new immigrants who found a taste for it would never return to China.

The attenuation and acclimatisation of the local in creative realms through familiarisation or ingestion of fruits can also be found in art. One form that suggested attempts at coming to terms with the everyday was the medium of still life painting. In Norman Bryson's seminal work Looking at the Overlooked, Charles Sterling's distinctions between the two categories of 'megalography' and 'rhopography' were used to examine the relationships between depictions of 'grander' subject matter and those that were small or trivial. Bryson felt that the concept of rhopography was most applicable to still life painting because it extolled the familiar, feminine, personal and domestic in such work rather than the grand and heroic. The framed canvases through which the subjects are brought into focus and excluded from their surroundings by the artist are rhopographic modes for the viewer, making such landscapes feel legible, familiar, almost every-day.

Immigrant Chinese artists living in Singapore during the pre-war period began painting their new environments as a way of making sense of their new habitats and day-to-day life in the tropics. Painting tropical fruits became common practice for such artists in Southeast Asia, perhaps being construed as a way to domesticate life in the tropical climates far away from their former milieus in southern China or Europe. They make strange fruit familiar through depiction and inscription as well as eventual assimilation and ingestion. The act of painting still life is also perceived as a continuation of their artistic life in the west, albeit with substitute subjects, as fruits from the temperate climate were 'replaced' by local ones. All early-generation artists who arrived in Nanyang painted still life using tropical fruits. For example, we may observe how Georgette Chen and Liu Kang, artists now claimed as Singaporean, changed the subject matter of their still life paintings in their new setting. While in Paris, Chen painted oranges and apples in the I930s, and her subjects subsequently became rambutans, mangoesteens and other fruits in the 
I950s when she settled in Penang and then Singapore. Liu's early still life paintings inscribed the sunflowers, bread and wine bottles of I930s Paris, but this changed to bananas, rambutans and other local fruits after he returned to Singapore.

\section{Scholastic digests and the Han Rambutan Orchard}

This engagement with botany and flora by the overseas Chinese in Nanyang may also be detected in the publications of scholars. Up until that time, westerner-led academic scholarship was mainly published in museum journals as well as in the publications of the Malayan Branch of the Royal Asiatic Society, which was set up in Singapore in I877. The journal of the society, known by its acronym JMBRAS, aimed to document the land, including its flora and fauna as well as relevant Southeast Asian subjects such as archaeology, local cultures and indigenous peoples. During the inter-war years, the number of immigrant Chinese literati made it possible to establish a different academic space alongside the Royal Asiatic Society. The South Seas Society was set up in I940 by a group of academics and newspaper editors, partly to extend emergent scholarship on the study of Nanyang topics by Chinese researchers, and partly to counterpoint the Eurocentric scholarship found in JMBRAS. The society soon published its own journal, the Journal of the South Seas Society (or JSSS), with similar academic objectives to JMBRAS, but with the major difference of framing research through Nanyang lenses and identities.

While JMBRAS gave equal emphasis and coverage to flora and fauna in its published articles, JSSS gave prominence to flora at the expense of fauna. In fact fauna was noticeably absent and flora became a regular feature in the published essays. Vol. I No. I featured the mango, and in subsequent issues the segments featured the jackfruit, mangoesteen, papaya, Chinese fig, coconut, pineapple, $d u k u$, langsat, breadfruit, soursop, durian and the rambutan. The reason for this bias may be the presence of many contributors who were botanists such as Chang Li Chien [張禮千] and Han Wai Toon. The presence of flora but the absence of fauna may reflect the types of scholarship that interested the group, but perhaps also a focus on economic activities involving plant products.

Han Wai Toon [韩槐准, I892-I970] was a founder-member of the South Seas Society and, as discussed below, his rambutan orchard was a location where academic scholarship and literary pursuits intersected with botany. Han arrived in Singapore in I9I5 from Hainan Island in Southern China and, because he had only primary school education, worked as a rubber tapper and then at Medical Office (Shen Nong Medical Hall) dispensing chemicals and medicine. Through self-study, he became conversant with 
subjects such as chemistry, archaeology, historical geography, Taoist deities, ceramics, and botany, contributing numerous articles to scholastic journals including the JSSS. He wrote one book in I960: Ancient Export ware found in Nanyang [南洋遺留的中國古外銷陶瓷], and was the first to formalise authentication of Chinese porcelain and ceramics through chemical analyses of glazes (Hsü ig62).

Han's life-long pursuit of learning from chemistry blossomed during his 47-year residence in Singapore. While in Hainan, his family business involved the chemical dyeing of fabrics and cloth. This was intensified in I9I6, when the British colonial government auctioned the German-owned pharmaceutical practice known as 'Medical Office' in Singapore. Han was part of a group that bid successfully for the practice, subsequently named Shen Nong Medical Hall (see Figure 8.I). While he was employed there, he dedicated time to self-study: initially chemistry and developing photographs in the I920s. When his interest in ceramics was kindled in I934, he devised methods for tracing their provenance by identifying the inorganic glazes and dyes and the date when they were imported from China, a process supplemented by examining other aspects such as the firing skills, clay quality, fineness of the glazes, firing heat, application skills and type of motifs. During the Japanese Occupation, he and a business partner created the Hua Xia Chemical Supplies Company, based on these interests (Hsu I962: 70; Han I953: 329-331, Han I960: 2).

Figure 8.1 Shen Nong Medical Hall at Bras Basah Road, now demolished (courtesy of Koh Nguang How)

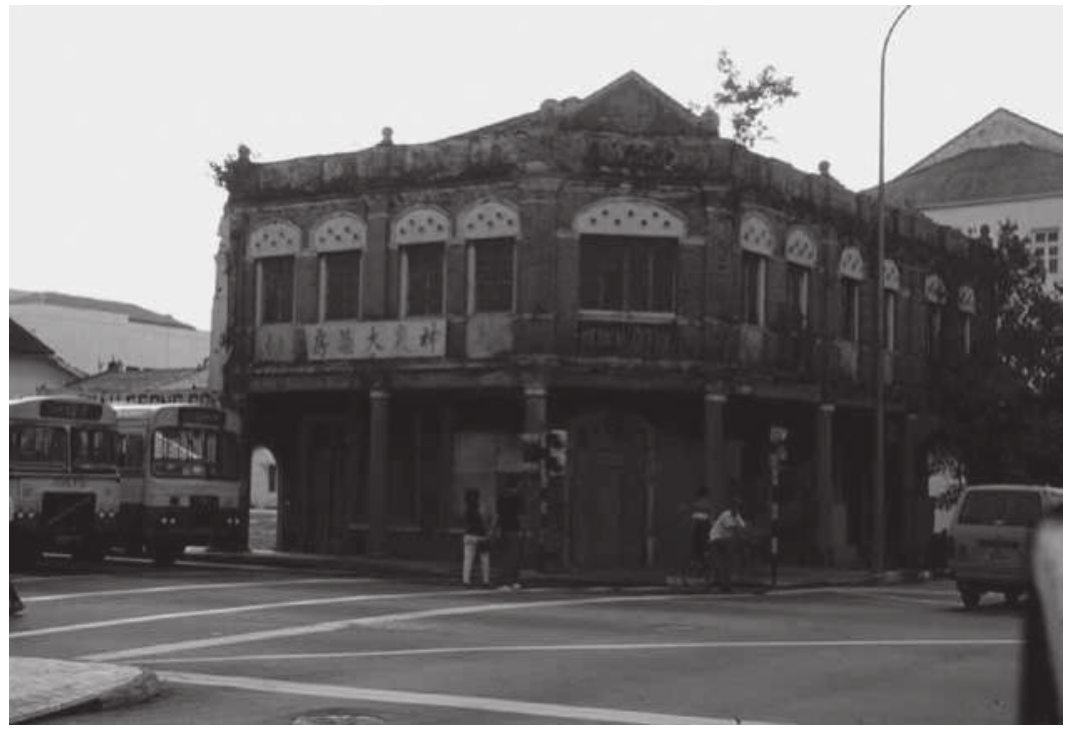




\section{The Han Rambutan Orchard}

Han eventually moved out of the city and his orchard at Upper Thomson Road and its chief crop of around 200 rambutan trees was a source of income. The orchard also became a meeting place for key members of the South Seas Society as well as other notable contemporary personalities, especially when rambutans were in season each May. In March I962, he returned to China on the invitation of Beijing's Palace Museum as a specialist consultant on export ware. He died there eight years later in I970. The orchard was sold to other owners in I962, converted into a chicken farm, and eventually evacuated when the state acquired the land.

While the orchard is now part of State Land, the space may be reconstructed from descriptions and accounts by the author and its visitors, as well as contemporary visual representations. In his I953 treatise on rambutan cultivation, Han recalled that he first purchased a piece of land in Mukim Sembawang in I933 to experiment with planting chillies, tobacco and rambutans, but had to vacate it as it was acquired for the construction of an airfield (Sembawang Air Base). In I936, he purchased two and a half acres of sloping land for seven hundred dollars in central Singapore (Mukim South Seletar) for his residence and for the specific purpose of agricultural experimentation. He was aware of the previous plantation histories of northern Singapore, firstly as gambier and pepper plantations and then as pineapple and rubber plantations. The growing of gambier and pepper would have depleted the humus and soil nutrients in those lands, but he determined that these could again be used for plantations by returning chemicals and nutrients to the soils (Han I953: 28-9).

He cleared the site of all vegetation and roots, paying particular attention to the removal of grasses such as lallang. These were all burnt along with the surface soil to create plant ash. After careful site allocation for habitat structures, tree-hole locations about 35 to 40 feet apart were dug and a combination of plant ash and fertiliser deposited into them before selected rambutan saplings were planted. These required constant attention in the first few years, in particular the drainage of excess rainwater, the use of fertilisers and protection against infestation by insects (Han I953: 39-4I). Descriptions of the resulting setting may be obtained from visitor accounts. Lian Shi Sheng notes:

Han Rambutan Orchard is situated on a slope. The rambutans are planted along the contoured terraces. Every tree has its immediate ground area raised on a mound of several inches high, with drainage maintained around them to allow for egress of excess water. Fallen flowers, leaves, branches and fruit are gathered beneath the tree for decomposition into fertiliser for the tree. The orchard is supplied 
by natural spring water channelled through a piping system. The spring water is clear and tasty, with no need for detoxification or filtering, and provides a year-round, readily-available water source for the orchard's uses. (Lian I955: I03)

The ideal site conditions are confirmed by Marco Hsü, who wrote: "The bathroom is constructed at the base of the slope, and spring water collected into a vat but excess water would flow out through drains. This arrangement is commodious and pleasant" (Hsü I962: 37). Han's orchard was visited by well-known literati and scholars, who consumed the fruit and left inscriptions or images (see Figure 8.2). Marco Hsü recounted that the Chinese artist Xu Bei Hong [徐悲鴻] had a Chinese painting of rambutans dedicated to Han, and fruit from that orchard was also used in a still life painting by Liu Sian Teck [劉先德]. Han appreciated an oil painting by Liu Kang [劉抗] with the background of Han's repository of books and artefacts, shrine and its adjacent areas. In the work, Han is shown seated at a stone table, while two people are seen eating rambutans behind him at another table. The imagined connection between the two locations of Southern China and Singapore may be observed in another still-life painting of rambutans by Huang Pao Fang [黄葆芳], who frequented Han's orchard. Besides the rambutans in the painting possibly products of the orchard itself - the inscribed captions, such as "Travelling three thousand $l i$ just to taste rambutans in May" are quoted from the celebrated writer Yu Dafu [郁達夫] who was known to have been a visitor as well. The three thousand $l i$ would mark the putative diasporic distance or proximity between China and Singapore.

Currently the best known spatial representation of the orchard is a work by the artist Lim $\mathrm{Mu}$ Hue, entitled "Han Rambutan Orchard" (Hsü I962: 37). This was commissioned by many of Han's friends, who wanted to commemorate their time at the orchard when he returned to China in 1962. Apart from his lengthy I953 treatise published in the JSSS, the work was also the only visual illustration of Han's methods of

Figure 8.2 Han Wai Toon, Marco Hsü and guests at the Han Rambutan Orchard (image courtesy of the estate of Marco Hsï)

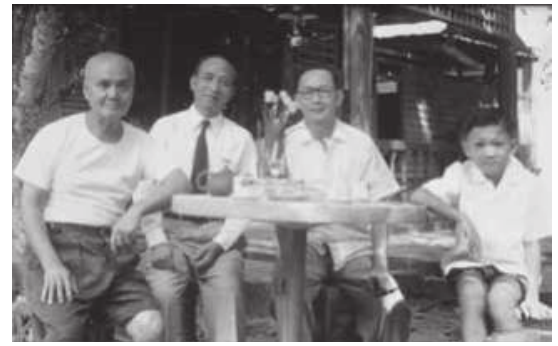


ideal rambutan cultivation. Aspects of tree spacing, the articulation of landscape to allow for natural irrigation, and the placement of human habitats within it can all be seen in the painting, along with the simple structures made of timber and corrugated aluminium panels that made up his house, a study and a shed containing artefacts.

\section{Lim Mu Hue and Singapore's changing landscapes}

Lim Mu Hue [林木化, 1936-2008], who was born in inter-war Singapore, graduated from the Nanyang Academy of Fine Arts (NAFA) in I955. He taught at the academy until I969, and for the next five years served as an editor for the Chinese newspaper, Nanyang Siang Pau, before becoming a full-time artist. Although he had graduated with a diploma in Western Painting from NAFA, Lim was conversant with various artistic mediums including oil, ink pastel, and charcoal and became well-known for his woodcut prints and satirical cartoons. Beginning in 1956 , his art works were exhibited in countless solo and group exhibitions. His essays and commentaries were also recorded in print, in newspapers and several publications.

It should be noted that the period of Lim's main production of art from the I950s onwards coincided with the rapid reconfiguration and transformation of Singapore's landscapes. Lim was educated in Chinese-medium schools and then at the pioneer art school in Southeast Asia administered and staffed by diasporic Chinese. He considered the island his home and painted its landscapes incessantly, recording places such as Tanjong Rhu, Changi, Bedok, Jurong, Bukit Pasoh, as well as the Telok Blangah area where he eventually settled. In Lim's woodcuts and thematic paintings, one can observe his attention to the details and exigencies of life. Paintings of boatyards, kampongs, hill areas, and quarries give his oeuvre a documentary function as landscape portraits against the grain of Singapore's instrumental physical and rapid development. In contrast, his other works depict landscape on a more expansive scale, capturing them on huge canvasses as if observed from a bird's eye view.

As part of the emerging local Chinese-educated literati, Lim was often invited to Han's rambutan orchard $81 / 2$ miles along Upper Thomson Road together with art historian Marco Hsü [許鐘祜 or 瑪戈, Ma Ge]. Hsü urged Lim to consider seriously about painting a commemorative work of the plantation around I96I, a year before Han's departure from Singapore. Lim had already started sketching parts of the orchard and, with the encouragement of Hsü and others, he meticulously detailed the site in charcoal studies with added purpose (see Figure 8.3). Three preparatory drawings were made around I964, two in ink and one in pencil, stitching together the entire site composed from all of his sketches into 
Figure 8.3 Detailed sketch of the orchard by Lim Mu Hue (courtesy of the estate of Lim Mu Hue)

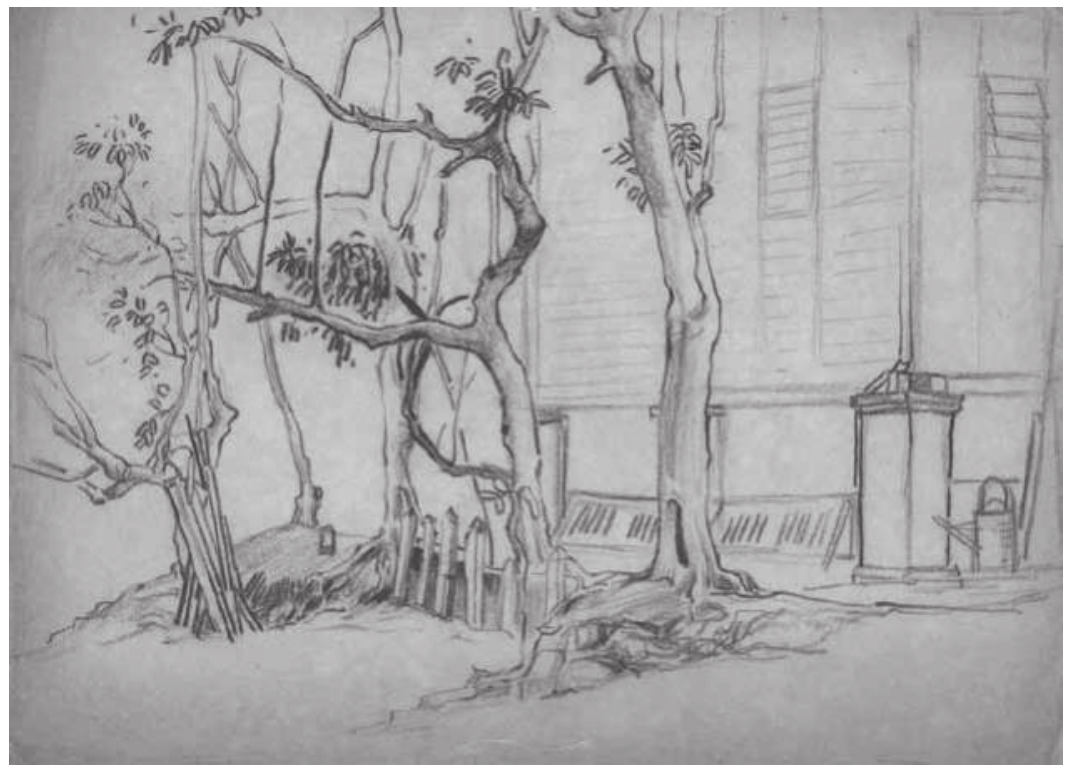

one sweeping, panoramic construction. The final I964 work in Chinese ink on sepia rice paper [xuan paper, 宣紙] measured six by four feet. The viewpoint is located as if in mid-air at a high vantage point above the orchard, looking down at its entirety on the ground. However, the neighbouring areas of the orchard are not inscribed, accentuating focus on that space. Hsü subsequently noted that Lim had taken the liberty to remove some trees to emphasise the visibility of several key areas of the painting, but the depiction is otherwise accurate (Hsü I967: 4).

In the final version, Lim put himself inside the painting, standing next to and conversing with Han in front of his house, with before them a large rattan basket brimming over with the harvested red fruit. Thirteen other human figures are interspersed at various locations in the painting, singly or in groups. These were Han's family members and other visitors to the orchard (see Figure 8.4). The ground appears to have been altered and sculpted by human hands, as a gentle slope from background (Old Upper Thomson Road) to foreground (Upper Thomson Road). Several built structures that formed the Han family abode and kitchen, repository and study, a Tua Pek Kong shrine as well as a toilet and outdoor furniture, are placed along a horizontal line in the middle ground. The remaining middle and foreground of the painting is filled mainly with well-spaced rambutan trees, their roots and relative positions articulated as if tracing curved and diagonal lines along the contours of the landscape. The trees 


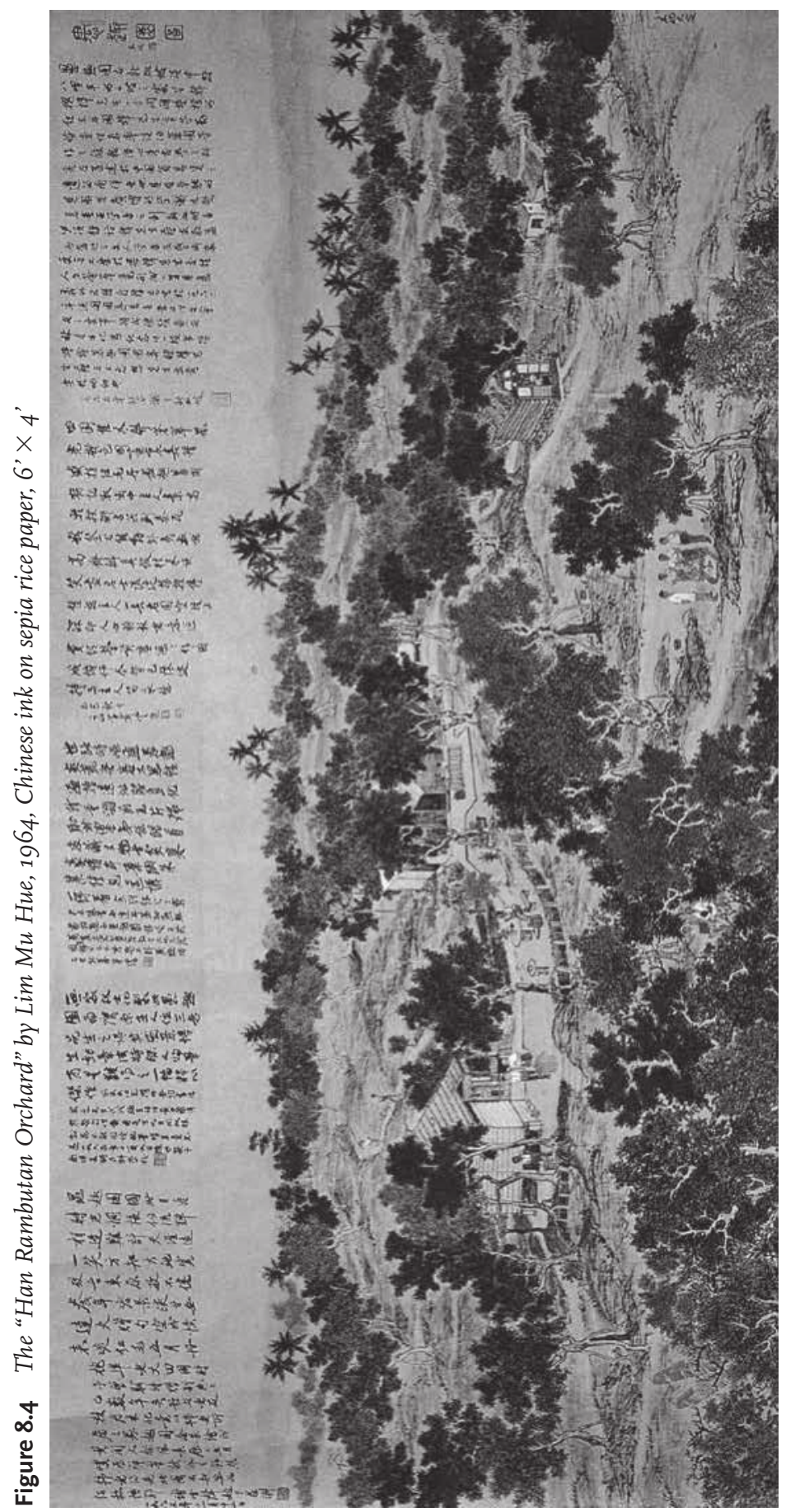


are each raised on a mound of earth, with spots and clusters of red in the trees' foliage indicating that the rambutans are in season, perhaps during the month of May. Other trees and shrubs such as coconut and banana trees are planted amidst the rambutan trees.

At the top band of the painting, six Chinese captions by different authors can be found, to be red from right to left. Lim inscribed the title of the painting, Han Rambutan Orchard [愚趣園圖], with a signature and Chinese seal. In prose and in verse, five other captions follow Lim in the following sequence: Marco Hsü, Wong Jai Ling, Chen Chong Swee, Tan Tee Chie, and Seah Yoon Hsia (translated). Wong, Chen and Tan - artists and colleagues of Lim at NAFA - describe and praise the work of Han and the space he had created. The commemorative nature of the painting is also noted in some of the captions. The dates are inscribed as I965 and the location is identified as Singapore, signed by the various writers and each imprinted with their personal seals after their signature. In using such a painting format, Lim had invoked the tradition of Chinese landscape painting to imagine and inscribe the space of the rambutan orchard. The captions, signatures and seals are conventions of Chinese literati, even if they now reside and work in Singapore.

\section{Living in the 'rural North', imagining China's 'South'}

Han's choice of living within and creating a hybrid plantation space may be interpreted in many ways. The most obvious would be to see the garden as a synecdoche or a ' $y a$ ji' (雅集, commodious abode), a formalised spatial type in Chinese landscape history. This is a site set amidst landscape where literati would gather for seasonal meetings for communal appreciation of poetry, painting, music, relics and artefacts, often accompanied by consumption of drink and food. This is a space for scholar gentry, exiled politicians or court officials, who may transpose their scholarly gaze and identities onto the landscapes into which they were cast. But such a space need not only be a retreat for humble scholars. As Craig Clunas has pointed out, there were also Chinese gardens in Suzhou during the Ming Dynasty planted with cash crops or fruits, and such gardens were also economic spaces despite their apparently verdant and poetic settings (Clunas I996).

For precedents of the $y a$ ji, we can perhaps best examine the 1087 painting known as the "Elegant Gathering in the Western Garden" [李公麟, 西園雅集圖] by Li Kung-Lin, which depicted an assembly of sixteen notables in the Western Garden belonging to Wang Shen in Kaifeng. These included Su Shih [蘇軾 or 蘇東坡 (Su Dongpo)], his brother and the artist himself, with the group amusing themselves with poetry, painting, music and literary exposition. The painting, the activities depicted and the setting have since achieved such prominence that it 
is now symbolic of literati activities and locations, even if other contemporary scholars have demonstrated that such a meeting with its protagonists never actually took place (Laing I968: 426-7). Such gatherings or activities within landscape settings would, however, have been common occurrences, as can be read in other texts such as poetry and treatises. For example, Li Shih-chen the Ming dynasty physician who wrote Compendium of Materia Medica [李時珍, 本草綱目] noted that lychee trees were the sites beneath which folks from all walks of life would gather during the fifth and sixth months of the lunar calendar, to savour ripe fruits and to appreciate the trees (Li 1994: I797).

The citation of the Song Dynasty luminary Su Shih and the lychee fruit are important to the construction of the notational $y a j i$ and subsequently as invoked identities by the literati who settled in Singapore. Su was an influential poet and essayist in Song Dynasty China. Formerly the brightest of the Northern Song administration, reforms led to multiple demotions and exile to the south in Lingnan (Huichou), 70 miles east of Canton in Guangdong province, and eventually to the southernmost point of China, on Hainan Island. This citation of Su and the lychee fruit was noted by visitors to the orchard, including Hsu Yun Tsiao (Hsu I962: 7I, Hsu I970: 38, and Han 2008: 332). Han himself had described his orchard in the following manner, seemingly along the lines of the ' $y a$ ji':

After five years, the trees would provide much shade and fruit. When they ripen, the red rambutans would burst through the green foliage to create an alluring image of nature. One can indulge in such a scene till the sun returns west and the clouds dip past the hills. Wandering through the orchard, one could reach for the fruit and squat beneath the trees, and read Han Yu's 'Prelude to Seeing Li Yuan off to Pangu' or recite Su Shih's 'Eating Lychees.' This would really 'leave a fragrance between the teeth and relax the mind.' (Han I953: 3I)

The second reason for Han's rural self-identity was perhaps to set himself apart from downtown Singapore, which was largely the space of other successful Chinese sub-ethnic groups associated with colonial enterprise. Han's personal transformation from a labourer into a respected scholar was uncommon in colonial Singapore and even more so because of his insistence on the use of the Chinese and Malay languages. Like the Ming dynasty gardens, his move to the suburban plantation could offer a reclusive space to continue his scholastic practices and 'cultivations,' without sacrificing the means of economic sustenance through sales of his rambutans and other fruits. His juicy and well-grown rambutans fetched the best market prices in town each May and people who knew where the plantation was drove there to purchase the choice selections. 
Han's movements across the island during his time in Singapore may, however, also be connected to the history of Hainanese diasporic spaces themselves. By I885, the Hainanese were employed in pepper and gambier plantations in the Nee Soon area at Kampong Heng Leh Peh and other areas, besides occupying the urban Hainanese enclave described earlier. The Shen Nong Medical Hall where Han learned western chemistry is situated along Bras Basah Road at the edge of the Hainanese enclave, but he later joined the ranks of Hainanese who moved to settle in other parts to the north of the city. Han's orchard is sited near Lorong Pelita, the location of a large Hainanese enclave of chicken and pig farms, but physical vestiges of this area as a settlement have since vanished (Wong I987: 87-90).

\section{Grafting plants, locales and identities}

Lim's painting of the orchard illustrated the innovative grafting method that Han had adapted for fruit trees. This was an improvised form of what is known as Inarch grafting in which roots and stems of different tree species are planted adjacently and grafted together after a year to eventually form a single tree out of several tree roots. While in the early life of the tree, such a system of multiple stems had the advantage of providing structural support for the weak saplings, when fully grown the multi-hybridised tree produced up to five different types of rambutans, each with differing characteristics and tastes on a single tree (see Figure 8.5). The various hybrids on the resultant tree are genetically strengthened and 'weaker' traits compensated if they are then regrafted and replanted elsewhere (Han I953: 33).

The choice of fruit and its hybridisation in his orchard may also be related to Han's self-construction of social and cultural identities as Southern Chinese. It must be pointed out that rambutans belong to the Sapindaceae family, of which there are four principal fruits: the

Figure 8.5 A detail of Lim's painting showing Han's Inarch grafting method

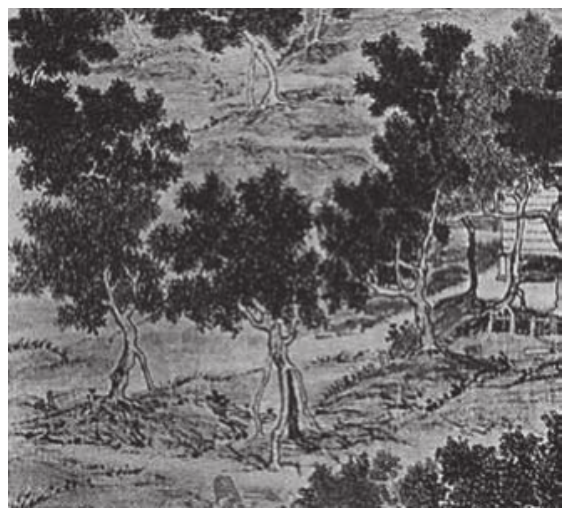


lychee, longan, pulasan and rambutan. While the longan and lychee are found mainly in subtropical regions, the pulasan and rambutan thrive only in the tropics (Groff I92I: 6). Early Sinic records of the rambutan fruit in Nanyang in fact mistakenly describe it as a form of the lychee fruit. Ma Huan's Ming Dynasty work The Overall Survey of the Ocean's Shores [馬歡, 瀛涯勝覽] called it the ‘wild litchi' and in Wu Qi-jun's I848 work A Study of Plant Names and their Pictures [吴其浚, 植物名實圖考], they were referred to as 'hairy lychees.' Texts such as Wang Da-Hai's I79I Anecdotes of Oceanic Islands [王大海, 海島逸志] liken both the colour and taste of rambutans to those of lychees (Ma I970: II2, Yao I984: I58I59).

By his own admission, in his celebrated rambutan treatise, Han revealed that the choice of rambutans for his orchard was twofold. The first was again connected with his chemistry studies, as he was curious whether ammonium sulphate could be used as a fertiliser, and secondly because of the connection to lychees from Southern China. For him, this was a way to remember his erstwhile sub-tropical origins through the fruit's surrogate or transferred identity. Han called this act a "foolish indulgence" and named his abode "the orchard of foolish indulgences" in Mandarin:

... I purchased two acres of land in Mukim South Seletar for residence as well as to plant rambutans: the Nanyang specialty which is from the same family and genus as the lychee. The fruit of good species of rambutans are not only delicious and delectable; when ripened they are such as lychees from the home country that we may appreciate and which serve to appease the soul. This is a primary pleasure a foolish person may pursue, and hence the orchard is named for my 'foolish indulgences.' (Han I953: 82)

The invocation of the lychee in this case is not to adorn/construct a Chinese identity, but specifically one of Southern China. The lychee is a sub-tropical evergreen that is found only in those regions and unable to survive in the colder climates of the temperate north. Of the many tales of northern China's fascination with the fruit is that of Yang Guifei: a concubine so besotted with its aesthetic and curative properties that fresh lychees were ordered by royal decree to be brought from the south to the northern palace via relay stations for her consumption, at the cost of many lives of humans and horses, and at great court expense.

We may examine other textual productions by the orchard's visitors to further discuss this identity connection Nanyang where rambutans are found between lychees and rambutans. In a poem by Hsu Yun Ts'iao, chief editor of JSSS, entitled Rhymes on Ten Famous Tropical Fruits Rambutan, Hsu proclaimed that "Lychees and rambutans belong to the same family, and Lingnan's acclaim as the place for lychees should be shared with Nanyang where rambutans are found” [韶荔抗禮本同科... 
不讓岭南獨頌坡]. Lingnan was a part of Southern China, and also a textual reference to the area's most famous soujourner Su Shih, who was eventually exiled to Lingnan (Huichou) and Hainan Island. There, Su planted fruit tress of the lychee, orange and pomelo in his garden and wrote his most famous lychee poem Eating Lychees 「食荔枝」 that concluded with the two lines: "Eating 300 lychees a day, I can be a resident of Lingnan” [日啖荔枝三百顆, 不辭長作嶺南人].

Back in the rambutan orchard, the overseas Chinese literati had a field day contemplating these lines and performing textual grafting of fruits, elements and places as if these were interchangeable. Huang Baofang substituted 'lychee' for 'rambutan' and 'Lingnan' for 'Singapore' in Su's poem to read "Eating three hundred rambutans a day, I can be a person living in Singapore” [日啖毛丹三百顆, 不辞長作星洲人]. The renowned Chinese artist $\mathrm{Xu}$ Bei Hong, who was a close friend of Han, wrote the following dedication in a painting: "Eating a hundred rambutans a day, I don't mind residing in the tropics” [日啖红毛丹百顆, 不妨長作炎方人]. Writing in I951, Lian Shi Sheng remarked how a Medan species of the rambutan grown in Han's orchard produced a small seed within, its flesh akin to the lychees from Fuzhou (Lian I951: IO2). Thus, quite apart from textually substituting lychees with rambutans and Lingnan with Singapore as textual and spatial 'grafts,' the orchard may have actually botanically hybridised the rambutan into a simulated likeness of the lychee fruit.

\section{Conclusion}

In this chapter, I discuss the construction of 2 oth century Chinese diaspora spaces in Singapore by delineating the urban enclave of the minority Hainanese sub-ethnic group and contrasting it with a space for literati created by one member of the immigrant Hainanese. I suggest that the Han Rambutan Orchard is a hybrid type of space that is non-urban and that its spatial form is unlike the plantations of the overseas Chinese or colonial British planters. I argue that the space is a textual chronotope that transferred imaginations of Chinese literary time and space, as well as the Chinese garden landscapes associated with that time and space. Once created, it availed a space for acclimatisation and imagination for its users to the tropics and to life in Singapore. Particular overseas Chinese identities in Southeast Asia were also cultivated through the functions of this space as organised by its owner, Han Wai Toon.

I argue that engagements with tropical botany and botanical products played a significant role in this acclimatisation through their inscriptions in art, literature and academic scholarship. With their familiarisation and eventual ingestion, the 'tropics' are 'consumed,' internalised and made routine and quotidian. The creation of the Han Rambutan Orchard and 
rambutan tree cultivation connected the spaces of Southern China and Singapore for the diasporic Chinese literati and intellectuals in Southeast Asia. Within this space, the rambutan (a tropical fruit) is considered to be a botanical substitute for the lychee (a sub-tropical fruit of the same family), but also as an extant literary and locational connection to references associated with the fruit. Through the historical figure and poems of $\mathrm{Su}$ Shih, the imaginations of southern exile of the literati community were re-enacted by Han and his 'elegant gathering' of friends and acquaintances, albeit in an area 'further south' than Hainan Island.

Han's eventual return to China in I962, despite the length of his soujourn in Nanyang, reflected the latent call for his generation of immigrants to finally connect with the land of their birth. Besides his botanical and literary work, his eventual study of export ware permitted a connective bond with objects produced in China and provided a means for his 'return.' The departure of Han back to China occurred when self-governance had been achieved in Singapore in I959, but with the imminent prospect of a merger with Malaysia that would take place in I963. Development was also encroaching on northern Singapore where he lived and worked. A new main road - Upper Thomson Road - was built next to his orchard and the Singapore Grand Prix was established in I96I with a circuit that encircled his estate. This event brought large crowds and noisy vehicles to the otherwise tranquil surroundings of Lower Seletar one year before his departure.

In contrast to Han, we may observe the literary and art practices of Lim $\mathrm{Mu}$ Hue as those of Chinese literati born on the island who harboured less imagined connections with China, despite being educated and immersed in its cultures and traditions in 'the South Seas.' Lim painted Singapore landscapes throughout his life, wrote essays and created cartoons that dealt with life and situations on the island, and passed away there in 2008 . His Han Rambutan Garden painting used the formats and traditions of Chinese painting, but the treatment of its landscape spaces, elements and people are inflected by his ability to work in other art mediums, including non-Chinese ones. From I96I to I964, Lim reconstructed an important part of Singapore's intellectual history and botanical significance as a commemorative painting. This has permitted us to study the different generations of overseas Chinese communities, including Han and Lim, and to explore their complex self and group identities. 


\section{Note}

I The author would like to thank Mr. T.K. Sabapathy for the comments and suggestions he provided during the writing of this paper, the late Mr. Lim Mu Hue for first showing me an image of his painting entitled Han Rambutan Garden, and all friends who have contributed in one way or another to this paper's eventual form. 


\title{
9 The Global Effects of an Ethnic Riot: Singapore, 1950-1954
}

\author{
Syed Muhd Khairudin Aljunied
}

\section{Introduction}

One of the major advances in scholarly writings about Southeast Asia in the past few decades has taken place in the study of ethnic riots (under the rubric of nation-state formation). From this perspective, episodes of mass violence involving two or more distinct ethnic groups are said to have been caused primarily by the ideological, structural, psychological, economic and social strains faced by local communities in their struggles to preserve their cultural traditions and civil rights amidst regime transitions and rapid political change. While acknowledging the interplay of regional and global processes as precipitants of ethnic riots, scholars subscribing to such a paradigm have tended to give primacy to the roles of endogenous forces in the perpetuation of conflicts that were already brewing in Southeast Asian societies.

Despite being extensive and no less impactful, one visible shortcoming of this prevailing strand of scholarship has been a strong emphasis on searching for causes and motives, much to the neglect of the larger implications and effects of ethnic riots. The aftermath of ethnic riots is rarely if ever discussed, let alone examined systematically, but such studies are mainly concerned with post-conflict reconstruction, including localised attempts at reconciling feuding groups, state restoration of ravaged societies and the implementation of preventive measures through the recommendations made by truth commissions. The picture that emerges from all of such studies of the aftermath of ethnic riots is that such conflicts have had little impact beyond their restricted settings. Put differently, the study of the aftermath of ethnic riots in Southeast Asia has been provincialised, relegated to a localised world, and thus excluded from the wider connections and developments in the region and beyond. ${ }^{1}$

This essay takes a different approach. It seeks to provide an illustrative example of the ways in which the study of ethnic riots and - by implication, Singapore's past - could be reframed by initiating a shift away from the analysis of the causes, processes and conditions that led to the outbreak of mass violence towards the regional and global responses encountered and the attendant effects in the aftermath. At the centre of my analysis is the case of an ethnic riot that broke out 
in colonial Singapore, more commonly known as the Maria Hertogh riots. This involved a legal tussle over a Dutch girl, who, after having been separated for more than seven years from her Dutch-Catholic parents and raised as a Muslim in a Malay family, faced a ruling by a British judge that she should be returned to the Netherlands. The riots that broke out from II to I3 December I950, which pitched Muslims in Singapore against Eurasians and Europeans on the island, have generated innumerable articles and books with varied interpretations and revisionist conclusions (Conceicao 2007; Firdaus I985; Haja Maideen I989; Hughes 1980; Nordin 2005; Ramlah 2004 and Stockwell I986). Nevertheless, like most studies of riots, pogroms and disorders in other parts of Southeast Asia, previous analyses of the Maria Hertogh riots were mainly concerned with narrating the events that up led to the outbreak of violence and the measures taken to halt it. The regional and global effects of the riots have received much less attention. There has been no comprehensive scrutiny of the variety of strategies that were employed by colonial states to deal with the various forms of resistance, the collaboration of local elites and the impact of these processes on local communities following the riots.

The perspective that I am offering here does not in any way imply that all episodes of ethnic riots in colonial and postcolonial Southeast Asia have had regional and global ramifications. On the contrary, this chapter aims to offer a new perspective that will enable historians to reconceptualise riots and other forms of collective violence beyond the confines of the locality and to incorporate regional and global processes into the historical narrative. Prasenjit Duara has described this method of analyzing the history of a country or region as 'outside-in'. In his view, it is only when the local, the regional and the global are integrated and placed together within a singular analytical frame that we can grasp the meaning of events and ideas in their entirety (Duara 2009, I). This is especially true in the colonies during the post-World War Two period. Episodes of mass violence and anti-colonial struggles seldom escape the watchful eye of the worldwide media and non-governmental organisations that were able to transcend the constraints imposed by colonial regimes.

As a corollary to this, I find it useful to integrate Duara's insights with those of Tony Ballantyne's in my scrutiny of the aftermath of the Maria Hertogh riots in colonial Singapore. Drawing on the influential work of Eric R. Wolf, Ballantyne conceives the colonial empires as 'bundles of relationships' that were contingent on a composite interplay of local, regional and global human interactions and exchanges. It follows then that the British Empire is to be conceived as a complex web "consisting of horizontal filaments that run among various colonies in addition to vertical connections between the metropole and individual colonies" 
(Ballantyne 2003, II2-II3; See also, Wolf I982, 3-23). Although much both of Duara's and Ballantyne's discussions is confined to South and East Asian pasts, their insights could well be extended to understanding historical change in colonial Southeast Asia. By employing 'outside in', 'complex web' and 'bundles of relationships' as lenses to analyze the aftermath of the Maria Hertogh riots, I will demonstrate that both the horizontal filaments and the vertical connections of the British Empire proved vital in ensuring that there were swift reactions to the protests of the various parties that were concerned with the riots and the legal controversy. Paradoxically, in an age of decolonisation, the communication links and political networks established by the British also functioned as avenues of resistance and dissent for politicians in newly-independent countries, as well as anti-colonial activists and news agencies in the colonies and in Britain itself. Some parallels could be drawn here with the postcolonial era which saw the advent of what many theorists has termed as the 'global information society'. Knowledge and news have become easily available since the internet and disseminated in a more rapid pace than ever before, thereby challenging the sovereignty of states and governments.

This chapter begins with an exploration of the regional responses to this outbreak of mass violence. The word 'regional' here refers to cities and populations that reside in the areas closest to the island of Singapore, including the Malayan Peninsula and Indonesia. By virtue of geographical proximity and strong social bonds through ties of kinship as well as extra-familial relationships, the response to the riots was instantaneous and seemingly more dangerous in these places, when compared with other areas where Muslims were equally well informed about the events as they unfolded. I will then review the different types of responses from various communities, including protests, appeals and declarations from Muslims and non-Muslims in the Netherlands, Britain, Pakistan and Saudi Arabia. The final section of the chapter will analyse how the British dealt with a variety of regional and global responses. Special emphasis will be given to the multifaceted strategies employed by the colonial administration in England and the colonies for the purpose of repairing their tarnished image and recovering their political legitimacy and public support, both at home and abroad.

\section{Perils emanating from Southeast Asia}

The most complex and yet spontaneous responses to the Maria Hertogh riots came from Muslims in mainland Malaya, South Thailand and Indonesia. This is unsurprising, given the long historical and familial ties between Muslim communities in Singapore and their brethren in 
other parts of Southeast Asia. Migratory flows in and out of Singapore following the re-establishment of British rule on the island had reinvigorated communicative networks and social ties that were broken during the Japanese occupation from I942 to I945. This, along with the continued lurid coverage of the Maria Hertogh case by Malay-Indonesian newspapers such as Indonesia Raya, Utusan Melayu and Melayu Raya had intensified Muslim disaffection and contributed, in some measure, to the heightening of political consciousness and social activism within the vibrant local population. Numerous editorial commentaries and reports emphasised the fact that Maria Hertogh had been deprived of the care of her foster mother and was coerced into accepting the Catholic faith. The prominence given to Maria Hertogh's fervent devotion to Islam (she had been renamed 'Nadra', meaning Special), together with her purported proficiency in the Malay vernacular rather than Dutch, was enough to convince Muslims in the region that the decision made by the British court to return her to the custody of her parents was a product of colonial bias towards Islam and Muslims in general (Melayu Raya, 2I December I950). ${ }^{2}$

Among the various groups in mainland Malaya who were greatly affected by the events that unfolded in Singapore were the Muslim members of the security forces. They were reported to be troubled by their commitment to defend the colonial state against the communists after having witnessed what they regarded as the unfair treatment of their co-religionists in the realm of colonial laws. The communists, predictably, quickly capitalised on this state of affairs by attempting to widen the split between the colonial state and the uniformed security personnel. After more than two years of failed ideological campaigns after the declaration of the Malayan Emergency in I948, the communists had finally found a persuasive propaganda tool to claim that British policies were unfair to Muslims. A day after the quelling of the riots in Singapore, a group of communists distributed two propaganda pamphlets in Romanised Malay, English and Chinese, highlighting jaundiced British attitudes towards the local population. They called on Muslim policemen and soldiers to transform the Maria Hertogh case from a mere religious struggle into a political one, led by a communist party that was capable of fighting for the people. Two weeks later, an English edition of the communist Freedom News was circulated, with an article entitled "Develop the fight against the Nadra decision into a wide struggle against the British Imperialists!" Posters calling for all races in Singapore to join together and resist the colonialists were displayed in public places in Singapore. Muslims and members of other communities were encouraged to join the 'Anti-British Liberation Army' in an armed struggle against colonialism. Such propaganda quickly spread across various parts of the Malayan Peninsula in a drive to incite Muslim rage. ${ }^{3}$ 
In Kelantan, the voices that appealed for moderation were drowned out by a rapid escalation of anti-British feelings. Such sentiments were amplified by two radical groups. The first was a band of twenty young men in Kota Bahru who adopted the title Nikat (a Malay word which means 'to engage in acts regardless of expected consequences'). Commanded by Ismail bin Mohamed Salleh, a clerk at a local hospital, the group's objective was to kill selected Europeans who were involved in the Maria Hertogh case. Its supporters and sympathisers numbered eighty in all, one of the most prominent being Mustapha bin Mahmood, who was the brother-in-law of the Chief Minister of Kelantan. Another radical group originated from a small school outside Kota Bahru. Consisting largely of religious teachers and students who were financed by influential families within the state hierarchy, the main aim of this collective was to indoctrinate Malays in the nearby villages against the British, who they regarded as hostile to Islam. Although none of these groups actually initiated any violent acts, their aggressive outlook revealed the extent to which the Maria Hertogh case had radicalised some quarters within the Muslim community in Malaya. The same degree of hostility towards the British was observed in Johore. Members of invulnerable cults, triads and militant groups in this neighbouring Malay state were reported to have planned to enter Singapore and carry out violent campaigns on the island. ${ }^{4}$

Muslims in Penang and prominent members of the Malay aristocratic class disagreed with the radicals and came to the aid of the British by striving to allay suspicions and unhappiness among those who had been informed of the riots. In a widely-publicised declaration, Muslim elites in Penang appealed to their brethren in Malaya and Singapore to work towards the re-establishment of peace and harmony with other races. At the same time, they registered their despair over the arrest of Muslim elites in Singapore and contributed large amounts of money to the Singapore Muslim League for their legal expenses. Similarly, Sultan Abu Bakar of Pahang revealed his plans to organise visits and discussions with several influential Muslims in Singapore. He hoped to encourage patience and self-restraint, as well as to advocate that the Maria Hertogh legal controversy should not be viewed as a religious issue. ${ }^{5}$ Sultan Abu Bakar was not the only Malay ruler who worked to improve relations between Muslims and non-Muslims. In March I952, the Sultan of Kedah decided to ban the screening and sale of a Hollywood film, David and Bathsheba, on the grounds that it "will create a religious controversy in the country" (Straits Budget, I $3^{\text {th }}$ March 1952). Since its release in January I952, the film had incited protests from Muslims in Singapore and Malaya who had planned to use it as a catalyst to re-ignite Muslim interest in the Maria Hertogh case. The main lines of objection voiced by the protesters were that the film's portrayal of King David committing adultery 
was contrary to Quranic teachings, and that the screening of the film was a product of British insensitivity and indifference towards Islam. ${ }^{6}$

The fifty-five-year-old President of the United Malay Nationalist Organisation (UMNO), Dato Onn bin Jaafar, went beyond assuaging Muslim rage and such political moves contributed to a decline in popular support for him and the emergence of widespread criticism of his leadership. In a highly publicised statement, he remarked that "[n]ot only the administration but 80 per cent of Singapore residents lost confidence in us because of the action of a comparative few." He advised UMNO members to steer clear of destructive acts, which would disrupt the notable efforts of Malays in governmental agencies. The peace and freedom of the country must be upheld and full support should be given to the British government in upholding peace and harmony in the country (Majlis, 26 February I95I; The Straits Times, 26 February I95I). Both Muslim and non-Muslim elites in Malaya voiced their fundamental dissent with Dato Onn's negative portrayal of Malays. A joint statement by the Malayan Chinese Association (MCA), the Singapore Muslim League, the Hindu Board, and the Straits Chinese British Association (SCBA) argued that it was erroneous to place the entire blame on all members of the Malay community for the wrongdoings of opportunists and irresponsible people in the course of the riots. In fact, a majority of Malays in Singapore had displayed great courage by sheltering Europeans and Eurasians who might otherwise have been mauled by the rioters (Utusan Melayu, 28 February I95I). The Qalam magazine singled out Dato Onn as a "lackey" in cahoots with the British with regard to the film and other issues concerning Islam. The President of UMNO was described as "mengutamakan maslahat dirinya sahaja (or concerned with his own interests and well-being)" (Qalam, Bilangan I9, February, I952).

Reflecting on the incident many years later, Tunku Abdul Rahman (Malaysia's first Prime Minister) emphasised the fact that this was the occasion of one of his open disagreements with Dato Onn (Tunku I977, I90). The Tunku then mobilised selected UMNO members and gathered signatures for a petition on behalf of Muslim men who had been arrested following the riots. The strategy worked to his advantage. On 26 August I95I, the Tunku was elected as the second President of UMNO, following the fall from favour and resignation of Dato Onn. Dubbed by Sir Henry Gurney (the British High Commissioner in Malaya) as the "hope of the Malayan peoples", the straight-talking Dato Onn bin Jaafar had received the support of the colonial authorities in advocating a slow and methodical transition towards independence. By contrast, the British were perplexed by the Tunku's political stances and manoeuvres. They viewed the 48-year-old as an elusive figure who, despite his friendly disposition and close relationship with several prominent British officials, was pressing 
for a rapid transfer of power to a Malay-led government in Malaya. To Sir Henry Gurney, the Tunku was far from being the "sort of leader who will be capable of holding UMNO together in any important controversy"; a prediction which turned out to be far from accurate.?

While the Tunku avoided stirring up Muslim feelings in such heated times, he was determined to protect the rights and interests of Malays and to garner support for his leadership and his party. He stressed repeatedly that UMNO should adopt non-violent means in campaigning for the release of convicted individuals and that UMNO members should maintain friendly relations with the British and other Europeans while avoiding the influence of ideologies that promoted violence. During his visit to Singapore in December I95I, which was hosted by the Singapore Branch of UMNO, the Tunku admonished the large audience that they should devise constructive ways to solve the social and economic problems faced by the Malay community. Rapid improvements and reform in the realm of education, according to the Tunku, were the crucial steps that had to be taken before the independence of Malaya could be formally declared. By the end of February I952, the Tunku had obtained more than 5,000 signatures on a petition against the death sentences, calling for the verdict to be reduced to imprisonment. He had played a decisive role in raising funds to aid the condemned men's dependents and was present at every court proceeding to show his overt support for those who had been convicted. ${ }^{8}$

Religious teachers and ulama (Muslim scholars) in Malaya convened country-wide meetings to discuss various means by which Islamic laws and the rights of Muslims as colonial subjects could be safeguarded. Although they unanimously agreed that the Maria Hertogh controversy had far-reaching implications for the religious life of Muslims in Southeast Asia, major splits developed within the ranks of the Muslim laity with regard to the validity of Maria Hertogh's marriage and her conversion to Islam. For example, the mufti (a Muslim scholar who interprets Islamic laws) of Johor, registered his fundamental disagreement with the fatwa $a^{9}$ issued by the mufti of Selangor that kathis who were entrusted with the registration of marriages and the arbitration of marital disputes were not authorised to perform a marriage ceremony without the prior approval of the bride's parents. This fatwa was used by the judges of the Singapore High Court to annul the marriage between Maria Hertogh and Mansoor Adabi (Nordin I990, 335-357). Several landmark conferences and seminars were organised from I95I to the end of 1953 to resolve such divergent interpretations of Islamic laws. In one of these sessions, a proposal was mooted to the effect that a Muslim political organisation was to be formed and led by those who shared the aspirations of establishing an Islamic state modelled on Pakistan. In pursuit of this long-term objective, the Persatuan Islam Sa-Malaya (the Pan-Malayan Islamic Association) 
was created in I954 which, from the I970s onwards, became commonly known as Parti Islam Se-Malaysia (PAS) (Farish 2004, I20).

If the responses of Muslims and non-Muslims in mainland Malaya were seen by the colonial government as threatening the legitimacy of their rule, developments in South Thailand and Indonesia had even more destabilising political implications. The ulama in South Thailand referred to the Hertogh case as a test by Allah and an admonition that divine laws should be preserved and not taken lightly. To them, the future course of the Muslim community in Singapore and the Federation of Malaya was highly dependent on the extent to which Muslims were willing to struggle in the defence of Islam (Melayu Raya, I8 January I95I). During his meeting with the British ambassador in Jakarta, President Sukarno referred to the Maria Hertogh case "as another serious political blunder of the West." Muslims in Indonesia, the President maintained, regarded the marriage between Maria Hertogh and Mansoor Adabi as valid. The British court's decision to nullify the marriage had brought about worldwide Muslim resentment towards Britain which would not be easy to mediate or resolve. ${ }^{\text {Io }}$

At around the same time that Sukarno made these remarks, a number of non-governmental organisations, Muslim elites and newspapers in Indonesia expressed strong and indignant views on the legal case and the riots. The Moslem Propagandist Front in Jakarta alleged that the Maria Hertogh legal controversy had brought about a widening gulf between Europe and Asia, and urged Muslims to be mindful of the urgent need to defend their religion. The Panitia Kemerdekaan Malaya (PKM, or the Committee for Malayan Independence) whose main objective was to agitate and, if necessary, to militate for the creation of an independent Malaya, called for the immediate release of Muslims who had been detained. They cited the series of arrests of Muslims in Singapore following the riots as an infringement of democratic principles and the rights of the Malays who were natives of the island. An appeal was also sent to all major Muslim organisations in India, Burma, the Philippines and Indonesia to apply pressure on the British to stop suppressing Muslims in Singapore and mainland Malaya. This stance was supported by radical youth movements which were determined to refer their grievances about Britain's suppression of nationalist movements to the United Nations (Antara, 23 December I950).

Writing in a widely distributed daily newspaper, Haji Abdul Malik Karim Amrullah (known as Hamka), a well-respected Muslim scholar and prominent member of the Muhammadiyah (one of Indonesia's largest Muslim movements), remarked that placing Maria Hertogh in a Catholic Convent was a clear sign of Western religious fanaticism. Hamka argued that, although the Muslims of Malaya had passively accepted the oppressive measures taken by the British during the Malayan Emergency, 
their will to protect their religious beliefs should not be underestimated, as shown by the riots and other forms of resistance. Hamka's argument was complemented by editorial commentaries published in Indonesia Raya - an influential newspaper which was circulated in several Indonesian provinces. The editorials severely criticised the arrests of Muslims in Singapore and advocated their immediate release (Pedoman, 20 December I950).

Several public statements were also made by a newly-established women's organisation, the Front Wanita Indonesia (the Indonesian Women's Front), which condemned the British for insulting Islam and expressed sympathy for Maria Hertogh, Mansoor Adabi and the Muslims in Singapore who were struggling for their religious rights. Representatives of the organisation urged Indonesian Muslims to give their fullest support to returning Maria Hertogh to Islam and to her husband. Other prominent Muslims in Indonesia established a provisional committee in defence of the marriage between Mansoor Adabi and Maria Hertogh. The committee authorised two renowned lawyers, Dr Datuk Djamin and D. Sujudi, to study the British court's verdict in preparation for the pursuit of a legal case. Telegrams were sent to Dato Onn reminding him of his duty to assist Mansoor Adabi in his legal appeal to the Singapore High Court. On I4 December 1950, members of the committee and other Muslim activists staged several anti-colonial protests in public places (Antara, I4 December I950).

\section{The wider Muslim world and Europe}

The Maria Hertogh legal controversy also attracted a great deal of publicity in major Muslim countries, as well as in Britain and the Netherlands, provoking strong reactions from politicians and organisations in these lands. Because Singapore was an arena where multiple Muslim and nonMuslim diasporas intersected and interacted with one another, it became a nerve centre for the transmission of news and rumours regarding the legal case (Harper I997, 26I-292; Harper 200I, I6). A small yet influential number of Indian Muslims, who were deeply involved in campaigning for the creation of Pakistan and had maintained close links with their ancestral home, kept their anti-imperialist compatriots abreast of developments regarding the battle for custody of Maria Hertogh. Arabs, who originally hailed from the Hadramaut region in Yemen and other parts of the Middle East, but were conscious of their place within a global diaspora, made effective use of familial, economic and political links in the Middle East that had been fully revived in the aftermath of the Second World War to promote the interests of the Muslim community on the island during that period (Aljunied 2007, $\mathrm{I}_{3} 3-\mathrm{I} 83$ ). 
The British were anticipating adverse statements from state authorities and Muslim organisations in Cairo following the quelling of the riots - responses that would inevitably have a rippling effect on other Muslim-majority countries. Much to their relief, the leaders of the Arab countries refrained from expressing any views on the Maria Hertogh case. ${ }^{\text {II }}$ A student association in Mecca wrote a rather inconsequential letter of protest against the British authorities' handling of the legal case and their repressive measures against Muslims. The letter was published in Malay newspapers in Singapore, and several hundred copies were reported to have been sent to the Secretary of State for the Colonies and selected religious and political leaders in Indonesia, the Middle East and South Asia.

While the British may have been pleasantly surprised by the relatively mild reactions of the Arab world to the Hertogh case, the reactions of Muslims in Pakistan were of a quite different nature, posing a threat to Singapore's security. Speaking to the news agencies in his country, the Prime of Minister of Pakistan, Liaquat Ali Khan, declared that that the marriage of the fourteen-year-old Maria Hertogh was valid from the perspective of Islam, with or without the consent of her nonMuslim parents. He was reacting to the visit to Pakistan of an Indian Muslim who wanted government officials in Karachi to protest against the draconian laws used by the British to intimidate their subjects in Singapore. ${ }^{\mathrm{I} 2}$ Liaquat's pronouncements and the Pakistani government's efforts to present the Maria Hertogh controversy in its true light, albeit with a Muslim slant, did anything but mitigate the strong reactions of the public. Motamer-e-Alem-e-Elami, a populist organisation in Pakistan, depicted British policies in Singapore as yet another example of the negative predisposition of Europeans towards Asian customs and religious beliefs. Street protests were launched in early I95I against the British handling of the legal proceedings and the arrest of Muslim leaders such as Abdul Karim Ghani, who was to have led the Singapore delegation to the World Muslim Conference in Karachi. ${ }^{\mathrm{I3}}$

The Singapore Governor initially maintained that the World Muslim Conference lacked the support of the Pakistani government, and, therefore, should not be regarded as a major threat. The event would provide an opportunity for the British Home Government to obtain the cooperation of the Pakistani authorities in clarifying the proper facts of the Maria Hertogh legal case. However, they soon realised that the conference could pose a diplomatic hazard, since Muslim leaders who were vehemently anti-European had been invited to the event. As a proactive measure, representatives from the Colonial Office were dispatched to the conference in order to provide the British government with full details on the Maria Hertogh case and the events that ensued. This would prevent inadvertent remarks from being made by Muslim 
attendees who had learned about the controversy from factions that were hostile to the British. ${ }^{\mathrm{I}}$

Indeed, the time leading up to the World Muslim Conference was a worrying period for British officials in Singapore and in Britain. From 9 to I2 February I95I, the Muslim World Conference proceeded as planned, with informal sessions held by Muslim leaders of varied nationalities and affiliations. News agencies from European and non-European countries covered the event and published day-by-day commentaries that were provided by the attendees. Even Ahmadi and Shi'ite delegates, who were regarded by the Sunni majority as heterodox, were given the opportunity to air their views on the creation of a united Muslim front. A consensus was reached at the end of the conference that the Muslim world should form a third unified coalition in the face of the dominance of the communist and capitalist blocs. Several other resolutions were passed, yet there were no references to the Maria Hertogh riots or the legal case. The Foreign Office, the Colonial Office and the Singapore authorities were relieved but puzzled by the apparently deliberate omission of the Maria Hertogh case from the conference's resolutions. The following report vividly depicts the views of the British Foreign Office:

The Conference surprisingly, avoided another controversial subject, the Bertha Hertogh case, which might have aroused the spirit of Islamic fanaticism if it had been ventilated. It has been expected that the subject would be debated, especially as one of the prospective delegates from Malaya, Karim Ghani, had appointed the girl's 'husband' as his private secretary for the Conference. The reason for the omission is not known, but the fact that Karim Ghani was unable to attend the Conference owing to his detention in Singapore following the riots of December I950, may have affected the matter. The omission of the Bertha Hertogh case is more surprising in view of the anti-Western tendencies of some of the participants of the Conference. ${ }^{15}$

One of those who attended the Muslim World Conference was a Singaporean Arab Muslim leader named Syed Ibrahim Alsagoff. When he was interviewed at the airport on his return from Pakistan, Alsagoff disclosed that, although many delegates to the conference expressed sympathy for Muslims who had been arrested and for organisations which were relentlessly agitating for justice to be upheld, they did not see the need to discuss the Maria Hertogh case in a formal setting (The Straits Times, I6 February I95I).

But the wider Muslim World was hardly as critical of the British as those in the heart of the colonial metropole. Post-war Britain was a haven for third world intellectuals and anti-colonial activists, most of whom had 
used their time in the country to champion the cause of independence, equality and fair treatment of all formerly colonised peoples and those that were still under the thumb of European rule. Muslim students living in London established a 'Bertha Hertogh Committee' to win support for the appeal in April and to agitate for an inquiry into conflicts between Islamic and secular laws. The riots in Singapore also provided politicians from the Conservative Party with a pretext to find fault with the Labour government's management of the colonies. Having won the general elections in the previous year by a narrow margin, the Labour Party was riven by political divisions, personal rivalries and a spate of resignations. The Conservatives, on the other hand, were progressively regaining public support through a re-organisation of party organs, by embracing the notion of the Welfare State, forging close ties with trade unions and promoting government-led development schemes. In the House of Commons in February I95I, opposition parties seized the opportunity to condemn the Home and Singapore governments for the breakdown in governance during the riots and the incidents that led to the death of British civilians and servicemen during the riots. A Conservative Member of Parliament, Frederick Burden, questioned the late deployment of troops to quell the riots in their early stages. Burden demanded an assurance from the Secretary of State for the Colonies that military forces would be promptly activated in the event of another major riot. Another Conservative Member of Parliament, Arthur Harvey, asked for the earliest date by which the investigation of the Commission of Enquiry would be completed. James Griffiths (Secretary of State for the Colonies) explained that the causes and factors that led to the riots had yet to be fully revealed. The government would not commit itself to Burden's proposition. In response to Harvey, Griffiths wryly noted that the "gallant Gentleman will have seen from Press reports [that] the Commission have begun their work and are taking evidence" (Hansard I95I, I276-I277).

The pride of place given to Griffiths' comments in the press deserves some further elaboration. Aside from providing updates on the progress of the Malayan Emergency, the British media seldom gave extensive coverage to incidents of violence in Malaya during the immediate post-war period. The aftermath of the Maria Hertogh riots was exceptional in the sense that it became a topic of debate for several leading newspapers in Britain (Lee 1967, 24I). ${ }^{16}$ The Daily Express and The Daily Telegraph featured the riots as a symptom of the Labour government's growing ineptness in managing racial and religious differences in the colonies. The Manchester Guardian went so far as to aver that the colonial administration in Singapore would never secure Malay support and that the post-war governments in both Britain and the colonies were rife with defects. The outbreak of riots was a "blunder" that revealed the colonial government's apparent inability to identify and address the outstanding 
socio-political grievances in the colony (The Daily Telegraph, I3 December I950; The Daily Express, I3 December I950; Manchester Guardian, I3 December 1950).

In contrast to the situation in England, the mood in the Netherlands was triumphal, tinged with a degree of prudence on the part of the authorities there. The Dutch monarch, Queen Juliana, who was actively promoting the welfare of children in developing countries, expressed her interest in knowing the true facts of the Maria Hertogh controversy. Concurrently, a strict warning was issued by the government to all Dutch newspapers to avoid sensationalism and misreporting of the riots and the legal case. Dozens of Christian organisations and parties were also advised to practise moderation in cheering for the Hertoghs on their arrival at Schiphol airport on I3 December I950. Though the Dutch authorities were unsuccessful in preventing the cheers of large crowds at the airport, pre-emptive measures prevailed on other occasions. At Bergen-op-Zoom, where the Hertoghs lived, no extensive celebrations were observed. Newspapers in the country covered the story in great detail, yet none highlighted the political and religious aspects rooted within the legal case except to say, as the British ambassador observed, "that the riots were significant of the present tension between the East and the West. Comment in the responsible newspapers were on the lines that unhealthy interest was being shown in this little girl and that the sooner the whole story was forgotten the better it would be for all concerned. In short... the Government has not done badly, though for some reason or other something seems to have gone wrong at Schiphol itself." ${ }^{17}$

On 27 March 195I, the Breda Court in the Netherlands declared that Maria Hertogh was a Dutch citizen and, therefore, under Article 86 of the Dutch Civil Code, she was to be considered as a child and her marriage was invalid. Neither Maria Hertogh nor Mansoor Adabi were present or represented during the proceedings. Following a request from the Dutch Public Prosecutor, who was acting on instructions given by Baron van Ittersum at the Ministry of Foreign Affairs, the case was adjourned in view of the appeal, which had yet to be heard at the High Court in Singapore. Dozens of Roman Catholic organisations in the Netherlands demonstrated in protest of the adjournment of the court proceedings. The Dutch High Court was issued with warnings to categorically invalidate Maria Hertogh's marriage to Mansoor Adabi. Failing that, Catholic support for the government would be called into question. In view of such fervent political debate, the term of office of Jacob van der Gaag (the Acting Consul-General of the Netherlands in Singapore) was extended until the end of the appeal, as he was deemed to be acceptable to the Catholics in the Netherlands. The Breda Court resumed its proceedings on 8 May i951. A week later, the marriage between Maria Hertogh and Mansoor Adabi was annulled..$^{18}$ 
Such determined attempts to repatriate Maria Hertogh through legal and other means did not reflect the overall views of Dutch society. In fact, several Dutch personalities had gone to the extent of advocating Maria Hertogh's return to the fold of her foster mother. Three Dutch-Muslim organisations, namely, the Association of Islamic Students, the Moslem Mission in Holland and the Islam Union, made a public declaration that Maria Hertogh's repatriation to Malaya would remedy the distrust that had developed among Muslim leaders towards the Netherlands. Several other newspapers in the Netherlands reported on the difficulties encountered by the girl. Nurtured and cared for by Che Aminah from an early age, Maria Hertogh was only fluent in the Malay language and was accustomed to Malay dietary habits, beliefs, and lifestyle. This may have contributed to her recalcitrance in the face of the European lifestyle of her natural parents and siblings. ${ }^{19}$

\section{British strategies}

Thus far, I have discussed the wide array of responses by both regional and global communities during the aftermath of the Maria Hertogh riots. While these developments may appear exceptional when observed in isolation, they are not atypical. Popular criticism and dissent against European management of mass violence in the colonies were characteristic of the years following the Second World War. The African historian Frederick Cooper has correctly observed that colonial regimes in the I950s were perceived worldwide as relics of the old order, especially in their recourse to the use of brute force and naked violence to obviate resistance. They (the colonialists) "were moving targets for criticism, for they sought to reposition themselves in a progress-oriented world" (Cooper 2005, 37).

It was the recognition of the fact that the riots had turned into a diplomatic and political morass that prompted the British to respond in a sophisticated way so as to recover their public image and political legitimacy. A careful reading of a wide selection of colonial documents written during this period suggests the coming together of several decisive measures. The first was to capitalise on the global information order that flowed throughout the post-war British Empire, Europe and the newly independent nations. Support for native collaborators and elites in Muslim countries and the Netherlands was harnessed to restrain the outraged populace in these places. In mainland Malaya, the British encouraged Muslim elites from various states and organisations to publish their appeals for Muslims to remain calm and express the hope that nonviolence and the ideology of peace would be upheld by all parties. At the same time, close lines of communication were maintained with selected 
politicians in the Netherlands by way of reminding them that press sensationalism surrounding the Maria Hertogh case would lead to disastrous consequences in Singapore. Meanwhile, the British Foreign Office in London instructed British ambassadors to major Muslim countries, who were stationed in cities such as Jakarta, Karachi, Cairo, Baghdad, Tehran, Jeddah, Damascus and Amman to provide updates on any disturbances caused by the Maria Hertogh case and to provide detailed reports of any attempts to exacerbate Muslim hostility towards Britain. Since the international context had a strong bearing on the course of events in Singapore, it was of paramount importance that potential threats in these countries were detected as early as possible. Crucial information was sent to London and relayed to Singapore almost immediately. ${ }^{20}$

In the realm of espionage, the British obtained intelligence regarding subversive elements within UMNO, the Peninsular Malay Union and other Malay organisations, which promoted independence by radical means in the wake of the Maria Hertogh riots. These developments were suspected of having a close influence on Muslim military and police officers in Singapore, who had maintained strong networks with political activists in the Malayan Federation. The British also kept abreast of a revival and upsurge of interest in the ideology of Pan-Islamism, which was enmeshed with the ideals of nationalism. Muslim students who returned from their studies and sojourns in Cairo and Mecca were active in spreading anti-British and Pan-Islamic ideas in Malaya. Although numerically insignificant, such people were deemed to be potential threats to security in Singapore. The British intelligence services also monitored numerous visits by Inamullah Khan (President of the Pakistani Youth Movement), which were hosted by prominent Muslims in Singapore. While there were no signs that these visits had provoked anti-colonialist attitudes, the British did not discount the possibility that speeches made by such personalities could spark sentiments which "may be latent and could easily be touched off, as was shown in the Hertogh case". ${ }^{2 \mathrm{I}}$ Politicians and radical ulama who converged in Singapore and Malaya en route to Mecca during the pilgrimage season, were kept under close surveillance to ensure that any negative influences on the part of these personalities could be swiftly dealt with. Nevertheless, no untoward incidents related to the Maria Hertogh case were reported towards the end of $19533^{22}$

Propaganda and a public show of respect for Muslims and Islam constituted the second key component of British attempts to smooth over the legitimation crises they faced in the aftermath of the Maria Hertogh riots. Officials in the colonies where Muslims were in the majority were instructed to combat the propaganda of 'extremists' by giving widespread publicity to the verdicts passed by the Singapore High Court. They were required to emphasise, among other things, that the Maria Hertogh case was legal rather than discretionary, and that all judgments were decided 
based on the provisions of law. ${ }^{23}$ Much press publicity was concurrently given to speeches made by high-ranking British officials based in Singapore in an effort to repair the damaged ties with influential Muslim leaders in Southeast Asia. In an inaugural address at the Southeast Asia Muslim Missionary Conference, which was held in Singapore on 24 and 25 December I950, Malcolm MacDonald, the United Kingdom Commissioner General for Southeast Asia, commended the conveners for taking the lead in strengthening the religious commitment of Muslims in Southeast Asia in the midst of an unending battle against secular ideologies which promoted violence. He enjoined the representatives from different territories to establish a close working relationship so as to bring about a climate of religious freedom and mutual tolerance (The Singapore Free Press, $26^{\text {th }}$ December, 1950; The Straits Times, $20^{\text {th }}$ December, 1950$)$.

During a tea party held in the following month in the presence of representatives of different religious faiths in Singapore and Malaya, the Singapore Governor, Sir Franklin Gimson, spoke about the impartiality and independence of British courts. He stressed that maintaining law and order was crucial in a multi-religious and multi-racial setting such as Singapore, and appealed for members of all religions to work hand in hand with the government to prevent disorder and chaos. "Muslim subjects of the King", according to the Governor, "have always held a high place in His Majesty's regard and have always been considered as among his most loyal supporters. The Muslim community in Singapore has, therefore, a high reputation to maintain and I hope that they will do nothing to besmirch this reputation and so to bring themselves and their religion into disrepute" (The Straits Times, I3 ${ }^{\text {th }}$ January, I95I). It is worth noting here that Gimson's discourse on governmental non-interference in judicial processes in Singapore was far from truthful. The Governor had taken the proactive move to conduct secret negotiations with the aim of inducing Mansoor Adabi to dissolve his marriage with Maria Hertogh in accordance with the laws of Islam. Several well-respected Muslims in the colony supported the plan, but all in vain. Mansoor Adabi was unshakable in his determination to pursue his appeal to the Singapore High Court, although this appeal was eventually dismissed.

The widespread press coverage given to the findings of the Commission of Enquiry was another major step taken by the British to identify the manifold factors that led to the outbreak of the riots and to impress critics, opposition parties and anti-colonial activists in Malaya and England that improvements would be made in the management of the colony. Michael Keith has pointed out that Commissions of Enquiry "exist in a political environment and are implicated in a political strategy from the moment at which they are appointed and their personnel selected to the moment in which they report, right on the manner in which they are remembered" (Keith, I993, 74). This held true in the case of the 
Commission of Enquiry on the Maria Hertogh riots established on January I95I whose conclusions were, in many respects, designed to protect the integrity and legitimacy of the high command of the colonial administration. As the most prominent figure in the colony, the Singapore Governor was not placed under oath because of the British legal concept of sovereign immunity. This in itself was sufficient to absolve a prominent civilian official of any blame for the riots.

The Commission of Enquiry interviewed a total of 136 police officers, government servants, Muslim elites and members of the public as part of its fact-finding efforts. Investigative tours were conducted in the areas where the riots had taken place, and several films of riot incidents and an anti-riot drill were also reviewed. On 7 August 195I, the Report of the Commission of Enquiry, popularly known as the 'Leach Report', was published and it featured in every major newspaper in Singapore, Malaya and England. Having been modified in accordance with the politics and anxieties of the time, it is unsurprising that the Leach Report failed to provide a balanced or definitive account of the causes and events that led to the outbreak of the Maria Hertogh riots. The central purpose of the Leach Report, Mary Kilcline Cody suggests, "seems more didactic than investigatory and it may be seen as a lesson for colonial governments rather than an attempt to establish the causes of the riots" (Cody 200I, I03-I04). Going beyond this, I would argue that the Commission of Enquiry had failed to pose a basic and crucial question: Why did the riots occur in some localities, yet not in others? Due to this oversight, the Leach Report made no reference to the socio-economic marginalisation, deprivation, alienation and grievances of Malays and other communities, which could well have explained the mass participation and rapid spread of the riots in the villages, ghettos and other suburban parts of Singapore. The British only became aware of the correlation between mass violence and the socio-economic marginalisation of the local community during a Governors' Conference held a year after the publication of the Leach Report, when issues pertaining to Muslims in Singapore were deliberated at length. ${ }^{24}$

Although superficial and contested, the Leach Report had considerable influence on public understanding of the riots and worked to the benefit of the colonial government. The report attributed the outbreak of the riots to a few key factors. Foremost among these was the intense feelings which developed within the Muslim community in Singapore, arising from the verdict regarding the custody of Maria Hertogh. Another aggravating factor was Maria Hertogh's stay at a Roman Catholic Convent, which heightened suspicions that there had been prior plans to forcibly convert the girl to Christianity. The third cause was the publicity given by the press to the legal case and Maria Hertogh's life at the convent. Muslim hatred of Europeans and Eurasians in the colony 
was further intensified by public statements and speeches made by the "Nadra Action Committee", whose chief members were Karim Ghani, Dr Burhanuddin, Mohammed Taha bin Kalu, Syed Ali Al-Attas, Darus Shariff and Mohammed Mustaza. Much of the document was devoted to providing intimate details on the role of the police force in the riots, with little coverage of the civilian government's mishandling of the legal controversy. The report ascribed the riots to the failure of the Malay police in particular and to the police force as a whole for having failed to anticipate the possibility of an outbreak of mass violence and to employ necessary force at an early stage. This revealed the vulnerability of the security agencies to riots, resulting in the spread of mass violence from the area just outside the Supreme Court to other parts of the city. The Report recommended comprehensive reforms to remedy the problems of weak leadership, corruption, poor discipline, disorganisation and low morale within the police force. ${ }^{25}$

Above all, the British adopted a policy of appeasement and concession in order to redress both Muslim and non-Muslim grievances. The British authorities made full payment on all claims submitted by the Dutch Consulate to the tribunal in charge of compensating various parties who had suffered from the loss of kin and property during the riots. The tribunal reported that, although the application in respect to the damages incurred by the Dutch Consulate was not supported by sufficient evidence, "in this case, diplomatic courtesy would apply [italics mine]." ${ }^{26}$ All applications for compensation from civilians belonging to the European and Eurasian communities were approved and widows of uniformed servicemen were endowed with pension and monetary awards ranging from $\$ 10,000$ to $\$ 20,000$. Although the tribunal denied monetary compensation to Muslims in Singapore, they gained in other ways.

For many months following the riots, Muslims in Singapore and Malaya petitioned for the pardon of Thamby bin Osman, Habee Kassim bin S.A. Kader, Thamby bin Sidek and Dawood bin Mohammed, who had all been sentenced to death for the murder of a British serviceman named John W. Davies. They were elated when, on 22 July I952, the newly-installed Singapore Governor, John F. Nicoll, commuted the sentences of the four men. Instead of being executed, they would serve terms of life imprisonment, and would be eligible for early release for good conduct. The Utusan Melayu and Majlis editorials registered their appreciation of Nicoll's gesture of clemency and commended the Governor's move as "wise" (Utusan Melayu, $24^{\text {th }}$ July, I952). The British went on to acquiesce in the religious demands of Muslims and paid tribute to the contribution of the minority community in the development of Singapore and Malaya. The Municipal Commission assented to various requests by Muslim civil servants to be exempted from performing 
tasks that were contrary to their religious beliefs. Such a shift in policy stemmed from the demands of a nurse who applied for an exemption from family planning campaigns. The nurse argued that the campaigns were contrary to her religious beliefs (The Straits Times, 2I $\mathrm{I}^{\text {st }}$ July, I95I). The quasi-governmental Muslim Advisory Board was expanded through the incorporation of three prominent personalities: Mahmood bin Abdul Wahab (a former Police Inspector), Syed Abdullah bin Yahya (the President of the Singapore Arab Union) and Haji Jubir Haji Amin (a committee member of Jamiyah). The lifting of restrictions on the annual celebrations of the Maulidul Rasul (Prophet Muhammad's Birthday) in Singapore and Malaya (despite the ongoing Malayan Emergency) further encouraged positive feelings towards the colonial regime among Muslims (Government Gazette, No. 66, Vol. VI, May I95I; Utusan Melayu, I2 ${ }^{\text {th }}$ December, I95I).

\section{Conclusion}

Viewed in terms of the number of casualties and the extent of the damage to property, the Maria Hertogh riots seemed to be less serious than major disturbances in other British territories in the post-war era. For example, in Bengal in November 1947, more than 200 died during what has been described as one of the bloodiest incidents of communal rioting between Muslims and Hindus in India (Batabyal $2005,272)$. The same degree of bloodshed took place in other colonies, such as Aden (in 1947), the Gold Coast (in I948) and Nigeria (in I949). Yet the significance of the mass violence that broke out in Singapore in December 1950 was to be found not so much in the lives it claimed than in the wide-ranging responses by the regional and global communities, as well as the structural vulnerabilities of the colonial system which had been laid bare. Reminiscing about his time as Deputy Under-Secretary of State for the Colonies, Charles Jeffries noted that the Maria Hertogh riots were particularly significant, as they had exposed the weaknesses of British policies in the post-war period. The two days of violence severely stained the island's reputation as one of the empire's most secure and strategic points (Jeffries I952, 203). ${ }^{27}$

With these observations in mind, this essay has sought to move beyond the uncovering of the contributing factors of the riots and the means by which they were suppressed to explore the lesser-known terrain of the reactions of regional and global actors, regardless of the various strategies which this particular colonial regime employed in the riots' aftermath. By viewing a case of collective violence through the lenses of 'outside in', 'bundles of relationships' and 'complex web', while framing the event against the backdrop of a global climate of decolonisation, we 
can see that resistance to the colonial administration remained intense following the quelling of mass violence and was manifested in various forms in Southeast Asia, across the wider Muslim World, and even as far away as Britain and the Netherlands.

Nonetheless, it was the recognition of the need to reform, adapt and react swiftly to the crisis through a combination of strategies that enabled the British to deal effectively with the changing conditions on the ground in the aftermath of the Maria Hertogh riots. The colonial government was able to anticipate and cope with such threats by tapping into the global information order. Through a policy of appeasement and concession, the British government quickly regained the trust of its subjects and diplomatic partners. Propaganda and a public show of respect for Muslims became effective tools in averting resistance in the aftermath of the riots. Underlying these strategies were the crucial roles played by selected officials and politicians in London and the outlying colonies and the support of various local organisations and personalities, who aided in the process of recovery and conciliation. Indeed, due partly to the variety of measures undertaken by the colonised and the colonisers, Singapore remained free from major outbreaks of violence perpetrated by Muslims and related threats emanating from overseas for more than four years after December 1950. The next serious riot (which has yet to be interpreted beyond its local context) occurred on I3 May I954, when Chinese students took to the streets to protest the National Service Ordinance. The rioters were effectively crushed by scores of policemen, who were criticised for their indiscriminate employment of "excessive force" (Yeo I973, I9I-I92).

In conclusion, this chapter has provided a new frame of reference with which riots and mass violence in colonial settings can be better understood. This is accomplished through establishing connections between local, regional and global developments and demonstrating that the effects and responses to riots in the colonies were, in some instances, farreaching and more serious than when viewed merely within their local confines. Seen from this vantage point, it becomes clear that colonial regimes implemented multi-faceted strategies and policies to regain the initiative when challenged. The sense of the past that emerges from this method of analyzing riots is thus one that is more analytical, if not more comprehensive: a history that brings together the roles of the colonised, the coloniser and even those who existed beyond the imperial system into a single framework of analysis. That said, there is much to be done in the effort to rethink and reconceptualise the study of riots in colonial Southeast Asia. The first step towards this is the development of a sense of openness among Southeast Asian historians to consider donning new scholarly lenses by incorporating the concepts, approaches, and methods devised by scholars outside their fields of expertise. Only then can new 
and refreshing pathways in the historiography of violence in Singapore and the region be opened up for comparison with case studies from other parts of the world.

\section{Notes}

I Recent studies that lend credence to this assertion are (Davidson 2008; Purdey 2006; Sidel 2006).

2 'Statement by George G. Thomson, Public Relations Secretary (Singapore), 22 February I951', CO 953/I0/I.

3 'Minutes of the 2oth Meeting, held in the Colonial Secretary Office, Singapore, on Friday, 29 December 1950', CO 537/6579 and 'Federation of Malaya - Political Report No. I for January I95I', CO 537/734I.

4 'Political Summary - I December I950 to 3I January I95I Part III - Colonial Territories - Singapore', CO 537/7346.

5 'Federation of Malaya - Political Report No. I for January I95I', CO 537/734I and 'Extract from PMR 2/1951', CO 537/7302.

6 'Singapore Political Report for January I952', CO 1022/206.

7 'Sir Henry Gurney to John D. Higham, 29 August 1951', CO 537/7297. Dato Onn was also described by the Secretary of State for the Colonies as the 'the ablest and the most influential Malay leader.' See 'MAL.C. (5I), 26 July I95I, PREM 8/1406.

8 'Malaya - Monthly Political Intelligence Report - I5 March-I5 April I952', CO 537/7343.

9 An Arabic word for 'legal judgment' or an explanation given by a Muslim scholar on matters pertaining to the understanding and practice of Islam.

IO 'Franklin Gimson to Foreign Office, 25 February I95I', CO 537/7302.

II 'From Cairo to Foreign Office, 8 January I95I', FO 37I/93II4.

I2 'Commonwealth Relations Office to U.K. High Commissioner in Pakistan, I February I95I', CO537/7302.

I3 'United Kingdom High Commissioner in Pakistan to Singapore, 23 January I95I', CO $537 / 7302$.

I4 'Malcolm MacDonald to High United Kingdom High Commissioner in Pakistan, 23 January I95I', CO537/7302 and 'Malcolm MacDonald to Foreign Office, 24 January I95', CO 537/7302.

I5 'Recent Pan-Islamic Movements', FO 37I/91250. See also, 'U.K. High Commissioner in Pakistan to Malcolm Macdonald, I4 February I95I', CO537/7302.

I6 'Monthly Political Intelligence Reports: Federation of Malaya: January-February, I95I', $\mathrm{CO} 537 / 7343$.

I7 'Philip Nichols to J.D. Murray, I9 December I950', FO 37I/84677.

I8 'Transmittal of General Conditions Report on the Singapore, Kuala Lumpur and Penang Consular Districts for April I95I', RG 59, 746F.00/5-I95I, NACPM and 'Verdict of the Breda Court, I5 May I95I', Mansoor Adabi Papers.

I9 'Transmitting General Conditions Report for the Singapore, Kuala Lumpur and Penang consular districts for the period February I-I5, I95I', RG 59, 746F.00/2-285I, NACPM.

20 'Singapore to U.K. High Commissioner in Karachi, I $8^{\text {th }}$ January I951', CO 537/7302.

2I 'Review of Factors Liable to Affect Internal Security, Singapore, as on I ${ }^{\text {st }}$ October, I953', CO $1022 / 248$.

22 'Review of Factors Liable to Affect Internal Security, Singapore, as on I ${ }^{\text {st }}$ October, I953', CO $1022 / 248$.

23 'D. MacFarlane (Foreign Office) to S.H. Evans (Colonial Office), 3I ${ }^{\text {st }}$ December, I95I', FO 371/93II7. 
24 'Extract of Minutes of Malaya/Borneo Governors' Conference, I5 January 1952', CO 1022/429.

25 'Riots: Singapore; Report of Commission of Enquiry: Leach Report (I95I)', CO 537/7248.

26 'Report of the Proceedings of the Riots Claims Tribunal, I9 ${ }^{\text {th }}$ June, I95I', CO 953/10/2.

27 Singapore was regarded as a base for sustaining an 'empire of points' in the post-war period. For a detailed discussion of the notion of the 'empire of points', see: (Hack 200I, 300). 


\title{
10 The British Military Withdrawal from Singapore and the Anatomy of a Catalyst
}

\author{
Loh Kah Seng
}

\begin{abstract}
"It was not even a sell-out: it was a handout, with virtually nothing demanded or even bargained for in return", an angry Arthur de la Mare, the former British High Commissioner in Singapore, wrote to the Secretary of State for Foreign and Commonwealth Affairs in November I97I. De la Mare was reflecting on the handover of the British military bases to the Singapore's People's Action Party (PAP) government between I968 and the end of December, when the remaining British forces would

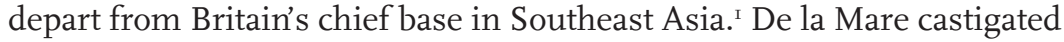
his colleagues for conceding the bases to Singapore without retaining a say in their deployment for economic purposes. With more than a tinge of regret, he lamented, "Had we so wished we had the opportunity not only to retain all that we needed but also to transform Singapore from a doubtful military bastion (it was never a very good one) into the forward base of British business and commerce in East Asia". ${ }^{2}$ It was a scathing comment on the end of Singapore's role in the British Empire.
\end{abstract}

\section{Between crisis and catalyst}

Yet, De la Mare's remarks also reveal much about Singapore's emerging new place in world history as a development-driven, industrial state at the end of the ig6os. They lend support to a new approach that extends beyond the imperial and national history frameworks within which narratives of the British withdrawal have usually been located. Imperial historians such as John Darwin, looking through a Britain lens, typically focus on its struggles to maintain a world presence in the I96os and the convoluted process by which this 'East of Suez' policy was finally abandoned (Darwin I988, I99I). When the call to pull out was finally made in January I968, some historians have attributed it to the force of economics, particularly the sterling crises of 1966-67 and the devaluation of the pound in November I967 (Darby 1973; Butler 2002; Hyam 2006). Other historians have pointed rather to the political actors: specifically, the cabinet reshuffle that undermined the old guard which had supported the 'East of Suez policy (Darwin I988; Pickering I998). 
In this literature, Singapore appears, if at all, as a passive, hapless appendage. By contrast, nationalist historians take a Singapore vantagepoint and view the run-down as one of a number of key events which enabled the making of a 'nation'. Like their imperial counterparts, they also frame the withdrawal as a crisis, but as Singapore's crisis; this is encapsulated in the numerical terms in which the pull-out is usually framed: the economic importance of the bases, the number of workers affected and the blow to gross domestic product. C.M. Turnbull's standard history text adopts the view that the pull-out momentarily 'clouded' the nation's prospects for survival and turned out to be a blessing in disguise (Turnbull I989, 293-4). A more recent book maintains that the run-down "galvanised the fighting spirit of Singapore leaders, who went on to rally their people all the more" (Lee 2008, 265). Given the purported severity of the withdrawal in nationalist history, its actual impact on Singapore was so strikingly minimal that it ran the risk of becoming a non-event.

The withdrawal, which involved much British and Singapore negotiation and collaboration, sits clearly at the nexus between the imperial and national histories. De la Mare's complaint provides a glimpse into how freshly sovereign Singapore not only survived the crisis, but transformed it into a platform for a massive industrialisation programme based on foreign capital investment. The pull-out is an excellent case study on the linkages between imperial, national and local histories. Some scholars have located Britain's decision to withdraw at the intersection between metropolitan politics and geopolitical developments in Southeast Asia (Hack 200Ia; Hyam 2006). This paper follows a similar approach by examining the dynamics of Anglo-Singaporean collaboration for the mechanics of the pull-out, and adds a new one: social history. By using both official records and oral history interviews, this paper examines how a transnational event started by Britain's power-brokers became a path-breaking catalyst for development thousands of kilometres away in a micro-state, with significant consequences for the life and work of its people.

The key to Singapore's active connection to the imperial history of the British withdrawal lies less in political than in social and development history. The late colonial regime of post-war Singapore had launched a long process of transforming the island into what James Scott terms a "high modernist" state, geared towards development and governed rationally on scientific principles (Scott I998). By the time the accelerated timetable for the pull-out was announced, Singapore was well on its way to becoming such a society; in housing in particular, the relocation of semi-autonomous informal dwellers to public housing was already effectively integrating them into the formal structures of the state (Loh 2009a, 2009 b). The British run-down facilitated this long-term process in several ways: in the handover and economic conversion of the bases, the 
growth of the industrial economy, retraining of redundant base workers, a massive expansion of technical and vocational education, and instilling social discipline in labour. While the official terms describing the event, namely, 'withdrawal', 'pull-out' and 'run-down', implied a contraction, it really prompted the opposite: development, conversion and mobilisation.

In this crucial sense, the British withdrawal was less a crisis - for either Britain or Singapore - than a catalyst, and it underscores the theme of change and transformation so central to the making of modern Singapore. The frame of crisis entails that, once it is resolved, history comes logically to an 'end', and this under-emphasises the terms of historical inquiry. The frame of catalyst, however, reveals not only the mechanics of crisis resolution, but also extends the enquiry forward in time. Although most of the concerns about the pull-out did not materialise, the withdrawal was nevertheless certainly not a non-event in history, rather it provided the impetus for magnifying and accelerating policies of change that had been initiated earlier. This approach can also be seen in Khairudin Aljunied's recent thought-provoking study of the I950 Maria Hertogh riots. By bypassing the usual subject of the causes of the riots and exploring instead their 'aftermath', the historian can link up the imperial, regional, national, and local levels of history, thus providing greater insight into an event (Aljunied 2009b, I30).

\section{Decolonisation and development: the bribe and the sweetener}

When British Prime Minister Harold Wilson announced the accelerated timetable for Britain's pull-out from east of Suez in January I968, it meant that British forces would vacate the island completely by March 1971. This was a considerably shorter schedule compared to that of the I967 British Defence White Paper, where half the forces in Southeast Asia would pull out by I970/7I and the remainder in the mid-I970s. In Singapore, the 56 British military sites occupied a tenth of the total land area and contributed a fifth of gross domestic product. One-sixth of the island's labour force depended on the bases for work, either directly for the 4,450 enlisted and 23,000 civilian Singaporeans, or indirectly, including numerous service workers such as barbers, bus and taxi drivers, shopkeepers, and some 8,000 female domestic workers (or amahs) (Singapore Parliamentary Debates, henceforth SPD, 7 September 1967, I73-4). The run-down would also place a heavy economic burden on Singapore, which would need to build up its own defence and compensate for the loss of local spending by the British services. Singapore also faced a larger perennial challenge since the end of World War Two to industrialise and provide work for the growing numbers of young job-seekers and the unemployed (Ministry of Labour I977a). Speaking to Parliament when the accelerated withdrawal timeline 
was publicised, Minister for Finance Goh Keng Swee warned that about half of the labour force employed at the bases would be retrenched between I967 and the actual run-down in December I971 (SPD, 3 December I968, $38,59)$.

These were the 'facts' of a national crisis that never came to pass. The question of defence was resolved through the creation of a citizen army and Singapore's participation in the Five Power Defence Arrangement, which was signed in I97I (Chin I983). The economic impact was on the whole offset by the government's counter-recessionary development plans, which facilitated the expansion of manufacturing, trade, transport, banking and finance, and tourism (Yeo I970; Hon I973). The departing British themselves contributed significantly to this growth by handing over the military bases to Singapore for defence and development, towards which they also provided a sum of $£ 50$ million as Special Aid over five years to help the island manage the crisis. Singapore's unemployment rate tumbled from $8.1 \%$ in 1967 to $4.5 \%$ in I973, while the economy experienced robust double-digit growth rates in this period.

Central to Singapore's ability not only to avoid the predicted calamity but also to transform itself into a model of growth was the close collaboration between the British and PAP governments. While part of this relationship had always been visible in formal politics and diplomacy, much of it was less immediately obvious, but nonetheless just as crucial (in the form of development projects). Since the end of war, these had been integral to British decolonisation in Singapore and were indeed so in wider imperial practice; from the mid-I950s onwards, an important mission of the British Colonial Office was to ensure the orderly process of decolonisation by providing economic aid to the colonies through the Commonwealth (Boyce I999, I79-83). This "renewed sense of imperial purpose" led Britain to spend $£ 344$ million between I946-70 in an attempt to establish a "partnership" with its colonies throughout the world (Stockwell 2008, 274). In post-war Singapore and Malaya, the British sought to safeguard their economic and strategic interests in the region by restructuring local societies and economies in their own image (Tarling I993). Decolonisation, then, did not simply mean grooming local politicians who appreciated British interests or suppressing 'communists', but also engineering a viable economy and a citizenry instilled with the requisite social discipline.

This collaborative relationship became clear when the PAP came to power in I959 and Singapore became a self-governing state. Despite some initial anti-colonial gestures, the new government quickly put into practice level-headed programmes of development, integration and mobilisation. The continued presence of the British military bases was accepted, even welcomed. At Singapore's independence in I965, the 
left-wing Barisan Sosialis, the main opposition party, demanded the immediate removal of the bases, arguing that they not only encroached on Singapore's sovereignty but were launching pads for Anglo-American aggression in the region (Plebeian Express 29 September 1965, 2). The government pointed to the bases' contribution to the city-state's defence and economy. In December, the Minister of State for Defence Wee Toon Boon referred to the continued presence of the British naval base at Trincomalee in Ceylon for nine more years after the island was granted independence in I948 (SPD I7 December I965, 309).

The key local players in this Anglo-Singaporean collaboration were Prime Minister Lee Kuan Yew, his deputy Goh Keng Swee and a supporting cast of senior civil servants. Much has been written, including by Lee himself, about his rush to London following the announcement of the accelerated withdrawal and his success in obtaining an extension of the final run-down from March to December 197I (Lee 2000). But the roles played by the Singapore leaders went deeper. From the start, Lee and Goh had different responses to the accelerated pull-out. On reading an advance text of the withdrawal schedule in January I968, "Mr Lee appeared stunned and took some time to adjust himself", while "Dr Goh Keng Swee read the letter without any emotion and did not seem surprised by it". ${ }^{3}$ A later British document exaggerated the reactions of Lee and Goh as, respectively: "If you have to go, at least do not scuttle off and thereby rock the boat" and "If you have to go, go quickly because we want the real estate". 4

Despite these initial reactions and some disagreements over the details of the development plans, Lee and Goh both agreed on the significance of the pull-out and the substance of Singapore's response. Lee was less worried about the actual economic effects than the psychological impact: the "crisis of confidence... with repercussions on investment and the expansion of jobs". "This was something which we saw as a contingency which must occur", Lee said in an interview in January I968, "[I]'s a question of timing". ${ }^{6}$ The accelerated run-down would, in his view, deprive Singapore of the requisite 'breathing space' needed to build up its defence and industry.7 Goh shared Lee's concern about confidence, while his real worry, like Lee's, was about security. Pondering the possibility of the run-down in early I966, he even wondered if "the resulting slump might be no sad thing if it would bring down costs in Singapore". ${ }^{8}$ What the PAP leadership did in response to the accelerated timeline was not simply to address the economic effects, but to maintain investor confidence in Singapore.

Britain, the perpetuator of the 'crisis', was willing to help Singapore do this. In appraising the purpose of the Special Aid later, British High Commissioner de la Mare bluntly stated in January I970 that "the $£ 50$ million 
was a bribe to keep the Singaporeans sweet" and achieve the three main aims of the British pull-out:

a to ensure the orderly withdrawal of British forces in accordance with our plans

$\mathrm{b}$ in the interests of political stability in the area to ensure the prospect of a viable economy in Singapore and to avoid endangering the economy of Malaysia, and

c to safeguard our own trading and investment interests. ${ }^{9}$

The British accordingly took a "general and flexible approach" to the transfer of the bases. ${ }^{\circ}{ }^{\circ}$ As early as November I967, the British Ministry of Defence had accepted that "if it [the transfer of British lands] should come to a local argument, we have virtually no bargaining position at all". ${ }^{\text {II }}$ Half a year later, when a Singapore delegation visited London to negotiate the terms of the Special Aid, the discussion focused on using the aid for development in the public and private sectors (particularly manufacturing and tourism), and ensuring that the approval of projects, disbursement of funds and repayment of loans would be simplified. ${ }^{\mathrm{I2}}$ There were no serious disagreements over policy. As J.Y.M. Pillay, Permanent-Secretary at the Ministry of Finance, who took part in the aid talks, stated in December I967, Singapore had to "take organisational measures to put this aid to effective use". ${ }^{\text {I3 }} \mathrm{He}$ felt that the amount of aid was "not ungenerous". ${ }^{4}$

Another example of Anglo-Singaporean collaboration can be seen in the 'Malta precedent', which highlights Singapore's location in a wider Commonwealth history in the late I960s. After visiting Malta in I967, which had experienced a similar run-down, Lee Kuan Yew was extremely critical of its alleged "aid dependency" mentality, particularly of Maltese dock workers playing water polo in the naval dockyard (Lee 2000, 70-I). Like Singapore, Malta obtained its independence from Britain in I964, but allowed the British to retain their military facilities on the island until I979. Malta was also economically dependent on the British, with I3\% of its gainfully employed population working in the bases (Craig I99I). In fact, the Singapore government learned positive lessons from the Malta experience. In their exploratory negotiations with the British on the terms of the Special Aid in October I967, the Singapore side repeatedly referred to the Malta precedents, e.g. transferring all British assets to the Singapore government without charge. ${ }^{15}$ The provision of a three-month long retraining programme for retrenched base workers, discussed below, was also a Malta precedent. ${ }^{16}$ So little of this has been acknowledged in public history, because Lee had not desired the Special Aid programme to be given undue coverage in Singapore, for fear that the people would "get into a Malta frame of mind". ${ }^{17}$ The way the 'Malta precedent' has been discursively rendered in Singapore history is testament to the 
high modernist social engineering which occurred during and after the British withdrawal, as determined by the PAP government and particularly by Lee himself.

\section{'No haphazard takeover': conversion, redundancy and retraining}

One strand of the accelerated withdrawal from Singapore led to another. The pursuit of economic development was to some extent mandated by the anticipated effects of the British withdrawal. In I968, the PAP government quickly committed \$ I50 million to a counter-recessionary plan and, over the period of the pull-out, a total of over \$ I billion. Public works and construction were key planks in this programme, to which an additional $\$ 400$ million was allocated to the I968 budget to offset the deflationary effects of the run-down. The authorities also relaxed plot ratios in the Central Area and provided financial incentives, such as reduced property taxes, for private developers to increase the speed of construction of commercial buildings, offices and hotels, and other urban renewal projects (Singapore I975). Not all the development efforts were, however, reactive: major construction projects originally planned for the late I970s, such as road, drainage and sewerage development, land reclamation, public housing, and urban renewal, were also brought forward to absorb redundant labour (Tan I972). De la Mare found Singapore's initial anxieties over the pull-out to be remarkably 'short-lived', quickly replaced by an acute economic sense. ${ }^{18}$ Other British officials concurred in I970 that "[a]lthough our declared aim was to mitigate the economic consequences of our withdrawal, in the event Singapore has adjusted to this more rapidly than we anticipated". ${ }^{\text {I9 }}$

The Singapore government also established the Bases Economic Conversion Department (BECD). Under the direct purview of the prime minister, the department attempted to rigorously deal with the multi-faceted legal, economic and technical issues related to the withdrawal through a single public body. Its leadership, which was inter-ministerial, comprised Hon Sui Sen, the Department's Commissioner and Chairman of the Economic Development Board (EDB). Hon's deputies were K.R. Chandra, the Permanent Secretary of Law, in charge of issues of transfer, conversion and land use, and J.Y.M. Pillay, his counterpart from the Ministry of Finance, who dealt with issues such as Special Aid and finance. The BECD's work involved managing the handover of the British military lands and assets; administering, developing, converting, and disposing of the lands and assets to civilian use; conducting negotiations over the delivery of British aid to help tide Singapore over the effects of the run-down; and using part of the aid for the retraining of redundant base workers. ${ }^{20}$ 
The conversion of the bases was a success and in both real and symbolic terms a major boost to Singapore's development. As early as October 1967, when the British Director of Lands and Claims in the Far East Command asked the Chief Surveyor of the EDB, "[W] hat Singapore was going to do with so much land - about 22 square miles", the latter confidently referred to a map of the island and "named a planned use for practically all establishments and installations". "This implies no haphazard takeover", the Director concluded, "they know where they are going!" ${ }^{21}$ The converted bases aided the creation or expansion of several major industries in the early I970s: the conversion of the naval dockyard at Sembawang into a commercial shipyard; of Changi airbase into a recreational resort and later an international airport; of part of the military facility at Seletar airbase into Singapore Electronic and Engineering Limited for repairing and overhauling electrical and electronic equipment; and of Blakang Mati into a tourist resort, renamed Sentosa. The BECD also planned the establishment of an offshore oil-drilling site off Sembawang, support operations at Loyang and industrial estates at Ayer Rajah and Telok Blangah; and the relocation of the University of Singapore from Bukit Timah to Kent Ridge. In the largest of the conversion projects at the naval dockyard, the British shipbuilding firm Swan Hunter provided vital technical and managerial expertise, as the Singapore officials "did not seem to have much grasp of the complexities of the commercialisation project". ${ }^{22}$

This is not to say there were no minor political or administrative hurdles in the process but, by and large, the transfer and conversion took place smoothly within the framework of Anglo-Singaporean collaboration. Both the British and PAP governments generally agreed on the terms of the transfer of the bases. In the same year that the withdrawal was announced, Britain proposed, and Singapore accepted, the working premise to transfer without charge to Singapore military facilities required for the republic's economy or defence, together with surplus items of non-operational moveable equipment. ${ }^{23}$ With up to a tenth of Singapore's land area becoming available for economic use, the British pull-out was a major catalyst for development in a land-hungry and rapidly developing state. The government's aim was not simply to prevent or absorb unemployment but to pursue a "positive, job-creation" strategy, based on state-driven industrialisation, so that "conversion planning can foster, and be integrated with, wider economic changes both nationally and globally" (Southwood I99I, I95, 200). At the same time, the conversion enhanced Singapore's industrialisation programme, because it coincided with the flow of international, particularly American, capital in the late ig6os to countries with cheap factory sites and low labour costs (Rodan I989). 
Less successful were the BECD's retraining programmes to help redundant base workers find new employment in industrial vocations, although retraining might have played a symbolic role in demonstrating Singapore's will and ability to industrialise and maintaining investor confidence. In a speech in 1968, Lee Kuan Yew explained why the redundant base worker had to be retrained:

It's no use giving the man five weeks' pay or one month's pay for every year of service - he will spend that and having nothing, he will be on my dole. What I want is to keep up the man's morale and self-respect. ${ }^{24}$

Here again, as in his stress on investor confidence, Lee emphasised the psychological; morale, he believed, was "three-quarters of the essence of the solution to the problems consequent on the reduction of the bases". ${ }^{25}$ This belief that the way to revitalise redundant workers was to provide them new skills rather than financial relief, was deeply rationalist.

The three-month long retraining programmes, modelled on those in Malta, were planned by the Organising Committee for the Training and Retraining of Redundant Base Personnel, established in April I968 under Ernest Wong, Director of Training in the BECD. The committee, like the BECD itself, was cross-ministerial in its work, coordinating the efforts of the National Trades Union Congress (NTUC), individual trade unions, EDB, and the ministries of education and labour. Discounting workers who were skilled or close to retirement, and those who could be re-employed from the naval dockyard to Sembawang Shipyard, the final figure of retrainees was 9-I0,000, most of whom were white-collar administrative workers or unskilled labourers. ${ }^{26}$ Some 3,309 out of the I०,००० retrenched workers at the Naval Base were re-employed by Sembawang Shipyard in 1968 (SPD 3 December 1968, 38).

Economist Lee Soo Ann viewed the retraining as "an exercise in sheer hope which might very well end in frustration" (Lee I97I, 6I). Here, the high modernist developmental project could not overcome individual resistance. The retraining was clearly inadequate in many cases for converting a white-collar worker into a skilled tradesman, as was highlighted by the government's plea for employers not to discriminate against retrained workers. Lee Kuan Yew stated in his memoirs that the retrenched were readily absorbed into factory work provided by the emerging industries in Singapore (Lee 2000, 73). But if this was true in a general sense, there were nonetheless very divergent experiences. Hwang Peng Yuan, the Head of Promotion in the EDB, reflected later that when "you get a 40-year-old shopkeeper who was already earning \$ I,500", "[i]t doesn't make sense for him to train as a machinist and start at \$500". ${ }^{27}$ In I97I, Hon Sui Sen admitted in Parliament that the redeployment of some retrenched 
base workers was difficult, while many older workers had not responded favourably to retraining, prompting the government to terminate the programme (SPD I7 March I97I, 759). There are no statistics on retraining, but a telling case was that of Lim Meng Jock, who joined the Naval Base as an accounts clerk in 1964, was retrenched in December 1968, and then completed two technical drawing courses. However, Lim did not become a tracer, but joined Sembawang Shipyard as a billing technician, another administrative position, before leaving to set up a catering business a few years later. The British withdrawal, he said, had "not much of an impact". ${ }^{28}$

The emphasis on technical and vocational education also shaped the nature of work for generations of young Singaporeans in the I970s and beyond. Following the announcement of the British pull-out, a new Technical Education Department was formed in the Ministry of Education (Singapore 1973). When Minister for Labour S. Rajaratnam spoke to the first graduating batch of 427 retrained base workers in July I968, he made no distinction between the retraining of redundant base workers and the new policy of promoting technical and vocational education due to the changing technological basis of the global economy, which was making white-collar and unskilled workers increasingly redundant. He spoke of the base workers as the "earliest victims" of this worldwide shift in the demand for labour, but noted their "good fortune" in receiving special assistance from the government to find alternative work. He warned white-collar workers that one day soon they might be replaced by machines and computers. ${ }^{29}$

Because it clearly aided Singapore's development, the British keenly endorsed the use of the Special Aid to finance and supply British expertise for the expansion of technical and vocational education. The former British army depot at Telok Blangah was converted into the fourth vocational institute in Singapore, which was capable of retraining 2,000 workers a year initially, but eventually doubled that number (Ministry of Education I969). The PAP government, with British assistance, was steadily transforming the economic, employment and social structures in Singapore. In I972, commenting on the development of technical and vocational education, the new British High Commissioner S. Falle surmised that "a major cause of the new release of disciplined energy which has produced this success was probably the galvanising effect on the Singapore government and people of the announcement of the withdrawal of British 'aid' in the form of the spending power of our armed services". ${ }^{30}$ With the reforms, the experiences and outcomes of work for young school-leavers with different skill-sets were to vary widely (Salaff I988). From the I970s, secondary, polytechnic and tertiary students with technical or vocational education were finding more highly paid jobs and more quickly than those trained more generally in the Arts. Males and English-educated University of Singapore students also did significantly 
better than their female and Chinese-stream Nanyang University and Ngee Ann Technical College counterparts (University of Singapore 1976, I980; Pang 1972, 1973, 1974; Eng 1974).

\section{The labour laws and 'new release of disciplined energy'}

The PAP government's ability to push through far-reaching social and economic policies came from the mandate it received in the 1968 general elections. Following the announcement of Britain's run-down, the leadership decided to hold early elections some seven months in advance for a strong mandate from the citizenry at this difficult juncture. The party won all the seats in Parliament and polled $86.7 \%$ of the vote, although this was helped by the decision of the opposition parties (except the Workers' Party) to boycott the polls. Foreign observers saw the early elections as an attempt by the PAP to obtain a popular mandate and push through a comprehensive economic package without having to spend time debating or consulting the people (Far Eastern Economic Review, henceforth FEER, 59 (9), 29 February I968, 360).

The companion policy to the educational reforms involved remoulding the character of labour, arguably the most comprehensive of the PAP's policies designed to maintain investor confidence. With complete control of Parliament, the PAP swiftly passed the Employment Act and an amendment to the Industrial Relations Act. Together with the Trade Unions (Amendment) Act, passed in I966, this trio of labour laws redefined the relationship between labour, employers and the state in post-pull-out Singapore. By making it mandatory for unions to hold a secret ballot before a strike decision could be taken, the Trade Union (Amendment) Act greatly undermined labour militancy, while a further amendment outlawed strikes in the essential services and sympathy strikes. The anticipated effects of the British withdrawal reinforced the government's rationale for passing the Employment Act. In July I968, when S. Rajaratnam explained the legislation as designed to help facilitate Singapore's future development, he framed the pioneer batch of retrained base workers as the vanguard of an adaptable national workforce spearheading the island's venture into manufacturing in the I970S. ${ }^{3 \mathrm{I}}$ The Act aimed to maximise the productivity of labour by increasing the number of working hours and cutting down on fringe benefits. Employees may not work overtime for more than 48 hours each month; may only obtain a maximum of one month's bonus per annum; may not obtain retrenchment or retirement benefits if they had not continuously served an employer for three or five years, respectively; and may only be paid double time, not triple time as previously, for work on a public holiday. The government also referred to the British withdrawal 
in justifying the need for the Industrial Relations (Amendment) Act. This legislation transferred significant powers to management, including the right to hire and fire, while trade unions were also prohibited from obtaining terms superior to those stipulated in the Employment Act in the "pioneer industries", to which the government was seeking to attract foreign investment.

The act of passing these pro-capital laws signified the progressive intentions of Singapore to international investors. They were intended to enhance Singapore's appeal as a site for foreign industrialists by shifting the basic labour framework from employee protection to employer protection (Tan I970, 25). Many workers and even labour leaders and PAP MPs were critical of certain provisions in the laws, although, significantly, they accepted them as necessary for the industrialisation programme..$^{32}$ The overwhelming electoral mandate won by the government was expedient, because it meant that labour MPs and activists could not simply reject the laws out of hand (FEER 6I (30), 25 July I968, I86). In Lee Kuan Yew's view, it was the acute sense of anxiety over "an economic collapse" arising from the news of the British withdrawal which led the workers of Singapore to accept the tough labour laws (Lee 2000, I08-9). Peter Vincent, President of NTUC, the dominant umbrella of unions in Singapore, warned retrained base workers in I968 that "the world does not owe us a living". He urged them to support the new labour laws and "contribute to the further development of Singapore" through manufacturing and tourism. ${ }^{33}$ An NTUC seminar in 1969 formalised this change of the trade union movement's role from being an independent player involved in "collective bargaining and traditional militancy" to playing an integrated 'symbiotic' role between government, management and labour in Singapore (Ministry of Labour I977b, 2).

The PAP government's belief in utilising the labour laws and retraining schemes, not only to equip workers with new skills but to create a new type of worker with a disciplined work ethic, was rationalist and quintessentially high modernist. The labour laws were not merely proscriptive but developmental in intent. The Employment Act aimed to "tighten labour discipline by providing against malingering and restrictive practices" (Ministry of Labour I977a, 2). The conversion of the naval dockyard into Sembawang Shipyard encapsulated this social engineering. Ship repair work in a commercial dockyard, unlike in a naval facility, now became a seven-day-a-week preoccupation, including overtime. ${ }^{34}$ When the 3,309-strong civilian workforce of the naval dockyard was hired en masse by the shipyard, the management cracked down strongly on work absenteeism, frequent sick leave and social gambling at the dockyard, as mandated in the Employment Act (Chew 1998). As a former BECD official reflected on the discursive language of the new industrial economy, base workers "could no longer adopt a carefree or 
lackadaisical attitude to their work as they would have to meet completion time of vessels" (Leong unpublished). The Barisan Sosialis alleged that "[o]n the excuse of fighting unemployment consequent on the sham 'British withdrawal', workers are heavily oppressed and exploited" (Plebeian IOI, 9 January I97I, 2).

Many former base employees keenly felt this dramatic shift in the culture of work at Sembawang Shipyard, although few understood the significance of the labour laws at the time. The amount and pace of work changed markedly along with the surge in the volume of ships calling at the shipyard. While working in the naval dockyard, Lim Shee Chee's father, a fitter, would cycle to work in the morning, spend much of a typically slow day drinking coffee, cycle home for lunch, before returning to his workplace; he would be home by $4.30 \mathrm{pm}$. "That's the life of a servant of the British Empire", Lim remarked. ${ }^{35} \mathrm{John}$ Ng, a policeman at the Naval Base who retained his job at the shipyard when the British left, commented that there was not a single oil spill in the dockyard and workers could "shake a leg" during lull periods. ${ }^{36}$ But at Sembawang Shipyard, Ho Shee Lim, a tradesman, felt that "every day was a mad rush", as workers now had more challenging targets to meet. ${ }^{37}$ Balachandran Nair, a mechanic at the naval dockyard who continued working in Sembawang Shipyard, observed that "work in the shipyard was a tough life", "miles different" from that in the dockyard. As security guards increasingly cracked down on social gambling during working hours at the shipyard, the corporate focus on profits and individual betterment filtered down to many workers. "You sweated to get [a] bonus in Sembawang Shipyard", Nair told me, adding, "Only thing good in Sembawang Shipyard is you get promoted if you worked hard".$^{8}$

Work in the shipyard also became more stressful because it was much more regulated. Along with the increased volume of work came changes in the supplement of rules for Sembawang Shipyard workers. Getting sick leave now became more difficult, at least in the eyes of the workers. In Nair's account, the medical centre in the Naval Base was always full on Monday, as the British did not interfere with the workers' entitlement to I4 days of sick leave per year. "If the British were still here", Nair concluded, "Singapore would not be what it is today". ${ }^{39}$ John Chai, a tradesman for steel fitting in Sembawang Shipyard, stated that as the amount of work increased after the commercialisation of the dockyard, the hazards of working onboard ship were greatly magnified. As one could get seriously hurt by the release of toxic gas, an explosion or fire, objects falling from above, or slipping on a wet surface, he had to be "Io०\% alert" at work. As he felt that the doctors in the shipyard were reluctant to grant medical leave unless one was seriously sick, Chai took care of the minor bruises and cuts he suffered at work by continuing to work and seeing a Chinese physician for treatment, or by self-medicating. Of the injuries, 
Chai observed, "It's nothing, [you] just have to take care," adding, "That's the way".$^{40}$ Chai's remarks indicate the extent to which former base workers were socialised into the post-pull-out industrial economy of Singapore.

In its review of Singapore in I969, in the middle of the run-down, the British High Commission labelled the year as one of "non-stop action". This was the "year of the Beaver", with burgeoning construction work in Singapore - on "hotels, housing, office-blocks, factories, container ports, schools power stations, flyovers, community centres" - making it truly a "workers' republic". No small thanks because, the report concluded in self-gratifying fashion, Singapore had responded robustly to the shortened timeline for Britain's withdrawal from the island. The writer of the report was Arthur de la Mare..$^{4}$

\section{From 'Little Britain' and 'Kochu Kerala' to modern Singapore}

Mass redundancy due to the run-down was a central concern for the Singapore government. In fact, most blue-collar workers of the naval dockyard were absorbed into Sembawang Shipyard, while the experiences of white-collar employees, unskilled workers and service providers varied, depending less on the pull-out per se than on local factors such as one's age, education, family composition, and social networks. The father of Lam Chun Chew, a senior clerk at the Naval Base, was retrenched, but this was the prelude to a 'golden handshake', as he received a five-figure redundancy benefit, found work in private firms and retired comfortably several years later. "I really believe you have picked a wrong candidate to relate to you of my father's retrenchment story", Lam told me, "simply because our situation was very different from others". $4^{2}$ The grandmother of George Annadorai, who worked as an amah for a British family in RAF Seletar, also received a "handsome offering" when they departed. She was elevated from domestic servant to landlady overnight, using the money to build wooden houses in Jalan Kayu village just outside the base, which she rented out to villagers. ${ }^{43}$

Another amah, Tan Geok Hak, was not so fortunate. Working for the family of a British officer in Holland, the withdrawal cut her source of income without providing for any redundancy benefit. She became a home-based, piece-rated worker in Singapore's informal economy, sewing clothes and making paper bags for pressure lamps. Many older Chinese amahs, she said, "retired" after the British withdrawal, an outcome which was less a voluntary than an enforced one. ${ }^{44}$ For Song Koon Poh, the son of a clerk working in the British Ordnance Depot, the run-down was a life-changing personal experience. Following his father's retrenchment, Song had to forgo his opportunity to pursue his pre-university education and venture into the workplace to support the family, thus 
fulfilling the Chinese tradition of family-based self-help. He joined a shipping company as an assistant boarding officer in I97I at the age of I7, benefiting from the boom in Singapore's marine industry. His sister, like Tan, also contributed to the household by sewing clothes, for which she was paid by piece. As Song reflected: "We struggled as a family during the years just before the British pulled out and immediately after". ${ }^{5}$

Just as crucial as the economic consequences was the social impact of the British run-down. Its role as a catalyst was also to extend the political economy of life in Singapore into spaces previously under British military control. On the one hand, the British bases were 'Little Britains' in the cultural and economic senses, self-contained enclaves governed by the British which "stood quite apart from the development going on in other parts of the Island" (Lim I974, 23, 58). On the other, the military facilities also developed a unique, semi-autonomous 'base culture' owing both to the presence of British power and the Asian labour force residing in them. The Naval Base, for instance, was known to the locals as 'Kochul Kerala' or 'Little Kerala', after the rich cultural life of the large Malayali population living in the base, expressed in their religious and cultural organisations and activities (Liew 2006).

Socially and culturally, for many former base employees and residents, the British pull-out constituted the end of an era. Life in a British base was shaped by the unique combination of Western modernity and vernacular culture. In the locals' perception, the base represented the best of two different worlds: the kampong with its unauthorised housing, basic amenities but close community bonds, and the Western-style estate with its permanent housing, material comfort and modern amenities. In the Asian quarters in the Naval Base bounded by Kowloon, Delhi and Madras roads, the neighbours knew one another as far as 200 metres away, while adults and children of different ethnic groups intermingled freely. As John $\mathrm{Ng}$, the naval policeman in the base who learnt Tamil from his neighbours and friends in the base, recalled, "You could see an Ah Seng, a Muthusamy and an Ahmad together" ${ }^{46}$ For Cramon Chenteley, whose father was a fitter in the Naval Base, the area was not only "a protected place", fenced up and closely guarded, but also a "kampong-like" environment where school-going children and youths were "free to play". Yet, he was also happy that he did not have to endure water rationing while living in the base (they had piped water), or use a pail toilet (they had water closets) or an oil lamp (they had electricity).47

When the bases began to be run down, however, the residents began to experience the powerful integrating pull of the high modernist state and economy of Singapore. Here was 'conversion' of not only the uses of physical assets but also social and economic roles. Where once the rent in the base had been heavily subsidised and the utilities free, the residents now had to pay for the use of water and electricity. 
As Vanessa, John Ng's wife, a Punjabi, remarked, "Nothing is free after the British withdrawal". ${ }^{8}$ Balachandran Nair, who moved out of the area when he got married and later moved into a Housing and Development Board (HDB) flat in Ang Mo Kio estate, lamented, "You can't get that life [in the Naval Base] back". ${ }^{49}$ For those still living in the base, as more of their neighbours left, as George Annadorai recalled of RAF Seletar, there was an obvious 'slow death' to the social and cultural life of the community..$^{\circ}$ The tipping point for many residents was when they moved out of the bases in the early I970s as the British forces finally left. In the new HDB public housing to which many of them moved into, they encountered the lack of social and community interaction which many other Singaporeans had experienced a decade earlier: locked doors and a life centred around the demands of work, away from one's residence. Like many former Naval Base residents, John Chai, the tradesman, moved into the Jurong Town Corporation flats built for workers in Sembawang. He hardly knew his neighbours, but eventually understood why: he typically left for work around 5 plus in the morning and returned home only at IO-II pm after working overtime. ${ }^{\mathrm{I}}$ As full-fledged worker-citizens of the post-pull-out state, the lives of Chai and other former base workers were being drawn into the emerging high modernist structures of Singapore, as the island became increasingly connected to an international web of industrial capital in the I970s.

\section{Conclusion}

In 1974, Lee Kuan Yew thanked Her Majesty's Government for the 'breathing space' British forces had provided for Singapore's development..$^{52} \mathrm{He}$ had much to be thankful for: the accelerated British withdrawal was not only the final chapter of decolonisation in Singapore, but also the first step in the independent city-state's growth. The catalyst, which began as a crisis for both Britain and Singapore, was forged at the intersection of imperial and national policies and enabled by the combined agency of the two parties. The British aim was to achieve successful decolonisation by continuing to encourage Singapore's development during the withdrawal. This meant providing aid and technical expertise to Singapore and handing over the bases promptly for its defence and developmental uses.

British policy coincided with the high modernist projects pursued by the PAP government, a programme that was also based on the post-war colonial blueprint. This programme sought to protect investor confidence in Singapore in both concrete and symbolic ways, as envisaged by Lee Kuan Yew and Goh Keng Swee. Despite de la Mare's accusation 
of a British 'handout', he admired the development of Singapore in the late I960s and recognised the role played by the run-down; if anything, he was overly pessimistic about the role of his British colleagues in negotiating the terms of the handover. In fact, as officials in both countries realised, the economic and strategic interests which Britain wanted to safeguard in a smooth pull-out would at the same time be served by facilitating the expansion of the Singapore economy. De la Mare's view of the Special Aid as a "bribe" and "sweetener" was not so much wrong as not fully putting in context the close collaboration between Britain and Singapore in dealing with the effects of the run-down. The 'Malta precedent', which Singapore drew on for its negotiations with the British and for addressing the effects of the withdrawal, was another slice of the connection between Singapore and another part of the Commonwealth.

The programmes of national development and social engineering, enabled by Anglo-Singaporean collaboration during the withdrawal, spurred the transformation of the island state into an international industrial hub in the I970 and elevated it to a new place in world history. Rationalist projects to commercialise the military facilities, accelerate construction works, expand technical and vocational education, retrain redundant base workers, and forge a disciplined labour force both provided the raw material for Singapore's growth and mobilised the people into their new role as members of a new 'workers republic'. These were either ongoing projects now being systematically expanded in the context of a 'national crisis' or planned ones which were quickly brought forward. Not all the projects were entirely successful: the retraining was often inadequate and naturally invoked the resistance of middle-aged clerical workers, while the reform of technical and vocational education was to further divide the experiences of workers according to skill as well as language and sex. Fast pace of work, systematic routines and stress now characterised the working lives of many former base employees re-employed in the newly commercialised plants of production. Whatever their effects, the projects collectively defined the political economy of work in Singapore into the I970s and beyond.

Finally, the effects of a decision made in Britain were deeply felt at the local level, as the lives of base workers and residents were 'converted'. This encapsulated strikingly James Scott's point that high modernism sought not only to transform nature but also human nature (Scott I998). During the PAP era from I959 onwards, the British ordnance depots were the remaining semi-anachronistic spaces in the city-state which, while in their own ways modern, existed largely outside the well-regulated structures of the newly emerging state that was predominant on the remainder of the island. The base residents, used to the unique blend of the material comfort and vernacular base culture of the 'Little Britains' and 'Kochul Kerala', found their own identity dramatically redefined by the 
scope of transformation during the run-down. Formerly 'servants of the British Empire', they were now being socialised as worker-citizens of the post-pull-out state. When they moved out of the bases, often to public housing estates close to their workplaces, the sense of community and neighbourhood which had for a decade shielded them from the political economy of industrialisation gave way to a closely integrated relationship with the state and international capital. It was, naturally, the pull-out which enabled the final phase of the modernisation process the British regime had first started a generation earlier at the end of the Pacific war to be completed at the bases themselves. Wan Chan Peew, a clerk working at the Naval Base, was re-employed in the same vocation at Sembawang Shipyard. Recalling the conversion of the bases, the move of many base residents into HDB flats and the increase in his working hours from 36 to 44 per week, he observed, "It was such a buzz - rather than the pull-out!" 53

\section{Notes}

I This time-frame refers to the schedule planned in 1968; in fact, smaller British forces remained in Singapore until March 1976.

2 FCO 24/IoIg Telegram from Arthur de la Mare to Alec Douglas-Home, 3 November I97I.

3 FCO 24/62, Note of a Conversation at the Commonwealth Secretary's Luncheon for Mr Lee Kuan Yew on 16 January 1968.

4 FCO 24/I86I, Memo on ANZUK Real Estate by P. G. de Courey-Ireland, South West Pacific Department, Io October I974.

5 FCO 24/62, Letter from Lee Kuan Yew to Harold Wilson, I8 December I967.

6 FCO 24/62, Transcript of Interview, 'Prime Minister Lee Explains his Difficulties', I5 January 1968.

7 FCO 24/62, Transcript of a Press Conference Given by the Prime Minister Mr Lee Kuan Yew at the City Hall, 9 January 1968.

8 FCO 24/62, Telegram from British High Commission to Commonwealth Office, 5 January I966.

9 FCO 24/888, Telegram from Arthur de la Mare to Roy Mason, President of the Board of Trade, 29 January 1970.

IO FCO 24/186I, Disposal of Service Assets in Singapore, 29 August I974.

II FCO 24/75, Note by the Ministry of Defence on Defence Lands and Fixed Assets in Malaysia and Singapore, 9 November 1967.

I2 FCO 24/II4, Opening Statement by Mr Hon Sui Sen, Leader of the Singapore Delegation, Annex B, 8 March ig68.

I3 Radio Corporation of Singapore, audio recording titled 'Interview with Manual Pillay, Economic Development Board', 6 December 1967.

I4 Author's interview with J.Y.M. Pillay, 26 November 2009.

I5 FCO 24/75, Extract from Meeting in Singapore, I2 October 1967.

I6 Radio Corporation of Singapore, audio recording titled 'Interview with Manual Pillay, Economic Development Board', 6 December I967.

I7 FCO 24/327, Telegram from British High Commission to Commonwealth Office, 2 March 1968. 
I8 FCO 24/888, Telegram from Arthur de la Mare to Roy Mason, President of the Board of Trade, 29 January I970.

I9 FCO 24/888, Letter from Roy Mason, President of the Board of Trade, to Judith Hart, Minister of Overseas Development, 24 February I970.

20 Ministry of Culture IIo/68, Memo from Secretary to the Prime Minister to All Permanent Secretaries and Heads of Departments, 8 February 1968.

2I FCO 24/75, Extract from Presentation by Director of Lands and Claims, Far East Command, i3 October I967.

22 FCO 24/II4, Negotiations on Aid with Malaysia and Singapore, 8 March I968.

23 FCO 24/II4, Note by the British Delegation on the Transfer of Lands and Fixed Assets, Annex C, 8 March 1968; and Note by the British Delegation on the Transfer of Moveable Assets, Annex D, 8 March ig68.

24 FCO 24/62, Transcript of a Press Conference Given by the Prime Minister Mr Lee Kuan Yew at the City Hall, 9 January 1968.

25 OD 39/8, Letter from Lee Kuan Yew to Reginald Prentice, Minister for Overseas Development, I5 December I967.

26 Radio Corporation of Singapore, audio recording titled 'S. Rajaratnam at Graduation Ceremony of Ist Group of Trainees for Redundant Base Civilian Workers', 29 July I968.

27 Oral History Centre (henceforth $\mathrm{OHC}$ ), interview with Hwang Peng Yuan, 29 August 2002-4 April 2003.

28 Author's interview with Lim Meng Jock, I7 November 2009.

29 Radio Corporation of Singapore, audio recording titled 'S. Rajaratnam at Graduation Ceremony of ist Group of Trainees for Redundant Base Civilian Workers', 29 July I968.

30 FCO 24/I58, Telegram from S. Falle to Michael Walker, Overseas Development Administration, 2I February 1972.

3I Radio Corporation of Singapore, audio recording titled 'S. Rajaratnam at the Graduation Ceremony of Ist Group of Trainees for Redundant Base Civilian Workers', 29 July I968.

32 OHC, interview with Seah Mui Kok, 6 July I988, I7 June I994.

33 Radio Corporation of Singapore, audio recording entitled 'S. Rajaratnam at the Graduation Ceremony of Ist Group of Trainees for Redundant Base Civilian Workers', 29 July 1968.

34 Radio Corporation of Singapore, audio recording titled 'Conversion of Naval Base Swan Hunter Group', i8 June ig68.

35 Author's interview with Lim Shee Chee, 4 December 2009.

36 Author's interview with John Ng, I6 December 2009.

37 Author's interview with Ho Shee Lim, I5 December 2009.

38 Author's interview with Balachandran Nair, I7 December 2009.

39 Author's interview with Balachandran Nair, I7 December 2009.

40 Author's interview with John Chai, 28 December 2009.

4I FCO 24/875, Singapore: Annual Review for I969, 5 February 1970.

42 Author's email correspondence with Lam Chun Chew, I3-I7 November 2009.

43 Author's interview with George Annadorai, ro December 2009.

44 Author's interview with Tan Geok Hak, I7 December 2009.

45 Author's email correspondence with Song Koon Poh, 4-6 October 2009.

46 Author's interview with John Ng, I6 December 2009.

47 Author's interview with Cramon Chenteley, Io December 2009.

48 Author's interview with Vanessa Ng, I6 December 2009.

49 Author's interview with Balachandran Nair, I7 December 2009.

50 Author's interview with George Annadorai, Io December 2009.

5I Author's interview with John Chai, 28 December 2009.

52 FCO 24/I86I, Conversation with Mr Lee Kuan Yew, 29 November I974.

53 Author's email correspondence with Wan Chan Peew, Io January 20 Iо. 



\title{
11 Bringing the International and Transnational back in: Singapore, Decolonisation, and the Cold War
}

\author{
S.R. Joey Long
}

In recent years scholars of Singapore's history have called for the historiography of the island to be reconfigured. Reviewing a wide range of studies on Singapore's history and exploring ways to ask new questions about the island's past, historian Albert Lau has proposed that historical narratives about the country should be contextualised more broadly. One alternative way of narrating Singapore's history, he suggests, could be "within the framework of regional and world history" (Lau 2004: 50-5I). Like Lau, Derek Heng, Kwa Chong Guan, and Tan Tai Yong have made a similar appeal for the Singaporean historical narrative to be rethought in a wider context. Eventually collaborating to write such a story, they focus in their jointly-authored book on the larger regional and international economic and strategic environment that has affected Singapore's development since the fourteenth century. International actors, global trade flows, and regional players have shaped the course of Singapore's historically contingent and non-preordained journey towards becoming a global city-state (Heng, Kwa \& Tan 2009). Finally, another collection of articles edited by Syed Muhd Khairudin Aljunied and Derek Heng have likewise reframed the historiography of Singapore, using comparative and transnational perspectives to rewrite the island's history in a broader and more cosmopolitan context. The stimulating and thought-provoking essays in that volume ask new questions and generate new insights into how trans-regional linkages and concerns about global economic competition ultimately shaped histories and identities in Singapore (Heng \& Aljunied 2009). What ties these recent historiographical trends together is a profound recognition that insular narratives which privilege the local are no longer intellectually satisfying. Given the fact that Singapore's economic, demographic, and intellectual development has historically not been immune to forces unleashed by changing societies elsewhere in the world, these recent appeals for a reorientation of Singaporean history towards broader contexts and themes could not be timelier. A yawning gap needs to be bridged between lived experience and historical scholarship. As the island's longstanding cosmopolitanism has rendered its 
society and economy open to external influences and trends, it is important to examine how Singapore's connections to these international and transnational movements and developments have shaped its history (Harper I997). The notion of an island entity - geographically situated at one of the most important and strategic economic crossroads in the world - that is impervious to external influences and developments is conceptually limited and historically unrealistic. If historians studying the island's past adopt an analytical focus that is narrowly national and insular, they will miss much that has had an impact on Singapore. Conversely, to comprehend the multiple dimensions of Singaporean life, it is necessary to enmesh Singaporean history with other histories. Local history should be investigated in the context and light of other historical events taking place across the globe.

An earlier generation of astute historians working on the period prior to World War II were indeed sensitive to the connections of the island with broader global trends. For example, there is Wong Lin Ken's work on how the opening of the Suez Canal and global economic developments profoundly affected Singapore's economic growth during the nineteenth and early twentieth centuries (1978). Wang Gungwu's writings on Singapore's demographic history, which is intimately connected to Chinese migration patterns, also comes to mind (2003). And one is reminded of Anthony Milner's scholarship on the movement of ideas, namely Islamic doctrines, from the Middle East to porous Singapore, which made the island "an Islamic centre of high reputation" before the turn of the twentieth century (I995: 159). Not only were these intellectuals aware of the wider dimensions of Singapore's history - they clearly understood that commerce, migrants, and ideas crossed national boundaries.

Although much has been written about the history of decolonisation in Singapore in the twentieth century, tracing the local anti-colonial movement's campaign of resistance and defiance against the colonial order, there remains a telling oversight in the conventional literature's analytical focus. The political, diplomatic, and ideological forces that were unleashed by the Cold War and which intersected with Southeast Asia's and Singapore's decolonisation experiences are hardly taken into account. Ostensibly following the trend blazed by John Smail (I96I) to write histories that are 'autonomous' of external prerogatives and perspectives, the conventional studies tend to confine their narratives to events and personalities within the fledgling nation-state. In such studies, the latter is uncritically laid out as a self-contained unit where nationalists heroically battled and triumphantly overcame colonialists as well as communists and communalists to establish a non-communist and multiracial postcolonial state (Bloodworth I986; Clutterbuck I984; Drysdale I984; Fong I980). Such accounts, of course, serve their nation-building purposes. 
But they have been rightly criticised for being overly didactic and whiggishly teleological. The so-called 'Singapore Story' that has been propounded by the victors also blocks out and suppresses other histories (Heng \& Aljunied 2009; Hong \& Huang 2008). Among the histories that have been overlooked is Singapore's connection to the Cold War during the years of decolonisation.

The period from 1945 through 1965 was arguably both the best of times and the worst of times for peoples in Southeast Asia. Many within the sub-region looked forward to a new order following the end of World War II. With the colonial empires in disarray, national liberation and self-determination were eagerly anticipated. As Southeast Asians organised and tussled to formulate their competing visions of how their fledgling post-colonial states should be established, the Cold War started. If "war makes states," as American scholar Charles Tilly once pointed out, so did the Cold War (Tilly I985: I70). That global conflict has affected each of the post-war Southeast Asian states (Goscha \& Ostermann 2009). On Singapore too one can detect the footprints left behind by Cold Warriors and other external actors who sought to push their agendas and preserve their interests on the island.

Motivated by their respective communist and liberal-capitalist ideologies and by the fear of losing out to their adversaries, the Soviet Union, China, and the United States all intervened in the late-colonial world to ensure that decolonisation proceeded in a way that advanced their interests. Apart from directly intervening in the late-colonial world, the major powers also intervened by proxy. International organisations such as labour groups sponsored by Moscow and Washington were further actively involved in seeking to sway peoples within the late-colonial and post-colonial states into supporting the respective ideological camps (ibid; Westad 2005). While the Cold War adversaries tangled, the colonial powers were also making their moves. They were not hurriedly retreating without either putting up a fight or ensuring that their interests and informal influence were protected in what were progressively becoming their former colonies (Louis \& Robinson 1994). Research has shown that Southeast Asians were not unaware of these manoeuvres and counter-manoeuvres. Some even courted great power assistance in their campaigns against their international adversaries, the colonial powers, and their domestic rivals (Goscha \& Ostermann 2009). National histories that privilege only the heroics of the local tend to neglect such stories. The prevailing historiography of Singapore has certainly not brought these histories into sharp focus.

By locating Singapore in that complex world where the Cold War and decolonisation intersected histories that have been previously overlooked can be reassessed. Such an approach could clearly contribute to a richer understanding of Singapore's past. As extant stories become 
defamiliarised, unpredictable, destabilised, and seen in a new light, newfound inquisitiveness about Singapore's history could also be stimulated. Historical narratives about Singapore might then rekindle citizens' engagement of a field of study that has been rendered trite by the influence of national education (Hong \& Huang 2008). Such histories would further speak to contemporary concerns about the opportunities and stresses of globalisation, about how the nation state is implicated and entangled in the transnational flow of ideas, capital, goods, and human traffic that connect the island state to other parts of the world.

In the pages that follow, this chapter expands on the call to internationalise and trans-nationalise the history of Singapore. The aim here is not to completely subvert 'Singapore the nation-state' as a category for analysis. The chapter aims instead to broaden the boundaries of historical investigation and to re-examine the cosmopolitan island's connections to international politics, transnational movements, and global trends. Specifically, this paper includes but also looks beyond the roles played by domestic actors in shaping the island's affairs. It seeks to evaluate the actions and impact of colonial actors, a non-governmental organisation and external actors on Singapore. It analyzes how British strategic considerations, members of a labour international, and American and Taiwanese Cold Warriors influenced decolonisation, provoked domestic conflicts, and contributed to the political process in Singapore. By embarking on such analyses, the traditional themes covered in the history of diplomacy, labour, and politics in Singapore are set in a wider context and hopefully enriched.

\section{British Cold War policy and constitutional reform in Singapore}

The impact of British Cold War policy on Singapore's constitutional history remains an interesting puzzle that has yet to be satisfactorily resolved. In 1954, Britain joined the Southeast Asia Treaty Organisation (SEATO). London wanted to collaborate with other powers such as France and the United States to thwart communist expansion into Southeast Asia. Britain's participation in the alliance, however, intertwined SEATO's concerns with Singapore's affairs. SEATO burdened Britain with demands such that it had to tread carefully with regard to political change in Singapore during the I950s. If Britain hastily granted more political autonomy to Singaporeans, this could adversely affect its ability to use the military installations on the island for SEATO military operations. However, if London retarded decolonisation to secure the bases for SEATO operations, it would risk incurring the ire of local nationalists. This perplexing dilemma with which British planners were confronted has not been explored in substantial depth in the literature. Certainly, writers have alluded to SEATO's influence on the British decision to reject Chief 
Minister David Marshall's demands for greater self-government during the 1956 constitutional talks. But how central was SEATO to the British decision-making process? This has been not been clearly ascertained. ${ }^{\mathrm{I}}$ Also puzzling are the different attitudes adopted by the British towards Marshall and his successor, Lim Yew Hock. If the British were tough on Marshall during the 1956 constitutional talks, they were more conciliatory towards Lim during the 1957 negotiation. What changed? SEATO certainly remained in operation throughout the period. The Harold Macmillan administration also intensified its support for the alliance and endeavoured to strengthen SEATO's deterrent capacities by upgrading the bases in Singapore for nuclear operations (Jones 2003). Yet the British ultimately entertained Lim's demands for more political autonomy. Scholars have argued that it was Lim's strident anti-communism that won Britain's confidence (Drysdale I984). This contention has merit. But were there other considerations? As in Marshall's case, factors beyond the local would weigh heavily on the British decision to compromise. The outcome and repercussions of the October I956 Suez crisis, in particular, would sway British minds. In sum, the subject explored here suggests that it is by locating the two historical episodes in their wider regional and international contexts and showing how the external intersected with the domestic that the British decisions during the 1956 and 1957 constitutional talks become easier to understand.

Formed in September 1954, SEATO was a product of the Eisenhower administration's containment policy. It was an institution of collective defence, established to defend the non-communist Southeast Asian states from communist aggression (Dingman 1989). ${ }^{2}$ Despite Britain's initial misgivings about the lack of Asian representation in the alliance, it joined SEATO because it believed the organisation could help defend Malaya and Singapore against communist aggression and enable the burden of defence against communism in the sub-region to be shared among a larger pool of actors. ${ }^{3}$ Through Britain's membership in the alliance, however, Singapore was entwined in SEATO's military operations. When SEATO strategists crafted defence plans from 1956 onwards, British representatives agreed to designate Singapore as one of the key operations and logistics hub from which the alliance's forces could be deployed to deal with a communist assault into Southeast Asia. So important was the island to these plans that British officials mused that "if Britain surrendered the Singapore bases, S.E.A.T.O. would collapse." 4 As British planners were determined to adhere to their alliance commitments, they sought to ensure that the island's bases would remain under firm British control. ${ }^{5}$ But developments in Singapore seemed to threaten that aspiration. Agitation for political autonomy was becoming increasingly vociferous, and the recently-elected local administration did not appear capable of helping the British preserve the security of the bases. 
To defuse hostile sentiments against colonial rule, the colonial government in Singapore had agreed to accept the reformation of the local constitution in I954, granting Singapore greater internal self-government. Elections held under this constitution in I955 eventually paved the way for a local government to be formed. The new administration, which was led by David Marshall of the Singapore Labour Front, oversaw most domestic matters, while the British retained control of foreign affairs, internal security, and external defence. A deal was struck, nevertheless, for both sides to negotiate further for greater internal authority - principally domestic police powers - to be handed over to the local government. The talks were scheduled to be held in London from late April through May 1956 and the Singapore delegation would be led by Marshall.

The British, however, were becoming increasingly disillusioned with Marshall and the pace of the political reforms. Military officers in Singapore, in particular, balked at the threat the political reforms were posing to their capacity to meet Britain's SEATO obligations. The Marshall administration's ostensible inability to deal decisively with the widespread riots that erupted in I955 distressed officers such as General Charles Loewen of General Headquarters, Far East Land Forces (GHQFELF). The mayhem, which shut down public services and blocked roads across the island, demonstrated that social disorder in Singapore could isolate the British military installations and cripple British regional military operations. As the constitutional talks between Marshall and Colonial Secretary Alan Lennox-Boyd approached, Loewen pointedly reminded London that Britain had commitments to regional institutions such as SEATO. Any political concessions granted Marshall must therefore not weaken domestic security in Singapore and undercut Britain's ability to support the alliance. ${ }^{6}$ For members of the British Defence Co-ordination Committee Far East (BDCCFE), social order would be secured and regional responsibilities advanced if the British right to permit allied forces from organisations such as SEATO to use the bases, the British entitlement to control lands for military purposes, and the British control of internal security were retained.7 Likewise, the top brass in London weighed in with the same stipulations. ${ }^{8}$ In March 1956 , the service chiefs further stated that, because Singapore was critical to the success of SEATO's military operations and the defence of British interests in Southeast Asia, British negotiators should not hand domestic police powers over to local politicians. Such a move might undermine the security of the bases and hinder Britain's capacity to meet its regional treaty obligations. ${ }^{9}$

Marshall, of course, was unaware that London's position on internal security had stiffened when he declared in the Legislative Assembly in April I95 6 that he would resign if the Colonial Office refused to surrender domestic police powers to the elected government. ${ }^{10}$ The chief minister 
evidently saw external and internal security matters as administratively and operationally distinct, and was prepared to permit the British to oversee the former while insisting locals handled the latter. But British officials viewed the two as inextricably linked. If the security of the bases was not adequately protected, London's capacity to back SEATO would be severely undermined. With the Cabinet endorsing the military's counsel that authority over internal security should remain under British control and with Marshall holding firmly to a converse view, the stage was set for the constitutional talks to collapse. ${ }^{\text {II }}$

It is by situating the April through May negotiations in the wider context of British Cold War policy that the outcome of the talks and Marshall's reaction to the outcome become more comprehensible. Adhering to his government's policy, Lennox-Boyd refused to turn internal security over to Marshall. With the colonial secretary conceding nothing, the chief minister returned to Singapore from London empty-handed. Marshall finally did understand, though, and with some bitterness, that the British viewed internal and external security matters as closely interlinked. Speaking in the Legislative Assembly on 6 June, Marshall resentfully charged that the British had refused to surrender their police powers because they wanted to continue to oversee the security of the bases and ensure that they were able to honour their obligations to SEATO. Progress towards greater self-government, Marshall angrily proclaimed, had been sacrificed as "a live offering to their god of brass, S.E.A.T.O." I2

International and regional politics, therefore, were very much at the core of Singapore's decolonisation story. The reasons why constitutional reform in Singapore did not evolve to the next stage in 1956 are better understood when the island's constitutional history is set in the wider context of the Cold War and British strategic priorities. Britain's Cold War concerns and commitment to SEATO had evidently affected political developments in Singapore. Historical narratives that focus only on local struggles and contexts tend to neglect these larger factors that affected Singapore's decolonisation experience. Indeed, if historical knowledge on why Marshall failed to make a breakthrough in the 1956 constitutional talks is enhanced when the context is widened, one's understanding of his successor's - Lim Yew Hock's - success in obtaining concessions from the British can be further improved when the international context is incorporated into the analysis.

Unlike Marshall, who kept his word and resigned after the failed talks, Lim dealt with a less confident Britain. Lim confronted a British government that was keen to restore its moral authority after participating in a fiasco in Egypt. In October 1956, the British joined France and Israel in attempting to seize the Suez Canal. Global opinion, however, was against them. They were ultimately forced into a humiliating retreat, but not without suffering serious damage to their international standing. 
In Singapore, local politicians angrily denounced Britain's imperialist actions. It seemed that Britain remained an unreconstructed imperialist and was not sincere about progressively devolving power to locals. ${ }^{13}$ To Colonial Office officials who were most sensitive to colonial opinion, Suez was a severe setback. If Britain was no longer viewed as an enlightened colonial power that was preparing its colonies for eventual autonomy, British colonial policy would be treated with derision. Instead of an orderly transfer of power to those who the British trusted, militant groups might become more influential, hijack the anti-colonial movement, and force the British out. Lennox-Boyd - mindful of such eventualities - lamented the fact that the Suez debacle had undercut much of the goodwill that was generated by Britain's widely-publicised declaration to grant Malaya self-government. The same official who rebuffed Marshall now advised that Lim's requests should be accommodated at the next constitutional talks. If the British alienated and undermined politicians such as Lim, Lennox-Boyd reasoned that extremists and communists might exploit Lim's failures and the anti-colonial climate to enhance their political influence. With hostile forces in power, Britain's unhindered use of its military installations on the island would be complicated. Significantly, Lim made British officials aware of that possibility in a private meeting in August. The British consequently decided that they would prefer to deal with Lim. He could be trusted as he had shown thus far that he was not militantly anti-British. Lim, furthermore, had been firm in suppressing agitators in Singapore. The more bellicose types, conversely, were less likely to consent to British bases remaining on the island in exchange for political concessions. ${ }^{14}$

Colonial officials, therefore, seriously re-examined Lim's plan, which he had floated in August I956, to break the deadlock between the two sides. The contentious issue remained control over internal security. Lim resurrected Marshall's proposal, which Lennox-Boyd had earlier rejected, to introduce a tie-breaker Malayan vote into a security council that oversaw domestic security. As the Malayan representative would most likely support Britain in prosecuting militants in Singapore, the British government should have little reason to worry about the safety of its bases. ${ }^{15}$ Although military officials became apprehensive about the deal and continued to advise caution, they finally concurred with the Colonial Office's recommendation to compromise. ${ }^{16}$ Power was being transferred to friendly elements in Singapore, after all. If Britain showed itself to be a progressive colonial state, it could nurture amiable relations with Singaporeans who would be less likely to attack the Britain bases and cripple British regional operations. Still, the service chiefs would take no risks. They demanded that control of the bases should be secured from Lim "as of existing right" rather than via a treaty. This arrangement would enable Britain to continue to use Singapore for SEATO and other 
regional defence activities. Their demands were communicated to the Colonial Office, which was, in turn, requested to convey them to Lim. ${ }^{\text {I7 }}$

As the Lim government had neither the wish nor the capacity to manage external security, the talks in March and April I957 went very smoothly. The British agreed to Lim's proposal to form a committee comprising an equal number of British and Singaporean representatives plus one Malayan to manage internal security. Amendments would be made to the constitution, granting Singapore complete internal autonomy. Britain would continue to oversee external security and would acquire the right to occupy and use the bases to meet its regional treaty obligations. A balance was finally struck - an arrangement that accommodated local political aspirations as well as British ambitions to exploit Singapore in order to advance their regional commitments. ${ }^{18}$

What the preceding narrative suggests is that the Cold War, SEATO, the Suez crisis, and the desire to maintain informal influence in the post-colonial state were critical factors that weighed heavily on Britain's dealings with local politicians during the I950s. Lim, of course, played his part by exploiting the international and domestic contexts to remind British officials to deal justly with locals and to accommodate their political aspirations. Such insights, of course, depend on liberating the narrative from the domestic and locating it in wider processes and trends. In that broader framework, there was a balance in that neither the power of the coloniser nor that of the colonised in shaping the constitutional process was overstated. Constitutional reform was the prerogative of the British in 1956 when they held the moral high ground on colonial matters. But Lim Yew Hock possessed the upper hand in 1957. By bringing both the international and domestic contexts into sharper focus, the narrative helps underscore not only Lim's agency in shaping the historical process, but also helps explain why constitutional progress advanced in 1957 and not in 1956 . The local politician's manoeuvres intersected in complex ways with the broader environment to affect constitutional reform in Singapore. By weaving all of these coexisting stories together, the historical narrative that is generated accentuates the limits of the power of the coloniser in dominating political change as well as the ingenuity of local politicians in harnessing metropolitan fears and anxieties to advance their political programmes.

\section{Transnational labour in Singapore}

Apart from Singapore's constitutional history, another area of study which can potentially be enriched if it is connected to wider contexts is the island's labour history. Recent writings (Harper 200I; Wee I999; Liew 2004; Liew 2006) have taken the 'social turn' and moved beyond 
traditional studies that focused on the ideological proclivities and politics of the labour movement (Drysdale I984: I75-6, I82-5; Lee I996). Examined and unpacked are the social aspirations of the workers and unionists and their everyday resistance and adaptation to social oppression and struggles. Still unstudied in great detail, however, is local labour's connection to international labour groups. By tracing and analyzing the Singaporean workers' movement's relations to these organisations and weaving both of these histories together, the dynamics and meaning of the labour experience in I950s Singapore can be better understood. One international labour organisation whose members were particularly active on the island was the International Confederation of Free Trade Unions (ICFTU). Indeed, to fully understand the intrigues and conflict between the pro-Labour Front government Singapore Trade Union Congress (STUC) and the combative unions that were established along Middle Road, one has to appreciate the role played by ICFTU officials in hardening the divisions in Singapore's labour movement. This section addresses that subject.

The ICFTU was an international labour organisation established in I949 to further the interests of non-communist unions worldwide. With the consent of the colonial authorities, it opened an office in Singapore in I95I and recruited the STUC as an affiliate. ${ }^{19}$ While the office consulted with local unions on collective bargaining and labour organisation during the initial years, its activities on the island intensified from the middle of I955, when it was called on to confront the so-called 'Middle Road' unions. The belligerent Middle Road leaders had initiated a series of strikes and labour unrest from March through June I955, crippling many industries and threatening to bring the whole of Singapore to a standstill. With about 35,000 of the I20,000 blue-collar labourers in Singapore under its sway, Middle Road's influence appeared to be on the upswing. ${ }^{2 \circ}$

These labour developments dismayed American Cold Warriors who thought the island was on the verge of union-led communist subversion. If Singapore fell, American policymakers feared that this would trigger a domino effect and lead to the collapse of other neighbouring states to communism. Such an outcome would be disastrous for US containment policy in Asia. American officials thus decided to act. In dealing with labour problems in Singapore, US policymakers believed the non-communist STUC should be strengthened and aided in the fight against Middle Road. The Americans also appealed to the ICFTU to help its Singaporean affiliate. ${ }^{21}$ Such a request to the ICFTU was, in fact, dispatched in October I955. ${ }^{22}$ Responding to the American entreaty and following a similar though uncoordinated plea by British officials, the ICFTU dispatched Dhyan Mungat, the ICFTU's Asian Regional Secretary, and Thomas Bavin, a specialist union organiser from the ICFTU and International Trade Secretariats of Land, and Food and Drink Workers, to 
Singapore. ${ }^{23}$ On their part, the Americans sent George Leon-Paul Weaver, an African American labour official, to help the ICFTU and STUC. To avert any misunderstandings that the effort to strengthen the STUC was an American undertaking, Weaver obtained the consent of the ICFTU to operate in Singapore as its official. ${ }^{24}$ Adhering to diplomatic protocol, permission was further sought and eventually obtained from the British for Weaver to work with the ICFTU on the island. ${ }^{25}$

In seeking to build up the STUC, the ICFTU representatives had their work cut out. The STUC suffered from weak leadership and lacked staff to advance its programmes. It also lacked funds and did not have a proper office. In contrast, Middle Road was led by dynamic and young organisers who had little difficulty finding supporters or keeping their cause well-financed. ${ }^{26}$ Additionally, although the two umbrella organisations differed in terms of their approaches to collective bargaining (the latter adopting a more antagonistic line), members of the two sides tended to gravitate towards each other, as both ultimately understood that they were fighting for the common cause of workers' rights. ${ }^{27}$ To prevent Middle Road and its leaders from dominating the STUC and the labour scene, therefore, the ICFTU had to ensure that its affiliate had the means and the will to prevail in Singapore. In fact, as will be seen, without the ICFTU's intervention, the STUC might have been absorbed into Middle Road.

In the event, work to enhance the STUC proceeded in earnest once Weaver joined the ICFTU officials in Singapore from June I956. First, Weaver was able to raise US\$5,000 from his parent organisation in the United States, the Congress of Industrial Organisations, to aid the STUC. The money was subsequently used to furnish the bare STUC office and to employ a number of new staff. Second, the ICFTU advisers attempted to increase the STUC's revenues by reforming the way union dues were collected. Instead of directing the unions to pay a fixed sum to the STUC annually, the ICFTU proposed to the STUC leadership that every union member should pay the institution M\$0.50 yearly. Unions with a large membership such as the I5,000-strong Army Civil Services Union, therefore, would generate more funds for the STUC than in the old system. Third, the ICFTU organisers helped the STUC to round up smaller-sized affiliates and merge them into larger bodies. They effectively reasoned with the unionists of the smaller entities that their bargaining power would grow if they combined forces. Fourth, they sought to strengthen the STUC's management. They helped to spot future leaders, and crafted organisation and negotiation programmes to train the next generation of STUC bosses. Fifth, they supported the STUC in collective bargaining. One such endeavour, which lasted from mid-I956 through early I957, involved the Ford Motor Factory. Weaver mobilised his contacts in the United Auto Workers (UAW), and, together 
with Bavin, engaged the Ford management in Singapore via a complex series of negotiations and strikes involving the Ford Motor Companies in Canada and the United States, the UAW, the US Department of State, the Malayan Trades Union Council, the ICFTU, and the STUC. Finally, the ICFTU representatives repeatedly fought off Middle Road's attempts to bring STUC members into its fold. Preaching labour solidarity and that strength lay in numbers, Middle Road's reconciliatory rhetoric had won over a number of STUC members. These unionists even attempted to rewrite STUC's constitution to permit an amalgamation of STUC and a key Middle Road group, the Singapore Factory and Shop Workers' Union. Bavin, however, intervened and dissuaded the STUC leaders from following through with the initiative. Weaver, meanwhile, used every opportunity given him to sow discord between Middle Road and STUC. When he was asked to speak at a gathering of Rotarians in August I956, for example, he tore into Middle Road's radicalism and told the meeting that employers would do better to negotiate with the STUC than trust Middle Road to honour any agreement. ${ }^{28}$

Overall, the outcome of the ICFTU's interventions was mixed, but ultimately instructive of the manner in which external actors influenced labour developments in Singapore. Although Weaver's initial injection of funds gave the STUC a new lease of life, the ICFTU could do little to resolve the longer-term financial health of the institution. By May I957, the 65,000-strong STUC was again short of funds as its affiliated union chiefs refused to adhere to the ICFTU's proposal to reform the subscription process. Lacking money, the STUC management thus laid off its recently employed staff, and sharply retrenched its services and programmes. Still, through its efforts, the ICFTU did manage to help the STUC persuade unions representing seamen as well as workers in the financial sector to combine forces and strengthen their bargaining power. On the STUC's behalf, Bavin's and Weaver's intervention at the Ford Motor Factory also turned out to be successful, with the employers eventually agreeing to improve the employees' working conditions and to give them a much-needed wage hike. And lastly, the ICFTU officials decisively ended talk of any merger between Middle Road and STUC, with their activities provoking Middle Road's hostility towards the STUC and ICFTU. This was one outcome the ICFTU worked hard to sustain and achieved it. ${ }^{29}$

What the discussion above shows is that labour's divisions during the I950s were not preordained or immutable. Certainly, there was local rivalry and antagonism among the different labour factions. Yet external elements with interests beyond Singapore's domestic concerns also intervened to harden the rift. Labour developments on the island thus became caught up not only in domestic issues, but also in Cold War politics. Historical analyses that focus only on the local would have missed those 
domestic-external links and been historically poorer for doing so. They would have further overlooked the state of play in local labour's struggles with multinational companies in Singapore, and their connections to international business and politics. The labour movement in Singapore was certainly not isolated from external solidarities that championed the same issues that it advocated locally: better working conditions, equitable pay, and social justice. Workers and unionists in Singapore had internationalist outlooks that went beyond the boundaries of the island, and they did not hesitate to look to these solidarities to push their cause if such external assistance was warranted or available. By locating Singapore's labour history in wider contexts and liberating it from the restrictions of the local, the complexity of its past is more accurately captured.

\section{Internationalising domestic politics}

While complex socio-political forces interacted and intersected in multifaceted ways to affect the labour movement in Singapore during the I950s, the island's domestic politics was also not shielded from international politics. Indeed, it was in the late-colonial and post-colonial world that much of the Cold War rivalry between the Soviet Union and the United States was played out. It was also in the so-called Third World that intra-alliance tensions brewed over questions related to imperial business and the manner in which the decolonisation process was advancing in the European empires. In Singapore, Britain faced challenges to its authority not only from local adversaries, but also from its allies, such as the United States. Although both shared similar strategic objectives in the Cold War and both were equally resolved to prevent late-colonial states such as Singapore from becoming subverted by communists, their methods for achieving those aims differed significantly. In fact, while the British readily cooperated in most instances with the Americans on the external defence of late-colonial states, London remained wary about permitting Washington to intervene directly in the empire's internal affairs (Louis I987). During the I950s, British officials had sent such a signal to American diplomats based in Singapore. Following the establishment of David Marshall's government in I955, the British had admonished the Americans and other foreign diplomats on the island to seek their agreement before engaging with local officials. The Americans, however, refused to comply, stealthily proceeding to meet with and cultivate the politicians as they saw fit. ${ }^{\circ}$

On their part, Singaporean officials were undoubtedly aware of the international and domestic environments in which they operated. Historians who overlook the broader context in which domestic politics developed during the I950s invariably miss the political games that the 
politicians played with external actors. Discussed in this section are Lim Yew Hock's and Chew Swee Kee's attempts to acquire foreign largesse for their party's (the Singapore Labour Front, and after I958, the Singapore People's Alliance) political activities. Their actions offer intriguing examples of how local politicians acted with inventive agendas and political guile to further their individual and party interests. Rather than onedimensional nationalists, anti-colonialists, or anti-communists, whose sole purpose was to rid Singapore of their adversaries and establish their political agendas on the island, the local personalities were also skilful political players who exploited the opportunities created by Cold War dynamics and the uncertainties of decolonisation to advance their personal and political ambitions.

Lim Yew Hock's strident anti-communism was particularly decisive in convincing US officials that he was worth supporting. The pro-Western and anticommunist image that he projected and attempted to sell to his potential foreign benefactor is testament to his astute appreciation of US political proclivities. In June I956, shortly after becoming Chief Minister, Lim had told an American diplomat that he was determined to lead Singapore "towards a positive anti-communist position" and that he hoped the United States would "help [him] from time to time." ${ }^{11}$ Apart from restoring order and seeking to win the confidence of the British, Lim's decisive measures against student and labour unrest in October I956 were also calculated to establish his anticommunist credentials with the Americans. He would succeed. Following the crackdown, US Secretary of State John Foster Dulles wrote the American consul-general in Singapore, requesting that he convey Washington's admiration of the Lim government's resolute stance against communism..$^{32}$ Under Lim, it seemed, late-colonial and post-colonial Singapore would not gravitate to the communist camp. That outcome, of course, hinged on his party staying in power. And for his party to stay in power, adequate finances were needed to fight elections. But as the Singapore Labour Front prepared to contest the I959 general election, which would usher in the commencement of full internal self-government in Singapore, Lim knew he needed to get his party's finances in order. He approached the US government for financial assistance.

In November I957, George Weaver, who had previously worked with Lim on labour matters in Singapore, carried a message from the chief minister to State Department officials in Washington. Weaver told the officers that Lim's party was in need of funds and that the chief minister might approach the US government for aid. Queried about the sum of money Lim needed, Weaver "indicated that Lim thinks he will need about \$I0०,000 (U.S.) to finance his political campaign.” He added, however, that from the American viewpoint, "any such assistance would be a calculated risk and would involve two important problems: I) how to handle 
the payments and 2) how to monitor Lim's disbursements." If those two issues could be appropriately addressed, however, Lim should be aided. ${ }^{33}$

US State Department officers subsequently resolved to aid Lim. They thought about Weaver's two stipulations, and eventually decided to approach British diplomats in Washington as well as British officers in Singapore to explore the possibility of funding Lim's party. The long and short of this story is that these efforts ultimately came to a dead end. The British governor in Singapore, William Goode, ruled the proposal politically hazardous and potentially counterproductive. With the governor emphatically opposed to any external attempts to fund the Singapore People's Alliance during the I959 general election, the State Department refrained from interfering overtly in the domestic politics of Singapore. ${ }^{34}$

Although Lim's effort to obtain financial support from the American diplomats fell through, his appeals for aid were taken seriously by another American institution. It is unclear how the American Central Intelligence Agency (CIA) got wind of Lim's predicament, but the covert agency decided to intervene. To resolve the difficulties Weaver raised about plausible deniability and American oversight of the use of the financial aid, the CIA communicated with a third party to handle the monetary transaction. Details of this third party - an ex-World War II psychological warfare expert turned businessman who was living in California - were furnished to the CIA by the Australian Secret Intelligence Service (Toohey I989). The CIA approached the businessman and obtained his pledge to assist the Lim government. Yet whether or not the third party did inject money into the Singapore Labour Front's campaign war chest remains a mystery. The available primary and secondary sources on the affair are silent on any financial transaction being made (Smith I976: 205-209 \& 236-238). Still, it is notable here that Lim's appeal had sent American officials from the CIA as well as the State Department scurrying to aid him. He was a shrewd politician who clearly knew how to exploit American insecurities about the Cold War for domestic political gain. Historical studies that depict Lim as a politically naïve and one-dimensional anticommunist Chief Minister need to be revised. The behaviour of politicians such as Lim are better understood when they are studied in the wider context of the Cold War, decolonisation, and domestic Singaporean politics.

While Lim Yew Hock managed to manoeuvre the Americans into locating campaign funds for him, Education Minister Chew Swee Kee was cultivating another potential patron. Although Britain had accorded formal recognition to the People's Republic of China, Chew had identified with Taiwan's anti-communism and was nurturing close relations with Taiwanese representatives in Singapore. It is uncertain whether he expected something in return, but his overtures to the Taiwanese would eventually 
bear fruit. When Chew set off on a tour of Japan and Hong Kong in September I957 to solicit campaign contributions for the Singapore Labour Front, the Taiwanese representatives in Singapore arranged for the education minister to meet with their foreign minister, George Yeh, in Hong Kong. At this meeting, Chew and Yeh talked about the political situation in Singapore. Yeh expressed his government's appreciation for the Lim administration's firm stance against communism while Chew reaffirmed his government's intent to continue to deal decisively with Chinese communist subversion in Singapore. More significantly, they discussed ways in which the Jiang Jieshi government could help the Lim administration fight communists on the island. ${ }^{35}$ Ostensibly, one of the ways in which Taiwan could assist the Lim Yew Hock government was by providing campaign funds, which Chew subsequently received in October 1957. And in April I958, there would be another infusion of money into the politician's personal account. ${ }^{36}$ Unhappily for Chew and the incumbent government, details of the transactions and how Chew had misappropriated some of the donated cash were leaked and published in the media on the eve of the I959 general election. Rival politicians swiftly took advantage of the exposé to verbally skewer the Singapore People's Alliance and its politicians for corruption. The Chew Swee Kee affair, in the end, dealt a fatal blow to the Singapore People's Alliance's hopes of carrying the election. Chew's political career came to a scandalous end in I959 (Ong I975: 69).

Despite the opprobrium the education minister brought on his party and himself, it must nevertheless be recognised that Chew's interactions with and success in obtaining Taiwanese support for the Singapore People's Alliance clearly reflect deft diplomacy. He evidently understood that Singapore was embedded in the security interests of another state, which believed that the stakes in Singapore were sufficiently high to warrant intervention against perceived communist subversion of the strategic island. Sino-Taiwanese rivalry and the Cold War had transformed Singapore's domestic politics into an international one with implications for the global balance of power. Equipped with that understanding, Chew could connect with his Taiwanese interlocutors and obtain the help that he thought was necessary for political success. For the electorate, however, his diplomatic skills did not excuse his lapses of character. Caught mishandling political donations for apparent personal gain, Chew would find himself and his party rejected by voters during the I959 general election.

The foregoing discussion shows how the Cold War, American and Taiwanese concerns about communism, and Singapore's domestic politics could intersect in intricate ways to engender profound historical outcomes in Singapore. The complex interaction and deals brokered among different personalities in different parts of the world would converge on the island and shape its politics during the I950 S. By bringing them together in the narrative, new information and new angles for 
understanding the lives, actions, and times of historical personalities such as Lim Yew Hock and Chew Swee Kee are illuminated. Like Lim, Chew is one among many multi-dimensional and enterprising personalities in Singapore's political history who should be reviewed and re-examined. For a start, they are more richly understood when they are located in wider concerns and contexts. Such renditions make these characters more complicated, to be sure. But the politicians also turn out to be more colourful and multifaceted than they have thus far been portrayed in the literature. Their lives, aspirations, and personalities, however flawed or honourable, convey a cosmopolitanism and internationalism that transcended the nationalist politics of their times.

\section{Conclusion}

With society in post-war Singapore marked by cosmopolitan sentiment and thought it is incumbent on historians to locate the history of Singapore in wider international and transnational frameworks. Contexts influence historical narratives, and broader contexts can shed new light on themes and subjects traditionally covered from a parochial national perspective. Singapore is clearly not an island to itself. Its history was bound up with world history and has been shaped by global historical events. And its history has also contributed to shaping global events such as the Cold War and the decolonisation of empires. The episodes discussed here merely offer a glimpse into the complexity of the developments in Singapore, and how they relate to Britain's retreat from empire and the Cold War. But they are indicative of the fruitfulness of locating Singapore in world history. The circumstances of the Cold War imposed demands on the British that cut into their dealings with Singaporean politicians who were eager to taste new constitutional freedoms, suggesting that the autonomy of local actors in pursuing more liberties from colonial rule can be exaggerated. Yet, by expanding the context in which constitutional change evolved during the I950s, the narrative presented here shows that local politicians such as Lim Yew Hock could also work the trends in international politics to their advantage. Such a manoeuvre would similarly be pursued by Lim and his party colleague, Chew Swee Kee, in their quests for campaign contributions from foreign actors for their political organisation. Finally, as social space opened up in Singapore with the progressive British retreat from empire, external actors, concerned about the security implications of the British withdrawal and its impact on the power balance in the Cold War, would rush in to press their claims on how these yawning spaces should be filled and shaped. To understand why and what the ICFTU and its supporters did in Singapore is to understand how they contributed to the labour movement on the island, 
ultimately missing a turn towards greater unity and consolidation during the I950s. By bringing the international and transnational back in, new ways of comprehending the social and political histories of Singapore can be examined. The decolonisation period and its intersection with the Cold War should prove fruitful for further research.

\section{Notes}

I For the Marshall outburst, see Singapore Legislative Assembly, Debates: Official Report, 6 June I956 (Singapore, I955). Scholars who have quoted the rant but not examined its connection to British cold war policy in much detail include (Bloodworth I986: I37-I38) and (Yeo \& Lau i991: 136).

2 The members included Australia, France, New Zealand, Pakistan, Philippines, Thailand, the United Kingdom, and the United States.

3 Eden Memorandum, I8 June I952, British Documents on the End of Empire, The Conservative Government and the End of Empire 1951-1957, Part I, International Relations, David Goldsworthy, ed. (London: HMSO, I994), 9-II; Churchill to Eisenhower, 7 January I953, Foreign Relations of the United States, 1952-1954, Vol. I2, East Asia and the Pacific (Washington, DC: Government Printing Office, I984), 256-257 (hereafter FRUS, with year and volume number); $42^{\text {nd }}$ Chiefs of Staff Committee (hereafter COSC) Meeting, Io April I954, FO 37I/II2053, the National Archives, Kew, London (hereafter TNA); and Churchill to Eisenhower, 2I June I954, FRUS, 1952-1954, 6: I069-I070.

4 The quotation is from MacGillivray to Martin, I2 July I956, FO Io9I/97, TNA.

5 Commonwealth Relations Office to UK High Commissioner (Australia and New Zealand), 30 November I955, DEFE 7/II54, TNA.

6 Loewen to Templer, 2I October I955, WO 216/902, TNA.

7 “Defence Agreement," annex to BDCCFE Memorandum, 27 October I955, FO Io9I/7, TNA.

8 "Defence Requirements," appendix to COSC Note, 3 November I955, DEFE 5/62, TNA.

9 "Importance of Singapore," annex to Wykeham to COSC, 24 March I956, DEFE 7/503, TNA.

Io "Speech," attached to Black to Martin, 5 April I956, CO I030/I20, TNA.

II Martin to Allen, I4 April I956, CO I030/ı20, TNA.

I2 "Attack on S.E.A.T.O. by Mr. Marshall," Times, 7 June I956.

I3 Durbrow to U.S. Department of State (hereafter DOS), I5 December I956, Record Group 59 (hereafter RG 59), 746F.o0 (W)/I2-I456, National Archives, College Park, Maryland, USA (hereafter NACP).

I4 "Singapore Constitutional Development," attached to Melville to Powell, 27 November I956, DEFE II/I86, TNA. For the August exchange, see "Singapore Constitution," 24 August I956, attached to Martin to Powell, 30 August I956, DEFE 7/504, TNA.

I5 "Brief - Informal Discussions," 22 August I956, DEFE 7/504, TNA.

I6 For the military's viewpoints, see Powell Minute, 20 August I956, DEFE 7/504, TNA; and BDCCFE Note, 22 November 1956, attached to Secretary (BDCCFE) to Secretary (COSC), 23 November I956, DEFE II/I86, TNA. For the Colonial Office's opinion, see "Singapore Constitution," 24 August 1956, attached to Martin to Powell, 30 August I956, DEFE 7/504, TNA.

I7 UK Defence Minister Brief, I7 January I957, DEFE 7/504, TNA.

I8 “Singapore Constitutional Conference Report," II April I957, attached to Odgers Memorandum, Io April I957, DEFE 7/504, TNA. 
I9 Mungat Memoranda, 4 and 28 February I95I, ICFTU Papers, Folder I236, International Institute of Social History, Amsterdam, the Netherlands (hereafter IISH).

20 Anderson to DOS, I9 August I955, RG 59, 746F.00/8-1955, NACP.

2I Wisner to Rockefeller, I June I955, FRUS, 1955-1957, 22: 736; Kocher to DOS, I4 October I955, RG 59, 746F.00/IO-I455, NACP; and Weaver, "Report," October I955, attachment to Sullivan to Young, I9 October I955, RG 59, 846F.062/I0-I955, NACP.

22 "Report on the Singapore Labor Movement," undated, attachment to Weaver to Oldenbroek, 27 October I955, ICFTU Papers, Folder 3772, IISH.

23 See Bulpitt to Braine, 2 September I955, LAB I3/II2I, TNA; Morris to Mackintosh and Bourdillon, I6 November I955, CO I030/367, TNA. See also, Mackintosh to Black, I7 November 1955, CO 1030/367, TNA.

24 Lippe to DOS, 28 June I956, RG 59, 846F.062/6-2856, NACP.

25 Durbrow to DOS, 23 December I955, RG 59, 846F.062/I2-2355, NACP; and Feld to Dulles, 3 March I956, RG 59, 846F.062/3-356, NACP.

26 Weaver, "Report," October I955, attachment to Sullivan to Young, I9 October I955, RG 59, 846F.062/10-I955, NACP.

27 For the tendency, see Lippe to DOS, 8 March I956, RG 59, 846F.062/3-856, NACP; and White to DOS, I4 September I956, RG 59, 846F.06/9-I456, NACP.

28 White to DOS, I4 September I956, RG 59, 846F.o6/9-1456, NACP; and Lippe to DOS, 28 June I956, RG 59, 846F.062/6-2856, NACP; Weaver, "Report on the Singapore Trade Union Congress," I9 July 1956, Weaver Papers, Box 3, Folder 26, Walter P. Reuther Library, Detroit, Michigan, USA.

29 White to DOS, I4 September I956, RG 59, 846F.o6/9-I456, NACP; Cottrell to Dulles, 28 January I957, RG 59, 846F.062/I-2857, NACP; Lippe to DOS, 8 March I957, RG 59, 846F.06/3-857, NACP; and Lippe to DOS, 24 May I957, RG 59, 846F.o6/5-2457, NACP.

30 Durbrow to DOS, 22 October I956, RG 59, 746F.00/10-2256.

3I Memorandum of Conversation, Io June I956, in Anderson to DOS, I2 June I956, RG 59, 746F.00/6-1256, NACP.

32 Dulles to Durbrow, 29 October I956, RG 59, 746F.00/10-2956.

33 Memorandum of Conversation, I3 November I957, Lot File 63 D I8, Box 22, Folder: I957 350.3 Lim Yew Hock, RG 59, NACP.

34 Memorandum of Conversation, 24 April 1959, attachment to Peterson to Herter, 25 April I959, 746F.00/4-2559, RG 59, NACP.

35 Holdridge to DOS, 5 November 1957, 746F.00/II-557, RG 59, NACP.

36 For the Taiwanese link to the money, see The Straits Times, 8 April I959; 9 April I959, and II April 1959; and Central Intelligence Bulletin, 2I March I959, CIA Records Search Tool (CREST), NACP. 



\title{
12 The Global and the Regional in Lee Kuan Yew's Strategic Thought: The Early Cold War Years'
}

\author{
Ang Cheng Guan
}

\begin{abstract}
"You can always survive a mistake in domestic affairs but you can get killed by one made in foreign policy" (Freeman I997: 154)

"The foreign policy of Singapore must ensure, regardless of the nature of the government it has from time to time that this migrant community that brought in life, vitality, enterprise from many parts of the world should always find an oasis here whatever happens in the surrounding environment"
\end{abstract}

\section{Introduction}

In studying Lee's strategic thought, it is imperative to ask: what do I mean by 'strategic thought'? The term 'strategy' means different things to different scholars. In the words of a strategic studies scholar, Bernard Loo, "at the end of the day, however, it seems to me that these notions of strategy really focus on the traditional definitions of security - the absence of external threats to states, in terms of both sovereignty as well as territorial integrity. In that regard, conceptions of geopolitics and how it translates into foreign policy exist quite comfortably within the rubric of security; and strategy (however defined) can be thought of as the logic that underpins the ways in which the use of instruments of power and force (both military as well as non-military) helps to ensure this 'security." "This article is therefore about Lee Kuan Yew's philosophy on foreign policy, his thinking on geopolitics as well as war and peace, all the while bearing in mind Raymond Aron's dictum that strategic thought "draws its inspiration each century, or rather at each moment in history, from the problems which events pose" (Buchan I970).

Lee's strategic thought was essentially shaped by Singapore's unique situation as a small island state without a hinterland located in a strategic yet vulnerable region. It was formed against the backdrop of the worsening Cold War between the anti-communist West and the expanding communist bloc, which stretched across the Eurasian mainland to China, with the nations of the nascent non-aligned movement caught somewhere in 
between. As Lee reminded his audience in his S. Rajaratnam Lecture in 2009, "small countries have little power to alter the region, let alone the world." The strategic challenge Lee faced from the very beginning was how to ensure "Singapore's survival and prosperity as a sovereign and independent nation" (Lee Kuan Yew 2009: 5).

While much has been written about Lee and his leadership role in the development of Singapore, almost all studies have focused on his domestic policies and on issues of governance with hardly any reference to his foreign policy thinking. None of the reviews of Lee's memoirs, The Singapore Story have much to say about his foreign policy. This is somewhat surprising considering the fact that Lee is generally acknowledged as Asia's leading strategic thinker", one who does not flatter but "who is known, from time to time, to speak bluntly" , and someone who helps "us find direction in a complicated world." ${ }^{6}$ There is therefore a gap in the literature waiting to be filled and ample space for a historian's treatment of this subject.

This article is part of a much larger research project which attempts to document and contextualise the change and continuity of Lee's strategic thinking and its evolution from the I950s when he first embarked on a political career, to the present. With reference to timeframes, Lee's tenure as Prime Minister coincided with the period of the Cold War. His tenure as Senior Minister (a title that he assumed after stepping down as Prime Minister in November I990) and Minister Mentor (since August 2004) fell rather neatly into the post-Cold War period. This article however covers only the period from the I950s to I975 - the end of the Vietnam War and before the start of what is commonly known as the Second Cold War. As Lee noted, the fundamentals of Singapore's foreign policy were forged during those "vulnerable early years" (Lee Kuan Yew 2009: 5).

With regard to sources, the documents of the Foreign and Defence Ministries (MFA and Mindef) as well as the Prime Minister's Office (PMO) remain closed (indefinitely). Without access to the primary documents, Lee's two-volume memoir is possibly the next best source and a logical starting point for any research on Lee's thoughts and actions. The memoirs, we are told, had drawn on "unpublished Cabinet papers, archives in Singapore, Britain, Australia, New Zealand and the United States, as well as personal correspondence" (Lee I998 \& 2000). Accurate though they may be, memoirs cannot substitute for and can at best only supplement the documents of the period under study. For this paper, I am focusing my attention exclusively on the transcripts of Lee Kuan Yew's speeches, talks and interviews pertaining to international politics from the I950s to I975. This choice of source merits some elaboration. Lee delivered many speeches, gave numerous talks and interviews on the major international geopolitical issues of the day. These are easily accessible?, but have surprisingly not been tapped into by scholars. One possible reason is that 
historians these days consider records of what politicians said publicly as inferior to archival documents. Paul Readman reminded us that historians had always made use of speeches - from the Greek and Roman historians to the historians of the nineteenth century (Dobson \& Zieman 2009). This paper systematically examines Lee's public statements on international politics over the years - a valuable but underrated source (Dobson \& Zieman 2009). Interestingly, Lee Kuan Yew indirectly gave some advice on how to interpret his political speeches and related statements. In his speeches, talks and interviews, Lee said he needed to strike a balance between (a) "maintaining confidence and stability" with "the need to alert people" and (b) being polite and also truthful ("I have to be polite but also don't want to be untruthful"). ${ }^{8}$ Historians seeking to make use of Lee's public statements to understand his thinking should bear this in mind.

\section{On the nature of international politics (the 1950s to August 1965)}

Singapore achieved internal self-government in 1959, but foreign policy and defence remained under the purview of Whitehall until I963 $_{3}$ when Singapore merged with the Federation of Malaya to form Malaysia. From I963 till Singapore's independence in August 1965, foreign policy and defence was controlled from Kuala Lumpur and not by Prime Minister Lee Kuan Yew. There is relatively little information on Lee's views on international politics and foreign affairs before August I965 compared to the period after. However, it is possible to get insightful glimpses into his strategic thought in the earlier period. For instance, he did make the point that foreign or external affairs was "a matter of life and death" and that it was "an extension of domestic affairs" - "what we say and what we do in the field of foreign politics is so often the external manifestation of our domestic politics, our internal hopes and fears that the embassies that we established... reflected the affinity and identification of political attitudes and political premises." 9 In a speech to the International Institute of International Affairs (Australia), which is perhaps his most substantial discourse on this subject pre-August 1965, he said that international affairs was as old as man. "From the first tribes to the modern nations, man may have learned how to use wood and stone and metal and gunpowder, and now nuclear power. But the essential quality of man had never altered. You can read the Peloponnesian wars, you can read the Three Kingdoms of the Chinese classics, and there's nothing new which a human situation can devise. The motivations for human behaviour have always been there. The manifestations of the motivations whether they are greed, envy, ambition, greatness, generosity, charity, inevitably ends in a conflict of power position. And how that conflict is resolved depends upon the accident of the individual in charge of a particular 
tribe or nation at a given time. But what has changed is the facility with which men can now communicate and transport not only ideas but also man himself and his weapons. Therefore, in a very old situation has been introduced a very alarming possibility which puts the whole problem of international relations now in a very different perspective." tribe in proximity with another tribe is happy until a state of dominance of one over the other is established. Or until it has tried to establish that dominance, and failed, and it is quite satisfied that it is not possible, whereupon it lives in fear that the other tribe will try to assert dominance over it. And the cavalcade of man will go on..." II

He was to reiterate this point in another speech in 1967 , when he noted that developing countries like Singapore which had no "power" would need to "arrange their relationship with the developed countries in order to exercise some influence" in one of two ways: (a) pursue appropriate policies/strategies to tap power and/or (b) coming together to increase their capacity to influence events. ${ }^{12}$ There was thus much that one can learn from the study of history. He did not believe history was bunk, for it "has some relevance to tell us something about the natures of people and their cultures and their societies" ${ }^{13}$ and "it should teach us, if we can learn from experience at all, what should be avoided and what more can be done for a better tomorrow." ${ }^{14}$

His education might also have shaped his early ideas on this subject. An address he delivered in 1967 when he received an honorary doctorate of Law from the Royal University at Phnom Penh, Cambodia, sheds some light on this. In his speech, he recalled being taught international law by the late Sir Hersch Lauterpacht, Whewell Professor of International Law, in Cambridge, who later became a member of the International Court of Justice at The Hague. What stuck in his mind was the difference between municipal and international law: "The law of each individual country is binding on all its subjects except the sovereign. The law of the international community has one missing element: enforceable authority. In legal theory, every government of every independent nation is sovereign and supreme." As a young lawyer, Lee assisted in defending the members of the University Socialist Club (USC)/Fajar editorial board who were charged with sedition for publishing an article entitled "Aggression in Asia," which condemned the formation of the Southeast Asia Treaty Organisation (SEATO) (Yap, Lim \& Leong 2009: 34-35). Lee was personally critical of SEATO. "SEATO is nonsense," he said. ${ }^{15}$ When asked whether SEATO was an adequate framework for Southeast Asian security, Lee noted that SEATO was inferior to NATO, “... And until you convince Asia that you consider Asia as important to you, as Americans, as Europe is to America, you are going to find lots of Asians like me rather critical and really doubting because ninety per cent of you have come from Europe; you understand Europe better than you understand Asia." ${ }^{16}$ 
Two events in I956 further shed light on Lee's thinking of international relations: the Anglo-French-Israeli invasion of Egypt (also known as the Suez Crisis) and the Soviet invasion of Hungary. With regard to the former, Lee approved of the US response to the Anglo-French-Israeli invasion of Egypt, which "shocked and angered the whole non-European world" and was "a reminder of the perfidy and ruthlessness of the gunboat policy of the imperialist powers of a bygone age." According to Lee, "fortunately, for the peace of the world, the Americans refused to support Britain and France, but instead joined the rest of the world in condemning the blatant act of aggression... The Egyptian blocking of the Canal symbolised the end of the gunboat age for Britain and France." As for the invasion of Hungary, which he described as "bloody and brutal armed suppression of Hungarian patriots," Lee noted that "history may well mark this event as the turning point of Soviet Communism in the West and perhaps in the whole world. Never before has any single event in the Communist world split the Communist parties of Europe as Russia's cruel action in Hungary has done..." ${ }^{\text {17 }}$

In a talk he gave in I959, Lee observed that since the end of the Second World War, "the political face of Asia has undergone more change than during any other equivalent period in Asian history. Events have taken place which are likely in the next few decades to shift the centre of gravity from Europe and the West to Asia and the East." He believed that "the massive potential greatness of India and China" would dominate the Asian scene" and "what happens to the rest of Asia" was bound to affect Malaya, including Singapore. In one of his earliest analyses of the development of the Cold War in Southeast Asia, Lee was of the view that if there were a free-for-all in Malaya, a movement of the Chinese urban proletariat might assume power and dictate the course of the revolution. But this was impossible, as the British and the Americans "would never allow a free-for-all in Malaya." If Communist China and the Soviet Union were prepared to intervene, as in Indo-China, and throw their weight on the communist side, then the position would be different and a small militant party might succeed in capturing power. But they are not "and will never be so stupid as to intervene." Beijing wanted to win over 80 million Indonesians, and many more millions of the uncommitted people in Southeast Asia. "And nothing is more likely to make the Southeast Asian countries more anti-communist than the spectacle of China coming to the aid of Chinese minorities in Southeast Asia."

Thus Lee believed that "the immediate danger to Malaya is not Communism but Communalism... There can be no Communist Malaya until there is a Malay-led Malayan Communist Party," because it was the Malay peasantry and not the Chinese urban proletariat who determined the pace. And there was no likelihood of any significant Malay-educated elite becoming disgruntled in the foreseeable future. In the meantime, the 
communal tensions could easily increase. In his words, "there are bound to be groups who are prepared to exploit the dissatisfaction of the urban Chinese by making communal appeals. On the other hand, the Malay sector is equally opened to exploitation by communal and, this is more serious, by religious appeals..." Answering the question as to whether the existence of a left-wing government elected by a largely urban Chinese population in Singapore would aggravate or alleviate the situation, he suggested that the answer depended upon how the Government in Singapore conducted its affairs, whether it pandered to Chinese chauvinism..." For there is no possible way of ensuring that the Singapore situation can be isolated from the Federation." ${ }^{8}$

\section{On the non-aligned movement}

One of the most important and influential segments of the international community in the post-World War Two years was the newly independent Afro-Asian bloc of countries (or non-aligned nations), which comprised about a third of the world's population. Lee explained: "They used to be called neutralists since it was believed that in a war they could remain neutral. But the age of the jet and the hydrogen bomb makes a mockery of any hope that anyone can escape the consequences of world conflict. And so, they began to be called non-aligned instead of neutralist. They do not line up with either the East or the West, either the Communists or the anti-Communists on any issue. But they take a stand on every issue that affects them. But unlike the countries within the two blocs, they decide, not according to the stand of either America or Russia, but according to the interests of their people, the under-developed peoples of the world." Lee believed in the idea of non-alignment, but with a caveat: "We are nonaligned if we are asked to choose between competing power blocs. We are non-aligned if we are asked to choose between the interests of competing ideologies of Communism or Capitalism. But, we are not non-aligned, nor can we afford to be neutral, when our own existence, our happiness, and our future are at stake." He recalled how at the time of the Soviet blockade of Berlin (I948), he did not understand how that conflict had anything to do with him, as he was non-aligned. "Today, I understand that had the fight been lost, I would not perhaps have emerged in Southeast Asia." ${ }^{20}$

One of his top priorities was getting Singapore's independence recognised by the Afro-Asian nations. In his press conference on 26 August i965, Lee revealed that it took almost two weeks before Egypt's President Nasser decided to accord recognition. The African countries in particular, Lee revealed, had their reservations because of the British bases in Singapore. Lee and his colleagues had to convince them that he 
was not a "neo-colonialist stooge" and eventually all, except Indonesia, recognised Singapore's independence. ${ }^{2 \mathrm{I}}$ Indonesia's influence was considerable. According to Lee, had Indonesia been willing to welcome Singapore into the ranks of the Afro-Asian nations, "it would have helped so much to settle our problems of legitimacy as an Afro-Asian nation." But as Indonesia was not forthcoming, Singapore had to "do it the hard way: convince all Afro-Asian nations, almost one by one in the United Nations and at Afro-Asian gatherings..." ${ }^{22}$ Soon after independence on 9 August 1965, the then-Deputy Prime Minister Toh Chin Chye and Foreign Minister S Rajaratnam visited the Afro-Asian countries in September and October 1965. As Lee explained, “... we must maintain good relations with the Afro-Asian countries economically, culturally and in the matter of trade." 23

Even so, Lee did not see the Afro-Asian bloc through rose-tinted glasses. As he told his Canterbury University (Christchurch, New Zealand) audience, "the first bloom of Afro-Asian solidarity against Western domination in the period between ' 45 and ' 55 , the high-water mark of which the Bandung Conference [I955] when Pantjasila and solidarity of all former subject peoples in themselves believe in a new code of Afro-Asian ethics in peace, non-interference, non-aggression, mutual respect and regardless of size and power, mutual help. Well, that phase has gone..." ${ }^{24}$ Lee compared Southeast Asia with South Asia, which was in a period of malaise because the South Asians, who actually had much in common, were quarrelling amongst themselves. He reiterated his concern in the wake of Confrontation that Southeast Asia could be Balkanised, which would play into the hands of the communists. He argued that the communists had a vested interest in the instability of the region, because instability generated economic and social discontent, which in turn undermined confidence in the incumbent regimes and their ability to produce solutions, thus creating the very situation the communists need to succeed. ${ }^{25}$

\section{On the nature of international politics (post-August 1965)}

Singapore became independent on 9 August 1965. Lee Kuan Yew was now fully responsible for Singapore's foreign relations and defence. As he told his audience on 26 September 1965, "we have, on the one hand, to look after the international relations for our country, and on the other, we have to look after the livelihood of our people." ${ }^{26}$ In subsequent speeches and interviews, he spelt out the rationale and principles of Singapore's foreign policy: "We are now the arbiters of our foreign and defence policies, and our strategic importance makes our foreign and defence policies a matter of interest not just to our immediate 
neighbours but to a larger group of nations whose ideological and power conflicts have gripped the world in a cold war since the end of the Second World War... Singapore, first must decide where its long-term interests lie. And, within that context, a foreign policy must be designed to bring us the surest guarantee of our survival and our prosperity." ${ }^{27}$ Between pre and post-independence there was a world of difference. "This time we are playing for keeps and if we make a mistake there is no safety net underneath..." To Lee, Singapore's survival is not negotiable. "This is something fundamental. We may be small but we are sovereign in (?) how we ensure our own survival." ${ }^{8}$ In a speech entitled, "Changing Values in a Changing World," he noted that economics and politics were closely inter-related and that there was a "sinking realisation" that "good economics must be the basis of good politics." ${ }^{29}$ According to Lee (and he reiterated this premise on several occasions), "trade and industry is as important to us as defence and security," $3{ }^{\circ}$ and "defence and security is indivisible from trade and industry." ${ }^{31}$ The promotion of trade was thus a key objective of Singapore's security (foreign and defence) policy. "I am nobody's stooge. I am not here to play somebody else's game. I have a few million people's lives to account for. And Singapore will survive, will trade with the whole world and will remain non-communist," he declared. ${ }^{32} \mathrm{He}$ exhorted the leadership in the business community to pay more attention to international politics. "The idea of a man being interested only in business - not interested in what is politics; not interested in relations with other countries; interested only in business - in profits... I do not say that that attitude was wrong, but it is inadequate in this new situation..." ${ }^{33}$ Lee understood the concept of security very broadly. "There are other aspects of security which are equally pertinent in the long run (not just physical security): your economic viability, the capacity of your political structure to withstand pressures either of a social, cultural or whatever nature. It is a multi-coloured question." 34

In a I966 speech entitled "International Relations"35, Lee gave a lesson on the subject of 'foreign policy' when he highlighted "two things which we must always keep clearly in mind" whenever we talk about the foreign policy of a particular country. These were: (a) the foreign policy which is designed primarily for the long-term national interests of a group of people organised into a nation; (b) the foreign policy which is designed for the specific and special interests of the type of regime or the type of political leadership that is for the time being in charge of the destiny of that country. To confuse the two would lead to "grave misjudgements as to what are likely to be the power situations in various parts of the world from time to time." He gave the example of Indonesia. There were, according to Lee, "certain aspects of policy which any Indonesian Government must pursue regardless of its particular ideological or political flavor. You can change governments but there are basic compulsions of 
a people grouped together as to the things they want to do. But when you change governments, there are certain objectives which a previous regime pursued which are abandoned as unprofitable."

Lee further identified two factors which must always be borne in mind when talking about the foreign policy of Singapore: (a) The juxtaposition of power interests in a particular region (which he considered as, if not more crucial than geography in determining Singapore's strategic importance); (b) the effect of human migration over time and space. Bearing in mind these two factors, Singapore's foreign policy must firstly "ensure, regardless of the nature of the government it has from time to time, that this migrant community that brought in life, vitality, enterprise from many parts of the world should always find an oasis here whatever happens in the surrounding environment." Thus a foreign policy for Singapore must be one as to encourage the major powers to find it, if not in their interests to help us, at least in their interests to not have us fail. And secondly, it, "must always offer to the rest of the world a continuing interest in the type of society we project."

Finally, Lee placed considerable emphasis on 'power'. He said that any foreign policy must achieve two objectives: the right political climate and power. "For you can have the best of political climates, but if the power to sustain your position is not there, then you must lose."

\section{On Singapore-Malaysia-Indonesia relations post-August 1965}

With regard to Singapore's relations with Indonesia and the Federation of Malaya, which "geography ordains that we shall always be neighbours" 36 , Lee had this to say, which is as true today as in 1959: "There is no doubt that with better relations with our neighbours, like Indonesia our trade may still increase. But we would be blind if we did not recognise the tremendous change in the pattern of trade and commerce in Southeast Asia. Both our two closest neighbours - the Federation of Malaya and Indonesia - have, not unnaturally, since they attained their independence, set themselves out to build their own industries. They want to establish their own trade lines with foreign countries without having to go through the merchants and brokers in Singapore." ${ }^{37}$ With regard to Malaysia, as Foreign Minister S Rajaratnam said, "there is something unreal and odd about lumping our relations with Malaysia under foreign relations. But then some rather odd things do happen in the history of peoples and countries. ${ }^{18}$ But that was the reality of separation. In the wake of separation, Lee said that "we do not believe that ties of kinship, history and geography can be broken or destroyed just by one constitutional amendment," 39 and "interdependence makes it inevitable, that maybe in ten years, maybe less, maybe more, (and) it must come back together again, perhaps under 
somewhat different conditions and circumstances. But I have not the slightest doubt that that must be so," a point he reiterated a year later: "I don't see these boundaries as being immutable." ${ }^{\circ 0}$ Lee made a distinction between 'peoples' and 'governments'. "Friction between governments," he said, "may come and go, (and) may change with time."

The 'interdependence' theme was reiterated in his speech during the first session of parliament in December 1965, when he said "... But I think we would be dishonest to ourselves if we did not express a profound interest in the policies and the consequences of such policies upon the relationship between the communities in Malaysia which would, in turn, help to influence attitudes and relationships between communities in Singapore. I see the future more fraught with danger than before separation - the long-term future. For, if there is a failure to understand this nexus between us, then it is extremely easy for one to embrace and to influence attitudes and policies in the other which, as I have said, must end in the polarisation of two opposing attitudes based on two opposing assumptions of superiority of race, language, and culture, which can only spell disaster for all." ${ }^{42}$ That there were deep-seated differences between Singapore and Malaysia is obvious. Otherwise, it would not be necessary to take such a drastic step as separation. Three and a quarter years after separation, Lee did not think the differences had been resolved, but acknowledged that both sides had moved some way to accepting the difference, although there were "compelling almost irresistible pressures on cooperation." But the reality was that "the unity of the two in the security interest of both cannot be willed or wished away and we just have to learn to cooperate in a very quiet and commonsensical way or we both perish." 43

As for Indonesia, Lee made two points: Singapore would like to have "good and friendly" relations with Indonesia on the condition that neither side interfered in the internal affairs of the other. Although what happened within Indonesia is a matter "entirely for the Indonesian people" to decide, developments in the country "have the gravest consequences for all of us who live in the region..." 44 With regard to Confrontation and Indonesian Foreign Minister Subandrio's proposal that there should be bilateral negotiations with Singapore, Malaya and the Borneo states separately, Lee's response was that he was prepared "to talk to anybody, at any place, at any time, to achieve peace and security for Singapore." 45 It did not matter if Malaysia objected to the proposal. "We want to be friends with Malaysia, but that does not mean that we have to be unfriendly with all the people who are unfriendly to Malaysia. Their friends may be our friends... but Malaysia's enemies need not be our enemies..." 46 The old aphorism, 'Where you stand is where you sit' is most true as Lee revealed that if Singapore were still happily part of Malaysia, he would have rejected Subandrio's offer: "We would be outraged at the provocativeness of it. But, we are out of Malaysia and we have got to look at our 
little sector." 47 That said, Lee also pointed out that it would be unwise, short-sighted and opportunistic for Singapore to improve relations with Indonesia at the expense of Malaysia. "Singapore wanted rapport with Malaysia, regardless of our position with Indonesia; and we want rapport with Indonesia regardless of our position with Malaysia." All said, "We must never forget our abiding destiny as part of the continent of Asia." ${ }^{8}$ In his first Parliament speech, Lee expanded on this point: "We are here in Southeast Asia for better or for worse and we are here to stay, our policies are designed to ensure we stay peacefully in Southeast Asia in accord and amity with our neighbours but with a right to decide how we order our own lives in our own home. And every action, every policy must be decided by this yardstick. Any policy which endangers our longterm interests as a separate and distinct community in this region must be eschewed; and any act, any programme, and decision which will help us secure a more enduring future for ourselves and our progeny in this region must be pursued whatever the sacrifice." 49

In general, Lee felt that in foreign relations, "your best friends are never your immediate neighbor," a point he reiterated on a number of occasions. "Your neighbours are not your best friend, wherever you are," Lee declared in a speech on the subject of 'International Relations.' This is because "it gets too close and your neighbour's hedge grows and infringes on your part of the garden and the branch of his fruit tree covers your grass and your roses do not get enough sunshine and so many things happen. And therefore our best friends, as has happened with so many other countries, are those who are farther afield with whom we can talk objectively." $5^{\circ}$ Thus, he felt that with Malaysia, both sides should forget about sentiments and just do business with each other because "if we go into sentiments, emotions, feeling, there is going to be a great deal of antipathy... you can go into real orgies of bitterness and hate." ${ }^{\prime r}$

As for Indonesia, the abortive coup that took place there on 30 September/I October 1965, also known as the Gestapu affair, was the beginning of the end of Confrontation. Towards the end of 1965 , there were rumours about the construction of a new cooperation framework, taking into account the new regional architecture. There was already ASA (Association of Southeast Asia), which was formed in I96I - comprising Thailand, then-Malaya and the Philippines - which foundered because of the rift between Malaysia and the Philippines over Sabah and was further complicated by Confrontation, which questioned the legitimacy of Malaysia. ASA was subsequently replaced by ASEAN in August 1967. In early I966, when asked whether Singapore would consider joining ASA, Lee said that Singapore was "extremely interested in regional cooperation," be it "bilateral or multilateral" for economic, cultural and social purposes. But he would want to know first the purpose of the organisation and the benefits for member-countries. Lee believed 
that the idea of each small country being independent economically ("economic autarky") was "old fashioned and deleterious in its effect." ${ }^{2}$ But he opposed MAPHILINDO, which he felt was exclusively Malay and Islamic and thus did not offer a sufficiently broad spectrum for Southeast Asian cooperation..$^{33}$ Any proposal that focused on regional cooperation for mutual benefit was good, but such proposals must also be "political acceptable," meaning that they should be presented "in a more realistic way by a more representative cross-section of Southeast Asian countries" and that "the objectives are clearly defined as not part of the Cold War conflict." ${ }^{54}$ He believed that, in the long term, joining or forming a regional association or group was "the only way in which the smaller and not very viable countries in Southeast Asia can sustain their separate existence in a world dominated by two or three superpowers." ${ }^{55}$

In the early years of Singapore's independence, given the poor relationship with both Malaysia and Indonesia, it was not surprising that there were concerns, valid or not, that Singapore might be threatened if not swallowed up by one or the other, or both. In response to a question that Singapore was a "nut" and that Malaysia and Indonesia together were a "joined-up nutcracker," Lee recalled reading an account of a conversation between Stalin and Tito in Milovan Djilas's book, Conversations with Stalin. Stalin said to Tito: "Why not swallow Albania?" But the shrewd Tito did not do that because, according to Djilas, if Yugoslavia had done that, it might not be there today. He provided a fish allegory. "The big fish says to the medium-sized fish, "Why not swallow up the small one?" And the medium-sized fish if it is sufficiently unthinking goes and does it. Then, the big fish will eat not only the medium one but he will also have the smaller one! And I think that would be a more satisfactory meal all around because both will be eaten up in one gulp. ${ }^{.56} \mathrm{It}$ is a no-brainer who the small, medium and big fish are Lee was referring to.

This was later expanded into one of Lee's most memorable speeches on the nature of international relations entitled, "Big and Small Fishes in Asian Waters. ${ }^{57}$ A number of points in this wide-ranging speech are worth highlighting: Lee spoke of the United Nations, in which in form and formality, all countries in the world, big or small are all independent, sovereign nations with equal voting rights. From that perspective, "we are all equal: we all pretend that we are equal. But we are all acutely conscious of the fact that we are not equal." Referring to the five permanent members of the Security Council, "if the five big fish in the world decide that this should be so, then it must be so." But the assumption was that the five would always remain big, and there was no provision for adjustment. Drawing on history, Lee noted that "the belief that dictating a peace treaty with unconditional surrender on the Germans and almost unconditional surrender on the Japanese would be able to determine things for all time is just not true." 


\section{On the major powers and Southeast Asia}

Lee, however, did not think that the future of Southeast Asia could be decided by Southeast Asians alone. The major powers (specifically, US, China and Soviet Union) would in varying degrees continue to maintain "a profound interest in the region" because of the region's sizeable population, minerals and other natural resources, and it housing one of the most important sea junctions in the world. None of the three powers, in Lee's view, really understood the peoples of Southeast Asia..$^{58}$ With regard to the Soviet Union, he saw Soviet naval expansion into Southeast Asian waters as a natural extension of their power and influence, which would not pose a threat "unless they are the only naval power in the area." If there were several powerful fleets, they could all play a balancing role. 59 But he did not think there would be a sizeable Chinese naval presence in the region for some time. ${ }^{60}$

Turning to China, Beijing openly supported Indonesia's confrontation against Malaysia. In March I965, Lee Kuan Yew offered one of his most substantial analyses about China vis-à-vis Southeast Asia to date. In response to the question as to whether the increase in power and influence of communist China worried him, Lee said yes if it led to the "miscalculations on the side of the Americans as to how far the Chinese would go in backing revolution in Southeast Asia"; and no because he did not believe that the Chinese "if you read their history - that they would want to conquer, physically South and Southeast Asia. They are very big, selfpossessed, completely self-confident people with enormous patience." With their Middle Kingdom mentality, the Chinese just wanted a continuation of the tributary system. The problem, accordingly to Lee, was not so much "Chinese aggression" (meaning: Chinese armed soldiers marching down Southeast Asia). If that were to happen, "the problem would be much simpler," because Communism would be equated to Chinese imperialism and the rest of Asia would certainly cooperate to fight it. Lee noted that the Chinese were "much more subtle... They believe in revolution. They are going to help revolution as they help revolution in South Vietnam via North Vietnam. There is not one single Chinese soldier in South Vietnam. There never will be, unless there is massive intervention by the Western powers which justifies their massive intervention... They are able to get proxies to carry the torch of revolution with tremendous fervor and zeal." ${ }^{\text {6r }}$

Singapore's attitude towards China was the same as that towards Indonesia. "We want to be friends with our neighbours in Asia, whether it is the biggest nation in the world in population like China, or the biggest in Asia like Indonesia", on the basis of "mutual respect for each other's internal sovereignty and integrity and no interference in each other's internal affairs." Lee was glad that this time Beijing did not comment 
on Singapore's separation from Malaysia (unlike during the merger) and thought that this silence augured well for the future. In late-I965, China's admission to the UN was being debated at the United Nations. Singapore supported Chinese admission to the UN by a simple vote or by a two-third majority and "without placing conditions," because in his view, "it is wrong to place conditions." Indeed he believed that China should never have been isolated. ${ }^{62}$ However, Lee had not yet decided on the "Two Chinas" policy. While he agreed that the issue was an outstanding one, there was still no hurry to reach a decision. "Once China is admitted (to the UN), the government takes its place as the representative of the Chinese people. And whether the people in Taiwan are part of the Chinese people, or decide not to be part of the Chinese people... that is a matter to be decided at a later stage. My position is completely open on this." When the time comes for Singapore to make that decision, it would be based on three criteria: (I) what is right, (2) how the decision would affect the interests of Singapore, and (3) how the interests of Singapore could be advanced (meaning: Singapore's survival and capacity to prosper and to expand its trading and other relations with the international community) while doing what was right. ${ }^{63}$ Almost a year after Singapore became independent, Beijing still had not recognised Singapore. But it also did not condemn the country. The Chinese had expressed their wish to trade with Singapore, which Lee did not object to. ${ }^{64}$ Singapore was interested in any country that wanted to trade with it, be it Taiwan or China. Referring to Taiwan in I968, he said that Taiwan had a bustling little economy which was bigger than Singapore, and "we are extremely anxious to increase our cooperation with them." ${ }^{65}$ In 1970, Beijing still categorised Singapore as part of British Malaya. Thus, while economic relations with China were "very good," political relations were not. ${ }^{66}$ The establishment of diplomatic relations between Singapore and China was however "absolutely inevitable," but taking into account the concerns of Singapore's neighbours, Singapore would give them "the honour of being first in establishing relations. ${ }^{n 7}$

To Lee, one big power that would never lose interest in Southeast Asia was China and we could not "afford to forget that." The border regions surrounding China were "vital to her and they should be neutral, if not positively friendly. And if you get weak and unstable situations, the manipulation that is possible - not with any military effort, just sheer economic manipulation and you know, the carrot and throw in with the ideological subversion, this would become quite a Balkanised situation." ${ }^{68}$ He believed the Chinese were "determined, as a people, to unify and build a modern, wealthy Chinese nation." When China became prosperous, "good luck to me, because I will be much safer." ${ }^{69}$ He told his American audience that having lost China, they "have got to live with it." China was now run by a group of men who want China to become 
a great power. "Why shouldn't they be great?" he asked. "You can't stop them."70 As for the suggestion that Southeast Asia should be neutralised (a proposal put forward by the Malaysians and subsequently adopted by ASEAN in I97I), Lee did not object. "Of course it is desirable to have a neutral Southeast Asia," but he was sure that even the Prime Minister of Malaysia did not expect the proposal to become a reality anytime soon. His own preference: the more the great powers were interested in this area, the better..$^{71}$ In a later speech, he would describe the idea of the neutralisation of Southeast Asia as an example of creating a "Shangri-la in our minds," "whistling in the dark, through the cemetery of Indochina." But "Shangri-la is not for Southeast Asia unless one seeks the poppy variety." His preference was for a continued presence of all interested powers in the region which could "add to a more stable balance of influence." 72

This is perhaps a good point to pause to consider Lee's thoughts on two significant events during this period which had strategic implications for Singapore and the region: the Vietnam War and the British withdrawal east of Suez. While both events had their own dynamic, they are not unrelated.

\section{On the British withdrawal east of Suez}

From very early, Lee felt very strongly about the need for a continuing British presence in the region. He said: "British policy will for the foreseeable future be one of the most important factors in Southeast Asia one of the most important non-Southeast Asian factors in Southeast Asia. I, for one, will be sorry to see it supplanted by American policy; and it is my hope that what has happened and what is happening in Laos may never find repetition nearer home... To us, who do not want to see Singapore and Malaya slowly engulfed and eroded by the Communists, it is an absolute "must." 73 He would make this point again during the Confrontation. "No man in his right sense doubts that if there were no British bases in Singapore, Confrontation would not have stopped simply at sporadic guerrilla raids, bomb explosions and subversion."74 In March I965, when he was asked whether he expected the possible shifting of the British naval base in the next four or five years, Lee replied that the British bases would "last for quite a long time."75 He was however unwilling to answer a similar question in an interview about a fortnight later. ${ }^{76}$ However, he said that it was not a simple question of wanting to get rid of the British bases and influence in Malaysia. He again cited the ongoing Confrontation. “... As long as British bases in the region - a British presence in the region - enables us to carry on being ourselves, it's all right with us."77 
His views on the importance of the British bases in Singapore never changed. Arthur Cook of the London Daily Mail observed that Lee had "told practically every journalist" that Singapore could not do without the bases. The Prime Minister did not dispute this. According to Lee, more than 50,000 people's livelihood depended on the bases and that was not counting the "multiplier effect." He believed that there would come a time when the physical presence of British troops would be unnecessary, but "we will have an arrangement whereby, in case of emergency, press button 'A' and tanks, helicopters and rockets, and all the rest, can arrive within a few hours." ${ }^{8}$ But Lee also wanted to ensure that the bases were used only to defend the interests of Singaporeans and Malaysians "that we consider one" as well as Australians and New Zealanders: "people who have been friendly to us, who are very close to us because of geographic proximity and historic experiences," and not as "jumping-points for aggression” against China or Indonesia. Singapore, Lee emphasised was not Guantanamo.79

The issue of the British bases was more than just their importance for the security and economic well-being of Singapore. At another level, Lee was concerned about the emerging danger brought about by "Britain's growing disillusionment" of its defence role east of Suez. By relinquishing its role, the British would not be able to serve as a countervailing role against the United States. Lee was very wary of the US during this period. He told the foreign correspondents, “... I will be quite frank with you. If the British withdraw, I am prepared to go with the Australians and the New Zealanders. But I am not prepared to go on with the Americans." He repeated this a few times during the interview: “... It is fundamental. If the British bases go, there will be no American bases in Singapore. This is a matter of the utmost importance for Britain, Australia, New Zealand, and for America to understand that." 80 Lee found Americans a "highly intelligent" and "often well-meaning" people and some American leaders such as the late-President Kennedy displayed "growing greatness and depth." But by and large, he felt that the American administration lacked depth, a point he reiterated during the interview, and "wisdom which comes out of an accumulation of knowledge of human beings and human situations over a long period of time." ${ }^{81}$ The Americans had enormous wealth and power, "but one thing they cannot buy; and that is a corps of men who understand human beings and human situations." Because of their lack of experience, he was convinced that that the Americans could not defend nor protect Southeast Asia from the communist threat emanating from Vietnam (the Domino Theory). He was extremely scathing of the American management of the situation in Vietnam. "They don't understand the overseas Chinese. They don't understand the Vietnamese. That is what [why?] it is such a mess." He thought that in I963, after the death of Diem, the Americans could have worked towards reaching 
an accommodation with the Vietnamese communists in the South. But they did not, and "that was your last get-off point." ${ }^{82}$

Lee was adamant that in the long-term interests of the region there should not be any "permanent occupation or permanent establishment of American occupation forces or armed forces in South and Southeast Asia." And the only way to ensure this was to have a solution which ensured that what was happening in South Vietnam could not be repeated, even after a lapse of time. If there was a possibility that the situation in South Vietnam could be repeated, "then the countries in the peripheral regions may well prefer some permanent American military presence to self-respect." ${ }^{3}$ He remained consistent in his view, even though in I97I his relationship with the US had improved considerably. "We do not want a US base in Singapore... I do not want a Russian base, nor do I want a US base," he stated categorically. ${ }^{84}$

Lee was very attentive to the psychological dimension of international relations which he would highlight on a number of occasions. When the British finally withdrew from east of Suez in I97I and the security of Singapore, Malaysia, Australia and New Zealand was replaced by the Five-Power Joint Defence Arrangement (FPDA), Lee placed greater emphasis on the "psychological impact more than the realities of the fivepower." ${ }^{85}$ Another notable instance was after the I968 Tet Offensive, Lee reminded his audience that "the greatest danger in Southeast Asia - as in many parts of the world - is that the battle is lost by people, because the people who could lead and fight the battle do a little bit of arithmetic and decide that the odds are not worth taking and therefore never lead to fight the battle." 86

\section{On the United States and the Vietnam War}

We now turn to the Vietnam War, a subject to which Lee also paid a lot of attention. In his words, "Every day, you read the newspapers, and so do I. And the first page that I turn to is South Vietnam, foreign news, South Vietnam." ${ }^{87}$ Lee described the problem facing South Vietnam as "a crucial issue." 88 On another occasion, he said that "the fate of Asia - ${ }^{89}$ South and Southeast Asia - will be decided in the next few years by what happens out in Vietnam... that is the contest..."

Although Lee's views of the Vietnam conflict over the years have been extensively reported, they have not been properly reflected by journalists and political commentators. One of his earliest comments on the conflict in Indochina was a passing remark he made in a I962 speech to the Royal Society of International Affairs (London) in which he was critical of American handling of the situation in Laos, which at this time, was more important than what was happening in Vietnam. He expressed the hope 
that "what has happened and what is happening in Laos may never find repetition nearer home." ${ }^{\circ}$ His first direct comment on Vietnam was in a speech at Canterbury University (Christchurch, New Zealand) in which he said that South Vietnam was part of the region and if what happened there could be repeated in all the neighbouring countries, "then in a matter of a decade or even less if some of the intervening states between Malaysia and South Vietnam decide to anticipate history and be sure that they are on the side that appears like winning, then the whole region will be unscrambled and it would not be long before the Australians find themselves in difficulties." ${ }^{\text {I }}$ He was worried that the West was not "sufficiently alive to the acuteness of the conflicts which have now shifted to Southeast Asia." He found the West "in disarray." He saw the Americans as committed to containment with their military bases in Formosa, South Korea, Vietnam and the Philippines but "to contain what we sometimes fear is the uncontainable." He saw the British, as playing "a secondary role, partly committed to contain, and partly hoping to strike out in some new more positive direction." He lauded Whitehall for its "intelligent move when they exchanged diplomatic representation with China..." and posed the question that had the Americans adopted the same policy, "there might be very little to choose between President Ho Chi Minh and President Tito of Yugoslavia." He found the French solution of neutrality as the panacea for all the ills of Southeast Asia dubious. As for the Dutch and Germans, who were helping Indonesia to restore their economy, he wondered if they could be "so completely and blissfully unaware that both Beijing and Moscow agreed that the Indonesians should be helped "to put Malaysia into a situation like Vietnam and Laos."92

While Lee was sympathetic towards the South Vietnamese cause, he was equally critical of the regime there. In his speech during the debate on the provision for the External Affairs Ministry in the Dewan Ra'ayat in I964, he supported the Malaysian government in establishing an embassy in South Vietnam (and also in South Korea) as telling the world that "we believe that if your neighbor is a Communist, he has no right either by subversion or by military might to overcome you." But he also made the point that, "we should also let it be known that we would prefer to have forms of government far more liberal, far more democratic, far more tolerant than the regimes in Korea and or South Vietnam, but such a tolerant democratic regime is only possible when your neighbor leaves you in peace." 93 While he was careful not to pass judgement on the efforts of the South Vietnamese in public, he did make the point that it would be more effective if either the President or Vice-President of South Vietnam or the Prime Minister were to come forward to explain their situation to the world and not leave it all to the Americans to do it for them. At the same time, he also found the Americans having "a friendly habit of trying to help a person think for himself," a trait which he did not particularly 
like. ${ }^{94}$ He would prefer more selective use of America's enormous range of weapons, more brains and feet, preferably Vietnamese brains and feet, rather than more power and gadgetry." 95

He believed that Beijing was trying to spread communism in Southeast Asia "by proxy" and in his assessment, was doing so effectively through the Vietnamese communists. "It's not Chinese fighting the South Vietnamese; South Vietnamese who believe in Communism are fighting on behalf of world Communism against the South Vietnam Army..." In one interview, he said he did not believe in the simple theory that the Chinese would "send their armies across and eat up Southeast Asia." That would be "naked aggression" and the "whole of Southeast Asia would jell together and meet an incoming invader." "But you have got this "Make it yourself kind of revolution'... Wars of national liberation... Here is the text: "We have an instructor. He will teach you how to organise and will slip you a few guns and more if necessary and, if it gets difficult, well, surface-to air missiles and so on." ${ }^{66}$

As for the effectiveness of the air strikes by the US in North Vietnam following the Tonkin Gulf incident in August 1964, Lee thought that it was too difficult to assess at this point. "Everybody keeps their fingers crossed, and say well, just how the next piece of retaliation go." 97 Asked whether he had any solution to the Vietnam problem, he replied that there was "a general lack of optimism about a peaceful and a happy solution. So I think you've just got to try and find some solution, peaceful or otherwise, which will at least prevent the patterns from being repeated one after the other in Southeast Asia." ${ }^{98}$ Although Lee did not use the term 'Domino Theory,' he once told a journalist when asked for his opinion of the validity of the theory, "first, I don't play dominoes. So don't know what happens with dominoes." 99 Yet the scenario he painted essentially refers to it: "If the Americans decide to pack it up because the position is untenable in South Vietnam and the arena of conflict moves from South Vietnam across to Cambodia into Thailand; and if the Thais with their very keen sense of anticipation of history, decide not to resist the irresistible - or what they deem to be irresistible - then, it is very pertinent what happens to the 500 armed Communists wandering around the borders of Thailand and Malaysia. And, if Malaysia cannot be held, then Singapore must make adjustments accordingly. These then, are the major imponderables..."

He subsequently elaborated on this conundrum in a May I965 speech, which was his most detailed comment on the Vietnam problem to date: "We know that if the Communists are able to advance their frontiers to envelop South Vietnam it will be only a matter of time before the same process of emasculation by military and political techniques will overtake the neighbouring countries. On the other hand, we know that any extension or escalation of the war is dangerous and contrary to the ideals we 
claim to espouse. We have been unable to advance a more constructive alternative than to talk of unconditional negotiations hoping that negotiations may lead to a neutral South Vietnam. However, we know that this is hardly likely to be the end-result of negotiations. For what is required to keep the rest of Southeast Asia free from going through similar tribulations is not just a neutral South Vietnam. As Asians we must uphold the right of the Vietnamese people to self-determination. As democratic socialists we must insist that South Vietnamese have the right not to be pressured through armed might and organised terror and finally overwhelmed by Communism. So we must seek a formula that will first make it possible for South Vietnam to recover their freedom of choice which at the moment is limited to either Communist capture or perpetual American military operations. Then after the South Vietnamese are able to exercise their collective will without duress from either side, ultimately, be it after five, ten or twenty years, they must have the right to decide their final destiny, whether or not they choose to be reunited with North Vietnam and on what terms."

From August to December 1965, the situation in Vietnam changed considerably as the American commitment increased. Lee's views on the situation however remained the same. Lee felt that the situation was "very grim," because both the will and the capacity to resist were largely imported. He hoped that the Americans were not just buying time but would be able to "do something besides just shooting everybody up." He hoped that "a coherent self will emerge consisting of Vietnamese" and that the South Vietnamese could determine whether to merge with the North or stay distinct and separate. "The first prerequisite is that nobody should impose a solution on South Vietnam as to what South Vietnam should do."

It is worth comparing Lee's May 1965 speech on Vietnam with another long response he gave about six years later in I97I (which was almost a year since the war expanded into Cambodia) quoted in full here: “... now if South Vietnam is gone, so too goes Cambodia and Laos. Then the heat is immediately on the Thais, much faster than if only South Vietnam had gone with Cambodia and Laos as buffers for some time still to come." Asked whether that would mean a Chinese communist takeover of Thailand, Malaysia and Singapore, Lee replied, "I do not think things happen in that way. This is not a war that is lost or won decisively in pitched battles. It is relentless process of attrition. Which side has got the greater stamina? Who has the most patience? Whose weight is going to bear in the long run? I don't see Russia or China reaching the technological levels and wealth of the Americans. But it does not mean that because you have the wealth and technology, your power is therefore felt all around the world... if China decides that they should concentrate their power and influence on the littoral states of Asia, they can bring 
considerable bear in these areas. It is a gradual and relentless process. It is not going to happen overnight. There are many ponderables..." ${ }^{\text {"os }}$

Lee was rather disparaging about the various attempts to broker a peaceful end to the Vietnam War: "No amount of peace missions as of now (1966) is going to produce even a sausage," because the war was "a contest of wills." He expected the "process of attrition" to continue ${ }^{\mathrm{IO4}}$ until such time when both sides were convinced that they were "just bleeding to death on a stalemate." Hanoi's non-negotiable pre-condition for talks was that the Americans must first stop bombing the North. Should the United States cease the bombing of the North? Lee's answer was that "all moral, right-thinking human beings would want all bombing to stop. And, it will be inhuman of me to say I want the bombing to go on - it is just utter madness. But, I think a lot of people must ask themselves "what is the end of this road? Is the bombing the end of the road?" The bombing cannot be the end of the road. Therefore, we must know whether the cessation of bombing - the beginning of the stalemate had been reached - recognition by both sides..." ${ }^{\text {Ios }}$ In Lee's assessment, bombing North Vietnam would not end the war, as the Vietnamese communists would run to the mountains. The bombing could be reduced or stopped without any decisive change in the course of the war and it is not a given that the North Vietnamese would go to the conference table once the bombing stopped. ${ }^{\text {106 }}$

While Lee remained consistently critical of American management of the Vietnam War and opposed the idea of a permanent US base in Singapore to replace the British, he also realised the need for an American presence in Vietnam and Southeast Asia because of the British pull-out from the region. As he put it, while "the smaller countries in Southeast Asia would prefer the comfort of their own separate selves," that would only be possible "if there are countervailing forces to enable them not to fall into the orbit of the lager powers in the continent." ${ }^{107} \mathrm{He}$ did not think that Vietnam was "the best place in Asia or Southeast Asia to have taken a stand." The Americans drew the line in South Vietnam because, as he noted in 1965 , they were ignorant of Vietnam and the region. Furthermore, an open society like the United States was not suited to fighting a protracted war. As he told the journalists Peter Simms and Louis Kraal, "you've gone in and raised the stakes with every commitment, increasing the price that you will have to pay for failure to live up to your declared objectives. The worry is whether your open society will allow you to conduct the kind of battle the South Vietnamese war is going to become - a protracted, bitter battle with no prospects of spectacular or decisive victory. The danger of popular pressures growing up around your institutions of power, your Presidency and your Congress for swift and decisive victory, is the greatest danger in your Vietnamese situation. If you can just hold the situation and prevent the other side from winning, you 
would have made a valuable contribution to the long-term stability of the region. If you cannot resist pressures for more intense effort and quicker results, then I see grave trouble for the whole of Asia, for the whole world." ${ }^{108}$ Citing what happened in Aden as an example, Lee was of the view that it was not wise to have a timetable for American withdrawal as "it is better to have these things assessed quietly in qualitative terms and not in quantitative time-tables." ${ }^{\circ}$ o9

In I968, Lee already anticipated that "long before I975, there would be a decisive change in the situation in South Vietnam, and depending on how the Vietnam War was resolved, the rest of Southeast Asia would "fall into place..." Iо Indeed, the decisive change came in less than a year after Lee made his forecast. The Tet Offensive which began on 30 January I968 was one of the turning points of the Vietnam War. On I3 May I968, the opening session of the peace talks was convened in Paris. Lee was of the view that the best one could hope for was a solution which would enable the South Vietnamese - communist and non-communists - to express their will freely in choosing their government. This could only be achieved after a stage-by-stage withdrawal of both North Vietnamese and American troops and "perhaps with the help of some international peace-keeping force." ${ }^{\text {III }}$ When President Nixon said that he would have peace in Vietnam with honour, Lee said in an interview, "How can you have honour unless you do not abandon those whom you have persuaded to go into battle with you?" In another interview on this topic of peace with honour, Lee said that while the US might have disengaged from Vietnam in an honourable way, "whether there is peace in Vietnam is another matter." "I2 Lee never expected the Vietnam War to end the way it did in April I975: "But I would like frankly to say that perhaps never in all our scenarios that we envisaged such a catastrophic collapse of will and morale which led to this terrible disaster." ${ }^{\prime \prime 3}$

In a 4 April I975 speech, Lee said that there was little anyone could do except to "watch the tragedy in Indochina work itself to its bitter end." He hoped Thailand (now under a popularly-elected civilian administration) might resolve its economic and social problems faster than communist subversion could be fomented. The rest of Southeast Asia would have to live with whatever political accommodation Bangkok made. He believed that Malaysia, Singapore and Indonesia ("the secondary areas to the conflict in Indochina") had become more stable and viable in the last decade. The Philippines was still beset by insurgency problems, but he hoped that that could be resolved in time. Also, the five countries were now linked into "a cooperative framework" which was ASEAN. ${ }^{\text {II }}$ Lee's views here may appear contradictory. So would there be or would there not be a communist threat to the non-communist Southeast Asia countries post-US withdrawal from Vietnam? If one reads Lee's speeches carefully, the answer could not be a simple yes or no, but would have to 
depend on whether both North and South Vietnam observed the terms of the Paris Peace Agreements, and to what extent. The course of events and scenarios could not be easily predictable, but the bottom line was that the continued American presence in the region post-withdrawal from Vietnam was absolutely essential. "The countries in Southeast Asia watching the mood in America and reading Senator McGovern's policy to quit Southeast Asia immediately, started re-examining their security positions," Lee revealed. ${ }^{\mathrm{II}}$

\section{On the nature of international politics (1971-1975)}

There were signs that the international architecture of Southeast Asia was on the cusp of change, beginning with the July I97I announcement of Henry Kissinger's (until then) secret visits to Beijing and Nixon's impending trip to China; China's admission to the UN in October 197I; Nixon announcement in January 1972 of the withdrawal of another 70,000 troops from South Vietnam by I July I972, thereby bringing down the number of US troops there to 69,000 and his revelation of the on-going secret meetings between Kissinger and Le Duc Tho; Nixon's visit to Beijing and Moscow in February and May 1972 respectively, and the signing of the Paris Peace Agreement in January 1973, which all combined to make it possible for the US to disengage from Vietnam. By the I970s, the region had also become more integrated and "the survival and political integrity of each country will affect the security and perhaps even the survival of the others." "I6 "The world," Lee said, "is too inter-dependent for any country to insulate itself from the rest of the world..."Ir

Lee expected that in "the next few years, survival under ever changing economic, political and security conditions" would be one of the major concerns for the region. "The disengagement of American forces from Indochina ends one phase in the history of the region... For all of us in ASEAN, this is a period of intermission, waiting for the end of one phase of history, and the start of another, we hope, more promising era," he said. ${ }^{\mathrm{I}}{ }^{8} \mathrm{He}$ saw the end of the Vietnam War marking a new phase in the politics of Southeast Asia and indeed of the world. In his analysis, the Paris Peace Agreement was a consequence of "the new direct relations the great powers are establishing between themselves, over the heads of small nations." "II Lee also drew attention to Moscow giving Nixon a red carpet welcome despite American bombing of Hanoi and Haiphong in spring $1972 .{ }^{120}$ For small nations, the great powers were no longer "moved by ideological considerations." Their main concern was "the safeguarding and maximising of their national interests." This fundamental change therefore required a "rethinking and reformulation of the content of the concepts of non-alignment," and for small 
countries, such as Singapore, "the question now is not how to avoid being sucked into the warring camps of the two great powers, but how to have their interests taken into consideration when the great powers reach their compromises." ${ }^{\text {I21 }}$ All the above ideas were expanded and fleshed out in a series of three Jacob Blaustein lectures on international relations which Lee delivered in March-April I973 at Leigh University (Bethlehem, Pennsylvania). ${ }^{122}$ Most memorably, Lee recalled the African proverb: when elephants fight, the grass suffers, and added that when elephants flirt, the grass also suffers. "And, when they make love, it is disastrous." ${ }^{223}$

The central question was thus how the Southeast Asian countries should act to secure their interests in a multi-polar world. Much would depend on Washington's "political nerve and diplomatic skill," not in reducing her influence in the region faster than necessary. Equally important, the ASEAN countries must recognise that they have common interests and not do anything that could harm these interests and allow the great powers to exploit them. "If the countries of Southeast Asia, whatever the differences and conflicts between themselves, can place their group interest beyond such interventions," then non-communist Southeast Asia would have "a fair chance of preserving the maximum of freedom of choice provided by a balance between the great powers," Lee concluded. ${ }^{\text {I24 }}$

On the same day that Saigon fell (on 30 April I975), bringing the Vietnam War finally to an end, Lee in his speech at the Commonwealth Heads of Government meeting, (Kingston, Jamaica) described I973-I974 as "two of the most momentous years of the history of the world since World War II" and "a turning point in history." He declared that "it is power, and the use or non-use of power" that would decide the destiny of the world. It is the power of the Americans and the Russians, and later of the Chinese, and "how they restrain themselves and their allies, that will decide the framework of peace plus competition for influence." And within this context, Southeast Asia would have to chart its future postVietnam. $^{\text {I25 }}$

\section{Conclusion}

This chapter hopefully provides a different way of understanding Singapore's foreign policy - not so much at the operational level or the decision-making process, which it is unfortunately still not possible to reconstruct because of lack of access to the relevant archives. As Louis Halle said, "what the foreign policy of any nation addresses is the image of the external world in the minds of the people who determine the policy of that nation" (Halle I960: 316). In the case of Singapore, it is surely the worldview of Lee Kuan Yew that had been most influential. Contextualising 
his thoughts as they evolved is to acknowledge that human beings would always be unable to completely distance themselves from the emotionally and politically charged atmosphere of their time. This is only the first of a longer systematic treatment of Lee's life-time of thoughts on international affairs, which must have been shaped - and continues to be shaped - by both contemplation and experience. Lee has this uncanny ability to foresee the political trends which must have helped Singapore to be so nimble in the conduct of its foreign relations. It might be worth reading this chapter in conjunction with Lee's memoirs. As these were written many years after the events they describe, they are definitely more reflective. By including Lee's summing up of his experience in this chapter, I have allowed his words to speak for themselves. Letting his thoughts come alive in this way will hopefully illuminate the framework of his Singapore story.

\section{Notes}

I There is no consensus as to the starting point of the First Cold War. Most scholars consider the origins to be in the years immediately after the Second World War. For Southeast Asia, I949 is usually considered the starting point. The Second Cold War is generally thought to have to been from I979 to I985. For Southeast Asia, this coincided with the Vietnamese invasion of Cambodia in December I978. This chapter concludes with the end of the Vietnam War in I975. The two years following the end of that war up to the Vietnamese invasion of Cambodia can best be studied as part of the Second Cold War in Southeast Asia.

2 Transcript of a speech by the Prime Minister, Mr. Lee Kuan Yew, at a seminar on "International Relations", held at the University of Singapore, 9 October I966, lky/ı966/ lkyıooga.doc, http: //stars.nhb.gov.sg/stars/public/

3 Email correspondence with Professor Bernard Loo of the S. Rajaratnam School of Strategic Studies (RSIS), Singapore on I6 October 2009.

4 John Chipman in his introduction to Lee Kuan Yew's address to the International Institute of Strategic Studies (London), 23 September 2008, http: //www.iiss.org/recentkey-addresses/lee-kuan-yew-address/

5 James Schlesinger's introductory remarks at the I996 Architect of the New Century Dinner Honouring Lee Kuan Yew, http: //www.nixoncenter.org/publications/YEW 96.html

6 Henry Kissinger's introductory remarks at the I996 Architect of the New Century Dinner Honouring Lee Kuan Yew, http: //www.nixoncenter.org/publications/YEW96.html

7 http: //stars.nhb.gov.sg/stars/public/

8 Address by Mr. Lee Kuan Yew, Prime Minister of Singapore, at the Asia Society Dinner, New York Hilton, I2 May I975, 1ky/I975/lkyo5ı2a.doc, http: //stars.nhb.gov.sg/stars/ public/

9 Speech of Singapore's Prime Minister, Mr. Lee Kuan Yew, during the debate on cut-motion on the provision of External Affairs Ministry in the Dewan Ra'ayat, I6 December I964, lkyı964lkyı2ı6.doc, http: //stars.nhb.gov.sg/stars/public/

Io Transcript of 'The Future of Malaysia', a speech given by the Prime Minister of Singapore, Mr. Lee Kuan Yew, at Assembly Hall, Melbourne, Australia, 24 March I965 to the Institute of International Affairs, lkyi965lkyo324a.doc, http: //stars.nhb.gov.sg/stars/public/ 
II Transcript of 'The Future of Malaysia', a speech given by the Prime Minister of Singapore, Mr. Lee Kuan Yew, at Assembly Hall, Melbourne, Australia, 24 March I965 to the Institute of International Affairs, lkyig65lkyo324a.doc, http: //stars.nhb.gov.sg/stars/public/

I2 Transcript of speech by the Prime Minister at the Foreign Correspondents Associations' Dinner in Tokyo, 2I March I967, lky/1967/lky0321.doc, http: //stars.nhb.gov.sg/ stars/public/; Address by the Prime Minister, Mr. Lee Kuan Yew, at the $3^{\text {rd }}$ International Forum of the Friedrich-Ebert Stiftung in Tokyo, 22 March I967, 1ky/1967/lkyo322.doc, http: //stars.nhb.gov.sg/stars/public/

I3 Address by Mr. Lee Kuan Yew, Prime Minister of Singapore, at the Asia Society Dinner, New York Hilton, I2 May I975, lky/i975/lkyo5I2a.doc, http: //stars.nhb.gov.sg/stars/ public/

I4 The Prime Minister, Mr. Lee Kuan Yew's address at the Parliamentary Luncheon, Wellington, 4 April I975, lky/I975/lky0404.doc, http: //stars.nhb.gov.sg/stars/public/

I5 Prime Minister meets foreign correspondents at Television Singapore, 5 November ${ }_{19} 67$, lky/1967/lkyıro5a.doc, http: //stars.nhb.gov.sg/stars/public/

I6 Meet the Press, produced by Lawrence E. Spivak, 22 October I967, lky/1967/lkyı 22. doc, http: //stars.nhb.gov.sg/stars/public/

I7 The Year Ahead, lkyi956lkyı200.doc, http: //stars.nhb.gov.sg/stars/public/

I8 Prime Minister's Speech for Foreign Correspondents' Association, I6 September I959, lky/ı959/lkyogi6.doc, http: //stars.nhb.gov.sg/stars/public/

I9 The Prime Minister, Mr. Lee Kuan Yew's own impressions on his tour recorded by BBC for Radio Singapore, to be broadcast at Io pm, Sunday, 20 May I962, lky/1962/ lkyo520.doc, http: //stars.nhb.gov.sg/stars/public/

20 Speech by Singapore Prime Minister and Secretary-General of the People's Action Party, Mr. Lee Kuan Yew, in the debate on East-West Relations at the Socialist International Conference Council, Brussels, 3 September ig64, lkyig64lkyo903.doc, http: // stars.nhb.gov.sg/stars/public/

2I Prime Minister's Press Conference held on 26 August I965 at City Hall, lkyI965lkyo826.doc, http: //stars.nhb.gov.sg/stars/public/

22 Transcript of a press conference of the Prime Minister, Mr. Lee Kuan Yew, gave to a group of Foreign correspondents at the Television Singapura Studio, in December 1965, lkyı965lkyı2ırb.doc, http: //stars.nhb.gov.sg/stars/public/

23 Translations of the Prime Minister's speech in Hokkien at the $I^{\text {st }}$ Anniversary Celebrations of the Upper Serangoon Community Centre, 26 September 1965, lkyI965lkyo926.doc, http: //stars.nhb.gov.sg/stars/public/

24 Transcript of Speech by the Prime Minister of Singapore, Mr. Lee Kuan Yew, to students of Canterbury University, Christchurch, New Zealand, I5 March I964, lky/1964lkyo3i5b.doc, http: //stars.nhb.gov.sg/stars/public/

25 Transcript of Speech by the Prime Minister of Singapore, Mr. Lee Kuan Yew, to students of Canterbury University, Christchurch, New Zealand, I5 March 1964, lky/I964lkyo3i5b.doc, http: //stars.nhb.gov.sg/stars/public/

26 Translations of the Prime Minister's speech in Hokkien at the $\mathrm{I}^{\text {st }}$ anniversary celebrations of the Upper Serangoon Community Centre on 26 September I965, lkyI965lkyo926.doc, http: //stars.nhb.gov.sg/stars/public/

27 "One hundred Days of Singapore's Independence", Transcript of an interview with the Prime Minister by Jackie Sam of the Straits Times Press and Wu Shih of Sin Chew Jit Poh, held at the Prime Minister's Office, I6 November i965, lkyı 965lkyıiı6a.doc, http: //stars.nhb.gov.sg/stars/public/

28 Transcript of a television interview with the Prime Minister, Mr. Lee Kuan Yew, by three foreign press correspondents, Mr. Creighton Burns of the Melbourne Age, Mr. Nihal Singh of the Statesman of India, and Mr. Dennis Bloodworth of the London Observer, recorded at the studios of Television Singapura, 28 July ig66, 1ky/ig66/lkyo728.doc, http: //stars. nhb.gov.sg/stars/public/ 
29 Broadcast Excerpts from an address given by the Prime Minister, Mr. Lee Kuan Yew, on "Changing Values in a Shrinking World" at the Political Study Centre, I3 July I966, lky/ı966/lkyo7ı3.doc, http: //stars.nhb.gov.sg/stars/public/

30 "One hundred Days of Singapore's Independence", Transcript of an interview with the Prime Minister by Jackie Sam of the Straits Times Press and Wu Shih of Sin Chew Jit Poh, held at the Prime Minister's Office, I6 November i965, lkyı965lkyıı16a.doc, http: //stars.nhb.gov.sg/stars/public/

3I Transcript of a press conference of the Prime Minister, Mr. Lee Kuan Yew, gave to a group of Foreign correspondents at the Television Singapura Studio, II December I965, lkyı965lkyı2ııb.doc, http: //stars.nhb.gov.sg/stars/public/

32 Prime Minister's Press Conference held on 26 August I965 at City Hall, lkyig65lkyo826.doc, http: //stars.nhb.gov.sg/stars/public/

33 Transcript of a Speech by the Prime Minister, Mr. Lee Kuan Yew, at the Chinese Chamber of Commerce, 4 July i966, 1ky/ı966/lkyo704.doc, http: //stars.nhb.gov.sg/stars/ public/

34 Transcript of a press conference given by the Prime Minister, Mr. Lee Kuan Yew, Hydrabad House, New Delhi, 3 September i966, lky/ı966/lkyo9o3c.doc, http: //stars. nhb.gov.sg/stars/public/

35 Transcript of a speech by the Prime Minister, Mr. Lee Kuan Yew, at a seminar on "International Relations", held at the University of Singapore, 9 October ig66, lky/ig66/ lkyiooga.doc,

36 Prime Minister's Speech at the State Banquet, lky/ıg6o/lkyoııgb.doc, http: //stars. nhb.gov.sg/stars/public/

37 Prime Minister's Speech for the Chinese Chamber of Commerce Reception to be held on 8 August I959, lky/I959/lkyo808.doc, http: //stars.nhb.gov.sg/stars/public/; Lee reiterated this point in Transcript of the question and answer session following the address by the Prime Minister, Mr. Lee Kuan Yew, to the Foreign Correspondents' Club, I9 February I970, lkyı970lkyo2I9b.doc, http: //stars.nhb.gov.sg/stars/public/

38 Speech by the Minister for Foreign Affairs (Mr. S Rajaratnam) delivered in Parliament on I6 December I965 in Parliamentary Debates, Republic of Singapore, Official Report, First Session of the First Parliament, Part 1 of First Session, Volume 24.

39 "One hundred Days of Singapore's Independence", Transcript of an interview with the Prime Minister by Jackie Sam of the Straits Times Press and Wu Shih of Sin Chew Jit Poh, held at the Prime Minister's Office, I6 November I965, lkyı965lkyıı16a.doc, http: //stars.nhb.gov.sg/stars/public/

40 Prime Minister's Press Conference held on 26 August I965 at City Hall, lkyI965lkyo826.doc, http: //stars.nhb.gov.sg/stars/public/; For an overview of the basic thrust and philosophy of Singapore's foreign policy, see Speech by the Minister for Foreign Affairs (Mr. S Rajaratnam) delivered in Parliament on I6 December I965 in Parliamentary Debates, Republic of Singapore, Official Report, First Session of the First Parliament, Part 1 of First Session, Volume 24; Transcript of a television interview with the Prime Minister, Mr. Lee Kuan Yew, by three foreign press correspondents, Mr. Creighton Burns of the Melbourne Age, Mr. Nihal Singh of the Statesman of India, and Mr. Dennis Bloodworth of the London Observer, recorded at the studios of Television Singapura, 28 July I966, lky/i966/lkyo728.doc, http: //stars.nhb.gov.sg/stars/public/

4I Transcript of a press conference of the Prime Minister, Mr. Lee Kuan Yew, gave to a group of Foreign correspondents at the Television Singapura Studio, II December I965, lkyı965lkyı2ııb.doc, http: //stars.nhb.gov.sg/stars/public/

42 Transcript of a press conference of the Prime Minister, Mr. Lee Kuan Yew, gave to a group of Foreign correspondents at the Television Singapura Studio, II December I965, lkyı965lkyı2ıib.doc, http: //stars.nhb.gov.sg/stars/public/

43 Transcript of Television interview - The Prime Minister being interviewed by Derek Round, Reuters; John Hughes, Christian Science Monitor; and Ken Jalleh, Hong Kong 
Standard at the Peninsula Hotel, Hong Kong, I4 October I968, lkyıg68lkyı I4.doc, http: //stars.nhb.gov.sg/stars/public/

44 "One hundred Days of Singapore's Independence", Transcript of an interview with the Prime Minister by Jackie Sam of the Straits Times Press and Wu Shih of Sin Chew Jit Poh, held at the Prime Minister's Office, I6 November i965, lkyig65lkyiri6a.doc, http: //stars.nhb.gov.sg/stars/public/

45 Transcript of a press conference of the Prime Minister, Mr. Lee Kuan Yew, gave to a group of Foreign correspondents at the Television Singapura Studio, II December 1965, lkyI965lkyı21rb.doc, http: //stars.nhb.gov.sg/stars/public/

46 Transcript of a press conference of the Prime Minister, Mr. Lee Kuan Yew, gave to a group of Foreign correspondents at the Television Singapura Studio, II December 1965, lkyI965lkyi2IIb.doc, http: //stars.nhb.gov.sg/stars/public/

47 Transcript of a press conference of the Prime Minister, Mr. Lee Kuan Yew, gave to a group of Foreign correspondents at the Television Singapura Studio, in December I965, lkyig65lkyi2ırb.doc, http: //stars.nhb.gov.sg/stars/public/

48 Transcript of a press conference of the Prime Minister, Mr. Lee Kuan Yew, gave to a group of Foreign correspondents at the Television Singapura Studio, in December I965, lkyig65lkyi2IIb.doc, http: //stars.nhb.gov.sg/stars/public/

49 Transcript of a press conference of the Prime Minister, Mr. Lee Kuan Yew, gave to a group of Foreign correspondents at the Television Singapura Studio, in December I965, lkyı655lkyı2ırb.doc, http: //stars.nhb.gov.sg/stars/public/

50 Broadcast Excerpts from an address given by the Prime Minister, Mr. Lee Kuan Yew, on "Changing Values in a Shrinking World" at the Political Study Centre, I3 July I966, lky/ig66/lkyo7ı3.doc, http: //stars.nhb.gov.sg/stars/public/; Also see, Transcript of a speech by the Prime Minister, Mr. Lee Kuan Yew, at a seminar on "International Relations", held at the University of Singapore, 9 October I966, 1ky/1966/lkyıoo9a.doc,

5I Transcript of a television interview with the Prime Minister, Mr. Lee Kuan Yew, by three foreign press correspondents, Mr. Creighton Burns of the Melbourne Age, Mr. Nihal Singh of the Statesman of India, and Mr. Dennis Bloodworth of the London Observer, recorded at the studios of Television Singapura, 28 July I966, 1ky/ig66/1kyo728.doc; Transcript of a speech by the Prime Minister, Mr. Lee Kuan Yew, at a seminar on "International Relations", held at the University of Singapore, 9 October 1966, 1ky/ig66/ lkyiooga.doc, http: //stars.nhb.gov.sg/stars/public/

52 Transcript of Press Conference given by the Prime Minister at the Singapore Airport prior to his departure on a two-month tour, II April I966, lky/ig66/lkyo4II.doc, http: //stars.nhb.gov.sg/stars/public/

53 Transcript of a talk given by the Prime Minister, Mr. Lee Kuan Yew, on the subject "Big and Small Fishes in Asian Waters" at a meeting of the University of Singapore Democratic Socialist Club at the University campus, I5 June I966, 1ky/1966/lkyo6I5.doc, http: //stars.nhb.gov.sg/stars/public/

54 Transcript of a press conference given by the Prime Minister, Mr. Lee Kuan Yew, Hydrabad House, New Delhi, 3 September I966, lky/ı966/lkyogo3c.doc, http: //stars. nhb.gov.sg/stars/public/

55 Transcript of interview on Vietnam and regional grouping given by Prime Minister to Peter Simms of New York Times and Louis Kraal of the Time Magazine, in April I967, lky/ig67/lkyo4II.doc, http: //stars.nhb.gov.sg/stars/public/

56 Transcript of a press conference given by the Prime Minister, Mr. Lee Kuan Yew, at City Hall to local and foreign correspondents, 2 June I966, lky/1966/lkyo6o2.doc, http: // stars.nhb.gov.sg/stars/public/

57 Transcript of a talk given by the Prime Minister, Mr. Lee Kuan Yew, on the subject "Big and Small Fishes in Asian Waters" at a meeting of the University of Singapore Democratic Socialist Club at the University campus, I5 June I966, lky/1966/lkyo6I5.doc, http: //stars.nhb.gov.sg/stars/public/ 
58 Transcript of the question and answer session following the address by the Prime Minister, Mr. Lee Kuan Yew, to the Foreign Correspondents' Club, I9 February I970, lkyI970lkyo2Igb.doc, http: //stars.nhb.gov.sg/stars/public/

59 Text of interview with the Prime Minister by Kenneth Randall of the Sunday Australian and Douglas Brass of the New Nation, 26 January I97I, lkyı97Ilkyoi26b.doc, http: // stars.nhb.gov.sg/stars/public/

60 Interview with the Prime Minister by Mr. Henry Kamm, New York Times correspondent for Asia, 26 May I97I, lkyi97Ilky0526.doc, http: //stars.nhb.gov.sg/stars/public/

6I Transcript of an interview given by the Prime Minister, Mr. Lee Kuan Yew, at NZBC House, II March I965, lkyig65lkyo3II.doc, http: //stars.nhb.gov.sg/stars/public/

62 Transcript of TV press interview of the Prime Minister, Mr. Lee Kuan Yew, at Palam Airport, New Delhi, 25 November I97I, lkyi97Ilkyiı25.doc, http: //stars.nhb.gov.sg/ stars/public/; See also, Transcript of ITV Colour Television interview with the Prime Minister, Mr. Lee Kuan Yew, by Mr. Emmon Andrews, London, 27 November 1972, lky/1972/lkyıı27.doc, http: //stars.nhb.gov.sg/stars/public/. Asked whether he welcomed the fact that China was now taking a greater place in world affairs, Lee replied that it had to come and the earlier it came about, the better for the rest of the world; and the world got to adjust to the fact that there is this power.

63 "One hundred Days of Singapore's Independence", Transcript of an interview with the Prime Minister by Jackie Sam of the Straits Times Press and Wu Shih of Sin Chew Jit Poh, held at the Prime Minister's Office, I6 November 1965, lkyig65lkyıiı6a.doc, http: //stars.nhb.gov.sg/stars/public/; Also see, Transcript of question and answer session following the Prime Minister's Luncheon Address at the reception given him by the French Diplomatic Press Association, at Hotel George V, Paris, 25 September I970,

64 Transcript of a press conference given by the Prime Minister, Mr. Lee Kuan Yew, at City Hall to local and foreign correspondents, 2 June I966, 1ky/1966/lkyo6o2.doc, http: //stars.nhb.gov.sg/stars/public/

65 Transcript of general press conference given by the Prime Minister, Mr. Lee Kuan Yew, at TV Centre, 2I December I968, lkyig681kyi22Ic.doc. http: //stars.nhb.gov.sg/stars/ public/

66 Transcript of question and answer session following the Prime Minister's Luncheon Address at the reception given him by the French Diplomatic Press Association, at Hotel George V, Paris, 25 September I970,

67 Transcript of press conference given by the Prime Minister in Tokyo, II May I973, lky/I973/lkyo5II.doc, http: //stars.nhb.gov.sg/stars/public/

68 Transcript of an interview with the Prime Minister, Mr. Lee Kuan Yew, by Mr. Anthony Rendell, recorded in London by the Australian Broadcasting Commission, I7 September I966, lky/ig66/lkyo9I7.doc, http: //stars.nhb.gov.sg/stars/public/

69 Meet the Press, produced by Lawrence E. Spivak, 22 October I967, lky/1967/lkyio22. doc, http: //stars.nhb.gov.sg/stars/public/

70 Meet the Press, produced by Lawrence E. Spivak, 22 October 1967 , lky/1967/lkyio22. doc, http: //stars.nhb.gov.sg/stars/public/; See also, Interview with the Prime Minister by Mr. Henry Kamm, New York Times correspondent for Asia, 26 May I97I, lkyI97Ilkyo526.doc, http: //stars.nhb.gov.sg/stars/public/ For a very detailed analysis of China by Lee.

7I Text of interview with the Prime Minister by Kenneth Randall of the Sunday Australian and Douglas Brass of the New Nation, 26 January i97I, lkyig7ilkyoi26b.doc, http: // stars.nhb.gov.sg/stars/public/

72 Excerpts of address by Singapore's Prime Minister, Mr. Lee Kuan Yew, on the Change in Great Power Relations at the Commonwealth meeting in Ottawa, 3 August 1973, lky/1973/lkyo803.doc, http: //stars.nhb.gov.sg/stars/public/

73 Speech by the Prime Minister, Mr. Lee Kuan Yew, at the Royal Society of International Affairs, London, May 1962, lky/1962/lky0500.doc, http: //stars.nhb.gov.sg/stars/public/ 
74 Speech by the Prime Minister, Mr. Lee Kuan Yew, on the motion on National Service at the Legislative Assembly, 5 November i964, lky/ig64/lkyiı 5a.doc, http: //stars.nhb. gov.sg/stars/public/

75 Press Conference given by the Prime Minister of Singapore, Mr. Lee Kuan Yew, in Sydney, 6 March I965, lkyig65lky0306.doc, http: //stars.nhb.gov.sg/stars/public/

76 Transcript of an interview of Mr. Lee Kuan Yew with a staff member of ABC, Alan Ashbolt recorded in Canberra TV Studios, I7 March 1965 broadcast by Radio Malaysia, Singapore, 24 March I965, lkyi965lkyo324c.doc, http: //stars.nhb.gov.sg/stars/public/

77 Transcript of an interview of Mr. Lee Kuan Yew with a staff member of ABC, Alan Ashbolt recorded in Canberra TV Studios, I7 March 1965 broadcast by Radio Malaysia, Singapore, 24 March I965, lkyig65lky0324c.doc, http: //stars.nhb.gov.sg/stars/public/

78 Transcript of an interview by foreign correspondents with the Prime Minister of Singapore, Mr. Lee Kuan Yew, held at TV Singapura at II30 hours, 30 August I965, lkyig65lkyo830.doc, http: //stars.nhb.gov.sg/stars/public/

79 Transcript of an interview by foreign correspondents with the Prime Minister of Singapore, Mr. Lee Kuan Yew, held at TV Singapura at II30 hours, 30 August I965, lkyig65lkyo830.doc, http: //stars.nhb.gov.sg/stars/public/

80 Transcript of an interview by foreign correspondents with the Prime Minister of Singapore, Mr. Lee Kuan Yew, held at TV Singapura at II30 hours, 30 August I965, lkyig65lkyo830.doc, http: //stars.nhb.gov.sg/stars/public/

8I Transcript of an interview by foreign correspondents with the Prime Minister of Singapore, Mr. Lee Kuan Yew, held at TV Singapura at II30 hours, 30 August I965, lkyig65lkyo830.doc, http: //stars.nhb.gov.sg/stars/public/ In this interview, Lee recounted his three rather unfortunate experiences with the Americans. See also, "Singapore: Blasting Off" in Time, Io September 1965; Lee Kuan Yew, From Third World to First: the Singapore Story: 1965-2000, Memoirs of Lee Kuan Yew (Singapore: Times Editions, Singapore Press Holdings, 2000), Chapter 28.

82 Meet the Press, produced by Lawrence E. Spivak, 22 October I967, lky/1967/lkyı 22. doc, http: //stars.nhb.gov.sg/stars/public/

83 Transcript of speech by the Prime Minister at the Foreign Correspondents Associations' Dinner in Tokyo, 2I March I967, lky/1967/lkyo32I.doc, http: //stars.nhb.gov. $\mathrm{sg} /$ stars/public/

84 Transcript of interview with Prime Minister Lee Kuan Yew by Mims Thomson, UPI, I9 March I97I, lkyi97Ilkyo3I9.doc, http: //stars.nhb.gov.sg/stars/public/

85 Transcript of a BBC programme, "Forum", recorded in London, 3 November I97I, lkyI97IlkyıI03.doc, http: //stars.nhb.gov.sg/stars/public/

86 Speech by the Prime Minister, Mr. Lee Kuan Yew, at the Royal Society of International Affairs, London, May I962, lky/1962/lky0500.doc, http: //stars.nhb.gov.sg/stars/public/

87 Transcript of 'The Future of Malaysia', a speech given by the Prime Minister of Singapore, Mr. Lee Kuan Yew, at Assembly Hall, Melbourne, Australia, 24 March 1965 to the Institute of International Affairs, lkyig65lkyo324a.doc, http: //stars.nhb.gov.sg/stars/public/

88 Speech by the Prime Minister, Mr. Lee Kuan Yew, at the opening session of the 1965 Asian Socialist Conference in Bombay, 6 May I965, lkyig65lkyo506.doc, http: //stars. nhb.gov.sg/stars/public/

89 Transcript of the Prime Minister's interview with Dennis Bloodworth of Observer, London, John Bennetts of The Age, Melbourne, and Canberra Times, and Peter Hollingshead of ABC and VisNews at Television Singapura, 5 July I967, lky/ig67/lkyo705.doc, http: //stars.nhb.gov.sg/stars/public/

90 Speech by the Prime Minister, Mr. Lee Kuan Yew, at the Royal Society of International Affairs, London, May 1962, lky/1962/lky0500.doc, http: //stars.nhb.gov.sg/stars/public/

9I Transcript of Speech by the Prime Minister of Singapore, Mr. Lee Kuan Yew, to students of Canterbury University, Christchurch, New Zealand, I5 March I964, lky/1964lkyo3I5b.doc, http: //stars.nhb.gov.sg/stars/public/ 
92 Speech by Singapore Prime Minister and Secretary-General of the People's Action Party, Mr. Lee Kuan Yew, in the debate on East-West Relations at the Socialist International Conference Council, Brussels, 3 September I964, lkyig64lkyo9o3.doc, http: // stars.nhb.gov.sg/stars/public/

93 Speech of Singapore's Prime Minister, Mr. Lee Kuan Yew, during the debate on cut-motion on the provision of External Affairs Ministry in the Dewan Ra'ayat, I6 December i964, lkyi964lkyı2ı6.doc, http: //stars.nhb.gov.sg/stars/public/

94 Meet the Press, produced by Lawrence E. Spivak, 22 October I967, lky/ig67/lkyıo22. doc, http: //stars.nhb.gov.sg/stars/public/

95 Meet the Press, produced by Lawrence E. Spivak, 22 October I967, lky/i967/lkyıo22. doc, http: //stars.nhb.gov.sg/stars/public/

96 Meet the Press, produced by Lawrence E. Spivak, 22 October I967, lky/i967/lkyı 22. doc, http: //stars.nhb.gov.sg/stars/public/; Lee's review remained unchanged in November I97I. See Transcript of a BBC programme, "Forum", recorded in London, 3 November I97I, lkyi97Ilkyıı03.doc, http: //stars.nhb.gov.sg/stars/public/

97 Press Conference given by the Prime Minister of Singapore, Mr. Lee Kuan Yew, in Sydney, 6 March I965, lkyi965lkyo306.doc, http: //stars.nhb.gov.sg/stars/public/

98 Press Conference given by the Prime Minister of Singapore, Mr. Lee Kuan Yew, in Sydney, 6 March I965, lkyi965lkyo306.doc, http: //stars.nhb.gov.sg/stars/public/

99 Prime Minister Interviewed at Television Singapura, 8 November I967, lky/1967/ lkyıı08.doc, http: //stars.nhb.gov.sg/stars/public/

Ioo Transcript of Speech made by the Prime Minister, Mr. Lee Kuan Yew, at a gathering of Singapore and Malaysian students at the International Students House in London, 22 April I966, lky/i966/lkyo422, http: //stars.nhb.gov.sg/stars/public/

IOI Speech by the Prime Minister, Mr. Lee Kuan Yew, at the opening session of the I965 Asian Socialist Conference in Bombay, 6 May i965, lkyig65lkyo506.doc, http: //stars. nhb.gov.sg/stars/public/

IO2 Transcript of a press conference of the Prime Minister, Mr. Lee Kuan Yew, gave to a group of Foreign correspondents at the Television Singapura Studio, II December I965, lkyı965lkyı2ıib.doc, http: //stars.nhb.gov.sg/stars/public/; Transcript of a press conference given by the Prime Minister, Mr. Lee Kuan Yew, at City Hall to local and foreign correspondents, 2 June I966, 1ky/i966/lkyo6o2.doc, http: //stars.nhb.gov.sg/stars/ public/

I03 Transcript of interview with Prime Minister Lee Kuan Yew by Mims Thomson, UPI, I9 March I97I, lkyı97Ilkyo3I9.doc, http: //stars.nhb.gov.sg/stars/public/

IO4 Transcript of an interview with the Prime Minister, Mr. Lee Kuan Yew, by Mr. Anthony Rendell, recorded in London by the Australian Broadcasting Commission, I7 September I966, lky/ig66/lkyo9I7.doc, http: //stars.nhb.gov.sg/stars/public/

I05 Transcript of an interview with the Prime Minister on board an aircraft by Mr. Bernard Kalb, i9 March I967, lky/i967/lkyo3I9.doc, http: //stars.nhb.gov.sg/stars/ public/

Io6 Transcript of an interview with the Prime Minister on board an aircraft by Mr. Bernard Kalb, I9 March I967, lky/I967/lkyo3I9.doc, http: //stars.nhb.gov.sg/stars/public/; Meet the Press, produced by Lawrence E. Spivak, 22 October I967, lky/i967/lkyıo22. doc, http: //stars.nhb.gov.sg/stars/public/

I07 Transcript of interview on Vietnam and regional grouping given by Prime Minister to Peter Simms of New York Times and Louis Kraal of the Time Magazine, II April I967, lky/I967/lkyo4II.doc, http: //stars.nhb.gov.sg/stars/public/; Also see, Transcript of the Prime Minister's interview with Dennis Bloodworth of Observer, London, John Bennetts of The Age, Melbourne, and Canberra Times, and Peter Hollingshead of ABC and VisNews at Television Singapura, 5 July i967, lky/i967/lkyo705.doc, http: //stars.nhb.gov.sg/stars/public/; Transcript of the Prime Minister's interview with Dennis Bloodworth of Observer, London, John Bennetts of The Age, Melbourne, 
and Canberra Times, and Peter Hollingshead of ABC and VisNews at Television Singapura, 5 July I967, lky/1967/lky0705.doc, http: //stars.nhb.gov.sg/stars/public/ Io8 Transcript of interview on Vietnam and regional grouping given by Prime Minister to Peter Simms of New York Times and Louis Kraal of the Time Magazine, II April I967, lky/1967/lkyo4II.doc, http: //stars.nhb.gov.sg/stars/public/

Io9 Statement to the Press in London made by the Prime Minister, Mr. Lee Kuan Yew, I July I967, lky/1967/lkyo70I.doc, http: //stars.nhb.gov.sg/stars/public/; Also see, Transcript of the Prime Minister's interview with Dennis Bloodworth of Observer, London, John Bennetts of The Age, Melbourne, and Canberra Times, and Peter Hollingshead of ABC and VisNews at Television Singapura, 5 July I967, lky/ig67/lky0705.doc, http: //stars.nhb.gov.sg/stars/public/

IIo Statement to the Press in London made by the Prime Minister, Mr. Lee Kuan Yew, I July I967, lky/I967/lkyo70I.doc, http: //stars.nhb.gov.sg/stars/public/

III Exclusive interview given by the Prime Minister to Ray Herndon, UPI Southeast Asia correspondent, 2I December I968, lkyig68lkyi22Ia.doc, http: //stars.nhb.gov.sg/ stars/public/

II2 Transcript of interview given by the Prime Minister of Singapore, Mr. Lee Kuan Yew, at the "Meet the Press" - NBC's TV press conference on the air, New York, II April I973, lky/ig73/lkyo4IIa.doc, http: //stars.nhb.gov.sg/stars/public/

II3 Face the Nation (produced by CBS News, Washington D.C, II May I975, lky/1975/ lkyo5II.doc, http: //stars.nhb.gov.sg/stars/public/

II4 The Prime Minister, Mr. Lee Kuan Yew's address at the Parliamentary Luncheon, Wellington, 4 April I975, lky/I975/lky0404.doc, http: //stars.nhb.gov.sg/stars/public/; Address by Mr. Lee Kuan Yew at the Press Club Luncheon, 7 April I975, Wellington, lky/I975/lkyo407a.doc, http: //stars.nhb.gov.sg/stars/public/

II5 For a detailed exposition of the different scenarios, see Jacob Blaustein Lectures: Lecture III: Security and Stability Essential for Development of New Countries in Southeast Asia, lky/1973/lkyo402.doc, http: //stars.nhb.gov.sg/stars/public/

II6 Speech by the Prime Minister in reply to H.E. Field Marshal Thanom Kittikachorn, Prime Minister of Thailand at a dinner, 8 January I973, 1ky/ig63/lkyoıo8b.doc, http: //stars.nhb.gov.sg/stars/public/

II7 The Prime Minister, Mr. Lee Kuan Yew's address at the Parliamentary Luncheon, Wellington, 4 April I975, lky/1975/lky0404.doc, http: //stars.nhb.gov.sg/stars/public/

II8 Speech by the Prime Minister in reply to H.E. Field Marshal Thanom Kittikachorn, Prime Minister of Thailand at a dinner, 8 January I973, lky/ig63/lkyoıo8b.doc, http: //stars.nhb.gov.sg/stars/public/

II9 Speech by Mr. Lee Kuan Yew, Prime Minister, at a dinner in honour of his Excellency, Mr. Dzemal Bijedic, President of the Federal Executive Council, Socialist Federal Republic of Yogoslavia, I7 March 1973.

I20 Excerpts of address by Singapore's Prime Minister, Mr. Lee Kuan Yew, on the Change in Great Power Relations at the Commonwealth meeting in Ottawa, 3 August I973, lky/1973/lkyo8o3.doc, http: //stars.nhb.gov.sg/stars/public/

I2I Speech by Mr. Lee Kuan Yew, Prime Minister, at a dinner in honour of his Excellency, Mr. Dzemal Bijedic, President of the Federal Executive Council, Socialist Federal Republic of Yogoslavia, I7 March I973, lky/i973/lkyo3I7a.doc, http: //stars.nhb.gov. $\mathrm{sg} /$ stars/public/

I22 Jacob Blaustein Lectures: Lecture: Southeast Asian View of the New World Power Balance in the Making, lky/1973/lkyo330.doc; Lecture II: Decolonisation and the Non-Economic Factors of Development in New Countries in Southeast Asia, lky/I973/lkyo4or. doc; Lecture III: Security and Stability Essential for Development of New Countries in Southeast Asia, lky/1973/lkyo402.doc, http: //stars.nhb.gov.sg/stars/public/ Lee delivered the $8^{\text {th }}$ in the series of Jacob Blaustein lectures on international relations. 
I23 Excerpts of address by Singapore's Prime Minister, Mr. Lee Kuan Yew, on the Change in Great Power Relations at the Commonwealth meeting in Ottawa, 3 August I973, lky/ı973/lkyo803.doc, http: //stars.nhb.gov.sg/stars/public/

I24 The Prime Minister's Opening Address at the Conference on Southeast Asian Security, 3I May I974, lkyi974lkyo53I.doc, http: //stars.nhb.gov.sg/stars/public/

I25 Excerpts of speech by Mr. Lee Kuan Yew at the Commonwealth Heads of Government, Kingston, 30 April I975, lky/ı975/lkyo430.doc. http: //stars.nhb.gov.sg/stars/ public/; Lee gave many interviews on the fall of Vietnam and its implications for Southeast Asia at Jamaica, and also after the Commonwealth Heads of Government meeting, see: Some views expressed by the Prime Minister Lee Kuan Yew when interviewed by Barry Jordan of New Zealand Television and David Cox of London Weekend Television, Kingston, early May I975, lkyi975lkyo5ob.doc, http: //stars.nhb. gov.sg/stars/public/; Transcript of an interview with Prime Minister Lee Kuan Yew by Barry Jordan of New Zealand TV, Kingston, Jamaica, May I975, lky/I975/lkyo5og. doc, http: //stars.nhb.gov.sg/stars/public/; Transcript of a television interview with Prime Minister Lee Kuan Yew by Ken Begg and Paul Kelly of the Australian Broadcasting Commission and Warwick Blood of "Channel ıo", Australia, Kingston, Jamaica, May I975, lky/ı975/lky050e.doc, http: //stars.nhb.gov.sg/stars/public/; Transcript of interview with the Prime Minister by Robin day of the BBC for "News Day", a BBC programme, Kingston, Jamaica, lkyi975lkyo5oc.doc, http: //stars.nhb.gov.sg/stars/ public/; Transcript of a press conference held by Prime Minister Lee Kuan Yew at the end of the Commonwealth Conference, Kingston, Jamaica, first week of May I975, lky/I975/lkyo5oa.doc, http://stars.nhb.gov.sg/stars/public/; Mr. Lee Kuan Yew's speech at the Commonwealth Heads of Government meeting, Kingston, 5 May I975, lky/I975/lky0505.doc, http: //stars.nhb.gov.sg/stars/public/; Face the Nation (produced by CBS News, Washington D.C, II May I975, lky/ı975/lkyo5II.doc, http: //stars. nhb.gov.sg/stars/public/: Excerpts of an interview with the Prime Minister, Mr. Lee Kuan Yew, by Adrian Porter, BBC Southeast Asia correspondent, I4 September I976, lky/ı976/lkyo9I4.doc, http: //stars.nhb.gov.sg/stars/public/; Transcript of Question and Answer session following Prime Minister's address at the Asia Society dinner, New York Hilton, I2 May I975, lky/I975/lkyo5ı2b.doc, http: //stars.nhb.gov.sg/stars/ public/; Address by Mr. Lee Kuan Yew, Prime Minister of Singapore, at the Asia Society Dinner, New York Hilton, I2 May I975, lky/ı975/lkyo5I2a.doc, http: //stars.nhb.gov. sg/stars/public/: Transcript of press conference given by Prime Minister Lee Kuan Yew, Tokyo, 22 May I975, lky/I975/lkyo522a.doc, http: //stars.nhb.gov.sg/stars/public/; Transcript of an interview with Prime Minister Lee Kuan yew by Chuo Koron, a leading Japanese monthly journal of philosophy and politics, Tokyo, 22 May I975, lky/ı975/lkyo522b.doc, http: //stars.nhb.gov.sg/stars/public/ 



\title{
13 A Brief History of the Hub: Navigating between 'Clobal' and 'Asian' in Singapore's Knowledge Economy Discourse
}

\author{
Leong Yew
}

\section{Singapore: a knowledge economy?}

Since the I990s, the concept of a 'knowledge economy' has been used by the Singapore government as a way of rationalising and anticipating the next phase of the country's development. Economically, it was intended to mark the transition from one phase of production - a labour and materialintensive industrial economy - to one based on research and knowledge production. By doing so, the government hoped that it would further differentiate Singapore from the other countries of the region, which were experiencing the Asian Economic Miracle and thus becoming economically competitive. The knowledge economy had grander implications as well, particularly in terms of cultural processes. Here it can be noted that under the knowledge economy a range of factors - physical, social and ethnic landscapes, business models and practices, national identity, Singaporeans, and the concepts of foreign, local and cosmopolitan - all became reconfigured for life in the 2Ist century. Thus various arms of the government leapt into action, churning out policy directives on industry, labour, information and communications technology (ICT) and media that would take Singapore to the next level. On the ground, the government courted investors, partners and talent with generous grants and research infrastructure, cleaned up its intellectual property regimes, and emphasised a new model of Singaporean-as-entrepreneur.

From the policy perspective, Singapore's knowledge economy extended and adapted a pre-existing narrative of progressivist developmentalism. Like many of its other national campaigns, the knowledge economy has been framed by a logic of technical-bureaucratic rationality. According to Singapore's political leaders, the knowledge economy is seen in terms of continued national economic growth, competition, and identifying areas of comparative advantage, particularly in the light of increasing competition unleashed by the wake of the Asian Economic Miracle. The knowledge economy is therefore predicated on this overused aphorism: Singapore, unlike its neighbours, has no 
natural resources, only its people and an advantageous geographical location. Fortunately because of the ability of its political leadership, investment and developmental assistance from First World countries, and the calibre of its human resource, it has been able to prosper without natural resources or an economic hinterland. Thus it is possible to see how the knowledge economy has been interpreted as a natural next step in Singapore's development. Since the main requirement of the knowledge economy is knowledge work rather than large-scale, labourintensive industrial production, Singapore's constant global connectivities and highly-skilled and pliable workforce mean that there are few obstacles in the way of this economic transition.

It is on this basis that I wish to contextualise the Singaporean knowledge economy on the basis of various tensions that are ontological and geographical in nature. In abstract terms, Singapore's conception of the knowledge economy raises a similar issue to those faced by OECD countries. On the one hand, there is little clarity or consensus about what actually constitutes a knowledge economy (Kenway, Bullen, Fahey, \& Robb 2006), while on other there is a tacit sense of how politically it is intended as a form of teleological developmentalist progression, identifying a new post-industrial endpoint that will continue to separate First World societies from their industrialising counterparts in the Third World.

In this sense, Singapore recognises the knowledge economy as an evolution from the post-industrial or information society identified by Peter Drucker in the late I950s and Daniel Bell in the I970s, which emphasises new ways in which value is assigned to commodities. Under the knowledge economy, it is believed that new forms of commodities such as complex electronic equipment, software, pharmaceuticals, film, books and music will displace traditional commodities because most of their value is derived from knowledge as a factor of their production rather than the usual labour and raw materials. This functional invariance is problematic because it reproduces Singapore as merely a node in the wider network of knowledge economies. In order to differentiate itself, Singapore makes use of a culturalist geography, a sense of its own physical location, combined with a reinvented imagination of its cultural identity. But this too has its own preferences between the 'global' and 'Asian'. As has been discussed in this volume, much of Singapore's history has been framed through a continuous narrative of the island's connectivities with the wider world, attributing Singapore's success to its role as a port city and the extent to which capital, cultural and demographic flows have been facilitated. In this way, Singapore's knowledge economy builds on these flows, in which the local and the global enable the circulation of knowledge commodities, capital and resources. 
However, Singapore's relationship with the wider world has tended to be seen in more ambivalent terms, particular in a period of time in which Singaporean narratives of progressivism have come to be rearticulated through Asian culturalism. If the global homogenises Singapore's knowledge economy, Asia as an abstract region is intended to be the point of differentiation. Thus through Asian culturalism, Singapore's leaders sought to convert its knowledge economy on various levels. Because of the state's geographical and cultural proximity to Asia, it has attempted to marry physical convenience with its role as a knowledge comprador. Its location meant that knowledge workers and companies had easy access to regional subjects and local capital, while its new culturalism suggested that Singapore possessed the regional knowledge on the one hand and on the other the skills to interface with the global knowledge network. But this creates more intellectual tensions than it resolves. For if the state embraces globalism as the basis for its continued social and economic development, the notion of Asia, despite state attempts to naturalise it in the imagination of its people, merely becomes peripheral. But it may also be argued that this makes the rationalisation of the knowledge economy highly disjunctive, depending on who the discourse targets. To global investors and partners, Asia is merely subordinated to global capital, but to its own people the Singapore government has attempted to Asianise the knowledge economy in such a way that its knowledge workers become accustomed to accepting the Asian 'content' as indigenously their own.

To the state, the tensions between the global and the Asian are not incommensurate and the idea of Singapore as a 'hub' - a redesigned nomenclature for the historical port city - has been offered as a resolution. But this resolution has not been entirely satisfactory because the hub is not spatially neutral, but rather invested with contradictory and dissonant meanings. In some instances, the Singaporean hub is seen to be global and at other times regional. And on many other occasions, the hub is seldom seen without a disciplinary prefix. It is interchangeably associated with an endless list of activities: trading, sea and air transportation, communications, media, IT, educational and so on.

What I aim to do in this chapter is to reposition the 'hub' as an explanation for the disjunctures between the global and the Asian in Singapore's knowledge economy discourse. To do so I provide a narrative of Singapore's knowledge economy in relation to these spatial concepts and ask what is at stake as the state attempts to fashion itself as an Asian knowledge expert. I begin with Asian knowledge as it is traditionally understood (as area studies), but then move on to show how this knowledge has also taken on a more popular or 'soft' form, in which knowledge products such as broadcast journalism and financial services also lay claim to Asian expertise. This expertise is then contextualised under the new mission of Singapore's universities and how all disciplines, regardless of 
their orientation toward scientific universality, must now be abstracted for their 'Asian' value. It is on this premise that an alternative reading of Singapore's knowledge hub is needed and this compels one to think about a type of Asian knowledge production that has a greater amount of tension and ambivalence towards historicism that has often been the case with the life-process of capital.

\section{The knowledge economy and the global-Asia nexus}

Some of the earliest public articulations of the knowledge economy by Singapore government officials were made during the early I990s, but with little clarity about what it meant then. ${ }^{\mathrm{I}}$ In some instances they recognised that technology was having a substantial impact on its citizen's work and recreation, and more specifically the way it affected communications and information acquisition. In I99I the National Computer Board launched the third phase of a longer-running nationwide computerisation strategy that began ten years earlier. This third phase, which became known as the IT2000 master plan, sought to transform Singapore into the "intelligent island", as both a way of signalling new forms of competitive advantage as well as improving Singaporeans' quality of life. But more significantly it coincided with a period in which technology was no longer merely a facilitator of other social and economic activities but was a generator of wealth on its own terms. Thus, on the one hand it coincided with the rise of the Internet, but on the other hand, it also produced the dot com boom, which at that time was virtually synonymous with the 'new economy'.

By I999, after having witnessed the Asian Financial Crisis two years earlier, the knowledge economy was to receive much clearer introspection, while the differing perspectives of the concept offered by different ministries and government agencies suggested that the knowledge economy had become a more totalising organising force in Singaporean society. A form of millenarianism took hold of government planning efforts, and various government initiatives were launched to prepare the various aspects of Singaporean society for life in the 2Ist century. Most of these had economic dimensions such as "Industry 2I" and "Manpower 2I", which were to join other plans such as "InfoComm 2I", "Technopreneurship $2 \mathrm{I}$ ", and "Media 2I" that were to materialise in the following four years. But most significantly, this year would best be remembered for the release of "Singapore 2I", a blueprint positing a set of national ideals that would take the country into the 2ist century. In justifying the need to redesign these ideals, the official Singapore 2I publication characterises the future that world citizens will need to confront, with the knowledge economy fronting a list that also included the 'borderless world' and 
demographic changes. On a much smaller scale, but no less important, was the EDB pamphlet, "A Knowledge-based Economy". As the government body in charge of industrial development, improving the business environment and attracting foreign investment, the EDB attempted to sell Singapore's knowledge economy to prospective international partners and investors through a particular narrative. Here the EDB identifies the 'twin engines' of the knowledge economy as manufacturing and service industries that emphasise technology and innovation. Most of the document deals with the clusters proposed by Industry 21: electronics, petroleum and petrochemicals, life sciences, engineering, education, healthcare, logistics, and communications and media, while asserting how Singapore is positioned to become a global or regional hub in each of these.

Also in that year there were a number of government speeches about the knowledge economy. Of particular interest was a lecture by thenDeputy Prime Minister Tony Tan entitled "The Singapore Economy in the 2ist Century". In his speech, Tan stressed that the knowledge economy could be explained as one of "increasing weightlessness". By 'weightlessness', Tan was essentially stating that the economic value of products was rapidly becoming inversely proportional to the amount of materials used in manufacture. In other words, things such as computer software, information, and financial transactions tended towards weightlessness because they were "infinitely expansible", consisting of very little material mass and therefore delivering high value when distributed.

Within the first few years of the new millennium, some of the promises of the knowledge economy were to be eviscerated almost as soon as they were offered. IT, for instance, was noted to be the knowledge economy's driving force (see Tan 1998) and the InfoComm 2I initiative anticipated an IT sector teeming with 250,000 workers by 2010 . However, with the bursting of the dot com bubble in March 2000, Singapore's government planners were compelled to change the focus of the knowledge economy. Biotechnology and life sciences became increasingly recognised as the main drivers of the new economy and the technopreneur became reinscribed as the generic 'risk-taking entrepreneur', while IT returned to its secondary place as the facilitator for the various hubs in the knowledge economy. ${ }^{2}$

With Singapore experiencing an economic downturn, the Economic Review Committee reports that were released between 2002 and 2003 could not, therefore, have been timelier. In presenting a wide-ranging set of recommendations for restructuring the Singapore economy and identifying new growth areas, it restated the fundamentals underpinning the knowledge economy while also introducing a number of graduated shifts. In broad terms it re-emphasised Singapore's role as a node in the global 
economy, the importance of creativity and entrepreneurialism, and the need for a diversified economy that integrated multinational companies, start-ups, and traditional businesses to produce innovative products and services (Singapore Economic Review Committee 2003: 5-7). But subtly, some other ideas were either introduced or accentuated. The committee now gave a firm recommendation for developing creative industries and providing educational services to students, mainly from Asia. From 2005 onwards, overt public references to the 'knowledge economy' by government officials became rarer, even as some new government initiatives were inaugurated. The IDA, for example, cycled through a few more ICT plans. In 2003, it launched the "Connected Singapore" plan, which replaced InfoComm 2I, and then again in 2006 the "Intelligent Nation 20I5" (iN2OI5) master plan sought to "navigate Singapore's exhilarating transition into a global city, universally recognised as an enviable synthesis of technology, infrastructure, enterprise and manpower" (Singapore InfoComm Development Authority 2008). Also within the realm of 'creative industries', interactive and digital media surfaced as a key area to develop and exploit.

Considering these developments, how does one locate or conceptualise the global and the Asian in Singapore's knowledge economy discourse? This is a curious proposition, because Singapore's strategy of marketing itself to potential international collaborators and knowledgeworker recruits has rested on the geographical and cultural advantages of being located in Asia and having a local workforce that is ethnically Asian (and therefore more linguistically and culturally conversant with the region) (Sidhu 2006). But in the public officials' attempts to communicate with different audiences, such as its citizens/workforce or international partners, or to identify various plans of action, the various geographies involved have been presented in more contradicting or incommensurable ways. In order to rationalise the widespread societal change in transitioning Singapore from a post-industrial society into an 'Asian' knowledge economy, Asia has been flexibly represented as an entity Singapore should differentiate itself from, as an economic competitor, while also embracing it as a place for Singaporeans to invest in or as an entity collectively cautiously venturing into the knowledge economy (see Chen 200I).

Let me illustrate this by referring to two disjunctive neologisms adopted by former Prime Minister Goh Chok Tong. The first is the geographically based "Boston of the East", which Goh introduced in I996 as a way of providing the Singaporean knowledge economy with an identity. In this instance, Goh was challenging Singapore's two universities (at that time) to become the Harvard and MIT of Asia, by attracting the best students from Asia and beyond (Chua I996). In 2000 Boston was once again used as a model, but now given more depth by 
Teo Chee Hean as not just a place occupied by two of America's top universities but by "over 200 universities, colleges, research institutes and thousands of companies". The geography depicted by the Minister for Education was intended to suggest that Singapore should adopt Boston's industrial synergies:

It is a focal point of creative energy, a hive of intellectual, research, commercial and social activity. We want to create an oasis of talent in Singapore: a knowledge hub, an 'ideas-exchange', a confluence of people and idea streams, an incubator for inspiration. (Teo 2000)

Implicitly, however, the "Boston of the East" is a transplantation of a foreign model and its novelty is precisely something that does not exist in the 'East'. So in order for a construct such as this to work, the East needed to be peripheralised - structured as less advanced - thus allowing for Singapore to be differentiated from the 'East'.

In the year following Teo's clarification, Goh presented another vision of Asia relevant to the Singapore knowledge economy that also intertwined Asia with the world. This came in his 200I National Day Rally speech in which he urged Singaporeans to expand the boundaries of their hinterland. Southeast Asia, he implied, was the hinterland of the past. Now Singaporeans needed to think in terms of flight durations, and, by conceiving a seven-hour flight radius, 'greater' Asia was within easy reach:

Within a 7 -hour flight radius of Singapore live 2.8 billion people, with hundreds of millions in the middle income group. We have only ourselves to blame if we do not fully exploit these opportunities. We should regard all the countries and cities which are within 7 hours of flying time from Singapore as our hinterland. (Goh 200I)

Naturally, China and India were included in Goh's geography and his pervasive logic was clearly one of instrumental rationalism. Yet in this geography two themes co-existed: the importance of the Asian hinterland to Singapore's economy and the unmentioned but assumed centrality of Singapore in this configuration.

Goh's 'seven-hour hinterland' therefore uses the idea of the 'hub' as a way of locating Singapore's relationship within the global and the Asian. While he was addressing a local audience, his implied positioning of Singapore at the centre of this (imagined) geography became a useful way to pitch Singapore's competitive advantage to investors, partners, and foreign talent. Two of Singapore's global interfaces: A*STAR, the agency that oversees high-level research in the country and the EDB have 
used the "seven-hour geography" as a way of elevating Singapore's hub status in various areas of research and industrial strength. For example, former EDB head, Ko Kheng Hwa explains it as "the regional gateway for global companies, and the global gateway for regional companies" (2003). But just as the "seven-hour hinterland" is constituted by simultaneously embracing Asia and centring Singapore, the idea of the hub also reveals the tensions between global and Asian regional scales. Overtly the state intends the hub to be a place that mediates and regulates flows of different values - human, capital, financial, plus commodities, information and transportation - between Asia and the world.

The hub is seldom used unmodified and it is often prefixed by adjectives such as 'global' and 'Asian' or by the evergreen 'world class' and then followed by a particular industrial cluster such as biotechnology, life sciences, education, and so on. However, how the global hub might be different from the Asian hub is not always clear. Is a global hub synonymous with the Asian hub? Or does the latter suggest a specific node within the Asian region? The EDB pamphlet, for example, claims that Singapore aspires to be a world class or global hub in electronics, education and healthcare but an Asian hub in logistics, communications and media (Singapore Economic Development Board I999). There is no clarity here if the EDB is being realistic about what the various sectors are capable of achieving or if it is intimating that specific sectors strictly cover certain geographical scales. But by extension, Singapore's obsession for excellence has also led to a geographical hierarchy of superlatives, thus global hub or Asian hub is used depending on where the benchmarking is better.

\section{Towards an Asian knowledge hub}

In Singapore the language of modernity and progress has often been deployed as a way in which certain national pursuits are accorded economic value, compartmentalised and prioritised over others, which then leads to functional differences in knowledge. Some forms of knowledge are thus deemed to be essential for economic development and industrialisation, while others relate more to national development (e.g. housing, healthcare and education, national cultural identity, and foreign policy/national security). In this way, the science, technology and professional fields such as law, medicine, and commerce have traditionally been valorised over other forms of knowledge or disciplines, such as the humanities and social sciences.

The story that I wish to tell now is about the transformation of such attitudes to knowledge into disjunctive formations that are valued precisely because they are not universal but because they demonstrate Asian 
regional expertise. This change attempts to position Singapore as an intellectual comprador, selling its Asian expertise (which also includes science and technology) to the global knowledge economy. This story begins with the formalisation of Singaporean Southeast Asian studies in I968 with the founding of the Institute of Southeast Asian Studies (ISEAS). According to ISEAS's narrative, Southeast Asian studies did not previously exist (Institute of Southeast Asian Studies I998). In its earlier incarnation, Southeast Asian studies in Singapore were patchy and 'diffuse' with the only sustained activity within the History Department at the University of Singapore ${ }^{3}$ (Institute of Southeast Asian Studies I998: 6-7). The Parliamentary Act that created ISEAS was therefore described as ambitious. It was a response to regional political realities such as the founding of ASEAN and the many anxieties of a region confronting problems of modernisation, development, and conflict. It also aimed to distinguish itself from the Southeast Asian Studies taught in Western countries by claiming to be the first of its kind within the region itself; it was independent and not affiliated with any university, it encouraged its researchers to focus on places other than their home countries or on the region as a whole, and it sought to foster collaboration, both from within and outside the region (Institute of Southeast Asian Studies I998: 7-8).

The role of the state in directing academic knowledge production can also be seen in the less successful Institute of East Asian Philosophy (IEAP), which was established in I983. As a unit within the National University of Singapore (NUS), the idea of the IEAP was to "put Singapore on the map as a centre for research into Confucianism as applied philosophy suitable for the modern age" (Lee 2008: 540-I). But IEAP's inauguration also coincided with the arrival of a 'culturalist' phase of Singapore's ethnic management, which saw the advent of religious knowledge and moral education in its high school curriculum. Thus the production of knowledge about East Asian philosophies was implicitly linked to the state's attempts to naturalise, validate, and ironically reunite (Chinese) Singaporeans with a presumed moral and philosophical code. The failure of the Confucianism project in Singapore due to suspicions by other ethnic groups that the country was Sinicising has been fairly well documented (Chua I995; Hong \& Huang 2008). But as Edwin Lee reminds, this development also meant that the IEAP lost much of its legitimacy as well (2008: 542).

Both cases - ISEAS and IEAP - demonstrated that in order for their respective forms of regional knowledge production to be 'useful', they needed to resonate with a national cause. By the late I990s, however, what constituted national utility became broader and more complex. For example, the deprioritisation of government support of the arts in the I96os, because it was deemed a luxury item suddenly came to the forefront in the Renaissance City project. Various disciplines in the humanities and 
social sciences that would otherwise have been considered esoteric and valueless became increasingly relevant. For example, since its founding ISEAS' prime interest in regional and political affairs was complemented by economic studies, social, cultural and gender studies. But the transformation of the IEAP into the East Asian Institute (EAI) in I997 under the wing of the acclaimed scholar Wang Gungwu offers a key insight into how knowledge and value have moved in tandem. In George Yeo's address at the official opening of the institute, the justification of the EAI was understandably tied to the rise of the East Asian economies and the urgency of securing Singapore's place within them (see also Lee 2002):

The economies of the countries of East Asia are developing so rapidly that we can expect the East Asian region to account for some $40-50 \%$ of the world's GNP some time in the middle of the next century. East Asia is therefore an enormous reality for all of us in Singapore. It is crucial that our political, intellectual, cultural and emotional perspectives take into account the economic trends transforming Asia and the world. (Yeo 1997)

In a sense the EAI allowed Yeo to rescue the IEAP from an ignominious fate; so, instead of the messiness of its Confucianist projects, the IEAP now became an institution that foresaw the rise and future importance of China. Notwithstanding the Asian financial crisis, the rise of the Asian economies, particularly those of China and India, was to be directly linked to the boom in the Asian knowledge industry. Coming on the heels of the EAI were a number of other Asian Studies research institutes that were launched in the following decade, especially the Asian Research Institute (ARI) and the Institute of South Asian Studies (ISAS). Such as the EAI, ARI and ISAS became university-level entities rather than belonging to a university faculty or school and one of the main justifications for their existence was also that of national instrumental rationalism. By then, the notion of 'changing Asia' or 'Asia in transformation' had become a welldeployed state narrative, which was again used to frame ARI and ISAS (see Goh 2005; Shanmugaratnam 2006; Teo 2003). In the case of ARI it represented a changed national interest in which the whole of Asia, rather than discrete parts of Southeast or Northeast Asia, needed systematic academic inquiry from the perspective of research programmes in population, religion, migration, and cultural studies. And for ISAS, India's rise in the global economy was seen to have strategic implications, compelling scholars to 'reconceptualise East Asia' by researching South Asia's interconnections with the broader Asian region and its neighbouring sub-regions (Goh 2005).

The decade after 1997 should be noted for other consequences to the nature of Asian area expertise. First, apart from Asian research performing 
an indirect role in boosting Singapore's regional economic performance by providing knowledge, it also came to be involved in directly generating revenue. As part of the "Global Schoolhouse" strategy, the raising of the profile of Asian research was also intended as a way of attracting graduate students from overseas. Since EAI, ARI, and ISAS were university bodies, student contact and collaboration with their researchers were facilitated. Furthermore, the three main universities started using their other forms of Asian expertise to attract students. For example, in order to compete for students/clients, the NUS' Lee Kuan Yew School of Public Policy, the MBA programme at the Singapore Management University, and the 'elite' Nanyang Fellows Programme at the Nanyang Technological University's business school all adopted the same narrative of an unstoppable Asia on the rise, which created both opportunities and problems. These required the leadership which these programmes were well-placed to provide (Lee Kuan Yew School of Public Policy; Nanyang Technological University; Singapore Management University).

Second, academics and researchers were no longer the sole purveyors of Asian expertise and in effect Singapore's pursuit of the knowledge economy also led to the popularisation and softening of Asian knowledge. Thus alongside the universities and research institutes, both public and private bodies such as the National Library, the National Heritage Board, and a gamut of private corporations also saw their mission as providing and producing Asian knowledge. For example, private corporations' provision of Asian expertise demonstrate some of the most interesting changes to how Asian knowledge is produced and distributed, because it distils state-led ideas about how the nation can differentiate itself in the competitive global economy. In I999 Singapore's Mediacorp 4 launched Channel NewsAsia (CNA), an all news and current affairs TV station that was first targeted at local and subsequently (in 2000) regional professionals, managers, entrepreneurs and businessmen. Since the channel had to compete with established players such as CNN and BBC, it sought to differentiate itself by providing regional and international news with an 'Asian perspective'. Similar to research institutes, CNA legitimises its knowledge production through the credentials of its journalists, who are mostly residents of the places they cover. While television news stations can claim expertise because their main business is information, the ability for financial institutions to be area experts appears somewhat dubious; after all their main activity is to provide financial services. Yet Singapore's DBS Bank's Asianisation from 2005 onwards is a curious development. This Asianisation was the result of a rebranding exercise, which saw DBS Bank reconceiving its clientele while also undergoing an intense phase of corporate culturalisation. This was triggered off by the liberalisation of Singapore's financial services sector, which would see the entry of large multinational banks, and DBS Bank's realisation that 
the only way to compete was by specialisation, which in this case (such as the many discussed so far) was to present itself as an expert in the Asian financial scene:

We live and breathe Asia. Our competitive advantage lies in our understanding Asia's cultural nuances, and in our ability to capitalise on this insight to help our customers in Asia deal with their most important needs.

With foresight and determination we built expertise over the years in capital markets, treasury, and wealth management. Today, we are able to leverage these capabilities in connecting our clients in Asia with our extensive distribution to traditional as well as 'New Asian' investors. (Tai 2006: I5)

These two transformations - the extension of the Asian area expertise beyond academic Asian Studies and its incorporation into the logic of the global schoolhouse - were accompanied by a third development that was to occur from the middle of the decade onwards. While the language of economic rationalism had been mainly used to justify state support for the various research programmes under the knowledge economy, Singapore's public officials were beginning to view them in ways other than generating revenue or new forms of economic value. The knowledge economy, its corresponding effects on Singapore's landscapes, demography, society, and its diverse forms of research cultures and networks, was now valued abstractly for its broad role in national revitalisation. Thus, knowledge areas that cannot directly be used for financial profit become resignified on other terms. For instance, the Asian Civilisations Museum has often been interwoven into Singapore's Renaissance City project, and in some ways also adds to the marketability of the country as a tourist destination. But the idea of national revitalisation through the knowledge economy is also a major ACM narrative. Tommy Koh's opening address of the Empress Place branch of the ACM is quite telling, in this regard. In a short exegesis, the speech rearticulates the value of architectural heritage and conservation, before declaring the museum's role in national learning and cultural reconnection. But most notably, the museum was also seen to spatially represent the knowledge economy, which, borrowing from George Yeo, was to "help us to plug into an international cultural network" while also displaying 'synergy' among the landmarks in the changing civic district area (Koh 2003). In this context, Shanmugaratnam's speech at ARI's fifth anniversary is also quite significant for its portrayal of a maturing knowledge economy discourse, emphasising that different nodes in the economy should be considered differently in terms of their impact. In the case of ARI, it was to be seen as "global excellence 
in research", i.e. the way its research output is received and recognised by scholars elsewhere in the world. Additionally, ARI was seen in terms of the 'balance' it would bring to the wider scope of knowledge production in the NUS (Shanmugaratnam 2006).

\section{Global-Asian knowledge and the 'NUS Difference'}

Do the various positions adopted by the state and society about the knowledge economy represent a unique Singaporean or Asian appropriation/ reformulation of it? And if Singapore's status as a knowledge hub vacillates between the global and the Asian, how should we make sense of it? I argue that a response to these questions lies in the way the agency of the knowledge worker is situated in relation to capital. For this I turn to Dipesh Chakrabarty's reading of Marx. In his essay on 'Two Histories of Capital' Chakrabarty reminds us that Marx conceptualised two types of histories: the first are "histories "posited by capital" and the second are "histories that do not belong to capital's 'life process", which he labels respectively as history I and history 2 (2000: 50 ). In the first case history is complicit with the logic of capitalism, allowing for the reproduction of capital, and is "the universal and necessary history we associate with capital [and] it forms the backbone of the usual narratives of transition to the capitalist mode of production" (2000: 63). History 2, however, should be considered disjunctive rather than oppositional to history I. While history 2 also lays claim to the same 'antecedents' of capital, as does history I, its use of these antecedents, however, perform an opposing function, which is to reconfigure or appropriate them outside the context of capital (2000: 63-4). Surprisingly, Marx identifies two of these antecedents: money and commodities. It is easy to see how they fit into the life process of capital and therefore as necessary elements of history I. But Marx also suggests that money and commodity can have an existence outside the history of capital, and this is where the various characteristics of history $2 \mathrm{~s}$ arise. Chakrabarty writes:

Marx thus writes into the intimate space of capital an element of deep uncertainty. Capital has to encounter in the reproduction of its own life process relationships that present it with double possibilities. These relations could be central to capital's self-reproduction, and yet it is also possible for them to be oriented to structures that do not contribute to such reproduction. History $2 \mathrm{~s}$ are thus not pasts separate from capital; they inhere in capital and yet interrupt and punctuate the run of capital's own logic. (2000: 64)

By relating history I with the innumerable variations of history 2, it becomes possible to create a "politics of human belonging and diversity" 
by providing the basis on which "multiple ways of being human" could be related to a singular "global logic of capital" (2000: 67).

Let me now attempt to reconnect these various interpretations of knowledge capitalism to the way the global and the Asian are configured to support Singapore's knowledge economy and how its knowledge workers can inhabit different value systems and also participate in the production of "history I" and "history $2 \mathrm{~s}$ ". In order to do this I shall examine Singapore's higher education sector and its attempts to differentiate itself in the global knowledge economy - in particular the activities of the National University of Singapore (NUS). As argued earlier, Singapore's attempt to differentiate itself by identifying itself as the global knowledge hub in Asia does not mean that it is defining an alternate mode of production. On the contrary, all of Singapore's mainstream history is in effect the story of different configurations of capitalism playing themselves out, transforming and sublating Singapore into the logic of capital. The type of differences we are witnessing at this point are merely the contradictions and disjunctures that constitute late capitalism (Appadurai I990) and in this way, differentiation is indeed the 'becoming' that Chakrabarty associates with history I. So, considering capitalism's logic in Singapore, all of its subjects (both individual and corporate) contribute to its reproduction. The higher education sector is no exception. According to the narrative through "history I", Singapore's universities were, before the advent of the knowledge economy discourse, largely teaching and degree-granting institutions. However, with the articulation of Goh Chok Tong's "Boston of the East" vision, its subsequent refinement by Teo Chee Hean, and the launching of the global schoolhouse initiative in 2003, the higher education landscape was to undergo a tremendous transformation. The universities had to take on a corporate model and underwent Americanisation. ${ }^{5}$ Students became customers and were presented with a more broadly based and interdisciplinary curriculum (compared with the former Britishinspired system). The faculty were subjected to more stringent performance assessments, including competition from imported foreign staff and were placed within an American-style rank, promotion, and tenure system. As an institution the Singaporean university now needed to become a centre of excellence, a purveyor of educational services to a booming regional market, and a research entity. In short the universities were no longer organically autonomous but had to be plugged into a network that included the private commercial sector, other research institutes, other universities in the world and the government.

Collectively, as the higher education sector - along with the other constituents of the Singapore knowledge economy - faced the anxiety of universalisation and standardisation, competitively there was structurally little to distinguish Singapore from other knowledge economies. ${ }^{6}$ In the 
broader language of the knowledge economy, the ironic juxtaposition of the global and the Asian gave Singapore a competitive advantage. To a large degree, NUS' transformation during the first decade of the 2Ist century heavily resonated with Singapore's broader strategies of differentiation. There are two tangents to this narrative, which coincided roughly with the tenures of two successive university presidents. Between 2000 and 2008, the globalisation of NUS played the major focus, while its Asian emphasis was more ambivalently parcelled out to various departments and units. For example, the Faculty of Arts and Social Sciences was identifying itself as an interdisciplinary expert in Asian Studies, while ARI and ISAS were formed. But this was to take place within the larger preoccupation with the 'global', a scale that was to fuel institutional development as well as a form of competitive benchmarking. Indeed, in 2002 the NUS changed its vision statement to "Towards a Global Knowledge Enterprise" and also gave its newsletter a name to reflect this purpose. But it is the series of university annual reports that articulate its sense of the global. During its centennial year, the 2005 annual report was entitled, "Singapore's Global University". Asia was not mentioned much, except when contextualising NUS' ranking against other universities. In most cases, the narrative describes how NUS has attempted to globalise, how it needs to foster global connections, and the urgency of establishing itself as a 'global brand' (National University of Singapore 2005). The subsequent annual reports similarly continued to emphasise the role of globalisation in NUS. For instance, in the 2007 issue, entitled "The NUS Difference" the anxiety was one of competitiveness (National University of Singapore 2007). This was the year Singaporean universities were formally detached from the Ministry of Education and became non-profit organisations. So the narrative was one of making NUS compete with other global institutions that had a longer history and bigger reputation.

In 2009 , with the installation of a new president, 'Asia' took on a more corporate-wide role in the identity of the University. While Asia had previously been somewhat subordinated under the 'global', it was now the very entity that served to make NUS - and by imputation the rest of the Singaporean knowledge economy - unique among its competitors. To a certain extent, this change occurred because being 'global' was no longer sufficient, since this was the same theme adopted by other universities in the region and elsewhere. Once again, the trope of the hub came to the rescue:

The distinctiveness of being a leading global university centred in Asia opens perspectives and paves the way for the University to provide meaningful opportunities for students to gain international exposure while incorporating Asia-related contexts and perspectives. A new International Strategy was 
also developed to enhance efforts in international contributions and further elevate the University's position as the partner and university of choice in Asia for many of the world's best universities and students. Among other things, this strategy would provide increased opportunities for students to broaden their intellectual and personal outlook. (National University of Singapore 2008: 19)

Consequently a new vision was conceived. While still retaining the idea of becoming a "global knowledge enterprise", the NUS now also sought to be "a leading global university centred in Asia, influencing the future". However, unlike the more problematic articulations of Asian-centricity by Singapore government agencies such as the EDB, NUS' perspective seems to have been more logically worked out, representing a regionalisation of knowledge. The president, Tan Chor Chuan, felt that having a culture of excellence and a talented body of students and staff were no longer enough (Tan 2008). The University now had to further distinguish itself by centring itself in Asia. This was to be manifested in four areas: ensuring students developed "a strong appreciation of global issues, alongside perspectives from Asia"; recruiting worldclass faculty who specialise in "strategic academic areas" and who have Asian expertise; developing NUS as a "magnet for talent" and becoming the "preferred partner" for entities seeking partnerships in Asia; and becoming a thought-leader that articulates both global issues while "reflect[ing] Asian views and perspectives" (Tan 2008). This notion of Asian-centricity is a curious development because it is not easy to see how the particularity of Asian regional knowledge could be reconciled with the universality of other domains of knowledge such as science and technology. In other words it might be easy to see how Asian-centricity can influence the research agenda in the humanities and social sciences, but how would this affect disciplines such as physics, engineering, and chemistry that are more universally-applicable in nature? This problem has to an extent been addressed by government officials in that the problems confronting the Asian region have cultural, technical, and policy implications, requiring different forms of attention and methods of resolution. In promoting Biotechnology, for instance, the EDB has asserted that Asia has a different demography of medical problems, which places Singapore in easy reach of a unique body of research subjects as well as a different pharmaceutical market. In a similar way, Tan's vision of an Asian-centred university would call for identifying regional problems that require solutions from different disciplines, while also suggesting that new forms of knowledge might emerge as a result of its activities within Asia. Significantly, the university's commitment to Asia was then crystallised in the form of the 
'Global-Asia Institute'. While still a very new institution in which little research output has materialised, it sports the motto of "transcending boundaries of geography and knowledge", aiming to "take a holistic approach to the fundamental issues confronting Asia and the world" (National University of Singapore 2009).

This story of NUS' incorporation into the Singaporean discourse of the knowledge economy, its changing contentions with the global and the Asian, and its attempt to define regional 'thought-leadership' provides an interesting glimpse into the way transformations within the knowledge capitalism in Singapore both reproduce the state's wider economic strategy and how this in turn re-consolidates the logic of capitalism. This story is thus Chakrabarty's "history I", although it now deals more heavily with various attributes of late capitalism, such as the necessity for differentiation and how, for scholars such as Leo Ching, such differentiation is realised through the consumption and commoditisation of 'Asia' (Ching 2000). However, it must be noted that universities are also sites of critical self-reflection and, as such, they both reproduce the enveloping national discourse, while being capable of playing a more disjunctively resistant and subversive role. Thus universities also produce their fair share of "history $2 \mathrm{~s}$ ", and by disjunctive I am asserting a feature of these histories which for Chakrabarty "do not constitute a dialectical Other of the necessary logic of History I" (2000: 66) and are "not pasts that separate from capital... [but] they inhere in capital and yet interrupt and punctuate the run of capital's own logic" (2000: 64). To do this I shall now revisit Asian Studies in NUS, especially through ARI, and discuss how its emergence relates to history 2.

Typically, Asian Studies and ARI could be incorporated in history I, as knowledge becomes commoditised, as the university attempts to find new ways of abstracting value and as faculty are transformed into knowledge workers whose labour power is monitored under the new conditions of knowledge capitalism. Yet scholars can also possess multiple subjectivities, playing a role as knowledge capitalists in attempts to secure funding or publicise the impact and value of their research, while also simultaneously assuming the role of the scholar in which research output is virtually de-commercialised. I argue that the result of these multiple subjectivities is not a consciousness that exists outside of the logic of Singaporean capitalism or styles of critique that might be fashionable in Western academia. What materialises, therefore, is a form of ambivalence that vacillates between both positions. As an institution that attempts to identify its uniqueness as an Asian Studies institute and yet be global, ARI typifies this ambivalence.

In an earlier part of this chapter I presented the official narrative surrounding ARI's emergence. As a creation of the 2Ist century, its founders were undoubtedly aware of the many critiques of Asian Studies 
qua area studies, particularly in the way it originated in Western institutions. For example, Edward Said has famously intimated that contemporary area studies is a latent form of Orientalism (I978) and a lot of research work conducted in the West is to some degree Orientalist. Thus the anxiety at the inception of ARI, much like that of ISEAS, was that it should not be simply a replication of the Western institute of Asian Studies but had to uncover its unique niche. However, this process involves being both global and functional. During ARI's early days, its international board, comprising highly ranked academics from Asian and Western universities, was charged with this responsibility. As part of ARI's launch, for example, a 'Roundtable on Research Priorities for Asia' was held, which drew comments such as ARI needing to avoid the 'hyper-professionalism' in the US, but adopting a more interdisciplinary stance and emphasis on problems particular to the region (quoted and cited in Lindsay 2003: 2). In the following years, ARI realised that being Asian meant that it had to focus on various topical areas, so consequently the institute became divided into clusters on migration, the changing family, cultural studies, religion and globalisation, Southeast Asia-China interactions, and urban sustainability. These topical areas were to be the point around which both Asian and Western scholars could gravitate. This objective was mentioned in one of the ARI newsletters as follows:

Singapore is a great location to bring together Asian and global scholars, in the hope of correcting some of the imbalance in the way the world's ideas tend to be generated. We hope that regional scholars have a stronger voice, and scholars based elsewhere rethink some of their assumptions. (Reid 2004: 2)

So although the research agenda, foci, and the national/ethnic mix of ARI were to be different, the implicitly Western meta-language of Asian Studies appears to have been upheld, which again reflects more the multicultural anxieties that now dog Western centres of Asian studies rather than representing a problem unique to performing Asia research in Singapore. Thus, in order to counter the location of Singapore capitalism in ARI, one needs to juxtapose it against broader critiques of Asian Studies in the West.

Depending on the research interest and theoretical exposure, there will undoubtedly be different groups of scholars who will produce research work with varying sensitivities and disposition toward history I and history 2 within ARI and the rest of NUS as well. So far, what constitutes history 2 have been works that might be aware of Marxism or postcolonial theory, which also cannot entirely be divorced from the logic of global/Western capital. Interestingly this has left some reflections that 
articulate critical consciousness, but not necessarily a resolution of tension. For instance, ARI's new director Lily Kong, a cultural geographer, is no stranger to various critical social theories. But, apart from her academic work, she also has various senior NUS administrative appointments. So, on the one hand, she can be thought of as performing the role of Marx's 'manager' in reinforcing the various disciplinary mechanisms of the University's capital and labour power. But as an Asian scholar, other tensions could also arise. Writing in the ARI newsletter after her directorial appointment, she raises numerous problems related to creating a balance between global/Western academic concerns and ARI's identity as an Asian body.

On more than one occasion, Tony [Reid] had made it a point to promote the importance of offering to the world voices from Southeast Asia in particular. It is perhaps appropriate therefore that a child of Southeast Asia, located in a uniquely advantageous situation in Singapore, should succeed him in the quest to shape, influence, transform and balance the way the world understands Asia. Particularly, I bring to ARI an 'in-between' position - one which sees the possibilities of and need for critical engagements with Anglo-American scholarship, yet insistently advocating the need to stretch beyond that hegemony to develop Asian voices, perspectives and insights from Asia. (2008: 2)

The consciousness of hegemony is crucial here because critical scholars are often anxious about how different entities can at the same time appear to be liberating and hegemonic - the West, the global, capital, the Singaporean State, the workplace - and the question of emancipation then becomes difficult to factor in. There is also another element of history 2 that needs to be considered, and this is the inadvertent return of Asia as a geographical entity. Insofar as the postmodern, postsovereign capitalism is concerned, Asia has become increasingly deterritorialised and this is described through the experiences of the Asian Diasporas and human, cultural, and ideational flows. In this sense, Asian Studies is relevant and unique anywhere in the world, since Asia is no longer confined to the landmass between the Uralic-Altaic area and the Pacific Ocean. But, in attempting to become a Global hub in Asia, ARI (and Singapore) has had to once again reterritorialise Asia in order to sustain its very reason for existence. But how does this reterritorialisation take place? Is it a reinscription of an Orientalised Asia? Instead of returning to Said (in which the answer would be obvious), I would prefer to extend this to the notion of hospitality that is primary to ARI's cosmopolitan collection of scholars. In attempting to make itself 
different, ARI's attempt to attract researchers from Asia and the rest of the world is framed hospitably:

The Asia Research Institute seeks to address these needs from a uniquely advantageous situation in the heart of Southeast Asia, but equally enmeshed with China and India. It invites international scholars to reconsider their field from this Asian vantage point, and regional scholars to address a broader audience through this portal. (Asia Research Institute 2003)

And this is also echoed in the opening speech by Teo Chee Hean, which adorns and frames the opening pages of ARI's 2003-2004 annual report:

This Institute is designed to differentiate itself... by its open invitation to the best minds in social and cultural research to see the world from the vantage point of our dynamic region. (Asia Research Institute 2003)

Although one might claim that the notion of 'invitation' is purely a formality and incidental, its appearance is more suggestive of how ARI's (and Teo's) discourse asserts a reterritorialised and reconstructed Asia, this time centred in Singapore. This perspective comes from Derrida's critique of hospitality in which the construction of positions of 'host' and 'guests' are shifting and not intransigent. In effect, this takes place in the process of how the host self-constructs is intimately related to how a site in which hospitality is offered is given material reality (Derrida 2000). In the case of ARI, the site of hospitality is not Singapore per se. It is as much Asia as Singapore will allow it to be. As a result, the idea of locality in Asia becomes slippery and transposes easily onto each other. I close this section with a description of a Taiwanese scholar who, after working for many years in the US, narrates her relocation to ARI in Singapore as a homecoming and a return:

Personally, it is a home coming, back to Asia after a quarter of a century in North America... Returning to Asia now with a family is an emotional experience. Conversing in Mandarin or Hokkien with cab drivers and enjoying shaved ice and bak kut teh at the hawker stands bring back fond childhood memories that I am thrilled to share with my children. Professionally, I have returned at a time when exciting socioeconomic transformations are unfolding at an unprecedented speed in Asia, as a new world order is emerging in the economic, political, and cultural systems. As a family sociologist and a demographer, I have landed on a fertile ground for research on Asian families in transition. (Yeung 2009: 8) 


\section{Conclusion}

At this point in the 2Ist century, it seems reasonably clear that the knowledge economy - or the prospect of 'knowledge societies' - is linked with the inter-relationships of global capitalism, technology, transnationalism, cultural and human flows, and even millenarianism. Furthermore, the knowledge economy represents changes in the nature of commoditisation, production, and a blurring of the distinction between labour and capital (Coronil 2000: 364-8). Thus, the knowledge economy is just like any other process in what Fernando Coronil sees as increasing 'globalcentrism'. While there are many transformations in the sense of global scales and the place of boundaries, the logic of capital does continue to be reinscribed. So in spite of the 'newness' of the concept of knowledge economy, many of its core principles remain anchored in capital, such as economic rationalism, wealth creation, and value generation. Singapore's knowledge economy is undoubtedly situated in this context. However, as Appadurai reminds us, this global-centricity also needs to be thought of in terms of disjunctures and differences. So Singapore's attempt to assert competitive advantage has been one of spatial disjuncture, an attempt to position Singapore as a mediator or comprador between two scales: global and Asian/regional. In this sense, Singapore as a knowledge economy depended on its existence as a "global knowledge hub in Asia". In this arrangement, Singapore becomes the location through which different sorts of flow - human, capital, commodity, and information - transit. In terms of substance, Singapore's knowledge economy is also similar, as science and technology and their abstraction as value remain the primary preoccupation, while other areas that are less easily commercialised, such as the arts, humanities, and social sciences are indirectly factored in.

However, Asia has also been used by the Singapore knowledge economy in a potentially transformative way. Indeed Asia is not merely a geographical location that Singapore's knowledge hub happens to be in, but is also a systematic way of producing modes and styles of knowledge. In this connection, Singapore has increasingly sought to transform itself as an Asian area expert in fields applicable to every conceivable aspect of Singapore's repurposed economy. In this way, activities in science and technology are Asianised as are businesses and acts of entrepreneurialism, and researchers are encouraged to make Asia relevant as a site of research problems and a potential market for knowledge commodities. I have argued that Singapore's knowledge economy as a purveyor of Asian area expertise is not enough and that the knowledge economy could be explored in its alternative guise as knowledge capitalism, particularly through Marx's conception of historicism - that there are histories that reproduce the logic of capital and also histories that are disruptive of or 
external to capital's life process. These disjunctures circulate around both the reproduction of global capitalism and Singapore's ironic attempt to inscribe an Asian form of knowledge capitalism that both reproduces the former while also attempting to position Singapore as the (postcolonial) Other in relation to knowledge of the Western Other.

\section{Notes}

I Although the concept of the knowledge economy has only been articulated by Singapore government spokesmen from the mid-I990s onwards, Ramcharan reminds us that it was really in the late I980s that Singapore was, ironically, reluctantly pushed in that direction (2006: $322-4)$. This came in the form of intellectual property protection laws that were imposed by the US - part of the very same regime that the government now acclaims as one of the most vital aspects of Singapore's knowledge economy.

2 Interestingly, the most recent figure released by the iDA shows that the IT sector had I39,000 workers in 2008 . With an annualised growth rate of $6.6 \%$, this figure is likely to fall well short of the targets for 2010 (Singapore InfoComm Development Authority 2009).

3 For instance, the birth of the Journal of Southeast Asian History in I960 and the International Conference of Southeast Asian Historians a year later, and the short-lived Centre for Southeast Asian Studies. All were initiatives of the History Department in the University of Singapore.

4 At that time the company went under the name of Television Corporation of Singapore.

5 The Singaporean university curriculum was 'Americanised' because it was felt that the US university system better facilitated the development of creativity and entrepreneurialism among students. The Americanised appointment system was also intended to identify faculty member's main activity: either teaching or both teaching and research.

6 These changes to higher education in Singapore are in a broader sense not unique, as OECD countries have also converted their universities in very similar ways. This is the 'academic capitalism' that Slaughter and Rhoades (2004) write about. 


\section{About the Contributors}

Syed Muhd Khairudin Aljunied is Assistant Professor at the Department of Malay Studies, National University of Singapore. He is the author of Rethinking Raffles (Singapore: Marshall Cavendish Academic, 2005) and Colonialism, Violence and Muslims in Southeast Asia (London: Routledge, 2009). His edited volumes include Reframing Singapore: Memory, Identity and Trans-Regionalism (Amsterdam: Amsterdam University Press, 2009, co-edited with Derek Heng), Melayu: The Politics, Poetics and Paradoxes of Malayness (Singapore: Singapore University Press, 20II, coedited with Maznah Mohamad). Aljunied's current research interests lie in the overlapping areas of colonial history, the history of ideas, ethnic minorities and social identities in historical Southeast Asia. He is currently working on two major projects; a book manuscript on Malay anticolonial movements in British Malaya as well as the history and social memory of the Jabidah massacre in the Philippines (with Rommel Curaming).

Cheng Guan Ang is Associate Professor and Head of the Humanities and Social Studies Education Academic Group of the National Institute of Education (HSSE/NIE) and Adjunct Senior Fellow of the S. Rajaratnam School of International Studies. He is the author of Vietnamese Communist Relations with China and the Second Indo-China Conflict, 1956-1962 (Jefferson : MacFarland, I997), The Vietnam War from the Other Side: The Vietnamese Communists' Perspective (London: RoutledgeCurzon, 2002), Ending the Vietnam War: The Vietnamese Communists' Perspective (London: Routledge Curzon, 2004) and Southeast Asia and the Vietnam War (London: Routledge, 2010). He has also published in edited volumes as well as in journals including Asian Survey, Journal of Contemporary History, War and Society, War in History, Australian Journal of International Affairs, Security Dialogue, Southeast Asia Research, Cold War History, Asian Security and the Journal of Southeast Asian Studies. He is completing a paper on the Establishment of the Five Power Defence Arrangements (FPDA). He is currently working on three major research projects: (a) The International History of the Vietnam War: The Denouement 1967-1975 (Routledge Frank Cass, forthcoming); (b) Singapore/ ASEAN and the Third Indochina War (I978-I99I) and (c) Lee Kuan 
Yew's Strategic Thought. He was a Gerald R. Ford Foundation Research Grant Award recipient (Fall 2005), Fulbright Singapore Researcher award recipient (2006-2007) and a Woodrow Wilson Public Policy Scholar (2006-2007).

Derek Heng is Assistant Professor at the Department of History, Ohio State University, U.S.A., where he teaches pre-modern Asian history, historical thought and methodology, and world history before AD I500. His research interests include the pre-modern economic interaction between Southeast Asia and China, pre-modern state formation of coastal port states in Maritime Southeast Asia and the historiography of Singapore's past. His publications include Sino-Malay Trade and Diplomacy in the $10^{\text {th }}$ through the I4 ${ }^{\text {th }}$ Century AD (Athens: Ohio University Press, 2009) and Singapore, A Seven-Hundred Year History (Singapore: National Archives of Singapore, 2009). His edited volumes include Reframing Singapore: Memory, Identity and Trans-Regionalism (Amsterdam: Amsterdam University Press, 2009, co-edited with Syed Muhd Khairudin Aljunied), and New Perspectives and Sources on the History of Singapore: A Multi-Disciplinary Approach (Singapore: National Library Board, 2006). He is currently the editor of Berita Newsletter (Malaysia, Singapore Brunei Study Group, Association of Asian Studies, USA), and the North American representative of the Malaysian Branch of the Royal Asiatic Society.

Stephen Dobbs is the Chair of Asian Studies at the University of Western Australia. He has had a long- standing interest in the history of Singapore and has written and published on the early development of the port of Singapore along the Singapore River. His research interests include maritime history as well as environmental and social history in Southeast Asia. He is currently working on a study of various proposals to construct shipping canals through the Isthmus of Kra in southern Thailand. $\mathrm{He}$ is also working on a project with colleagues from UWA looking at questions of social justice and the role of engineers in the development of various major engineering projects along the Mekong River and its tributaries.

Huei-Ying Kuo is Assistant Professor of Asian history at the Department of Humanities and Social Sciences at Rose-Hulman Institute of Technology in Terre Haute, Indiana, where she teaches courses in East Asian regionalism, maritime China, comparative business history, and race, class and gender at work. She obtained her PhD from the Dept. of Sociology at State University of New York at Binghamton and her MA and BA in sociology at National Taiwan University. She has published articles in Journal of Contemporary Asia, Enterprise and Society: International Journal of Business History, Review: A Journal of 
the Fernand Braudel Center, China Information, among others. Her current research interests are imperialism and nationalism in East and Southeast Asia as well as Chinese overseas emigration in the making of modern capitalism.

Lai Chee Kien is Assistant Professor at the Department of Architecture, National University of Singapore, and a registered architect in Singapore. He graduated with an M Arch. by research (1996) from the National University of Singapore and a PhD in History of Architecture \& Urban Design from the University of California, Berkeley (2005). He researches on the histories of art, architecture, vernacular settlements, urbanism and landscapes in Southeast Asia. Recent research topics include post-1945 architecture \& urban design in Southeast Asia, and the peri-urban spaces and landscapes in Singapore and Malaysia. His publications include A Brief History of Malayan Art (1999) and Building Merdeka: Independence Architecture in Kuala Lumpur, 1957-1966 (2007).

Philip Holden is Associate Professor at the Department of English Language and Literature at the National University of Singapore, and is currently Deputy Director of the University Scholars Programme at the same university. His research interests include life writing and Southeast Asian writing in English, often with a focus on issues relating to gender and multiculturalism. His present research examines the place of the short story as a global form under decolonization, and he is also doing preliminary work on a literary biography of W. Somerset Maugham. He is the author of Autobiography and Decolonization: Modernity, Masculinity, and the Nation-State (2008), and co-author of The Routledge Concise History of Southeast Asian Writing in English (2009). He has also published in Postcolonial Studies, Interventions, The Journal of Postcolonial Writing, The Journal of Commonwealth Literature, Biography, Life Writing, Philippine Studies and Textual Practice.

Jason Lim is Lecturer in Asian History in the School of History and Politics at the University of Wollongong. He graduated with Honours in Asian Studies from Murdoch University in I996. In 1998 he joined the Oral History Centre as a Research Officer. In 2007 he graduated with a PhD in History and Asian Studies from the University of Western Australia. He joined the Department of History at the National University of Singapore as its Postdoctoral Fellow in 2008. His publications include Linking an Asian Transregional Commerce in Tea: Overseas Chinese Merchants in the Fujian-Singapore Trade, 1920-1960 (Brill, 2010). His current research interests include overseas Chinese history, the economic and social 
history of modern China and the social history of Malaysia and Singapore. His next publication will be on the Chinese trishaw industry of Singapore.

Kah Seng Loh is an independent scholar whose work investigates littlestudied subjects in the social and cultural history of Singapore and Malaysia and explores linkages between past and present in public history, oral history, social memory, heritage, and archival access. He is author of two books, Making and Unmaking the Asylum: Leprosy and Modernity in Singapore and Malaysia (SIRD, 2009) and The Makers and Keepers of Singapore History (co-edited, Ethos Books \& Singapore Heritage Society, 20Io), in addition to numerous articles published in peer-reviewed journals. His manuscripts on the 1961 Bukit Ho Swee fire and the University of Malaya Socialist Club are being reviewed for publication. He is currently working on book projects on the social and economic impact of the British military withdrawal from Singapore in the late I96os and on interdisciplinary approaches to oral history and memory in Southeast Asia.

S.R. Joey Long received his PhD in history from the University of Cambridge, and is currently assistant professor of history and international affairs at the S. Rajaratnam School of International Studies, Nanyang Technological University, Singapore. He is the author of Safe for Decolonization: The Eisenhower Administration, Britain, and Singapore (Kent State University Press, 20II). His articles on the history of American foreign relations, the history of Singapore, and Asian and international security have also been published in or are forthcoming from Contemporary Southeast Asia, Diplomatic History, European Journal of International Relations, Journal of Southeast Asian Studies, Rethinking History, South East Asia Research, and a number of edited volumes. Fellowships and awards he has received include a researcher grant from the J. William Fulbright Commission and the Lawrence Gelfand-Armin Rappaport Fellowship from the Society for Historians of American Foreign Relations. From March through June 2010, he was a History and Public Policy Scholar at the Woodrow Wilson International Center for Scholars in Washington, DC.

Torsten Tschacher is currently a postdoctoral researcher at the Cluster of Excellence 'Asia and Europe in a Global Context' at Heidelberg University, Germany. His research interests focus on the religious and literary traditions of Tamil-speaking Muslims in India, Sri Lanka and Southeast Asia. He is currently conducting research on the engagement of Tamil-speaking Muslims with diverse publics in colonial Singapore. His recent publications include 'Witnessing Fun: Tamil-speaking Muslims and the Imagination of Ritual in Colonial Southeast Asia', in Ritual, Caste, and Religion in Colonial South India (edited by Michael Bergunder, 
Heiko Frese and Ulrike Schröder; Verlag der Franckeschen Stiftungen $\mathrm{zu}$ Halle, 20Iо), and 'Drowning in the Ocean of Tamil: Islamic Texts and the Historiography of Tamil Literature' in Literature and Nationalist Ideology: Writing Histories of Modern Indian Languages (edited by Hans Harder; Social Science Press, 20I0).

Leong Yew is Assistant Professor in the University Scholars Programme, National University of Singapore. His first book, The Disjunctive Empire of International Relations (2003) examined the complicity between imperial discourse and contemporary 20 th century texts on international politics. He is currently engaged in the examination of Asian identities, with his edited volume Alterities in Asia: Reflections on Identity and Regionalism (20II) being one of its outcomes. His next monograph, Asianism: The Politics of Regional Consciousness in Singapore, which queries Singapore's ambivalent and simultaneous identification with and differentiation with Asia is forthcoming. 



\section{Bibliography}

Abdullah, Munshi (I970), The Hikayat Abdullah / an Annotated Translation by A.H. Hill. Kuala Lumpur; New York Oxford University Press.

Abu-Lughod, Janet L. (I989), Before European Hegemony: The World System A.D. 1250-1350. New York: Oxford University Press.

Adorno, T. (I974), Minima moralia: Reflections from Damaged Life. London: Verso.

Akashi Yōji (I970), The Nanyang Chinese National Salvation Movement, 1937-1941. Kansas: Centre for East Asian Studies, the University of Kansas.

Aljunied, Syed Muhd Khairudin (2007), "The Role of Hadramis in Post-World War Two Singapore - A Reinterpretation”, Immigrants and Minorities, 25, 2: 163-183.

- (2009a), "British Discourses and Malay Identity in Colonial Singapore". Indonesia and the Malay World, 37, I07: I-2I.

- (2009b), Colonialism, Violence and Muslims in Southeast Asia: The Maria Hertogh Controversy and Its Aftermath. London: Routledge.

Andaya, Leonard Y. (2008), Leaves of the Same Tree: Trade and Ethnicity in the Straits of Melaka. Honolulu: University of Hawai'i Press, 2008.

Appadurai, Arjun (I990), 'Disjuncture and Difference in the Global Cultural Economy', Public Culture 2, 2: I-24.

Aron, Raymond (1970), “The Evolution of Modern Strategic Thought” in Buchan, Alistair (ed.), Problems in Modern Strategy. London: Chatto and Windus.

Asad-ul Iqbal Latif, (2009), Three Sides in Search of A Triangle: Singapore-America-India Relations. Singapore: ISEAS.

Asia Research Institute (2003), Annual report. Singapore: Asia Research Institute, National University of Singapore.

Azeez, A.M.A. (1968-69), 'Some Aspects of the Muslim Society of Ceylon with Special Reference to the Eighteen-Eighties.' In Xavier S. Thani Nayagam et al. (eds.), Proceedings of the First International Conference Seminar of Tamil Studies: Kuala Lumpur - Malaysia, April 1966, 2 vols., vol. 1, 746-762. Kuala Lumpur: International Association of Tamil Research.

Ballantyne, Tony (2003), "Rereading the Archive and Opening the Nation-State: Colonial Knowledge in South Asia (and Beyond)", in Antoinette Burton (ed.), After the Imperial Turn: Thinking with and through the Nation. Durham: Duke University Press: II2-II3.

Bakhtin, M.M. (I98I), The dialogic imagination: four essays. Austin: University of Texas Press.

Barr, M. and Carl A. Trocki (ed.) (2008), Paths not taken; political pluralism in post-war Singapore. Singapore: NUS Press.

Batabyal, Rakesh (2005), Communalism in Bengal: From Famine to Noakhali, 1943-1947. London: Sage.

Bayly, C.A. (I996), Empire and Information: Intelligence Gathering and Social Communication in India, 1780-1870. Cambridge: Cambridge University Press.

Bennett, George (I967), Wanderings in New South Wales, Batavia, Pedir Coast, Singapore and China: Being the Journal of a Naturalist in Those Countries During 1832, 1833 and 1834. Facsimile edn., Australiana Facsimile Editions. Adelaide: Libraries Board of South Australia.

Bentley, Jerry H. (2006), "Globalizing History and Historicizing Globalization”, in Barry K. Gills and William R. (eds.), Globalization and Global History. New York: Routledge. 
Benton, Lauren (I996), "From the World Systems Perspective to Institutional World History: Culture and Economy in Global Theory”, Journal of World History, 7, 2: 26I-295.

Birch, E.W. (I879), 'The Vernacular Press in the Straits', Journal of the Straits Branch of the Royal Asiatic Society 4: 5I-55.

Bloodworth, Dennis (1986), The Tiger and the Trojan Horse. Singapore: Times Books International.

Blythe, Wilfred (1969), The Impact of Chinese Secret Societies in Singapore: a historical study. London and Kuala Lumpur: Oxford University Press.

Borschberg, Peter (2009), The Singapore and Melaka Straits: Violence, Security and Diplomacy in the $17^{\text {th }}$ Century. Singapore: National University of Singapore Press.

Boyce, David George (I999), Decolonisation and the British Empire, 1775-1997. New York: St. Martin's Press.

Braddell, Roland (I980), A Study of Ancient Times in the Malay Peninsula and the Straits of Malacca. Kuala Lumpur: Malaysian Branch of the Royal Asiatic Society.

Brandel, Judith and Tina Turbeville (1998), Tiger Balm Gardens: A Chinese Billionaire's Fantasy Environments. Hong Kong: The Aw Boon Haw Foundation.

Brew, S.H. Jr. (I898), 'Female education and its bearing upon the improvement of the race' Gold Coast Aborigines May 21: 3-4.

Brown, C.C. (I970), Sejarah Melayu or Malay Annals. London: Oxford University Press.

Brown, Edwin A. (2007), Indiscreet Memories: 1901 Singapore through the eyes of a colonial Englishman. Singapore: Monsoon Books.

Bryson, Norman (I990), Looking at the Overlooked: Four Essays on Still Life Painting. London: Reaktion Books.

Buck, D.D. (I997), The Declining Role of China in the International Tea Trade, 1880-1910, Occasional Paper No. 97-05, Centre for International Studies, University of Wisconsin at Milwaukee and Madison.

Buckley, Charles (I984), An Anecdotal History of Old Times in Singapore. Singapore: Oxford University Press.

Buckley, Charles Burton (I902), An Anecdotal History of Old Times in Singapore (With Portraits and Illustrations): From the Foundation of the Settlement under the Honourable the East India Company, on February $6^{\text {th }}, 1819$, to the Transfer of the Colonial Office as Part of the Colonial Possessions of the Crown on April 1 $1^{\text {st }}, 1867.2$ Volumes. Singapore: Fraser \& Neave.

Butler, L.J. (2002), Britain and Empire: Adjusting to a Post-imperial World. London; New York: I.B. Taurus.

Cameron, John (1965), Our Tropical Possessions in Malayan India. Oxford in Asia. Historical Reprints. Kuala Lumpur: Oxford University Press.

Cancoanid (1885) 'Ladies column,' Western Echo November I8: 2.

Casely Hayford, J.E. (1896) 'Hendrick Vroom, Esq., C.M.G.' Gold Coast Independent June I3: 2.

- (I9I0) 'The difficult art of thinking nationally,' Gold Coast Leader November 26: 3.

Cevattamaraikkāyar Nāvalar, Ki.A.Vu. (I886), Malākkāp piravēcattirattu. Cinkappūr: Tīnō tayavēntiracālai.

Chakrabarty, Dipesh (2000), Provincializing Europe : postcolonial thought and historical difference. Princeton, N.J: Princeton University Press.

Chan Heng Chee \& Obaid ul Haq (ed.) (1987), The Prophetic a the Political: Selected Speeches and Writings of S. Rajaratnam. Singapore: Graham Brash.

Chandra, B.C. (I957), Department of Archaeology Annual Report on Indian Epigraphy for 1956-57. New Delhi.

Charles W. Freeman Jr. (I997), The Diplomat's Dictionary. Washington DC: United States Institute of Peace Press.

Chatterjee, P. (I993) The nation and its fragments; colonial and postcolonial histories. Princeton, Princeton University Press. 
Chaudhuri, K.N. (I990), Asia Before Europe: Economy and Civilisation of the Indian Ocean from the Rise of Islam to 1750. New York: Cambridge University Press.

Chen Kezhan (ed.) (I994), Anxi huaqiao zhi [Gazetteer of overseas Chinese from Anxi, Fujian]. Xiamen: Amoy University Press.

Chen Mong Hock (I967), The Early Chinese Newspapers of Singapore, 1881-1912. Singapore: University of Malaya Press.

Chen Tianlai (1938), Dōgyō kumiai taiwan chashō gōkai enkaku-shi [History of the Guild of Taiwan Tea Agencies]. Taibeishi: Dōgyō kumiai taiwan chashō gōkai.

Chen, Chuan 陈橡 (I993), Zhongguo Chaye Waixiao Shi 中国茶叶外销史 (A history of the Chinese tea trade), Taipei: Bishanyan Chuban.

Chen, Fu Sheng (I947), 'Fukien Exports Slump Due to War; People's Livelihood Endangered', The China Weekly Review, 105 (10): 270.

Chen, Jiarong \& Qian, Jiang (2000), Zhufanzhi zhubu. Hong Kong: Hong Kong University Press.

Chen, Peter. (200I), 'Keynote Address at the Ioth Global Conference on the Harvard Project for Asian and International Relations, on Monday 27th August 200I at 9.20 am at the Suntec City Auditorium'. http://www.moe.gov.sg/media/speeches/200I/sp2808200I.htm

Chen, Ta (1978), Emigrant Communities in South China: A Study of Overseas Migration and its Influence on Standards of Living and Social Change, first published by the Secretariat of the Institute of Pacific Relations in New York in I940, New York: AMS.

Chew, Melanie (1998), Of Hearts and Minds: The Story of Sembawang Shipyard. Singapore: Sembawang Shipyard Pte Ltd.

Chi, Ch'ao-ting (I980), Wartime Economic Development of China, first published by the International Secretariat of the Institute of Pacific Relations in New York in I939, New York: Garland Publishing.

Chin Kin Wah (1983), The Defence of Malaysia and Singapore: The Transformation of a Security System, 1957-1971. Cambridge: Cambridge University Press.

Chin Peng (2003), My side of history, Singapore: Media Masters.

Chin, C.C. and Karl Hack (ed.) (2004) Dialogues with Chin Peng; new light on the Malayan Communist Party. Singapore: Singapore University Press.

Ching, Leo (2000), 'Globalizing the Regional, Regionalizing the Global: Mass Culture and Asianism in the Age of Late Capital', Public Culture I2, I: 233-57.

Choo, Eng Kang (1976), 'The Singapore Trade Depression, I900-22', Academic Exercise in History, University of Singapore.

Chua Ai Lin (2008a), 'Modernity, popular culture and urban life: Anglophone Asians in colonial Singapore, I920-I940, Ph.D. diss., University of Cambridge.

- (2008b), 'Imperial Subjects, Straits Citizens: Anglophone Asians and the Struggle for Political Rights in Inter-War Singapore.’ In Michael D. Barr and Carl A. Trocki (eds.), Paths not Taken: Political Pluralism in Post-War Singapore, 16-36. Singapore: NUS Press.

Chua Mui Hoong (I996), 'PM Goh to NUS and NTU - Aim to Become World Class', The Straits Times 22 September.

Chua, Beng-Huat (I995), Communitarian Ideology and Democracy in Singapore. London and New York: Routledge.

Chūka Kaikan [The Chinese Association] (2000), Roku chi sei kon: Kôbe kakyô yo shin-han chukakaikan hyakunen-shi [Roots in a New Homeland: A Hundred Years of Chinese in Kōbe-Ōasaka and their Association]. Tokyo: Kenbun shuppan.

Clark, Hugh (2002), Community, Trade and Networks; Southern Fujian Province from the Third to the Thirteenth Century. Cambridge: Cambridge University Press.

Clunas, Craig (1996), Fruitful Sites: Garden Culture in Ming Dynasty China. Durham: Duke University Press.

Clutterbuck, Richard (1984), Conflict and Violence in Singapore and Malaysia, 1945-1983. Singapore: Graham Brash, revised ed. 
Cody, Mary Kilcline (200I), "Mis-Fits in the Text: The Singapore Riots of 1950". Unpublished Academic Exercise submitted to the Faculty of Asian Studies, Australian National University. Coedes, George (1930), "Les inscriptions malaises de Crivijaya." BEFEO 30, I-2: 29-80.

- (I964), Les estats hindouises d'Indochine et d'Indonesie. Paris: Boccard, I964.

Colony of the Straits Settlements (1888), Blue Book for the Year 1887. Singapore: Government Printing Office.

Conceicao, Joe (2007), Singapore and the Many-Headed Monster. Horizon Books: Singapore.

Cooper, Frederick (2005), Colonialism in Question: Theory, Knowledge, History. Berkeley, University of California Press.

Coronil, Fernando (2000), 'Toward a Critique of Globalcentrism: Speculations on Capitalism's Nature', Public Culture I2, 2: 35I-74.

Cortesao, Armando (1944), The Suma Oriental of Tomè Pires and The Book of Francisco Rodrigues. London: The Hakluyt Society.

Craig, James (I99I), 'Escape from the Fortress Colony: The Politics of Economic Diversification in Malta'. In James Mayall and Anthony Payne eds. The Fallacies of Hope: The Post-colonial Record of the Commonwealth Third World. Manchester: Manchester University Press: 129-42.

Danahay, M.A. (2005), Gender at work in Victorian culture. Aldershot: Ashgate.

Daniel, Norman (1966), Islam, Europe and Empire. Edinburgh: Edinburgh University Press.

Darby, Philip (1973), British Defence Policy East of Suez, 1947-1968. London: Oxford University Press for the Royal Institute of International Affairs.

Darwin, John (I988), Britain and Decolonisation: The Retreat from Empire in the Post-war World. Basingstoke: Macmillan Education.

Darwin, John (199I), 'Britain's Withdrawal from East of Suez. In Carl Bridge ed. Munich to Vietnam: Australia's Relations with Britain and the United States since the 1930s. Carlton, Victoria: Melbourne University Press: 140-58.

Davidson, G.F. (I846), Trade and Travel in the Far East or Recollections of Twenty-One Years Passed in Java, Singapore, Australia, and China. London: Madden and Malcolm.

Davidson, Jamie S. (2008), From Rebellion to Riots: Collective Violence on Indonesian Borneo. Madison: University of Wisconsin Press.

de Querbeuf, Y.M.H. (1780), Lettres edifiantes et curieuses, ecrites des missions étrangères (de la Compagnie de Jesus), vol. I6. Paris: J. G. Merigot.

Derrida, Jacques (2000), Of Hospitality: Anne Dufourmantelle Invites Jacques Derrida to Respond (R. Bowlby, Trans.). Stanford: Stanford University Press.

Dingman, Roger (I989), 'John Foster Dulles and the Creation of the South-East Asia Treaty Organization', International History Review II (3): 457-477.

Dirlik, Arif (2005), "Performing the World: Reality and Representation in the Making of World Histor(ies)", Journal of World History, I6, 4: 39I-4IO.

Dobson, Mirian and Ziemann, Benjamin (ed.) (2009), Reading Primary Sources: The Interpretation of Texts from Nineteenth- and Twentieth-Century History. London: Routledge.

Drysdale, John (1984), Singapore: Struggle for Success. Singapore: Times Books International.

Duara, Prasenjit (2009), The Global and Regional in China's Nation-Formation. London: Routledge.

Dunn, Ross E. (1985), "The Challenge of Hemispheric History (1000-I500 A.D.)", The History Teacher, 18, 3: 329-338.

Earl, George Windsor (1971), The Eastern Seas or Voyages and Adventures in the Indian Archipelago, in 1832-33-34. New York: Oxford University Press.

Eng, Annie Li Kheng (1974), A Report on the September 1974 Ngee Ann Technical College Graduate Employment Survey. University of Singapore, Economic Research Centre. 
Farish A. Noor (2004), Islam Embedded: The Historical Development of the Pan-Malaysian Islamic Party PAS (1951-3302) Vol. I. Kuala Lumpur: Malaysian Sociological Research Institute.

Fernandez-Armesto, Felipe (2006), The World, A History. Saddleback: Prentice Hall.

Firdaus Haji Abdullah (I985), Radical Malay Politics: Its Origins and Early Development. Pelanduk Publications: Petaling Jaya.

Fong Sip Chee (I980), The PAP Story: The Pioneering Years. Singapore: Times Periodicals.

Frost, M. Ravinder (2003), 'Transcultural Diaspora: the Straits Chinese in Singapore, I8I9-I918.' Asia Research Institute Working Paper 10. Singapore: Asia Research Institute, National University of Singapore. <http://www.ari.nus.edu.sg/docs/wps/wpso3_oro.pdf>

- (2004), 'Asia's Maritime Networks and the Colonial Public Sphere, I840-I920', New Zealand Journal of Asian Studies 6(2): 63-94.

Gandhi, M.K. (I997), Hind swaraj and other writings. Ed. Anthony J. Pael. Cambridge: Cambridge University Press.

Garrard, Charles Goodricke (ed.) (I898), The Acts and Ordinances of the Legislative Council of the Straits Settlements, from the $1^{\text {st }}$ April 1867 to the $7^{\text {th }}$ March 1898 . In Two Volumes. London: Eyre and Spottiswoode.

Gocking, R.S. (I999), Facing two ways: Ghana's coastal communities under colonial rule. Lanham: University Press of America.

- (2005), The history of Ghana. Westport, Connecticut: Greenwood, 2005.

Goh Chok Tong (200I), Speech at the National Day Rally. National University of Singapore, Singapore. I9 August. Singapore: Ministry of Information and the Arts.

- (2005), 'Reconceptualizing East Asia', Keynote address at the official launch of the Institute of South Asian Studies. Orchard Hotel, Singapore.

Goh, K.S. (I960a), 'Rectification of the English-educated.' Petir 3 (7): 7, 8.

- (I960b), 'Rectification of the English-educated.' Petir 3 (9): 4-5.

Goh, Che Cheng Jace (I987), 'The Chinese Huiguan in Singapore (I945-1959)', Academic Exercise in History, National University of Singapore.

Goscha, Christopher \& Christian Ostermann (ed.) (2009), Connecting Histories: Decolonization and the Cold War in Southeast Asia, 1945-1962. Washington, DC: Woodrow Wilson Center Press; and Stanford, CA: Stanford University Press.

Gotō Ken'ichi (I995), Kindai Nihon to Tōnan Ajia : nanshin no 'shōgeki' to “isan' [Modern Japan and Southeast Asia: impacts and legacy of southward advance]. Tōkyō : Iwanami Shoten.

Gōto Ken'ichi (2003), Tensions of Empire: Japan and Southeast Asia in the Colonial and Postcolonial World. Singapore: Singapore University Press.

Griffith, Tom (I997), The Travels of Marco Polo. Hertfordshire: Wordsworth.

Groeneveldt, W.P. (I876), Historical Notes on Indonesia and Malaysia Compiled from Chinese Sources. Batavia: S.N., I876.

Groff, George Weidman (I921), The Lychee and Lungan. New York: Orange Judd Company.

Guillot, Claude (ed.) (I998), Histoire de Barus, Sumatra; le site de Lobu Tua. Paris: Association Archipel.

Gullick, J.M. (I958), Indigenous Political Systems of Western Malaysia. London: University of London, Athlone Press.

Guo Chunyang (I9ı9a), 'Nan'yō bōeki to kakyō [South Seas trade and overseas Chinese]', Nan’yō Kyōkai Zasshi Vol. 5, no. 5: 4I-44.

- (I9I9b), 'Kaku Shun'ō-shi yori [From Mr. Guo Chunyang],' Nan’yō Kyōkai Zasshi 5, no. Iо: 83 .

Habermas, Jürgen (I990), Strukturwandel der Öffentlichkeit. Second Edition. Frankfurt am Main: Suhrkamp Verlag. 
Hack, Karl (200Ia), Defence and Decolonisation in Southeast Asia: Britain, Malaya and Singapore 1941-1968. Richmond: Curzon Press.

- (200Ib), Defence and Decolonisation. Richmond: Curzon Press.

Haja Maideen (I989), The Nadra Tragedy. Pelanduk Publications: Petaling Jaya.

Hall, Kenneth R. (I978), "International Trade and Foreign Diplomacy in Early Medieval South India”, Journal of the Economic and Social History of the Orient, 2I, I: 75-98.

- (1985), Maritime Trade and State Development in Early Southeast Asia. Honolulu: University of Hawai'i Press.

- (200I), "Upstream and Downstream Unification in Southeast Asia's First Islamic Polity: The Changing Sense of Community in the Fifteenth Century "Hikayat Raja-Raja Pasai" Court Chronicle", Journal of the Economic and Social History of the Orient, 44, 2: 198-229.

- (20I0), "Ports-of-Trade, Maritime Diasporas, and Networks of Trade and Cultural Integration in the Bay of Bengal Region of the Indian Ocean: C. I300-I500", Journal of the Economic and Social History of the Orient, 53, I-2: I09-I45.

Halle, Louis J. (I960), American Foreign Policy: Theory and Reality. London: Bradford \& Dickens. Han, Tan Juan (2008), 'Han Wai Toon and the Legacy of the Sembawang Rambutan Garden'. In Low Sze Wee and Chow Yian Ping eds., Xu Beihong in Nanyang, II7-I23. Singapore: Singapore Art Museum.

Han, Wai Toon (I953), 'The Planting of Rambutans'. In Journal of the South Seas Society, 9, 2.

- (I960), Ancient Chinese Export Ware found in Nanyang. Singapore: The Youth Book Company.

Harper, T.N. (I997), 'Globalism and the Politics of Authenticity: The Creation of a Diasporic Public Sphere in Singapore', Sojourn I2 (2): 26 I-292.

- (I997), 'Globalism and the Pursuit of Authenticity: The Making of a Diasporic Public Sphere in Singapore', Sojourn: Journal of Social Issues in Southeast Asia I2 (2): 26I-292.

- (200I), 'Lim Chin Siong and the 'Singapore Story', in Tan Jing Quee and K.S. Jomo (ed.), Comet in the sky: Lim Chin Siong in history, 3-55. Kuala Lumpur: INSAN.

He, Simi 何思眯 (I997), Kangzhan Shiqi De Zhuanmai Shiye (1941-1945) 抗战时期的专卖事业 (一九四一 一九四五) (The monopoly during Sino-Japanese War, I94I-I945), Taipei: Academia Historica.

Heng Pek Koon (1988), Chinese Politics in Malaysia: A History of the Malaysian Chinese Association. Oxford and New York: Oxford University Press.

Heng, Derek (2004), "Economic Exchanges and Linkages between the Malay Region and the Hinterland of China's Coastal Ports during the $10^{\text {th }}$ to $14^{\text {th }}$ centuries" in John N. Miksic \& Cheryl-Ann Low Mei Gek (eds.), Early Singapore, 1300s-1819; Evidence in Maps, Text and Artefacts, 73-85. Singapore: Singapore History Museum.

- (2006), "Export Commodity and Regional Currency: The Role of Chinese Copper Coins in the Malacca Straits Region, Tenth to Fourteenth Centuries"; Journal of Southeast Asian Studies, 37, 2: 179-203.

- (2009), Sino-Malay Trade and Diplomacy from the Tenth through the Fourteenth Century. Athens: Ohio University Press.

Heng, Derek Thiam Soon (I999), “Temasik as an International and Regional Trading Port in the Thirteenth and Fourteenth Centuries: A Reconstruction Based on Recent Archaeological Data", Journal of the Malaysian Branch of the Royal Asiatic Society, 72, I: II3-I24.

- (200I), "The trade in lakawood products between South China and the Malay world from the twelfth to fifteenth centuries AD", Journal of Southeast Asian Studies, 32, 2: I33-I49.

- (2002), "Reconstructing Banzu, a Fourteenth Century Port Settlement in Singapore", Journal of the Malaysian Branch of the Royal Asiatic Society (henceforth JMBRAS), 75, I: 69-90.

- (2008), "Structures, Networks and Commercial Practices of Private Chinese Maritime Traders in Island Southeast Asia in the Early Second Millennium AD", International Journal of Maritime History, 20, 2: 27-54.

Heng, Derek, \& Syed Muhd Khairudin Aljunied (ed.) (2009), Reframing Singapore: Memory Identity - Trans-Regionalism. Amsterdam: Amsterdam University Press. 
Heng, Derek, Kwa Chong Guan, \& Tan Tai Yong (2009), Singapore: A 700-Year History - From Early Emporium to World City. Singapore: National Archives of Singapore.

Hill, A. H. (I960), "Hikayat Raja-Raja Pasai, a revised romanised version", Journal of the Malaysian Branch, Royal Asiatic Society, 33, 2.

Ho, Engseng (2005), The Graves of Tarim: Genealogy and Mobility across the Indian Ocean. Berkeley: University of California Press.

Hoad, Neville (2009), paper given at 'Why Homosexuality? Religion, Globalization and the Anglican Schism' conference, Yale University, I7 October 2009.

Hodgson, Marshall G. S. (I974), The Venture Of Islam: Conscience And History In A World Civilization. Chicago: University of Chicago Press.

Hodgson, Marshall G. S. (I995), Rethinking World History. Cambridge: Cambridge University Press.

Holt, P.M. (1977), The Mahdist State in the Sudan 1881-1898: A Study of its Origins Development and Overthrow. Second Edition. Nairobi: Oxford University Press.

Hon Sui Sen (I973), Annual Budget Statement: Survey of the Economic Scene, Speech delivered in Parliament 26-27 February 1973. Singapore: Ministry of Culture.

Hong Lysa \& Huang Jianli (2008), The Scripting of a National History: Singapore and Its Pasts. Singapore: NUS Press.

Horimoto Naohiko (I997), 'Shingapōru no kanin kōni undō to hihōn sō keizai dantai [Chinese anti-Japanese activities and Japanese-associated economic groups]', in Namikata Shôichi (ed.) Kindai ajia no nihonjin keizai dantai, Ch. ıo. Tōkyo: Dōbunkan shūbban-sha kabushikigaisha.

Horne, Gerlad (2004), Race War: White Supremacy and the Japanese Attack on the British Empire. New York and London: New York University Press.

Hotta Eri (2007), Pan-Asianism and Japan's War, 1931-1945. New York: Palgrave MacMillan.

Hsu Hsueh-Chi (I992), 'Riju shiqi de banqiao linjia [The Lin family of Banqiao during Taiwan's Japanese colonial era],' in Institute of Modern History, Academia Sinica (eds.), Family Process and Political Process in Modern Chinese History, 657-697. Taipei: Institute of the Modern Chinese History, Academia Sinica.

- (I999), 'Riju shiqi Wufong Linjia de shanye jingying chutan [A preliminary study on business management of the Lins in Wufong],' in Huang Fusan, Wong Jiayin (eds.) Taiwan shangye chuantong lunwenji [Essays on Taiwan's Business Tradition], 297-356. Taipei: Preparatory Office of the Institute of Taiwan History, Academia Sinica.

Hsu, Yun T'siao (1962), 'Farewell to Mr. Han Wai Toon'. In Chronicles of Nanyang (original in Sin Chew Jit Poh), 3, 6: 70-72.

- (I970), 'An Eulogy for Mr. Han Wai Toon'. In Journal of Southeast Asian Researches, 6: 37-44.

Hsü, Marco [Ma Ge] (I962), 'Remembering Mr. Han Wai Toon'. In Chronicles of Nanyang (original in Nanfang Evening News), 3, 6: 37-38.

Hsü, Marco [Ma Ge] (i967), 'Han Rambutan Orchard painting and the colophons'. In Ming Pao, 27 March I967: 4.

Huang Jianli (I995), 'The Founding of the PRC and the Economic Concerns of Singapore Chinese Entrepreneurs', in Leo Suryadinata (ed.), Southeast Asian Chinese and China: The Politico-Economic Dimension, I6I-I92. Singapore: Times Academic Press.

- (2008) 'The Young Pathfinders: Portrayal of Student Activism', in Barr and Trocki (eds.), I88-205.

Huang, Pao Fang (1983), 'Remembering Mr. Han Wai Toon'. In Yin Yu Ji (The Jade Chronicles), 209-2II. Singapore: SNPL Book Publications Department.

Huff, W.G. (I994), The Economic Growth of Singapore: Trade and Development in the Twentieth Century. Cambridge: Cambridge University Press.

Hughes, T.J. and D.E.T. Luard (I96I), The Economic Development of Communist China, 1949-1960, London: Oxford University Press. 
Hughes, Tom Eames (I980), Tangled Worlds: The Story of Maria Hertogh. Institute of Southeast Asian Studies: Singapore.

Hyam, Ronald (2006), Britain's Declining Empire: The Road to Decolonisation, 1918-1968. Cambridge; New York: Cambridge University Press.

Ide Kiwata (1938), 'Fukken minzoku to Nan’yō kakyō [Fujian people and Chinese immigrants in the South Seas]', Nan'yō Kyökai Zasshin 24, no. 5: 25-36.

Inoue Masaji (I9I7), 'Nan'yō ni okeru hon-hōjin no kigyō [Our Japanese enterprises in the South Seas],' Nan'yō Kyōkai Zasshi 3, no. 5: I94-20I.

— (I942), Nanpō kaitaku wo kataru [Talk about pioneering in the south]. Tōkyō: Unebi shobō.

Institute of Southeast Asian Studies (I998), Institute of Southeast Asian Studies: a commemorative history 1968-1998. Singapore: ISEAS.

Jabatan Muzium- Muzium Brunei (2004), Sungai Limau Manis : tapak arkeologi abad ke-10-13 Masihi. Bandar Seri Begawan: Jabatan Muzium- Muzium Brunei, Kementerian Kebudayaan, Belia dan Sukan.

Jackson, James C. (1968), Planters and Speculators: Chinese and European Agricultural Enterprise in Malaya 1786-1921. Singapore: University of Malaya Press.

James, William (I880), "Great Men, Great Thoughts and the Environment", Atlantic Monthly, 46, 276: 44I-459. http://www.cscs.umich.edu/ crshalizi/James/great_men.html

Jeffries, Charles (1952), The Colonial Police. London: Max Parrish.

Jones, Matthew (2003), 'Up the Garden Path? Britain's Nuclear History in the Far East, I954-I962', International History Review 25 (2): 306-333.

Kanan Ginkō (I932), Nan'yō ni okeru konponteki hōjin hatten-saku toshite no ichi-kōsatsu [Survey of the fundamental development of the Japanese in the South Seas]. Kanan Ginkō.

Kaneo Fumio (I980), 'Ide Kiwata to Nihon no nanshin saisaku [Ide Kiwata and Japan's policies on southward advance]'. In Historical Studies of Taiwan in Modern Time 1980, no. $3: 67-85$.

Kawarabayashi Naoto (2000), Taiwan chagyō no rekishiteki tenkai: Nihon shokuminchi ni okeru taigai bōeki katsudō [Emergence of the history of the Taiwan tea industry: foreign trade of a Japanese colony] Ph.D. Dissertation of Ōsaka shiritsu daigaku gakuin.

- (2007), 'Teiko Nihon no etsukyō shakai no jinmyaku, Nan'yō kyōkai toiu kagami [Social Networks in the Expansion of Imperial Japan: Study of the South Sea Association,' in Asano Toyomi (ed.), Nan'yō guntō no teikō kokusai chitsujyō, 97-I38. Nagoyashi: Chukyo University.

Kazuki Sato (1997), 'Same Language, Same Race": The Dilemma of Kanbun in Modern Japan' in Frank Dikötter (ed.), The construction of racial identities in China and Japan, II8-I35. Honolulu: University of Hawaii Press.

Keith, Michael (1993), Race, Riots and Policing: Lore and Disorder in a Multi-Racist Society. London: UCL Press.

Kenway, Jane, Elizabeth Bullen, Johannah Fahey and Simon Robb (2006), Haunting the Knowledge Economy. London and New York: Routledge.

Keswick, Maggie (2002), The Chinese Garden: History, Art and Architecture. London: Frances Lincoln.

Kikakuin (I940), Kakyō Kenkyō Shiryō [Research Data on Chinese Sojourners]. Tōkyo: Kikakuin.

Kimble, D. (1963), A political history of Ghana: the rise of Gold Coast nationalism, 1850-1928. Oxford: Clarendon Press.

Kimura Masutarō (1919), 'Nan'yō hatten-saku ni tsuite' [Proposal of strategies to engage in the development of the South Seas],' Nan'yō Kyōkai Zasshi 5, no. 5: 32-40.

- (I920), 'Nihon tai nan'yō no keizai kankei-jyō [Economic relationship between Japan and the South Seas-first section]', Nan'yō Kyōkai Zasshi 6, no. II: 9-2I. 
- (I92I), 'Nan'yō keizai-kai to chinretsu-kan no jigyō [Tasks for the economic circle of the South Seas], Nan'yō Kyōkai Zasshi 7, no. 8: I4-22.

Ko Kheng Hwa (2003), 'Knowledge Powers Singapore Economy'. Information Age. http://www.infoage.idg.com.au/index.php/id;16268078ı2

Kobayashi Shinsaku (I93I), Shina minzoku no kaigai hatten: Kakyō no kenkyō [Overseas development of the Chinese people: Research of the Chinese sojourners]. Tokyo: Kaigai-sha.

Koh, Tommy (2003), Speech at the official opening of Asian Civilisations Museum. Asian Civilisations Museum, Empress Place, Singapore.

Kong, Lily (2008), 'Word from the Director', ARI News March: 2-3.

Ku Hong-Ting (1994), Dongnanya huaqiao de rentong wenti: Malaya pian [The problem of identities of the Chinese sojourners in Southeast Asia: research on Malaya]. Taipei: Lianjing chubanshe.

Kulke, Hermann (1993), "'Kadatuan Srivijaya' - Empire or Kraton of Srivijaya? A Reassessment of the Epigraphical Evidence", Bulletin de l'Ecole Franciase d'Extreme Orient, 80, I: 159-180.

Kuo, Huei-Ying (2006a), 'Rescuing businesses through transnationalism: embedded Chinese enterprise and nationalist activities in Singapore in the I930s Great Depression', Enterprise and Society: International Journal of Business History 7, no. I: 98-I27.

Kuo, Huei-Ying (2006b), 'Chinese bourgeois nationalism in Hong Kong and Singapore in the I930s', Journal of Contemporary Asia 36, no. 3: 385-405.

- (2009), 'Agency amid incorporation: Chinese business networks in Hong Kong and Singapore and the colonial origins of the resurgence of East Asia, I800-I940', Review: Fernand Braudel Center 32, 3: 21I-237.

Kuwabara, J. (1928), “On P’u Shou-Keng.” Toyo Bunko Research Department Memoirs 2: I-79.

Kwa Chong Guan (2004a) 'Sailing past Singapore' in John N. Miksic and Cheryl-Ann Low Mei Gek, (eds.), Early Singapore 1300s-1819: evidence in maps, texts and artefacts, 95-I05. Singapore: Singapore History Museum.

— (2004b), "From Temasik to Singapore: Locating a Global City-State in the Cycles of Melaka Straits History", in John N. Miksic \& Cheryl-Ann Low Mei Gek (eds.), Early Singapore, 130os1819; Evidence in Maps, Text and Artefacts, I24-I46. Singapore: Singapore History Museum.

Kwa Chong Guan, Tan Tai Yong and D. Heng (2009), Singapore: A 700-Year history. Singapore: National Archives of Singapore.

Laffan, Michael Francis (2003), Islamic Nationhood and Colonial Indonesia: The umma below the Winds. London and New York: RoutledgeCurzon.

Laing, Ellen Johnston (1968), 'Real or Ideal: the Problem of the "Elegant Gathering in the Western Garden" in Chinese Historical and Art Historical Records'. In Journal of the American Oriental Society, 88, 3: 419-435.

Lam P.E. and Kevin Y.L. Tan (ed.) (I999), Lee's lieutenants: Singapore's old guard. St Leonards: Allen and Unwin.

Lau, Albert (2004), 'The National Past and the Writing of the History of Singapore', in Ban Kah Choon, Anne Pakir, \& Tong Chee Kiong (ed.), Imagining Singapore, 34-53. Singapore: Eastern Universities Press.

Ledger, S. (1997), The new woman: fiction and feminism at the fin de siècle. Manchester, Manchester University Press.

Lee, John Michael (I967), Colonial Development and Good Government. Oxford: Oxford University Press.

Lee Kuan Yew (1959) 'Text of an address by the Prime Minister, Mr. Lee Kuan Yew, at the Singapore Union of Journalists Lunch at the Cathay Dragon Room on Sunday, August I6, I959.' Singapore Government Press Statement INFS. AU. 66/59.

- (I998), The Singapore Story: Memoirs of Lee Kuan Yew. Singapore: Times Editions, Singapore Press Holdings. 
- (2000), From Third World to First: The Singapore Story: 1965-2000. Singapore: Singapore Press Holdings and Times Editions.

- (2002), 'China in Transition'. Speech at East Asian Institute's 5th Anniversary.

- (2009), Lee Kuan Yew, The Fundamentals of Singapore's Foreign Policy: Then \& Now. Singapore: MFA Diplomatic Academy.

Lee Soo Ann (1971), 'The British Withdrawal and Singapore's Economic Future'. Papers on Economic Planning and Development in Singapore. Singapore: Federal Publications: 52-64.

Lee Ting Hui (1996), The Open united front: The Communist struggle in Singapore, 1954-1966. Singapore: South Seas Society.

Lee, Edwin (2008), Singapore: The Unexpected Nation. Singapore: Institute of Southeast Asian Studies.

Leifer, Michael (2000), Singapore's Foreign Policy: Coping with Vulnerability. London: Routledge.

Leong, Steven (1977), 'The Kuomintang-Communist united front in Malaya during the national salvation period, I937-I94I, Journal of Southeast Asian Studies 8, no. I: 3I-47.

- (1979), 'The Malayan overseas Chinese and the Sino-Japanese war, I937-I94I', Journal of Southeast Asian Studies 1o, no. 2: 293-320.

Lew S.F. (I898), 'A Victim of chap-ji-ki,' Straits Chinese Magazine 2: 70-72.

— (I900), 'Lost and found,' Straits Chinese Magazine 4: I74-I78.

- (I901a) 'The correspondence of Lew See Fah: Straits Chinese fathers' Straits Chinese Magazine 5: 48-50.

- (Igorb), 'The correspondence of Lew See Fah: Straits Chinese youths' Straits Chinese Magazine 5: I37-I4O.

Li, Shih-chen (Ming, I994), Ben Cao Gang Mu (Compendium of Materia Medica). Edited by Qi Hao. Beijing: Xue Yuan Publishers.

Lian, Shi Sheng (1955), 'Visiting the Han Rambutan Orchard'. Nan Xing Ji (Chronicles of Southern Journeys), I00-IO4. Singapore: Nanyang Publishers.

Lieberman, Victor B. (2003), Strange Parallels: Southeast Asia in Global Context, c. 800-1830. Cambridge: Cambridge University Press.

- (2009), Strange Parallels: Southeast Asia in Global Context, c. 800-1830. Volume 2: Mainland Mirrors: Europe, Japan, China, South Asia, and the Islands. Cambridge: Cambridge University Press.

Liew Kai Khiun (2004), 'The Anchor and the voice of Io,००0 waterfront workers: Jamit Singh in the Singapore Story (1954-63)', Journal of Southeast Asian Studies, 35, 3: 459-78.

- (2006), 'Labour formation, identity, and resistance in HM dockyard, Singapore (I92I-I97I)', International Review of Social History, 5I, 3: 4I5-39.

- (2006), 'Labour Formation, Identity, and Resistance in HM Dockyard, Singapore (I92II97I)'. Internationaal Instituut voor Sociale Geschiedenis, 5I: 4I5-39.

Lim Ah Poh (1974), Changes in Land Use in the Former British Military Areas in Singapore. Unpublished academic exercise. Department of Geography, University of Singapore.

Lim, Jason (2007), 'The Education Concerns and Political Outlook of Lim Keng Lian (I893I968)', Journal of Chinese Overseas, 3, no. 2: 194-219.

Lim, Jason (2008), 'The Promotion of Fujian Tea as a Chinese National Product in Singapore, I932-I940', Journal of the South Seas Society, 62: I27-I45.

Lim, Jason (2010), Linking an Asian Transregional Commerce in Tea: Overseas-Chinese Merchants in the Fujian-Singapore Trade, 1920-1960. Leiden \& Boston: Brill.

Lim, Mu Hue (2005), Lim Mu Hue Woodcut Prints. Singapore: New Arts Graphics Sdn. Bhd.

Lin Man-houng (200I), 'Overseas Chinese merchants and multiple nationality: a means for reducing commercial risk (I895-I935)', Modern Asian Studies 35, no. 4: 985-1009.

Lin Xiantang (2000), Guanyuan xiansheng riji, Vol. 1 [Diary of Mr. Guanyuan, Vol. r]. Taipei: Academia Sinica.

Lin Xing 林星 (2004), 'Jindai Fujian Chengshi Fazhan Yanjiu (1843-1949): Yi Fuzhou, Xiamen Wei Zhongxin' 近代福建城市发展研究(I843-1949年) 以福州、厦门为中心 (Research into the development of cities in Fujian during the modern era, with Fuzhou and Xiamen 
as examples), PhD thesis in History, Xiamen University, Xiamen, Fujian Province, People's Republic of China.

Lin, W.C. [i.e. Lim Boon Keng] (I900), 'Straits Chinese hedonism,' Straits Chinese Magazine 4: IO8-III.

Lin, W.C. [i.e. Lim Boon Keng] (I899), 'Some local Chinese worthies I: Seah Eu Chin,' Straits Chinese Magazine 3: 80-85.

Lindsay, Jennifer (2003), 'Roundtable on Research Priorities for Asia', ARI: Newsletter of the Asia Research Institute August: 2.

Lockard, Craig (I995), "Integrating Southeast Asia into the Framework of World History: The Period before I500", The History Teacher, 29, I: 7-35.

Logan, J.R. (I854), "Notices of Singapore", The Journal of the Indian Archipelago and Eastern Seas, 9 .

Loh Kah Seng (2004), 'Beyond 'Rubber Prices' History: Life in Singapore during the Great Depression Years', Master's thesis in History, National University of Singapore.

- (2009a), 'Change and Conflict at the Margins: Emergency Kampong Clearance and the Making of Modern Singapore’. Asian Studies Review. 33 (2), June: I39-59.

- (2009b), 'Kampong, Fire, Nation: Towards a Social History of Postwar Singapore'. Journal of Southeast Asian Studies. 40 (3). October: 6r3-43.

Louis, Wm. Roger \& Ronald Robinson (I994), 'The Imperialism of Decolonization', Journal of Imperial and Commonwealth History 22 (3): 462-5II.

Louis, Wm. Roger (1987), Imperialism at Bay: The United States and the Decolonization of the British Empire, 1941-1945. New York: Oxford University Press.

Ma, Huan (I970, translated by J.V.G. Mills), Ying-yai Sheng-lan: The Overall Survey of the Ocean's Shores. Cambridge: Cambridge University Press.

MacLeod, Scott \& MacGee, T.G. (I996), "The Singapore-Johor-Riau Growth Triangle: An Emerging Extended Metropolitan Region” in Fu-Chen Lo \& Yue-Man Yueng (eds.), Emerging World Cities in Pacific Asia, 4I7-464. New York: United National University Press.

Manguin, Pierre-Yves (I99I), “The Merchant and the King: Political Myths of Southeast Asian Coastal Polities", Indonesia, 52: 47-52.

- (2002), "The Amorphous Nature of Coastal Polities in Insular Southeast Asia: Restricted Centres, Extended Peripheries", Moussons, 5: 73-99.

Mao, Qixiong 毛起雄 and Lin Xiaodong 林晓东 (1993), Zhongguo Qiaowu Zhengce Gaishu 东中国侨务政策概述 (A brief outline of policies on the overseas Chinese in China), Beijing: Zhongguo Huaqiao Chubanshe.

March, Andrew (I966), 'Self and Landscape in Su Shih'. In Journal of the American Oriental Society, 86, 4: 377-396.

Marwick, Arthur (I987), The Nature of History. London: Macmillan Education Limited.

Masabuchi Sahei (I930), 'Waga kuni Nan’yō bōeki kigyō [Our country's business enterprises in the South Seas]', Nan'yō Kyōkai Zasshi I6, no. 6: 2I-34.

Masao Tōkichi (I9I9), 'Nan'yō hai-ka undō no kyōkun [Lessons from boycotting movements in the South Seas],' Nan'yō Kyōkai Zasshi 5, no. Io: 4-8.

McKinnon, E. Edwards (1984), Kota Cina: Its Context and Meaning in the Trade of Southeast Asia in the Twelfth to Fourteenth Centuries; vol.I \& 2. Unpublished PhD Thesis, Cornell University.

McNeill, William (1963), The Rise of the West. Chicago: University of Chicago Press.

Meulen, W.J. van der (I977), "In Search of Ho-Ling”, Indonesia 23: 90.

Mi Rucheng ed. (2002), Zhonghua minguo tielu shiliao, 1919-1949 [Historical data on railways in Republic of China, I9I9-I949]. Beijing: Beijing shehui kexue wenxian chubanshe.

Miksic, John N. (1985), Archaeological Research on the "Forbidden Hill" of Singapore: Excavations at Fort Canning. Singapore: National Heritage Board.

- (2000), "Heterogenetic Cities in Premodern Southeast Asia", World Archaeology, 32, I: ıo6I2O. 
- (2004), "I $4^{\text {th }}$-Century Singapore: A Port of Trade", in John N. Miksic \& Cheryl-Ann Low Mei Gek (eds.), Early Singapore, 1300s-1819; Evidence in Maps, Text and Artefacts, 4I-54. Singapore: Singapore History Museum.

— (2005), "Between Two Mandalas: Singapore, Siam, and Java (The Benjamin Batson Memorial Lecture 2005)", ARI Working Paper Series, 51. Singapore: National University of Singapore. Milne, J. (ed.) (I990), Kwame Nkrumah: the Conakry years - his life and letters. London: Panaf. Milner, Anthony (1995), The Invention of Politics in Colonial Malaya. Cambridge: Cambridge University Press.

Moor, J.H. (I968), Notices of the Indian Archipelago and Adjacent Countries: Being a Collection of Papers Relating to Borneo, Celebes, Bali, Java, Sumatra, Nias : The Philippine Islands, Sulus, Siam, Cochin China, Malayan Peninsula, Etc. London: Cass.

Murfett, Malcolm H. et al. (I999), Between Two Oceans: A Military History of Singapore from First Settlement to Final British Withdrawal. Singapore: Oxford University Press.

Nanyang minqiao jiuxianghui linshi daibiao dahui (1926), Nanyang minqiao jiuxianghui linshi dahui baogaoshu [Report of the extraordinary meeting of the Home Salvation Campaign of the Fujian Sojourners in the South Seas). Amoy [Xiamen]: Nanyang minqiao jiuxianghui linshi daibiao dahui.

NYSP: Nan Yang Siang Pau (Chinese Daily Journal of Commerce), Singapore: Nanyang shang bao she. September I923-March I939.

Nanyang Technological University (n.d.), 'Nanyang Fellows Programme: Transforming the Next Generation of Asian Leaders'. http://www.nfp.ntu.edu.sg/index.asp

Nan'yō Dantai Rengōkai (I943), Dai Nan'yō Nenkan, dai-nichi kai [Annual of the great South Seas]. Tōkyō : Nan'yō Dantai Rengōkai.

Nan’yō Kyōkai (I9I7), 'Taiwan shibu yakuin [Membership of the Taiwan Branch]'. Nan’yō Kyōkai Zasshi 3, no. 7: 4.

— (I9I8), 'Honkai hōkoku [Association's report]', in Nan’yō Kyōkai Zasshi 4, 7: 67-73.

— (I9I9), 'Shingapōru Zhitsugyō Kyōkai sei-ro [Establishment of Singapore business association]', in Nan'yō Kyōkai Zasshi 5, I: 69-7I.

— (I934), 'Eiryō Mare ni okeru yunyū menpu jinkenpu wariate jisshi [Quota enforcement of the importation of cotton and rayon textiles to British Malaya]', Nan'yō Kyōkai Zasshi 20, 8: 96-97.

— (I939), 'Teiji sōkai jigyō hōkoku [Business report in the regular general meeting]', Nan’yō Kyōkai Zasshi 25, no. 8: I-25.

Nan’yō Kyōkai chosa-bu (1940), 'Shina jihen to Nan’yō (39)' [Chinese Incident and the South Seas (39)], Nan'yō 26, I2: І26-128.

Nan'yō Sōko (1935), Nan'yō sōko kabushiki kaisha I5-nenshi [History of the I5 years of the Southern Godown Company].

Nathan, J.E. (1922), The census of British Malaya, 1921. London, Dunstable and Watford: Waterlow Sons Limited.

National University of Singapore (2005), Singapore's Global University. Singapore: National University of Singapore.

- (2007), The NUS Difference. Singapore: National University of Singapore.

- (2008), Pursuing Excellence. Singapore: National University of Singapore.

— (2009), 'NUS Global Asia Institute'. http://www.nus.edu.sg/globalasiainstitute/

Native, A. (2002) Marita: or the folly of love, ed. Stephanie Newell. Leiden: Brill.

Newell, S. (2002) 'Introduction' to A. Native, Marita: or the folly of love. Leiden: Brill. I-37.

Nihon Naikaku Tōkei-kyoku (I996) Nihon Teikoku Tōkei Nenkan[Annual Statistics of the Japanese Empire] Vol. 35-44 (Reprint). Tōkyo: Dōyo shorin.

Nkrumah, K. (1957) Ghana: the autobiography of Kwame Nkrumah. London: Nelson.

- (I968) Dark days in Ghana. New York: International Publishers.

Nordin Hussin (1990), "Suatu Catatan Mengenai Masalah Fatwa di Johor dan Selangor: Kes Nadra I950", Jebat, I8: 335-357. 
Norris, George (1878), Singapore Thirty Years Ago: A Paper Read at a Meeting of the Mutual Improvement Society. Singapore: Straits Time Press.

O'Connor, F. (2003) The lonely voice: a study of the short story. Cork: Cork City Council.

Oguma Eiji (2003), Tan'itsu minsoku shinwa no kigen [The Myth of the Homogenous Nation]. Tōkyo: Shin-yo-sha.

Ong Chit Chung (I975), 'The 1959 Singapore General Election', Journal of Southeast Asian Studies 6 (I): 6I-86.

Pandian, Anand (2009), Crooked Stalks: Cultivating Virtue in South India. Durham and London: Duke University Press.

Pang Eng Fong (1972), Summary Report of a Re-survey of 1971 Arts, Social Science and Business Administration Graduates of the University of Singapore. Singapore: Economic Research Centre, University of Singapore.

- (I973), Employment Experiences of 1972 and 1973 University of Singapore Graduates. Singapore: Economic Research Centre, University of Singapore.

- (I974), A Report on the 1973 Singapore by Polytechnic Graduate Employment Survey. Singapore: Economic Research Centre, University of Singapore.

Pateman, C. (I989), The disorder of women: democracy, feminism, and political theory. Stanford: Stanford University Press.

Patton, A. (I989), 'Dr. John Farrell Easmon: Medical Professionalism and Colonial Racism in the Gold Coast, I856-I900.' International Journal of African Historical Studies 22 (4): 6oI636.

Pelras, Christian (1996), The Bugis (The Peoples of South-East Asia a the Pacific). Cambridge, Mass.: Blackwell Publishers.

Pickering, Jeffrey (I998), Britain's Withdrawal from East of Suez: The Politics of Retrenchment. New York: St. Martin's Press in association with Institute of Contemporary British History.

Pitt, Kuan Wah (I987), 'From Plantations to New Town: The Story of Nee Soon'. In Lim How Seng and Lim Guan Hock, eds., The Development of Nee Soon Community, I93-225. Singapore: National Archives Oral History Department.

Poh S.K., Tan Jing Quee and Koh Kay Yew (ed.) (2010), The Fajar generation: the University Socialist Club and the politics of postwar Malaya and Singapore. Petaling Jaya: SIRD.

Post, Peter (I995), 'Chinese business networks and Japanese capital in South East Asia, I880I940’, in Rajeswary Ampalavanar Brown (ed.), Chinese business enterprise in Asia, I54-I76. London and New York: Routledge.

- (2002), 'The Kwik Hoo Tong trading society of Semarang, Java: a Chinese business network in late colonial Asia', Journal of Southeast Asian Studies (January 2002): 279-296.

Proudfoot, Ian (1993), Early Malay Printed Books: A Provisional Account of Materials Published in the Singapore-Malaysia Area up to 1920, Noting Holdings in Major Public Collections. Kuala Lumpur: University of Malaya.

Purdey, Jemma (2006), Anti-Chinese Violence in Indonesia, 1996-99. Honolulu: University of Hawaỉi Press.

Raffles, Sophia (I99I), Memoir of the Life and Public Services of Sir Thomas Stamford Raffles. New York: Oxford University Press.

Ramcharan, Robin (2006), 'Singapore's Emerging Knowledge Economy: Role of Intellectual Property and its Possible Implications for Singaporean Society', The Journal of World Intellectual Property 9 (3): 316-43.

Ramlah Adam (2004), Gerakan Radikalisme di Malaysia, 1938-1965. Dewan Bahasa dan Pustaka: Kuala Lumpur. 
Reid, Anthony (1988), Southeast Asia in the Age of Commerce, vol. 1. New Haven: Yale University Press, I988.

- (2004), 'A Word from the Director', ARI News October: 2.

- (2007), "Aceh between Two Worlds: An Intersection of Southeast Asia and the Indian Ocean", in Himanshu Prabha Ray \& Edward A. Alpers (eds.), Cross Currents and community networks: the history of the Indian Ocean world, I00-I22. New York: Oxford University Press.

Robinson, William (1998), "Beyond Nation-State Paradigms: Globalization, Sociology and the Challenge of Transnational Studies", Sociological Forum, I3, 4: 56I-594.

Robson, Stuart (I995), Desawarnana (Nagarakrtagama) by Mpu Prapanca. Leiden: KITLV Press.

Rodan, Garry (1989), The Political Economy of Singapore's Industrialisation: National State and International Capital. Basingstoke: Macmillan.

Roff, William R. (1967), The Origins of Malay Nationalism. New Haven and London: Yale University Press.

Rudolph, J. (I998) Reconstructing identities: a social history of the Babas in Singapore. Aldershot: Ashgate.

Said, Edward W. (1978), Orientalism: Western Conceptions of the Orient. London: Penguin.

Sakai Kazumi (2007), “'Bunmei no shimei” to shite no Nihon no Nan’yō guntō inin-tochi: Kajyo tōji no haikei ["Civilizing mission" under the Japanese South Sea Mandate: background to the excessive rule]', in Asano Toyomi (ed.), Nan'yō Guntō no teikō.kokusai chitsujyō, 57-95. Nagoyashi: Chukyo University.

Sakano Toōru (2005), Teikō nihon to Jinroi-gakusha [Japanese Empire and Anthropologists]. Tōkyo: Keisō shobō.

Salaff, Janet W. (1988), State and Family in Singapore: Restructuring a Developing Society. Ithaca: Cornell University Press.

Salmon, Claudine (2000), 'Chinese Merchants in Southeast Asia'. In Denys Lombard and Jean Aubin eds. Asian Merchants and Businessmen in the Indian Ocean and the China Sea. New Delhi: Oxford University Press: 329-351.

Samy, A. Ma (2000), History of Tamil Journals (19 $9^{\text {th }}$ Century). Chennai: Navamani Pathippakam. Sassen, Saskia (1988), The Mobility of Labor and Capital; A Study in International Investment and Labor Flow. New York: Cambridge University Press.

- (I99I), The Global City: New York, London, Tokyo. Princeton, N.J.: Princeton University Press.

Sastri, K.A. Nilakanta (I949), "Takuapa and its Tamil Inscription Part I", Journal of the Malayan Branch of the Royal Asiatic Society, 22: 24-30.

Sato Kazuki (1997), "'Same Language, Same Race”: The Dilemma of Kanbun in Modern Japan' in Frank Dikötter (ed.), The construction of racial identities in China and Japan, II8-I35. Honululu: University of Hawaii Press.

Scabose (I90I), 'Victoria, R. I.,' Straits Chinese Magazine 5: 3.

Scott, James C. (1998), Seeing Like a State: How Certain Schemes to Improve the Human Condition have Failed. New Haven: Yale University Press.

Seah, Leander (2007), 'Hybridity, Globalization, and the Creation of a Nanyang Identity. The South Seas Society in Singapore, I940-1958'. In Journal of the South Seas Society. Singapore: South Seas Society.

Sen, Tansen (2003), Buddhism, Diplomacy and Trade: The Realignment of Sino-Indian Relations, 600-1400. Honolulu : Association for Asian Studies and University of Hawai'i Press.

Shanmugaratnam, Tharman (2006), Speech at the $5^{\text {th }}$ anniversary dinner of Asia Research Institute. University Hall, National University of Singapore, Singapore.

Shimazu Naoko (1998), Japan, Race, and Equality. London and New York: Routledge.

Shimizu Hiroshi and Hirakawa Hitoshi (1999), Japan and Singapore in the world economy: Japan's Economic Advance into Singapore, 1870-1965. London and New York: Routledge. 
Shingapōru shōhin chinretsu-kan (I919), 'Shingapōru ni okeru hainichi-bōdō jiken no shinsō [The truth of anti-Japanese riots in Singapore]', Nan'yō Kyōkai Zasshi 5, no. 9: 39-49.

Shingapōru shōhin chinretsu-sho (I93I), 'Eiryō Marai ichiba ni okeru gomu kiyanbasu kutsu no jukyū jōkyō' [Conditions of demand and supply of rubber-soled canvas shoes in British Malayan markets], ' Nan’yō Kyōkai Zasshi I7, no. 5: 47-52.

Shingapōru shōhin chinretsu-sho (I932a), 'Eiryō Marai ni okeru hakimono, ichi [Footwear in British Malaya, I]', Nan'yō Kyōkai Zasshi ı, no. 3: 8-33.

— (I932b), 'Eiryō Marai ni okeru hakimono, ni [Footwear in British Malaya, II]', Nan'yō Kүōkai Zasshi i8, no. 4: I6-45.

- (I933a), 'Eiryō Marai ni okeru honpō sen'i-kōgyō-hin, san [Japanese textile manufactures in Singapore III]', Nan'yō Kyökai Zasshi 19, no.9: 45-63.

— (I933b), 'Eiryō Marai ni okeru honpō sen'i-kōgyō-hin, shi [Japanese textile manufactures in Singapore IV],' Nan'yō Kyōkai Zasshi 19, no. I0: 27-39.

- (I933C), 'Shingapōru ni okeru honpō sen'i-kōgyō-hin [Japanese textile manufactures in Singapore]', Nan'yō Kyōkai Zasshi 19, no. II: 28-42.

- (1933d), 'Shingapōru men-taoru shikyō [Market reports of cotton towels in Singapore],' Nan’yō Kyōkai Zasshi I9, no. II: IOI-IO4.

- (1933e), 'Shingapōru shijou ni okeru honpō jinken no chìi to sono shōrai', Nan'yō Kyōkai Zasshi I9, no. II: I03-108.

— (I936), 'Eiryō Marai ni okeru jinkenpu', Nan’yō Kyōkai Zasshi 22, no. 2: 22-37.

Shingapōru Sangyōkan (I94I), 'Eiryō Marai orimono seihin ichiba tenbō [Prospects of textile markets in British Malaya]', Nan'yō 27, no. 4: 60-63.

Sidel, John T. (2006), Riots, Pogroms, Jihad: Religious Violence in Indonesia. Ithaca: Cornell University Press.

Sidhu, Ravinder (2006), 'How to Assemble a Knowledge Economy. Singapore's Transnational Education Project', Perspectives in Education 24, 4: 45-56.

Sim, Victor (ed.) (I950), Biographies of prominent Chinese in Singapore. Singapore: Nan Kok Publication Company.

Singapore Ann Kway Association 新加坡安溪会馆 (1974), Xinjiapo Anxi Huiguan Jinxi Jinian Tekan, 1922-1972 新加坡安溪会馆金禧纪念特刊,I922-I972 (50th anniversary souvenir magazine of the Ann Kway Association), Singapore: Singapore Ann Kway Association.

- (1992), Xinjiapo Anxi Huiguan Chengli Qishi Zhounian Ji Diyijie Shijie Anxi Xiangqin Lianyihui Jinian Tekan, 1922-1992 新加坡安溪会馆成立七十周年暨第一届世界安溪乡亲联谊会 纪念特刊 I922-1992 (70th anniversary of the Singapore Ann Kway Association and the first World Ann Kway Convention), Singapore: Singapore Ann Kway Association.

Singapore Economic Development Board (I999), A Knowledge-based Economy. Singapore: Economic Development Board.

Singapore Economic Review Committee (2003), New Challenges, Fresh Goals - Towards a Dynamic Global City: Report of the Economic Review Committee. Singapore: Ministry of Trade and Industry.

Singapore InfoComm Development Authority (2008), 'About Us: About iN2015', iDA Singapore. http://www.ida.gov.sg/About\%20us/20070903I45526.aspx

— (2009), 'Facts \& Figures: Singapore Infocomm Statistics at a Glance', iDA Singapore. http:// www.ida.gov.sg/Publications/2006II30I7520I.aspx

Singapore Management University (n.d.), An Unconventional MBA for Unconventional Minds: The SMU MBA. Singapore: Lee Kong Chian School of Business, Singapore Management University.

Singapore Piece-goods Traders Guild (1994) Xinjiapo buhang shangwuju qingzhu chengli 85 zhounian jinian tekan [Souvenir of the 85 annual of the Singapore piece goods traders guild]. Singapore: Singapore Piece-Goods Traders' Guild. 
Singapore (I975), Master Plan: Third Review, 1975. Singapore: Planning Department, Ministry of National Development.

Singapore. Ministry of Education. Technical Education Department (1969), One Year of Technical Education April 1968-March 1969. Singapore: Ministry of Education, Technical Education Department.

Singapore. Ministry of Labour (I977a), Employment Act: Law and Practice. Singapore: Ministry of Labour.

Singapore. Ministry of Labour (1977b), Industrial Relations Act: Law and Practice. Singapore: Ministry of Labour.

Singapore. Radio Corporation of Singapore (I967), Audio recording titled 'Interview With Manual Pillay, Economic Development Board'. 6 December.

Singapore. Radio Corporation of Singapore (I968), Audio recording titled 'S. Rajaratnam At Graduation Ceremony Of ist Group Of Trainees For Redundant Base Civilian Workers'. 29 July.

Singapore. Radio Corporation of Singapore (I968), Audio recording titled 'Conversion Of Naval Base - Swan Hunter Group'. I8 June.

Singapore. Technical Education Department (1973), Technical Education and Industrial Training in Singapore: A Brief Review of the Achievements of the Technical Education Department, 196873. Singapore: Technical Education Department.

Singapore. University of Singapore, Economic Research Centre (I976), The Employment Experiences of Post-secondary and University Graduates in Singapore, 1971-1975. Singapore: Economic Research Centre, University of Singapore.

Singapore. University of Singapore, Economic Research Centre (1980), The Employment Experiences of 1969-1971 Vocational Graduates. Singapore: Economic Research Centre, University of Singapore.

Slaughter, Sheila and Gary Rhoades (2004), Academic capitalism and the new economy. Baltimore: Johns Hopkins University Press.

Smail, John R. (I96I), 'On the Possibilities of an Autonomous History of Southeast Asia', Journal of Southeast Asian History 2, 2: 72-102.

Smith, Joseph B. (1976), Portrait of a Cold Warrior. New York: Putnam's.

So, Kee Long (I998), "Dissolving Hegemony or Changing Trade Pattern? Images of Srivijaya in the Chinese Sources of the Twelfth and Thirteenth Centuries", JSEAS, 29, 2: 295-308.

Soh P.T. (I907), 'Concerning our girls,' Straits Chinese Magazine II: I39-I43.

Solomon, Eli (2008), Snakes and Devils. Singapore: Marshall Cavendish Editions.

Song O.S. (1899), 'Are the Straits Chinese British subjects?' Straits Chinese Magazine 3: 6I-67.

Song Ong Siang (1967), One Hundred Years' History of the Chinese in Singapore. Kuala Lumpur: University of Malaysia Press.

Southwood, Peter (I99I), Disarming Military Industries: Turning an Outbreak of Peace into an Enduring Legacy. Basingstoke: Macmillan.

Spencer, George (I976), “The Politics of Plunder: The Cholas in Eleventh-Century Ceylon", Journal of Asian Studies, 35, 3: 405-4I9.

Stern, Fritz (ed.) (I972), The Varieties of History from Voltaire to the Present. New York: Vintage Books.

Stockwell, Anthony (I986), "Imperial security and Moslem militancy, with special reference to the Hertogh Riots in Singapore”, JSEAS, 7, 2: 322-335.

Stockwell, Sarah (2008), 'Ends of Empire'. In Sarah Stockwell ed. The British Empire: Themes and Perspectives. Malden, MA: Blackwell Publishers: $269-93$.

Straits Settlements (I9I9), Straits Settlements Government Gazettes, Supplement to 1919: annual report on the Straits Settlement police force and on the state of crime for the year 1919, 'secret societies, etc.' Singapore: Straits Settlement.

Straits Settlements (I934), Straits Settlement Government Gazettes, 1934. Singapore: Straits Settlements.

Su, Jiqing 穌繼慶 (I98I), Daoyi zhilue jiaoshi 島夷志略校釋. Beijing: Zhonghua shuju. 
Subramaniam, Sunjay (I999), “Connected Histories: Notes Towards a Reconfiguration of Early Modern Eurasia”, in Victor Lieberman (ed.), Beyond Binary Histories: Re-Imagining Eurasia to c. 1830, 289-316. Ann Arbor: Michigan University Press.

Sun, Jian 孙健 (I992), Zhonghua Renmin Gonghe Guo Jingji Shi (1949-90 Niandai Chu) 中华人民共和国经济史 (I949-90年代初) (Economic history of the People's Republic of China from I949 to the early I990s), Beijing: Zhongguo Renmin Daxue Chubanshe.

Tai, Jackson (2006), 'CEO's Report: Committed to Strengthening our Franchise in Asia', DBS Group Holdings Ltd Annual Report, I4-22. Singapore: DBS Bank.

Taiwan Dai-Ajia Kyōkai (I938), Nanshi Sōkō chōsa hōkoku-sho. Taipei: Taiwan Dai-Ajia Kyōkai.

Taiwan Ginkō (I9I4), Nan'yō ni okeru kakyō: Shina ijyōmin [Overseas Chinese in the South Seas: emigrants from China]. Taipei: Taiwan Ginkō.

Taiwan Ginkō (I939), Taiwan Ginkō shijōnenshi [40 Years of the Bank of Taiwan]. Taipei: Taiwan Ginkō.

Taiwan Takushoku Kabushiki Kaisha (I942) Nan’yō Kakyō to sono taisaku [South Seas Chinese and the strategies to deal with them]. Taipei: Taiwan Takushoku Kabushiki Kaisha.

Taiwan Sōtokufu (I904), Taiwan Kanshō kiji v. 4, no. 4 [Old Customs in Taiwan, v. 4, no. 4]. Taipei: Taiwan Sōtokufu [Reprinted and translated into Chinese by the Nantian chubanshe, I988].

Taiwan Sōtokufu gaiji-bu (I943), Kakyō keizai jijyō, Taiwan Sōtōkufu gaiji chōsa No. 133 [Economic situations of overseas Chinese, Foreign affairs survey No. I33. Office of the Governor-in-General, Taiwan]. Taipei: Kōmyōsha shōkai.

Taiwan Sōtokufu shokusan-kyoku tokusan-ka (I935), Nettai sangyō chōsa-sho: Taiwan cha ni kansuru chōsa [Report of tropical industry survey: survey on Taiwan tea]. Taipei: Taiwan Sōtokufu shokusan-kyoku tokusan-ka.

Taiwan Tea Exporters' Association (1965), The Historical Brevities of Taiwan Tea Export, 18651965, Taipei: Taiwan Tea Exporters' Association.

Tan Chor Chuan (2008), 'Continuity and Transformation', State of the University Address. National University of Singapore, Singapore. http://www.nus.edu.sg/soua/2008/ SoUA_IO_Oct_o8.pdf

Tan E.L. (I9I8), 'National character and how it is acquired,' S.C.L.A. Recorder I(4): 7.

Tan Jake Hooi (I972), Urbanisation Planning and National Development Planning in Singapore. New York: Southeast Asia Development Advisory Group, Asia Society.

Tan Keong Choon (I98I) OHC Synopsis Report No. 52. Singapore: National Archives.

Tan Pheng Theng (I970), The Economic Development of Singapore and the Labour Law Changes of I968: A Case Study. Unpublished LLM Thesis. Harvard Law School, Harvard University.

Tan T.S. (1897), 'Some genuine Chinese authors,' Straits Chinese Magazine r: 63, 64.

Tan Yew Soon and Soh Yew Peng (I994), The Development of Singapore's Modern Media Industry. Singapore: Times Academic Press.

Tan, Tony (I998), 'The Singapore Economy in the 2Ist Century', The Chinese High Lecture I998. Chinese High School, Singapore. Singapore: Ministry of Information and the Arts.

Tanaka, Stephen (I993) Japan's Orient: Rendering Pasts into History. London and New York: University of California Press.

Tarling, Nicholas (I993), The Fall of Imperial Britain in South-east Asia. Singapore: Oxford University Press.

Tay, Alice Erh Soon (1962), 'The Chinese in South-East Asia', Race, 4 (I): 34-48.

Teo Chee Hean (2000), 'Education Towards the 2Ist Century: Singapore's Universities of Tomorrow, Speech at the Alumni International Singapore Lecture, Singapore, Jan 7, 2000. http://www.moe.gov.sg/media/speeches/2000/spioor2000.htm

- (2003), Speech at the official launch of the Asia Research Institute. Pan Pacific Hotel, Singapore. Singapore: Ministry of Information, Communications and the Arts. 
Thomson, John Turnbull (I99I), Glimpses into Life in Malayan Lands. Singapore: Oxford University Press.

Tibbetts, G.R. (1979), A Study of the Arabic Texts Containing Material on Southeast Asia. Leiden: Brill.

Tilly, Charles (1985), 'War Making and State Making as Organized Crime', in Peter Evans, Dietrich Rueschemeyer, \& Theda Skocpol (ed.), Bringing the State Back In, I69-187. Cambridge: Cambridge University Press.

— (I995), "To Explain Political Processes", The American Journal of Sociology, Ioo, 6: I594-1610.

Tōgō An (I9I9), 'Nan’yō Kyōkai no genkyō to sono shōrai [Nan’yō Kyōjai's current situation and its future]', Nan'yō Kyökai Zasshi 5, no. 6: I05-I16.

Toohey, Brian (1989), Oyster: The Story of the Australian Secret Intelligence Service. Victoria, Australia: William Heinemann.

Tosh, J. (200), A man's place: masculinity and the middle-class home in Victorian England. New Haven: Yale University Press.

Trocki, Carl (1979), Prince of Pirates: The Temenggongs and the Development of Johor and Singapore, 1784-1885. Singapore: Singapore University Press.

- (1990), Opium and Empire: Chinese Society in Colonial Singapore, 1800-1910. Ithaca, N.Y.: Cornell University Press.

- (2007), Prince of Pirates: The Temenggong and the Development of Johor and Singapore 17841885 , Singapore: NUS Press.

Tschacher, Torsten (2009), 'Circulating Islam: Understanding Convergence and Divergence in the Islamic Traditions of Ma'bar and Nusantara.' In R. Michael Feener and Terenjit Sevea (eds.), Islamic Connections: Muslims Societies in South and Southeast Asia, 48-67. Singapore: Institute of Southeast Asian Studies.

Tu Chaōyan (I993), Riban diguozhupi xia de Taiwan [Taiwan under Japanese Imperialism]. Taipei: Renjian chubanshe (Translated from Japanese to Chinese by Li Mingjun).

$\mathrm{Tu}$, Youxiang 屠友祥 (1996), Zhou Qufei 周去非: Lingwai daida 嶺外代答. Shanghai: Yuandong chubanshe.

Tunku Abdul Rahman Putra (1977), Looking Back: Monday Musings and Memories, Kuala Lumpur, Malaysia: Pustaka Antara.

Turnbull, C. Mary (1972), The Straits Settlements, 1826-67: Indian Presidency to Crown Colony. London: Athlone Press.

— (1989), A History of Singapore, 1819-1988. 2nd edn. Singapore: Oxford University Press.

— (2009), A History of Modern Singapore 1819-2005. Singapore: NUS Press.

Ukers, W.H. (1935), All about Tea, two volumes, first published by the Tea \& Coffee Trade Journal in New York in I935, Westport: Hyperion Press.

Unekawa Shizuo (1927), Kaiun kōkokushi [The history of maritime transportation and national prosperity]. Ōsaka : Kaiji Ihōsha.

Vella, Walter (1978), Chaiyo! King Vajiravudh and the Development of Thai Nationalism, assisted by Dorothy B Vella. Honolulu: University Press of Hawaii.

Wales, H.G. Quaritch (I940), "Archaeological Researches on Ancient Indian Colonization", Journal of the Malayan Branch of the Royal Asiatic Society, I8: 8-IO.

Wallerstein, Immanuel (I974), The Modern World System. New York: Academic Press.

Wang Gungwu (198I), Community and Nation: Essays on Southeast Asia and the Chinese. Singapore: Heinemann Education Books (Asia) Ltd.

- (2003), Only Connect! Sino-Malay Encounters. Singapore: Eastern Universities Press.

- (2005), 'Within and Without: Chinese Writers Overseas'. In Journal of Chinese Overseas, I-I5. Singapore: Singapore University Press. 
Wang Shiqing (2008), 'Taiwan tuozhi zhushi huishi zhi tudi touzi yu jingying - yi zongdufu chuzi zhi sheyoudi wei zhongxin [Land investment and management of the Taiwan Colonisation Company. study of the investment by the Office of the Governor-General, Taiwan]. In Guoshiguan Taiwan wenxianguang (ed.). Taiwan tuozhi zhushi huishe dangan lunwenji [Essays on archives of the Taiwan Colonisation Company], I-55. Nantou, Taiwan: Taiwan Wenxianguan.

Wang, Yunwu (1936), Ma Duanlin: Wenxian tongkao. Shanghai: Shangwu yinshuguan.

Watanabe Kaoru (I934), 'Kaigai ni okeru shōgyō teki jiban no kaitaku to kokka kan’nen', Nan’yō Kyōkai Zasshi Vol. 20, no. 4: 15-26.

Wheatley, Paul (I954), 'Land Use in the Vicinity of Singapore in the Eighteen-Thirties', Malayan journal of tropical geography, 2: p. 63-66.

Wee, C.J. W.-L. (I999), 'The Vanquished: Lim Chin Siong and a progressivist national narrative', in Lam Peng Er and Kevin YL Tan (ed.), Lee's lieutenants: Singapore's old guard, 169-90. NSW, Australia: Allen \& Unwin.

Weiner, Michael (I995), 'Discourse of Race, Nation, and Empire in Pre-I945 Japan', Ethnic and Racial Studies I8, no. 3: 433-456.

Westad, Odd Arne (2005), The Global Cold War: Third World Interventions and the Making of Our Times. New York: Cambridge University Press.

Winstedt, R.O. (1926), "Gold Ornaments Dug up at Fort Canning, Singapore”, Journal of the Malayan Branch of the Royal Asiatic Society, 6, 4: I-4.

Wisseman-Christie, Jan (I998), "The Medieval Tamil-Language Inscriptions in Southeast Asia and China", Journal of Southeast Asia Studies, 29, 2: 239-268.

Wolf, Eric R. (1982), Europe and the People Without History. Berkeley: University California Press.

Wolters, O.W. (1958), “Tambralingga” Bulletin of the School of Oriental and African Studies, 2I, 3: $587-607$.

- (I967), Early Indonesian Commerce: A Study of the Origins of Srivijaya. Ithaca: Cornell University Press.

- (I970), The Fall of Srivijaya in Malay History. Kuala Lumpur: Oxford University Press.

- (I983), "A Few and Miscellaneous Pi-Chi Jottings on Early Indonesia" Indonesia, 34: 49-65.

- (I986), "Restudying Some Chinese Writings on Sriwijaya”, Indonesia, 42: I-42.

- (I999), History, Culture and Region in Southeast Asian Perspectives. Singapore: Institute of Southeast Asian Studies, I999.

Wong, Lin Ken (I960), 'The Trade of Singapore, I8I9-69', Journal of the Malayan Branch, Royal Asiatic Society,33, 4: I-3I5.

- (I978), 'Singapore: Its Growth as an Entrepot Port I8I9-I94I', Journal of Southeast Asian Studies 9 (I): 50-84.

- (1981), "A View of Our Past”, in Lee Yik \& Chang Chin Chiang (eds.) Singapore in Pictures, 4-26. Singapore: Sin Chew Jit Poh \& Ministry of Culture.

Wong, Chin Soon (1987), 'The Hainanese village that disappeared'. In Lim How Seng and Lim Guan Hock, eds., The Development of Nee Soon Community, 87-90. Singapore: National Archives Oral History Department.

Wong, Yoon Wah (200I), Post-Colonial Chinese Literatures: Thoughts on the Local and Multi-cultural. Taipei: Wen Shi Ze Publishers.

Wurtzburg, Charles Edward (I954), Raffles of the Eastern Isles: (by) C.E.Wurtzburg. London: Hodder \& Stoughton.

Xiamen huaqiao zhi bianzuan weiyuanhui (ed.) (I99I), Xiamen huaqiao zhi [History of overseas Chinese from Xiamen]. Xiamen: Lujiang chubanshe.

Xiamen Shi Dang'an Ju 厦门市档案局 and Xiamen Shi Dang'an Guan 厦门市档案馆 (I997), Jindai Xiamen Jingji Dang'an Ziliao 近代厦门经济档案资料, Xiamen: Xiamen Daxue Chubanshe. 
Xie, Minggan 谢明干 and Luo Yuanming 罗元明 (eds.) (I990), Zhongguo Jingii Fazhan Sishi Nian 中国经济发展 40 年 (Forty years of economic development in China), Beijing: Renmin Chubanshe.

Xu Jiaozheng ed. (1965), Who's Who in South East Asia. Singapore: Xu Jiaozheng.

Yamaoka Yuka (I995), Nakasaki Kashô keiei no shiteki kenkyû: kindai chûgoku shônin no keiei to chôbo [Business history of Chinese merchants in Nagasaki: management and accounting of Modern Chinese businesses]. Kyoto: Mineruva Shobô.

Yano Tōru (I975), Nanshin no keifu [Genealogy of Japan’s Southward Advance]. Tōkyo: Chuoōu kōron-sha.

Yao, Nan (I984), 'Han Wai Toon and Han Rambutan Orchard'. Xin Yun Ye Yi Ji (Chronicles of Starry Clouds and Coconut Rain), 75-80. Singapore: SNPL Book Publications Department.

Yap, Sonny Yap, Lim, Richard and Leong Weng Kam (2009), Men in White: The Untold Story of Singapore's Ruling Political Party. Singapore: Singapore Press Holdings Limited.

Yen Ch'ing-hwang (I989), 'The Response of the Overseas Chinese in Singapore and Malaya to the Tsinan [Jinan] Incident, I928', in Ng Lun Ngai-ha and Chang Chak Yan (eds.) Overseas Chinese in Asia between the Two World Wars, 263-282. Hong Kong: Overseas Chinese Archives and Centre for Contemporary Asian Studies, The Chinese University of Hong Kong.

Yeo Kim Wah (I973), Political Development in Singapore. Singapore: Singapore University Press.

Yeo Kim Wah \& Albert Lau (I99I), 'From Colonialism to Independence, I945-I965,' in Ernest Chew and Edwin Lee (ed.), A History of Singapore, II7-I53. Singapore: Oxford University Press.

Yeo, F. Teng Yang (I970), Singapore: State of the Economy: 1970 Mid-year Report. Singapore: Economics Section, Economic Development Division, Ministry of Finance.

Yeo, George (I997), Speech at the Official Opening of the East Asian Institute. Singapore: Ministry of Information and the Arts.

Yeung, Wei-Jun Jean (2009), 'ARI Special Feature I', ARI News March: 8.

Yeung, Yue-Man \& Lo, Fu-Chen (I996), "Global Restructuring and the Emerging Urban Corridors in Pacific Asia”, in Fu-Chen Lo \& Yue-Man Yueng (eds.), Emerging World Cities in Pacific Asia, I7-47. New York: United National University Press.

Yong Ching-fatt (1987), Tan Kah Kee: The Making of an Overseas Chinese Legend. Singapore and New York: Oxford University Press.

Yorozu Chōhō (I9I8), 'Kakyō Ginkō setsuretsu no gi [Proposal for establishing an overseas Chinese bank]', in Nan'yō Kyōkai Zasshi 4, no. 3: 74-76.

Young, Louise (I999), Japan's Total Empire: Manchuria and the Culture of Wartime Imperialism. Berkeley, CA: University of California Press.

Yu, Lizhen 余丽珍 (I99I), Xiamen Huaqiao Zhi 厦门华侨志 (Overseas Chinese from Xiamen), Xiamen: Lujiang Chubanshe.

Yvan, Melchior (18550, Six Months among the Malays and a Year in China. London: James Blackwood.

Zhang Shuicun 张水存 (I997), 'Zhang Yuanmei Chahang Jingying Shi' 张源美茶行经营史 (An economic history of Zhang Yuan Mei Tea Merchant), in Xiamen Shi Zhengxie Wenshi Ziliao Weiyuanhui 厦门市政协文史资料委员会 and Xiamen Zongshang Hui 厦门总商会 (eds), Xiamen Gongshang Shishi 厦门工商史事 (Articles on the history of Xiamen industry and commerce), 2I7-222. Xiamen: Xiamen Daxue Chubanshe.

Zhongguo Chaye Gufen Youxian Gongsi 中国茶叶股份有限公司 and Zhonghua Charen Lianyihui 中国茶人联谊会 (200I), Zhonghua Chaye Wuqian Nian 中华茶叶五千年 (Five thousand years of Chinese tea), Beijing: Renmin Chubanshe.

Zhongguo Minzhu Jianguohui Fujian Sheng Weiyuanhui 中国民主建国会福建省委员会 and Fujian Sheng Gongshangye Lianhehui 福建省工商业联合会 (eds) (I986), Fujian Gongshang 
Shiliao 福建工商史料 (Articles on the history of Fujian industry and commerce), volume I, Fuzhou: Zhongguo Minzhu Jianguohui Fujian Sheng Weiyuanhui and Fujian Sheng Gongshangye Lianhehui.

Zhongguo Shehui Kexue Yuan 中国社会科学院 and Zhongyang Dang'an Guan 中央档案馆 (I99I), 1949-1952 Zhonghua Renmin Gonghe Guo Jingji Dang'an Ziliao Xuanbian - Nongye Juan I949-I952 中华人民共和国经济档案资料选编-农业卷 (Selections from the Economic Archives of the People's Republic of China on agriculture, I949-I952), Beijing: Shehui Kexue Wenxian Chubanshe.

\section{Other Reference Materials}

'An Allegory: The Sorrowing Mother' (1898), Gold Coast Aborigines March I2: 3.

'By the Way' (1899), Gold Coast Aborigines May 27: 3.

'Editorial: The Race Question in Colonial Administration' (I905a) Straits Chinese Magazine 9: $\mathrm{I}-6$.

'Editorial: The Need for an Asiatic Daily' (I905b), Straits Chinese Magazine 9: 4I-42.

'Her Late Majesty the Queen Empress' (I9OI), Straits Chinese Magazine 5: I-2.

'Journalism on the Gold Coast' (1899), Gold Coast Leader May 27: 4-5.

'News and Notes' (I899), Straits Chinese Magazine 3: 68-72.

'Our Programme' (1897), Straits Chinese Magazine I: I-2.

'Sketches of the lives and labours of our great men,' (1898b), Gold Coast Aborigines March 5: 3. 'Sketches of the lives and labours of our great men' (1898a), Gold Coast Aborigines January 8: 3-4.

'The Chinaman in Pahang' (I898), Straits Chinese Magazine 2: 37-38.

'The Fanti Land' (I902), Gold Coast Leader November 29: 4.

'The Gold Coast Aborigines' (I898) Gold Coast Aborigines January I: 2-3.

'The Travels of Chang Ching Chong' (1898), Straits Chinese Magazine 2: 13-15, 64-67, 84-88, I39-I44.

'What's in a Name?' (I902), Gold Coast Leader, July 5: 2-3.

'William Addo, Esq. Barrister at Law' (ı896), Gold Coast Independent, July iı: 2. 


\section{CaS Publications Series}

\section{Monographs}

Marleen Dieleman

The Rhythm of Strategy. A Corporate Biography of the Salim Group of Indonesia

Monographs I

2007 (ISBN 9789053560334 )

Sam Wong

Exploring 'Unseen' Social Capital in Community Participation. Everyday

Lives of Poor Mainland Chinese Migrants in Hong Kong

Monographs 2

2007 (ISBN 978905356034 I)

Diah Ariani Arimbi

Reading Contemporary Indonesian Muslim Women Writers. Representation, Identity and Religion of Muslim Women in Indonesian Fiction

Monographs 3

2009 (ISBN 978908964089 5)

Euis Nurlaelawati

Modernization, Tradition and Identity. The Kompilasi Hukum Islam and

Legal Practice in the Indonesian Religious Courts

Monographs 4

20I0 (ISBN 978908964 o88 8)

\section{Edited Volumes}

Sebastian Bersick, Wim Stokhof and Paul van der Velde (eds.)

Multiregionalism and Multilateralism. Asian-European Relations in a Global Context

Edited Volumes I

2006 (ISBN 978905356929 o) 
Khun Eng Kuah-Pearce (ed.)

Chinese Women and the Cyberspace

Edited Volumes 2

2008 (ISBN 978905356 75I 7)

Milan J. Titus and Paul P.M. Burgers (eds.)

Rural Livelihoods, Resources and Coping with Crisis in Indonesia. A Comparative Study

Edited Volumes 3

2008 (ISBN 978908964055 ㅇ)

Marianne Hulsbosch, Elizabeth Bedford and Martha Chaiklin (eds.)

Asian Material Culture

Edited Volumes 4

2009 (ISBN 978908964090 I)

Hans Hägerdal (ed.)

Responding to the West. Essays on Colonial Domination and Asian Agency

Edited Volumes 5

2009 (ISBN 9789089640932 )

Derek Heng and Syed Muhd Khairudin Aljunied (eds.)

Reframing Singapore. Memory - Identity - Trans-Regionalism

Edited Volumes 6

2009 (ISBN 9789089640949 )

Friederike Assandri and Dora Martins (eds.)

From Early Tang Court Debates to China's Peaceful Rise

Edited Volumes 7

2009 (ISBN 978905356795 I)

Erich Kolig, Vivienne SM. Angeles and Sam Wong (eds.)

Identity in Crossroad Civilisations. Ethnicity, Nationalism and Globalism in Asia

Edited Volumes 8

2009 (ISBN 978908964 I27 4)

Khun Eng Kuah-Pearce and Gilles Guiheux (eds.)

Social Movements in China and Hong Kong. The Expansion of Protest Space

Edited Volumes 9

2009 (ISBN 978908964 I3I I) 
Huhua Cao (ed.)

Ethnic Minorities and Regional Development in Asia. Reality and Challenges

Edited Volumes IO

2009 (ISBN 978908964 O9I 8)

M. Parvizi Amineh (ed.)

State, Society and International Relations in Asia. Reality and Challenges

Edited Volumes II

2010 (ISBN 978905356794 4)

Philip F. Williams (ed.)

Asian Literary Voices. From Marginal to Mainstream

Edited Volumes I2

2010 (ISBN 978908964092 5)

Philip Hirsch and Nicholas Tapp (eds.)

Tracks and Traces. Thailand and the Work of Andrew Turton

Edited Volumes 13

20I0 (ISBN 978908964249 3)

Derek Heng and Syed Muhd Khairudin Aljunied (eds.)

Singapore in Global History

Edited Volumes I4

2OII (ISBN 978908964324 7) 
(CAS) Publications Series

Edited Volumes 14

Derek Heng is Assistant Professor at the History Department, Ohio State University. He specialises in pre-modern Sino-Southeast Asian economic interaction and early Southeast Asian state formation. Syed Muhd Khairudin Aljunied is Assistant Professor at the Malay Studies Department, National University of Singapore. His research encompasses colonial history, the history of ideas and social identities.

Singapore in Global History brings together scholars working in the fields of political science, international relations, history, sociology, literature, art history and architecture to explore ways in which Singapore's history could be looked upon from a global perspective. The volume's papers make a collective attempt at arguing, often in radically novel fashion, that Singapore can be conceived both as core and periphery, and that the logic of the post-colonial nation-narrative, which attributes Singapore's success primarily to the roles of big men and strong government, are inadequate.

This volume locates Singapore as a central space between the major termini of maritime Asia and the world, and articulates the island as a strategic location where the global processes find their nesting place, where its society is fundamentally affected by these processes, and where the roots of global transformative processes eventually emanate to far reaching parts of a globalising world.

This path-breaking and multidisciplinary collection of essays broadens the horizons of, and suggests new ways of approaching, Singapore history, from the fourteenth century to the present, by placing the island and its people in a larger comparative and global framework.

Craig A. Lockard, Rosenberg Professor, University of Wisconsin-Green Bay

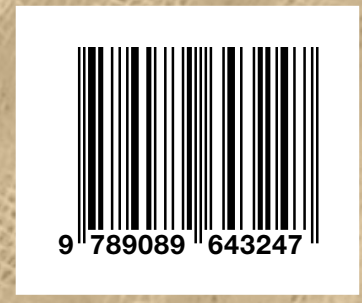

